\title{
Expedition 309/312 summary ${ }^{1}$
}

\author{
Expedition 309/312 Scientists ${ }^{2}$
}

\section{Chapter contents}

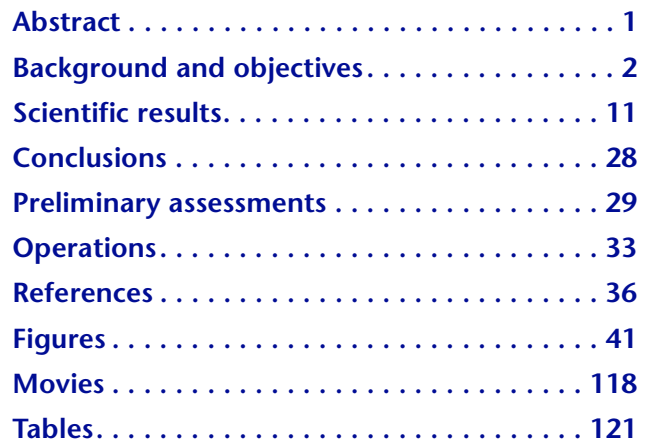

${ }^{1}$ Expedition 309/312 Scientists, 2006. Expedition 309/312 summary. In Teagle, D.A.H., Alt, J.C., Umino, S., Miyashita, S., Banerjee, N.R., Wilson, D.S., and the Expedition 309/312 Scientists. Proc. IODP, 309/312: Washington, DC (Integrated Ocean Drilling Program Management International, Inc.), 1-127. doi:10.2204/ iodp.proc.309312.101.2006

'Expedition 309/312 Scientists' addresses.

\section{Abstract}

The Superfast Spreading Rate Crust mission is a multicruise program to drill, for the first time, a complete section of the upper oceanic crust from the extrusive lavas, through the dikes, and into the underlying gabbros. Hole $1256 \mathrm{D}$ was initiated during Ocean Drilling Program Leg 206 in the eastern equatorial Pacific and is drilled into $15 \mathrm{Ma}$ crust that formed at the East Pacific Rise during a period of superfast spreading $(>200 \mathrm{~mm} / \mathrm{y})$. This site is chosen to exploit the inverse relationship between spreading rate and the depth to axial low-velocity zones, thought to be magma chambers now frozen as gabbros, observed from seismic experiments. During Integrated Ocean Drilling Program (IODP) Expedition 309, Hole 1256D was deepened to a total depth of 1255 meters below seafloor (mbsf) (1005 m subbasement), having penetrated $>800 \mathrm{~m}$ of extrusive normal mid-ocean-ridge basalt, and entered the sheeted dike complex. IODP Expedition 312 returned to Hole $1256 \mathrm{D}$ and deepened it to $1507.1 \mathrm{mbsf}$. The hole now extends through the $346 \mathrm{~m}$ sheeted dike complex and $100.5 \mathrm{~m}$ into the upper portions of the plutonic section. The uppermost crust at Site 1256 comprises a $>74 \mathrm{~m}$ thick ponded lava overlying massive, sheet, and minor pillow flows, some of which exhibit inflation structures requiring eruption onto a subhorizontal surface. This suggests a total thickness of off-axis lavas of $284 \mathrm{~m}$. Sheet and massive lava flows make up the remaining extrusive section (534-1004 mbsf) above subvertical cataclastic zones, intrusive contacts, and mineralized breccias denoting a lithologic transition zone. Below 1061 mbsf, massive basalts, some with doleritic textures, dominate the sheeted dikes, which exhibit increased thermal conductivity and $P$-wave velocity. Numerous subvertical dikes, commonly with brecciated and mineralized chilled margins, crosscut the sheeted dikes. The upper dikes ( $<1255 \mathrm{mbsf})$ contain greenschist-facies minerals, actinolite becomes abundant below $\sim 1300$ mbsf, and hornblende and secondary plagioclase are present below $\sim 1350 \mathrm{mbsf}$, reflecting a steep thermal gradient in the dikes. Superimposed on this is recrystallization of the lowermost $\sim 60 \mathrm{~m}$ of dikes to granoblastic textures as the result of intrusion of underlying gabbros. An upper gabbroic body intrudes the sheeted dikes at $1406.6 \mathrm{mbsf}$ and is separated from a lower gabbroic body at 1483-1507.1 mbsf by an intervening metamorphosed dike screen. Gabbroic rocks are highly altered and fine to coarse grained (mostly medium grained), range from gabbro to oxide gabbro and gabbronorite, and include differentiated rocks 
(trondjhemite and quartz-rich oxide diorite). The base of the section contains a gabbronorite of uncertain origin (intrusive gabbronorite or metamorphosed dike) and is cut by a late basalt dike. Physical properties change downward across the dike/gabbro contact (increased porosity and decreased velocity and density).

\section{Background and objectives}

More than $60 \%$ of the Earth is covered by oceanic crust formed at the mid-ocean ridges, all of which formed within the last 200 m.y. The formation of new oceanic crust at ridge axes and reincorporation of aged crust into the mantle or its accretion onto continental margins at subduction zones are perhaps the most fundamental components of the plate tectonic cycle. These processes control the physiography of the Earth and the chemical and thermal evolution of the crust and mantle.

Accretion of oceanic crust at mid-ocean ridges from magmas passively upwelled during partial melting of decompressed mantle peridotite is the dominant process of thermal and chemical transfer from the Earth's interior to the crust, overlying oceans, and atmosphere. Conduction and hydrothermal advection of heat at constructive plate boundaries through the oceanic lithosphere and as it matures on the ridge flanks are the major mechanisms for heat loss from the interior of the planet. Such hydrothermal interactions influence the chemistry of many elements (e.g., $\mathrm{Mg}, \mathrm{Sr}, \mathrm{U}$, and $\mathrm{K}$ ) in the oceans at a similar magnitude to the inputs from rivers draining the continents. Chemical exchange of seawater with the ocean crust leads to major changes in the chemical composition and physical properties of oceanic basement, which, through subduction, influence the composition and heterogeneity of the mantle and the melting and constructional processes occurring in arcs.

Recently, the upper oceanic crust has been shown to contain habitats for microorganisms. Microbes colonize fractures in glassy basaltic rocks, extracting energy and/or nutrients from the glass by dissolving it, leaving behind biomarkers that reveal their former presence. The temperature and depth limits of oceanic basement microbiological activity have yet to be explored, but microbial processes occurring in the submarine deep biosphere may hold the key to the development and survival of life on the Earth and other planets.

Despite the central role that the ocean crust plays in the evolution of our planet, our sampling of in situ oceanic basement is poor, and consequently, our un- derstanding of the fundamental processes involved in the formation and evolution of the oceanic crust remains rudimentary. Samples of basalts, dikes, gabbros, and peridotites have been retrieved by dredging and shallow drill holes from most of the ocean basins, but the geological context of these samples is rarely well established. As such, the nature and variability of the composition and structure of the ocean crust away from transform faults and other tectonic windows remain poorly known. Drilling a complete crustal section has always been a major goal of scientific ocean drilling (Bascom, 1961; Shor, 1985), but achievement of this goal has been impeded by technical difficulties and the time investments required. The distribution of drill holes in intact oceanic crust of different ages and formed at different spreading rates is extremely sparse (Fig. F1) (see Wilson, Teagle, Acton, et al., 2003, for full documentation of basement drilling). Before Integrated Ocean Drilling Program (IODP) Expedition 309, Hole 504B, drilled during the Deep Sea Drilling Project (DSDP) and Ocean Drilling Program (ODP) on the southern flank of the Costa Rica Rift, was the only hole to penetrate a complete sequence of extrusive lavas and partially through the underlying sheeted dike complex (Alt, Kinoshita, Stokking, et al., 1993). The dike/gabbro boundary has never been drilled, and the nature of the plutonic rocks directly subjacent to the sheeted dike complex is not known, despite this zone being perhaps the most influential in determining the mechanisms of crustal accretion and the geometry of magmatic and hydrothermal interactions. Our poor sampling of ocean crust at different spreading rates and crustal ages and the absence of information on crustal variability compromise our ability to extrapolate observations from specific sites to global descriptions of magmatic accretion processes and hydrothermal exchange in the ocean crust.

Oceanic crust formation and evolution are primary themes for investigation in the Initial Science Plan for the Integrated Ocean Drilling Program (International Working Group, 2001) and other major science priority submissions (e.g., Conference on Multiple Platform Exploration of the Ocean [COMPLEX], Pisias and Delaney, 1999; Ocean Drilling Program Geochemistry Futures Workshop, Murray et al., 2002). These documents and others specifically related to the study of the oceanic lithosphere (Second Conference on Scientific Ocean Drilling [COSOD II]; ODP Long Range Plan, Ocean Drilling Program, 1996; ODP-International Cooperation in Ridge-Crest Studies-International Association of Volcanology and Chemistry of the Earth's Interior workshop; 4DArchitecture of the Ocean Crust Program Planning Group) reemphasize deep drilling to obtain complete 
sections of the ocean crust as a priority and note that the deep drilling capabilities of riserless technology have yet to be fully utilized.

Offset drilling strategies, where deeper portions of the ocean crust are sampled by drilling in tectonic windows, have recently been high priorities for ocean drilling (COSOD II, 1987; Ocean Drilling Program, 1996). Drilling at several sites has provided a wealth of new data and understanding of gabbros and peridotites from the lower crust and serpentinized upper mantle (e.g., Hess Deep: Gillis, Mével, Allan, et al., 1993; Kane Fracture Zone area: Cannat, Karson, Miller, et al., 1995; Southwest Indian Ridge: Dick, Natland, Miller, et al., 1999; $14^{\circ}-16^{\circ} \mathrm{N}$ MidAtlantic Ridge: Kelemen, Kikawa, Miller, et al., 2004; Atlantis Massif: Expedition 304 Scientists, 2005, Expedition 305 Scientists, 2005). However, serious problems still exist with drilling tectonized rocks with little sediment blanket or without erosional removal of fractured material, and it is also commonly difficult to relate drilled sections to regional geology (e.g., Gillis, Mével, Allan, et al., 1993). Perhaps the most successful deep drilling of the oceanic basement has occurred in crust formed at slow to ultraslow spreading rates on plutonic massifs exposed near ridge-transform fault intersections (Holes 735B and U1309D). These holes boast deep penetration at high rates of recovery (Dick, Natland, Miller, et al., 1999; Expedition 304 Scientists, 2005; Expedition 305 Scientists, 2005) but are probably not representative of the majority of ocean crust that formed at faster spreading rates and in the middle of ridge segments.

Composite sections are not substitutes for deep in situ penetrations, and drilling deep holes to obtain complete upper crustal sections continues to be a primary challenge for scientific ocean drilling (Dick and Mével, 1996; Murray et al., 2002). Unfortunately, there are no on-land alternatives to drilling in the oceans. Although ophiolites, ancient slices of ocean crust now preserved on land, provided much of the early inspiration for ocean crust studies, the classic outcrops of Semail ophiolite (Oman) and Troodos massif (Cyprus) formed in suprasubduction zone settings reference (e.g., Pearce and Cann, 1971; Pearce et al., 1981; Rautenschlein et al., 1985) and their different magma and volatile chemistries compromise their applicability for understanding processes in the major ocean basins. Macquarie Island (Varne et al., 2000), uplifted along the Australian/ Pacific plate boundary $\sim 1000 \mathrm{~km}$ south of New Zealand, may be the only outcrop of subaerially exposed ocean crust formed at a mid-ocean ridge, but the island is complexly faulted and is an environmentally sensitive United Nations Educational, Sci- entific, and Cultural Organization World Heritage site from which drilling, even for scientific purposes, is prohibited.

IODP Expedition 309/312 builds on the success of ODP Leg 206, during which Hole 1256D was established, to drill a complete section of the upper oceanic crust. Hole 1256D in the Guatemala Basin is hosted by 15 m.y. old crust that formed at the equatorial East Pacific Rise (EPR) during a sustained period of superfast seafloor spreading (Fig. F2) (Wilson, Teagle, Acton, et al., 2003). It is the first basement borehole prepared with the infrastructure desirable for drilling a moderately deep hole into the oceanic crust $(\sim 1.5-2 \mathrm{~km})$. Following preliminary coring to document the sedimentary overburden at Site 1256, a reentry cone supported by 20 inch casing and large-diameter (16 inch) casing all the way through the sediment cover and cemented $19 \mathrm{~m}$ into basement was installed in Hole 1256D during Leg 206. The cone and casing facilitates multiple reentries and helps to maintain hole stability essential for deepening Hole 1256D down through the dikes and into the gabbros. The large-diameter casing leaves open the possibility that one or two more casing strings could be installed in Hole 1256D should future expeditions need to isolate unstable portions of the hole. During Leg 206, the upper $502 \mathrm{~m}$ of the igneous crust was cored with moderate to high recovery (average $=\sim 48 \%$ ), and the uppermost crust at this site comprises a sequence of massive flows and thinner sheet flows with subordinate pillow basalt and breccias. The sequence has normal mid-oceanridge basalt (N-MORB) composition similar to modern EPR basalts and is slightly to moderately altered. It was extruded over sufficient time to record stable geomagnetic field directions and capture transitional directions in the upper units as the geomagnetic field reversed. Importantly, operations during Leg 206 in Hole 1256D concluded with the hole clean of debris and in excellent condition.

The goal of the IODP Superfast Spreading Rate Crust mission (Expedition 309/312) was to core through the remaining extrusive rocks and the underlying sheeted dike complex and into the upper gabbros. This continuous section of in situ oceanic crust generated at a superfast spreading rate in the eastern $\mathrm{Pa}$ cific will

- Provide the first sampling of a complete section of ocean crust from the extrusive rocks and dikes and into the gabbros. This will confirm whether ocean crust formed at a superfast spreading rate conforms to a "Penrose" ophiolite stratigraphy.

- Confirm the nature of high-level axial magma chambers. 
- Define the relationship between magma chambers and their overlying lavas and the interactions between magmatic, hydrothermal, and tectonic processes.

- Provide in situ calibration of seismic velocity and magnetic measurements made from surface ships so that these regional-scale geophysical measurements can be related to geology.

\section{Rationale for site selection and location criteria for deep drilling}

The key to proposing the Superfast Spreading Rate Crust campaign (Leg 206 and Expedition 309/312) was to identify a style of crustal accretion where the extrusive lavas and dikes overlying the gabbros were predicted to be relatively thin, thus increasing the likelihood of penetrating through the complete upper crustal section in the fewest drilling days. The recognition that crust formed at a superfast spreading rate is a compelling target for deep drilling follows the observation that there is an inverse relationship between the depth of axial low-velocity zones imaged by seismic experiments, interpreted to be melt lenses, and spreading rate (Purdy et al., 1992) (Fig. F3). Even allowing for an additional thickness of lavas that flowed from the ridge axis to cover the immediate flanks, the uppermost gabbros should be at relatively shallow depths in superfastspreading crust. The predicted depth to gabbros at Site 504 on the south flank of the intermediatespreading Costa Rica Rift is $>2.5 \mathrm{~km}$, whereas the depth to the axial low-velocity zones at typical fast spreading rate $(\sim 80-150 \mathrm{~mm} / \mathrm{y})$ crust on the EPR is $\sim 1-2 \mathrm{~km}$. The estimated depth to an axial melt lens for ocean crust formed at a superfast spreading rate is 700-1000 m, and the anticipated depth to the gabbros for Site 1256 is $\sim 1000-1300 \mathrm{~m}$, allowing for a reasonable thickness $(\sim 300 \mathrm{~m})$ of near-axial lava flows.

Although perhaps only $20 \%$ of the global ridge axis is separating at fast spreading rates $(>80 \mathrm{~mm} / \mathrm{y}$ full rate), $\sim 50 \%$ of the present-day ocean crust and $\sim 30 \%$ of the Earth's total surface was produced by this pace of ocean spreading. At least in terms of seismic structure (Raitt, 1963; Menard, 1964), crust formed at fast spreading rates is relatively simple and uniform. Deep drilling at Site 1256 will characterize one endmember style of mid-ocean-ridge accretion, and the successful deep sampling of such crust in a single location can reasonably be extrapolated to describe a significant portion of the Earth's surface.

\section{Site selection}

A recent reconsideration of magnetic anomalies at the southern end of the Pacific/Cocos plate bound- ary has identified crust formed at a full spreading rate of $220 \mathrm{~mm} / \mathrm{y}$ from 20 to $11 \mathrm{Ma}$ (Wilson, 1996) (Fig. F2). This is significantly faster than the present fastest spreading rate $(\sim 145 \mathrm{~mm} / \mathrm{y})$ for crust forming at $\sim 30^{\circ} \mathrm{S}$ on the EPR. From this region created by superfast spreading, a single drill site in the Guatemala Basin, initially designated GUATB-03C and now known as Site 1256, was selected on young, 15 m.y. old ocean crust. The details of site survey operations and the reasons for the selection of this particular site are outlined in detail in Wilson, Teagle, Acton, et al. (2003).

In addition to the shallow depth to gabbros predicted from formation at a superfast spreading rate, Site 1256 has a number of specific attributes that indicate that this site provides an excellent opportunity to sample a complete section of upper oceanic crust. Site 1256 formed at an equatorial latitude (Fig. F4), and high equatorial productivity resulted in robust sedimentation rates ( $>30 \mathrm{~m} / \mathrm{m} . \mathrm{y}$.) and the rapid burial of the young basement. The thick sediment blanket enabled installation of a reentry cone with 20 inch casing that forms the foundation for deployment of the second 16 inch diameter casing string that was cemented $19 \mathrm{~m}$ into the uppermost basement. At $15 \mathrm{Ma}$, Site 1256 is significantly older than the crust at Hole 504B (6.9 Ma), and lower temperatures are anticipated at midlevels of the crust. As such, high basement temperatures, which can preclude drilling operations, should not be reached until gabbroic rocks have been penetrated. Logistically, Site 1256 has a number of advantages. It is $\sim 3.5$ days steaming from the Panama Canal, and the short transit time allows for maximum time on site during drilling expeditions. As transfer between the Pacific and Atlantic Oceans is common because of the scheduling demands of scientific drilling, close proximity to the Panama Canal has allowed the timely rescheduling of return visits to the site.

\section{Geological setting of Hole 1256D}

Site $1256\left(6^{\circ} 44.1^{\prime} \mathrm{N}, 91^{\circ} 56.1^{\prime} \mathrm{W}\right)$ lies in $3635 \mathrm{~m}$ of water in the Guatemala Basin on Cocos plate crust formed 15 m.y. ago on the eastern flank of the EPR (Figs. F2, F4). The depth of the site is close to that predicted from bathymetry models of plate cooling (e.g., Parsons and Sclater, 1977). The site sits astride the magnetic Anomaly $5 \mathrm{Bn}-5 \mathrm{Br}$ magnetic polarity transition (Fig. F5A). This crust accreted at a superfast spreading rate $(220 \mathrm{~mm} / \mathrm{y}$ full rate; Wilson, 1996) and lies $\sim 1150 \mathrm{~km}$ east of the present crest of the EPR and $\sim 530 \mathrm{~km}$ north of Cocos Ridge. The site formed on a ridge segment at least $400 \mathrm{~km}$ in length, $\sim 100 \mathrm{~km}$ north of the ridge-ridge-ridge triple junction between the Cocos, Pacific, and Nazca plates 
(Fig. F4). This location was initially at an equatorial latitude within the equatorial high-productivity zone and endured high sedimentation rates $(>30 \mathrm{~m} /$ m.y.; e.g., Farrell et al., 1995; Wilson, Teagle, Acton, et al., 2003). Sediment thickness in the region is between 200 and $300 \mathrm{~m}$ and is $250 \mathrm{~m}$ at Site 1256 (Wilson, Teagle, Acton, et al., 2003).

Site 1256 has a seismic structure reminiscent of typical Pacific off-axis seafloor (Fig. F6). Upper Layer 2 velocities are $4.5-5 \mathrm{~km} / \mathrm{s}$ and the Layer $2-3$ transition is between 1200 and 1500 meters subbasement (msb) (Fig. F7). Total crustal thickness at Site 1256 is estimated at $\sim 5-5.5 \mathrm{~km}$. Further to the northeast of Site $1256(15-20 \mathrm{~km})$, a trail of $\sim 500 \mathrm{~m}$ high circular seamounts rise a few hundred meters above the sediment blanket (Fig. F5B).

Using the site survey multichannel seismic (MCS) data (Wilson et al., 2003), we have constructed a geological sketch map of the uppermost basement in the GUATB-03 survey region (Fig. F8). The bathymetry in the GUATB-03 survey area is generally subdued, and Site 1256 sits atop a region of smooth basement topography ( $<10 \mathrm{~m}$ relief). However, elsewhere in the region the top of basement shows a number of offsets along northwest-striking normal faults, and an abyssal hill relief of up to $100 \mathrm{~m}$ is apparent in the southwest part of the area. Relief to the northeast is lower and less organized. In the northeast sector of the GUAT-3B region, there is evidence for a basement thrust fault with a strike approximately orthogonal to the regional fabric (Wilson et al., 2003; Hallenborg et al., 2003). This feature dips gently to the northwest $\left(\sim 15^{\circ}\right)$ and is clearly discernible to a depth of $\sim 1.3 \mathrm{~km}$ on seismic Line EW9903-28 (Wilson et al., 2003), but the feature is less pronounced on seismic Line EW9903-27, indicating that the offset on the thrust decreases to the southwest.

Additional processing (A. Harding, unpubl. data) of ocean bottom seismometer recordings indicates that there is discernible variation in the average seismic velocity $(\sim 4.54-4.88 \mathrm{~km} / \mathrm{s})$ of the uppermost $(\sim 100$ $\mathrm{m})$ basement and that there is regional coherence in the velocity variations (Fig. F8A). Two principal features are apparent: a $5-10 \mathrm{~km}$ wide zone of relatively high upper basement velocities $(>4.82 \mathrm{~km} / \mathrm{s})$ that can be traced $\sim 20 \mathrm{~km}$ to the edge of data coverage southeast of Site 1256 and a relatively low velocity (4.66$4.54 \mathrm{~km} / \mathrm{s}$ ) bull's-eye centered around the crossing point of seismic Lines EW9903-21 and 25.

The uppermost basement at Site 1256 is capped by a massive lava flow $>74 \mathrm{~m}$ thick. This flow is relatively unfractured, with shipboard physical properties measurements on discrete samples indicating $V_{\mathrm{p}}>5.5$ $\mathrm{km} / \mathrm{s}$ (Wilson, Teagle, Acton, et al., 2003). As such, it is likely that the area of relatively high uppermost basement seismic velocities delineates the extent of the massive flow penetrated in Holes $1256 \mathrm{C}$ and 1256D. Assuming an average thickness of $40 \mathrm{~m}$, this would conservatively suggest an eruption volume $>3$ $\mathrm{km}^{3}$, plausibly $>10 \mathrm{~km}^{3}$. This is extremely large when compared to the size of mid-ocean-ridge axial lowvelocity zones that are thought to be high-level melt lenses and which typically have volumes $\sim 0.05-0.15$ $\mathrm{km}^{3} / \mathrm{km}$ of ridge axis and generally appear to be only partially molten (Singh et al., 1998).

Sheet flows ( $<3 \mathrm{~m}$ thick) and massive flows $(>3 \mathrm{~m})$ make up most of the lava stratigraphy cored at Site 1256, and such lava morphologies dominate crust formed at fast spreading rates, away from segment tips (e.g., White et al., 2000, 2002). Subordinate pillow lavas are present in Hole 1256D, and because of the large number of fractures and pillow interstices, seismic velocities are generally lower than more massive lava flows. We speculate that the bull's eye of relatively low seismic velocities is a thick pile of dominantly pillowed lava flows.

\section{Scientific objectives of Expedition 309/312}

During Expedition 309/312, drilling of a continuous section through volcanic basement and the underlying sheeted dike complex down into the uppermost plutonic rocks in Hole 1256D continued. The cores recovered from and the wireline measurements made in Hole $1256 \mathrm{D}$ will provide unique information to address the following specific scientific objectives (Table T1):

\section{Test the prediction, from the correlation of spreading rate with decreasing depth to the axial low-velocity zones (e.g., Purdy et al., 1992), that gabbros representing the crystallized melt lens will be encountered at 1000-1300 msb at Site 1256.}

The transition from sheeted dikes to gabbros has never been drilled, and this remains an important objective in achieving a complete or even composite oceanic crustal section. The dike-gabbro transition and the uppermost plutonic rocks are assumed to be the frozen axial melt lens and the fossil thermal boundary layer between magma chambers and vigorous hydrothermal circulation. Detailed knowledge of the dike-gabbro transition zone is critical to discerning the mechanisms of crustal accretion. The textures and chemistries of the uppermost gabbros are presently unknown but are central to understanding crustal construction. At present, we lack samples that link gabbroic rocks to the overlying lavas, leading to the following questions:

- What is the geological nature of the low-velocity zones imaged by MCS reflection studies at the axes of mid-ocean ridges? 
- Is the melt lens imaged at mid-ocean ridges made of cumulate rocks from which magmas are expelled to form the dikes and lavas, which then subside to form the lower crust? Or are the uppermost gabbros coarse-grained chemical equivalents of the dikes and extrusive rocks frozen at the base of the sheeted dikes?

- Does most of the crustal accretion occur at deeper levels through the intrusion of multiple thin sills?

- What are the cooling rates of magma chambers?

These questions can be answered through petrological and geochemical studies of gabbros (e.g., Natland and Dick, 1996; Kelemen et al., 1997; Manning et al., 2000; MacLeod and Yaoancq, 2000; Coogan et al., 2002a, 2002b) and the overlying lavas and their mineral constituents.

\section{Determine the lithology and structure of the upper oceanic crust from a superfast spreading rate end- member.}

Some basic observations regarding the architecture of ocean crust, including the lithology, geochemistry, and thicknesses of the volcanic and sheeted dike sections and how these vary with spreading rate or tectonic setting, are not well known. Karson (2002) provides estimates of the thicknesses of lavas and sheeted dikes from crust generated at fast and intermediate spreading rates (600-900 m lavas and 300$1000 \mathrm{~m}$ dikes at Hess Deep; 500-1300 m lavas and 500 to $>1000 \mathrm{~m}$ dikes in Hole 504B and at the Blanco Fracture Zone). With the exception of the incomplete section in Hole 504B, these estimates are based on observations of highly disrupted exposures, where structural complexities and the uniqueness of the geological environments indicate that such estimates should be treated with caution. The results of Expedition 309/312 will determine the thicknesses of these upper crustal units at Site 1256 and document the styles of deformation and magmatic accretion. Studies of tectonic exposures of oceanic crust suggest that intense brittle deformation, faulting and distributed zones of fracturing, and large amounts of dike rotation are common within sheeted dike complexes in crust formed at fast and intermediate spreading rates (Karson, 2002; Karson et al., 2002; Stewart et al., 2005). It is difficult, however, to separate primary mid-ocean-ridge geometries from deformation related to the unroofing of these tectonic windows. In contrast, large blocks of the sheeted dike complex in the Semail ophiolite in Oman exhibit little of such faulting or distributed fracturing (Umino et al., 2003). Seismic profiles of the Site 1256 region show well-developed subhorizontal reflectors to $~ 800-900 \mathrm{msb}$ (Fig. F6), providing little evidence for rotation of the upper crust in this region.
Drilling the sheeted dike complex at Site 1256 will enable evaluation of whether such faulting and fracturing observed in tectonic exposures are representative of oceanic crust or merely related to their complex tectonic settings. Most dikes in sheeted dike complexes in tectonic exposures of crust generated at intermediate and fast spreading rates and in Hole 504B in intermediate rate crust generally dip away from the spreading axis, suggesting tectonic rotation of crustal blocks (Karson, 2002). Do such rotations also occur in crust generated at superfast spreading rates, and are they similar, or is the crust less tectonically disrupted? A single drill hole may not conclusively answer this question but should provide important constraints.

\section{Correlate and calibrate seismic and magnetic imaging of the crustal structure with basic geological observations.}

Ground-truthing regional geophysical techniques such as seismic and magnetic imaging is a key goal of the IODP Initial Science Plan and related documents (e.g., COMPLEX). A fundamental question we will address in this experiment is how velocity changes within seismic Layer 2 and whether the Layer 2-Layer 3 transition relates to physical, lithological, structural, and/or alteration variations in the volcanic rocks, dikes, and gabbros. At Site 504, in crust generated at an intermediate spreading rate ridge, the Layer 2-Layer 3 transition lies within the 1 $\mathrm{km}$ thick sheeted dike complex and coincides with a metamorphic change (Detrick et al., 1994; Alt et al., 1996), but it is unknown whether the results from Hole 504B are representative of ocean crust in general or of crust generated at different spreading rates. Is the depth to gabbros shallower in crust generated at a superfast spreading rate, as predicted, and what are the relative thicknesses of volcanic and dike sections compared with crust constructed at slow or intermediate spreading rates?

Marine magnetic anomalies are one of the key observations that led to the development of plate tectonic theory, through recognition that the ocean crust records the changing polarity of the Earth's magnetic field through time (Vine and Matthews, 1963). It is generally assumed that micrometer-sized grains of titanomagnetite within the erupted basalts are the principal recorders of marine magnetic anomalies. However, recent studies of tectonically exhumed lower crustal rocks and serpentinized upper mantle indicate that these deeper rocks may also be a significant source of the magnetic stripes (Hosford et al., 2003). Coring a complete section through the sheeted dike complex will allow evaluation of the contribution of these rocks to marine magnetic 
anomalies. Whether these deeper rocks have a significant influence on the magnetic field in undisrupted crust is unknown, as is the extent of secondary magnetite growth in gabbros and mantle assemblages away from transform faults. Sampling the plutonic layers of the crust will test the Vine-Matthews hypothesis by characterizing the magnetic properties of gabbros through drilling normal ocean crust on a well-defined magnetic stripe, away from transform faults.

\section{Investigate the interactions between magmatic and alteration processes, including the relationships between extrusive volcanic rocks, sheeted dikes, and underlying gabbroic rocks.}

Little information presently exists on the heterogeneity of hydrothermal alteration in the upper crust or the variability of associated thermal, fluid, and chemical fluxes. How these phenomena vary at similar and different spreading rates is unknown. Metamorphic assemblages and analyses of secondary minerals in material recovered by deep drilling can provide limits on the amount of heat removed by hydrothermal systems and place important constraints on the geometry of magmatic accretion and the thermal history of both the upper and lower crust (e.g., Manning et al., 2000; MacLeod and Yaoancq, 2000; Coogan et al., 2002a, 2002b). Fluid flow paths, the extent of alteration, and the nature of deep subsurface reaction and shallower mixing zones are all critical components of our understanding of hydrothermal processes that can only be tackled by drilling. These problems can be addressed by examining the "stratigraphy" and relative chronology of alteration within the extrusive lavas and dikes, by determining whether disseminated sulfide mineralization resulting from fluid mixing and a large step in thermal conditions is present at the volcanic-dike transition (as in Hole 504B and many ophiolites), and by evaluating the grade and intensity of alteration in the lower dikes and upper gabbros. The lowermost dikes and upper gabbros have been identified as the conductive boundary layer between the magma chambers and the axial high-temperature hydrothermal systems, as well as the subsurface reaction zone where downwelling fluids acquire black-smoker chemistry (Alt, 1995; Alt et al., 1996; Vanko and Laverne, 1998; Gillis et al., 2001). However, extensive regions of this style of alteration or zones of focused discharge are poorly known, and information from ophiolites may not be applicable to in situ ocean crust (Richardson et al., 1987; Schiffman and Smith, 1988; Bickle and Teagle, 1992; Gillis and Roberts, 1999). Drilling beyond the boundary between the lower dikes and upper gabbros will help trace recharge fluid compositions, estimate hydrothermal fluid fluxes (e.g., Teagle et al., 1998, 2003; Laverne et al., 2001; Gillis et al., 2005), and integrate the thermal requirements of hydrothermal alteration in sheeted dikes and underlying gabbros with the magmatic processes in the melt lens. Detailed logging of cores combined with geochemical analyses will enable determination of geochemical budgets for hydrothermal alteration (e.g., Alt et al., 1996; Alt and Teagle, 1999, 2000; Bach et al., 2003). Is there a balance between the effects of low-temperature alteration of lavas versus high-temperature hydrothermal alteration of dikes and gabbros? This is a critical check on global budgets for many elements $(\mathrm{Mg}, \mathrm{K}$, ${ }^{87} \mathrm{Sr}, \mathrm{U}$, and ${ }^{18} \mathrm{O}$ ) presently estimated from vent fluid chemistries, riverine inputs, and thermal models (e.g., review of Elderfield and Schultz, 1996).

The discovery of microorganisms that colonize and extract energy from volcanic glass in the upper oceanic crust has added new dimensions to seafloor alteration studies. Microbial alteration of volcanic glass has been shown to decrease with basement depth at other sites (Furnes and Staudigel, 1999). The temperature and depth limits to subbasement microbiological activity remain unknown but can be investigated by deep sampling and study of microbial alteration textures, chemical and isotopic indicators, and molecular microbiology (e.g., Blake et al., 2001; Alt et al., 2003; Banerjee and Muehlenbachs, 2003).

\section{Principal results of ODP Leg 206}

The major objectives of Leg 206 were to establish a cased reentry hole that is open for future drilling and to achieve a target penetration in excess of $500 \mathrm{msb}$. Before basement drilling was initiated, a series of holes was drilled to thoroughly characterize the sediments and magneto- and biostratigraphy of the sedimentary overburden and to determine the casing depth into basement for the main hole. Four holes were drilled during Leg 206, with Holes 1256A, $1256 \mathrm{~B}$, and $1256 \mathrm{C}$ recovering a near-complete record of the $250 \mathrm{~m}$ thick sedimentary overburden. Pilot Hole 1256C penetrated $88.5 \mathrm{~m}$ into basement, with Hole $1256 \mathrm{D}$ being the cased reentry hole with a large reentry cone supported by $95 \mathrm{~m}$ of 20 inch casing and $269.5 \mathrm{~m}$ of 16 inch casing cemented into the uppermost basement. The total depth of penetration of Hole 1256D during Leg 206 was 752 mbsf, including $502 \mathrm{~m}$ drilled into basement. Recovery of igneous rocks was good, and excellent in places, with average recovery rates of $61.3 \%$ and $47.8 \%$ in Holes $1256 \mathrm{C}$ and $1256 \mathrm{D}$, respectively (Wilson, Teagle, Acton, et al., 2003).

The sedimentary overburden is divided into two units: Unit I (0-40.6 mbsf) is clay rich, with a few 
carbonate-rich layers; Unit II (40.6-250.7 mbsf) is predominantly biogenic carbonate. The interval from 111 to 115 mbsf is rich in biogenic silica, which forms a distinct diatom mat, deposited at $\sim 10.8 \mathrm{Ma}$. Chert nodules are a common feature below 111 mbsf, and red-brown iron oxide-rich silicified sediments that may be recrystallized metalliferous sediments are present directly over the basement (within $\sim 1 \mathrm{~m}$ ). The primary control on the interstitial water chemistry at Site 1256 is diffusion between seawater and basement fluids, with a continuous chert bed at 158 mbsf providing a low-diffusivity barrier. Calcareous microfossil biostratigraphy is in good agreement with magnetostratigraphy. Calculated sedimentation rates vary from $\sim 6$ to $36 \mathrm{~m} / \mathrm{m}$.y. and decrease with time as the site moved away from the high-productivity zone near the paleoequator and the cooling lithospheric plate subsided (Wilson, Teagle, Acton, et al., 2003).

Approximately $60 \%$ of the igneous basement in Holes $1256 \mathrm{C}$ and $1256 \mathrm{D}$ consists of thin (tens of centimeters to $<3 \mathrm{~m}$ ) basaltic sheet flows separated by chilled margins (Fig. F9). Massive flows ( $>3 \mathrm{~m}$ thick) are the second most common rock type, including the thick ponded flow near the top of the holes. Minor intervals of pillow lavas $(20 \mathrm{~m})$ and hyaloclastite (a few meters) and a single dike were recovered in Hole 1256D. The low proportion of pillow lavas $(<10 \%)$ indicates rapid lava emplacement on low topographic relief, consistent with thermal model predictions of $<1 \mathrm{~km}$ vertical thickness of the dike zone.

The uppermost lavas, sampled only in Hole 1256C because of setting casing in Hole 1256D, are composed of thin basaltic sheet flows a few tens of centimeters to $\sim 3 \mathrm{~m}$ thick, separated by chilled margins and containing rare intervals of recrystallized sediment. Basement Units 1256C-18 and 1256D-1 each consist of a single cooling unit of cryptocrystalline to fine-grained basalt, interpreted to be a ponded lava flow and serving as a clear marker unit for correlation of the igneous stratigraphy between holes. A total of $32 \mathrm{~m}$ of this unit was cored in Hole 1256C, of which $29 \mathrm{~m}$ was recovered. This ponded flow is much thicker $30 \mathrm{~m}$ away in Hole $1256 \mathrm{D}$, where it has a minimum thickness of $74.2 \mathrm{~m}$, indicating steep paleotopography. The groundmass of the interior of the flow is fine grained but is deformed and thermally metamorphosed $\sim 1.5 \mathrm{~m}$ from its base.

The transition from axial eruptions to lavas that flowed out onto the ridge flanks was not determined during Leg 206. However, it was recognized that the thickness of the massive ponded flow requires significant basement relief in order to pool the lava, and this would only be developed significantly off axis $(5-10 \mathrm{~km})$.
The remainder of the section in Hole $1256 \mathrm{D}$ (with the exception of Units 1256D-3, 4a, 4c, 8c, 16d, and 21) consists of sheet flows tens of centimeters to $\sim 3$ $\mathrm{m}$ thick with uncommon massive flows 3.5-16 m thick. These sheet and massive flows are aphyric to sparsely phyric, cryptocrystalline to microcrystalline basalt and are distinguished by common chilled margins with fresh or altered glass.

One $20 \mathrm{~m}$ thick interval of aphyric to sparsely phyric cryptocrystalline pillow basalt with glassy chilled margins was recovered from near the top of the section (Unit 1256D-3), as well as two 1.0-1.7 m thick hyaloclastite intervals (Units 1256D-4c and 21). Also recovered was a $0.3 \mathrm{~m}$ thick interval of volcanic breccia composed of angular fragments of cryptocrystalline basalt embedded in a matrix of altered glass (Unit 1256D-4a).

The basalts show large variations in grain size and textures from holohyaline in the outermost chilled margins of lava flows to the coarser intergranular textures in the lava pond. The basaltic lavas are dominantly aphyric to sparsely phyric, but where phenocrysts are present, olivine is the dominant phase with subordinate plagioclase, minor clinopyroxene, and rare spinel. Measurements of petrographically fresh samples revealed general downhole variations with $\mathrm{Mg \#}(=\mathrm{Mg} /[\mathrm{Mg}+\mathrm{Fe}]), \mathrm{Cr}, \mathrm{Ni}$, and $\mathrm{Ca} / \mathrm{Al}$ ratios broadly increasing with depth, whereas $\mathrm{TiO}_{2}, \mathrm{Fe}_{2} \mathrm{O}_{3}$, $\mathrm{Zr}, \mathrm{Y}, \mathrm{Nb}, \mathrm{V}$, and Sr broadly decrease with depth, although smaller-scale variations are superimposed on these trends (Fig. F9). All Leg 206 lavas from Site 1256 plot in the N-MORB field on a Zr-Y-Nb ternary diagram.

In the lavas directly below the large massive flow, there is a sharp increase in Mg\# accompanied by an increase in incompatible element concentrations (Fig. F9). The combination of high Mg\# and high incompatible element concentrations argues against differentiation as the cause of the enrichments and suggests that there is variation in the primitive magma composition.

Rocks throughout Holes 1256C and 1256D exhibit a dark gray background alteration, where the rocks are slightly to moderately altered and olivine is replaced and pore spaces are filled by saponite and minor pyrite as the result of low-temperature seawater interaction at low cumulative seawater/rock ratios. Veinrelated alteration manifests as different-colored alteration halos along veins. Black halos contain celadonite and result from the reaction of young ocean crust $(<1-2 \mathrm{Ma})$ with distal upwelling low-temperature hydrothermal fluids enriched in iron, silica, and alkalis (Edmond et al., 1979; see summary in Alt, 1999). Iron oxyhydroxide-rich brown mixed halos are later features, which formed by circulation of ox- 
idizing seawater. Brown halos have a similar origin and formed along fractures that were not bordered by previously formed black halos. This vein-related alteration occurs irregularly throughout Hole 1256D below the massive Unit 1256D-1 but is concentrated in two zones of greater permeability and, consequently, increased fluid flow, at 350-450 and 635750 mbsf. The appearance of albite and saponite partially replacing plagioclase below 625 mbsf indicates a change in alteration conditions. This change may result in part because of slightly higher temperatures at depth as the lava/dike boundary is approached or from interaction with more evolved fluid compositions (e.g., decreased $\mathrm{K} / \mathrm{Na}$ and elevated silica).

When compared with other basement sites, Hole 1256D (Fig. F10) contains far fewer brown, mixed, and black alteration halos. The abundance of carbonate veins in Hole 1256D is also lower than at many other sites. Site 1256 is, however, quite similar to Site 801, also in crust generated at a fast-spreading ridge, albeit $170 \mathrm{~m} . \mathrm{y}$. ago. One important feature is the lack of any oxidation gradient with depth in Hole 1256D, in contrast to the stepwise disappearance of iron oxyhydroxide and celadonite in Hole 504B and the general downward decrease in seawater effects at Sites 417 and 418. In contrast, alteration appears to have been concentrated into different zones that may be related to the architecture of the basement, such as lava morphology, distribution of breccia and fracturing, and the influence of these on porosity and permeability. Clearly, there is greater variation in the processes of alteration occurring in the oceanic crust than is recorded at Sites 504, 417, and 418 , which have served as "reference" sections to date. This illustrates the point that models for the formation and alteration of oceanic basement based on crust formed at slow and intermediate spreading rates cannot automatically be applied to crust generated at fast spreading rates.

Structures in the basement at Site 1256 include both igneous features and postmagmatic deformation. Igneous structures such as flow layering, preferred phenocryst orientation, or fine layering delineated by coalesced spherulites or vesicles are observed near the chilled margins of sheet flows but are best developed near the upper and basal margin of the massive ponded flow (Units 1256C-18 and 1256D-1). The massive ponded flow exhibits other features not observed in the rest of the hole, such as the folding of flow layering and shear-related structures, highlighting the complex internal dynamics occurring during the emplacement and cooling of this large igneous body. Folds at the top of the ponded lava have gently dipping axial planes, whereas such features become steeper toward the bottom. Shear indicators, such as pull-aparts and tension gashes, now filled with latestage magma, are more common toward the base of the ponded lava.

Brittle deformation is common throughout the upper crust sampled by Holes $1256 \mathrm{C}$ and $1256 \mathrm{D}$ and includes veins with various morphologies, shear veins, joints, and breccias. There is no systematic variation in the structural attitude (true dip) with depth, and this probably reflects the influence of other factors, such as grain size or lava morphology, rather than regional tectonics or the local stress field. Aphyric basalt in sheet flows exhibits a more irregular fracture pattern than coarser grained lavas. Shear veins indicate both normal and reverse senses of shear, suggesting the occurrence of some, although probably local, compressional components. Shear veins are most common in the massive ponded lava (Units 1256C-18 and 1256D-1) and in sheet flows from Cores 206-1256D-27R through 43R, where the geometries of the infilling fibers indicate reverse senses of shear. Brecciated rocks of different styles occur throughout the cores but are most common in the sheet flows. Textural features indicate that most breccias formed either by reworking of lava tops (both chilled and cryptocrystalline basalt) or by the fracturing of rock assisted by relatively high fluid pressures.

Basalt samples from Site 1256 show a strong tendency to have been partially or fully remagnetized during drilling, much more so than for most other DSDP and ODP sites. However, in many cases, a preoverprint component can be discerned, if not always measured accurately, with the shipboard equipment. For Hole 1256D, most samples from igneous Units $1256 \mathrm{D}-3$ through $8 \mathrm{a}$ and 14 through 26 demagnetize to a shallow inclination, as expected for the equatorial paleolatitude. For Hole $1256 \mathrm{C}$, all samples have steep inclinations and most are dominated by overprint, but a few samples from Units 1256C-3, 7, 18c, $18 \mathrm{~h}$, and 22 show evidence for a stable, steep component distinct from the overprint. The steep inclination may reflect eruption during the magnetic polarity transition between Chrons $5 \mathrm{Br}$ and $5 \mathrm{Bn}$, which would imply transport of these uppermost lavas $>5$ $\mathrm{km}$ from the ridge axis.

The basement rocks cored during Leg 206 at Site 1256 show little variation in physical properties with depth. The rocks in and above the massive ponded flow (Units 1256C-1 through 18 and 1256D-1; 276$350 \mathrm{mbsf}$ ) have an average bulk density of $2.89 \pm$ $0.03 \mathrm{~g} / \mathrm{cm}^{3}$, which is not significantly different from the basalts below when considered together $(2.8 \pm$ $\left.0.1 \mathrm{~g} / \mathrm{cm}^{3}\right)$. However, there is a significant decrease in average density $\left(2.7 \pm 0.1 \mathrm{~g} / \mathrm{cm}^{3}\right)$ for the lava flows immediately below Unit $1256 \mathrm{D}-1$ from 350 to 451 
mbsf (Units 1256D-2 through 8a). The average porosity of the basement rocks drilled during Leg 206 is $5 \% \pm 3 \%$ within a total range of $2 \%-19 \%$. The average thermal conductivity of basalts from Hole 1256D is $1.8 \pm 0.1 \mathrm{~W} /(\mathrm{m} \cdot \mathrm{K}) . V_{\mathrm{p}}$ of discrete basalt samples from Leg 206 varies from 4.2 to $6.2 \mathrm{~km} / \mathrm{s}$ (average = $5.4 \pm 0.1 \mathrm{~km} / \mathrm{s}$ ). A notable exception to the uniform velocity structure of the upper $500 \mathrm{~m}$ of basement occurs immediately below the massive ponded lava (Units 1256D-2 through 4c; 350-400 mbsf). Here, average velocity decreases $0.6 \mathrm{~km} / \mathrm{s}$ to $4.8 \mathrm{~km} / \mathrm{s}$ and variability increases from \pm 0.1 to $\pm 0.3 \mathrm{~km} / \mathrm{s}$. The ponded lavas have a slightly higher discrete sample $V_{\mathrm{p}}(5.5 \pm 0.1 \mathrm{~km} / \mathrm{s})$ than most of the rocks below, which have an average $V_{\mathrm{p}}$ of $5.4 \pm 0.1 \mathrm{~km} / \mathrm{s}$. Magnetic susceptibility varies from $\sim 0$ to $10,000 \times 10^{-5} \mathrm{SI}$ in the upper $500 \mathrm{~m}$ of Hole $1256 \mathrm{D}$ basement. The ponded lavas have an average magnetic susceptibility of $5100 \times 10^{-5} \pm 900 \times 10^{-5}$ SI, and below 350.3752 mbsf, magnetic susceptibility values increase systematically with depth, from $\sim 1000 \times 10^{-5}$ to 5000 $\times 10^{-5} \mathrm{SI}$, with an average magnetic susceptibility of $3000 \times 10^{-5} \pm 1800 \times 10^{-5}$ SI. Natural gamma ray measurements were rarely above background in the basement rocks from Leg 206, with the exception of a potassium-rich zone (Unit 1256C-18; 294-308 mbsf) in the massive ponded lava.

A full suite of logging tools was run in Hole 1256D following the completion of coring operations. The tools utilized, in order of deployment, were the triple combination (triple combo) tool string, the Formation MicroScanner (FMS)-sonic tool string, the Ultrasonic Borehole Imager (UBI), and the Well Seismic Tool (WST). Logging showed that Hole $1256 \mathrm{D}$ was in excellent condition with no constrictions or ledges. Caliper readings from both the triple combo and the FMS-sonic tool strings show the borehole diameter to be mostly between 11 and 14 inches, with only four short intervals $>16$ inches. The downhole measurements and images recorded show a large amount of variation, reflecting the massive units, lava flows, pillow lavas, and hyaloclastites recovered in Hole 1256D (Fig. F9).

\section{Predictions of depth to gabbros}

The recognition that there is a relationship between spreading rate and the depth to axial low-velocity zones, imaged by MCS experiments across the axes of mid-ocean ridges and thought to be axial melt lenses, is fundamental to the pursuit of the Superfast Spreading Rate Crust mission. Extrapolation of the depth to the axial low-velocity zones versus spreading rate relationship (Fig. F3) (Purdy et al., 1992) to a superfast spreading rate akin to that occurring during the accretion of crust at Site $1256 \sim 15$ m.y. ago on the EPR (200-220 mm/y; Wilson, 1996) indicates that the melt lens would have been located at depths between $\sim 725$ and $1000 \mathrm{~m}$ beneath the axis. As the new plate cools and moves away from the ridge axis, it will become buried by lavas that flow short distances down the ridge slope $(\sim 1-2 \mathrm{~km})$, as well as by larger lava bodies that flow significant distances $(\sim 5-$ $10 \mathrm{~km}$ ) off axis, such as the $>74 \mathrm{~m}$ thick massive lava pond (Units 1256C-18 and 1256D-1) that formed the upper crust at Site 1256 or similar features recognized on the modern EPR (e.g., Macdonald et al., 1989).

In planning Expedition 309/312, the depth to gabbros was estimated by assuming that the total thickness of near-axis and off-axis lavas was between 100 and $300 \mathrm{~m}$, giving a total estimated depth to gabbros of between 825 and 1300 msb (Fig. F11; Table T2). Our selection of 100-300 m of lava flows comes from a number of lines of evidence. MCS experiments on the EPR estimate Layer 2A thicknesses of $\sim 300 \mathrm{~m}$ in the near-axis region (Hooft et al., 1996; Carbotte et al., 1997a), although the geological nature of this seismic layer remains poorly understood. Stronger evidence comes from petrologic descriptions of the rocks from the uppermost basement at Site 1256 drilled during Leg 206. The very uppermost basement, designated during Expedition 309 as the "lava pond" (Units 1256C-1 through 18 and 1256D-1; 250-350.3 mbsf), comprises thin basaltic sheet flows a few tens of centimeters to $\sim 3 \mathrm{~m}$ thick (Units 1256C-1 through 17) overlying a massive ponded flow (Units $1256 \mathrm{C}-18$ and $1256 \mathrm{D}-1$ ) of $\sim 30$ to $\sim 74 \mathrm{~m}$ of fine-grained basalt in Holes $1256 \mathrm{C}$ and $1256 \mathrm{D}$, respectively (Wilson, Teagle, Acton, et al., 2003). Although the massive flow is much thicker in Hole $1256 \mathrm{D}$ than in $1256 \mathrm{C}$, it is interpreted as a single lava body whose interior was liquid at the same time in both locations. The dramatic increase in thickness over $30 \mathrm{~m}$ of lateral distance and a total thickness in excess of $74 \mathrm{~m}$ required at least this much paleotopography to pool the lava. On fast-spreading ridges, such topography does not normally develop until 5-10 km from the axis (e.g., Macdonald et al., 1989), and we suspect that these magmas flowed a significant distance off axis before ponding in a faulted depression.

Immediately underlying the lava pond is a sequence of massive flows, pillow lavas, and sheet flows (Units $1256 \mathrm{D}-2$ through $15 ; 350.3-533.9 \mathrm{mbsf}$ ) grouped together as the "inflated flows." Although rocks exhibiting a number of eruptive styles are included here, the critical criterion for this subdivision is the occurrence of subvertical elongate fractures filled with quenched glass and hyaloclastite (e.g., Sections 2061256D-21R-1 and 40R-1) at the top of the lava flows. 
These features indicate flow-lobe inflation, which requires eruption onto a subhorizontal surface with less than a few degrees slope (Umino et al., 2000, 2002); therefore, it is unlikely that such lavas formed on the ridge slope. Such inflation features are not observed in cores deeper in Hole 1256D. Taken together, the cumulative thickness of the lava pond and the inflated flows is $\sim 280 \mathrm{~m}$, close to our preferred estimate of $\sim 300 \mathrm{~m}$ for the thickness of offaxis lava flows.

Seismic data from site survey Cruise EW9903 offer significant clues about the expected downhole lithologic variations. The velocity-depth function inferred from seismic refraction (Fig. F7) (A. Harding, unpubl. data) shows a uniform gradient from $\sim 4.8$ $\mathrm{km} / \mathrm{s}$ at the sediment/basement interface to $5.3 \mathrm{~km} / \mathrm{s}$ at $\sim 600 \mathrm{msb}$, with the gradient then sharply increasing and velocity reaching $5.9 \mathrm{~km} / \mathrm{s}$ at $\sim 800 \mathrm{msb}$. The gradient abruptly returns to a moderate value, with velocity of $6.5 \mathrm{~km} / \mathrm{s}$ at $\sim 1250 \mathrm{msb}$. The gradient decreases gradually, with nearly uniform velocity of $\sim 6.8 \mathrm{~km} / \mathrm{s}$ between 2000 and $3000 \mathrm{msb}$. MCS reflection data (Fig. F6) (Hallenborg et al., 2003) show several nearly horizontal reflections with kilometers of horizontal extent to nearly $5.5 \mathrm{~s}$ traveltime, or $\sim 800$ $900 \mathrm{msb}$. For the upper $\sim 800 \mathrm{~m}$, the relatively lower velocities and horizontal reflection character suggest that flows constitute a substantial fraction of the uppermost crust at Site 1256. At greater depth, the decrease in velocity gradient below $\sim 1250$ msb marks the seismic Layer $2 / 3$ boundary. Unfortunately, the gradual nature of the change in gradient means that the depth of this transition cannot be assigned a depth more precisely than 1250-1500 msb. Whether this boundary corresponds the presence of gabbro remains to be tested.

\section{Scientific results}

Expedition 309, Superfast Spreading Rate Crust 2, successfully deepened Hole $1256 \mathrm{D}$ by $503 \mathrm{~m}$ to a total depth of $1255.1 \mathrm{mbsf}$, or $1005.1 \mathrm{msb}$. At the end of Expedition 309, Hole 1256D penetrated a total of $>750 \mathrm{~m}$ of extrusive lavas and proceeded a further $250 \mathrm{~m}$ into sheeted dikes. At $1255 \mathrm{mbsf}$, Hole 1256D was tantalizingly close to the predicted minimum estimated depth for the frozen axial magma chambers (1275 mbsf). Following the completion of a comprehensive wireline logging program, Hole 1256D was successfully exited and left clear of equipment with only minor unconsolidated fill at the bottom of the hole.

Expedition 309 (July-August 2005) was followed closely by Expedition 312, Superfast Spreading Rate Crust 3 (November-December 2005). During Expedi- tion 312 , Hole $1256 \mathrm{D}$ was deepened by $252.0 \mathrm{~m}$ to $1507.1 \mathrm{mbsf}$ (1257.1 msb), successfully achieving the main goal of the Superfast Spreading Crust mission, penetration through lavas and dikes into gabbros. The hole now extends through the $345.7 \mathrm{~m}$ thick sheeted dike complex and $100.5 \mathrm{~m}$ into gabbroic rocks. The latter were first encountered at 1406.6 mbsf, near the middle of the depth range predicted from geophysical observations (Fig. F12). A complete suite of wireline logging, including a vertical seismic profile, was carried out, and the hole remains clear and open for future drilling deeper into the plutonic foundation of the crust.

\section{Predrilling experiments during Expedition 309}

The first scientific operation of Expedition 309 was to deploy the wireline Water Sampling Temperature Probe (WSTP) to collect a sample of the fluid at the bottom of Hole 1256D and measure the ambient thermal conditions in the hole using the Advanced Piston Corer Temperature (APCT) and LamontDoherty Earth Observatory (LDEO) Temperature/ Acceleration/Pressure (TAP) tools. The WSTP was followed by wireline logging runs using the triple combo and FMS-sonic tool strings to assess the condition and caliper of the hole and check for borehole wall breakouts and unstable regions. There was $\sim 27$ $\mathrm{m}$ of loose fill in the bottom of Hole 1256D that precluded running the wireline tools to the full depth of the hole (752 mbsf).

The temperature profile made with the TAP tool on the triple combo tool string shows a steady increase in temperature from the base of the casing (269 mbsf) to a maximum temperature of $67.5^{\circ} \mathrm{C}$ recorded at the deepest logging depth ( 725 mbsf). Heat flow measured in the sedimentary section of Hole 1256B to a depth of $158 \mathrm{mbsf}$ was $113 \mathrm{~mW} / \mathrm{m}^{2}$ (Wilson, Teagle, Acton, et al., 2003). In the basement section in Hole $1256 \mathrm{D}$, thermal conductivity averaged 2.0 $\mathrm{W} /(\mathrm{m} \cdot \mathrm{K})$ in the ponded lava flow above $350 \mathrm{mbsf}$ and $1.7 \mathrm{~W} /(\mathrm{m} \cdot \mathrm{K})$ below $350 \mathrm{mbsf}$. For uniform heat flow of $113 \mathrm{~mW} / \mathrm{m}^{2}$ downhole, these conductivities predict a thermal gradient of $0.056 \mathrm{~K} / \mathrm{m}$ above 350 mbsf and $0.067 \mathrm{~K} / \mathrm{m}$ below 350 mbsf. These predictions are reasonably close to the observed gradients of 0.067 and $0.071 \mathrm{~K} / \mathrm{m}$, probably within uncertainties of the thermal conductivity measurements and the inevitable slight disturbance of the ambient hole temperature due to the passage of the drill string and wireline tools. This suggests that there is little advection of heat by fluid in the Site 1256 basement or major vertical fluid movements in Hole 1256D.

The $67.5^{\circ} \mathrm{C}$ deep borehole fluid collected from the bottom of Hole 1256D ( 725 mbsf) is chemically very 
distinct from seawater. Relative to Site 1256 bottom seawater, the borehole fluid is hotter, slightly more neutral ( $\mathrm{pH}=\sim 7.4)$, and has significantly lower alkalinity $(0.85 \mathrm{mM})$. Salinity is unchanged $(35 \%)$. The largest changes are in the concentrations of dissolved ions with major reductions in the concentrations of boron $(-18 \%)$, sulfate $(-19 \%)$, potassium $(-41 \%)$, lithium $(-47 \%)$, and magnesium (-55\%). In contrast, the strontium concentration is slightly increased (18\%) and the calcium content is very strongly elevated (415\%). The deep borehole fluid is also significantly different from the composition of the $\sim 35^{\circ} \mathrm{C}$ uppermost ( $250 \mathrm{mbsf})$ basement fluid estimated from pore water chemical gradients measured at Site 1256 during Leg 206 (Wilson, Teagle, Acton, et al., 2003). The deep borehole fluid has lower lithium $(-15 \%)$, magnesium $(-25 \%)$, and potassium $(-30 \%)$ concentrations but higher dissolved silica (14\%), sulfate $(84 \%)$, and calcium (122\%) concentrations relative to the uppermost basement fluid.

When the deep borehole fluid is compared to the well-characterized basement fluids from the eastern flank of the Juan de Fuca Ridge (Elderfield et al., 1999), most ions are present in concentrations similar to those predicted for a $67.5^{\circ} \mathrm{C}$ fluid. The exception is the $\mathrm{Mg}$ concentration of the deep borehole fluid, which at $\sim 24 \mathrm{mM}$ is higher than would be expected for a fluid reacted with basement at $>60^{\circ} \mathrm{C}$. The disagreement between the concentration of $\mathrm{Mg}$ in hot deep borehole fluids and that predicted from uppermost basement fluids or laboratory experiments has previously been noted for wireline fluid samples recovered from Hole 504B (e.g., Becker, Foss, et al., 1992). However, the chemistry of the deep borehole fluid from Hole 1256D is closer to equilibrium than the most pristine borehole fluids, which were taken from the deepest available points in Hole 504B during the different drilling expeditions there. Those fluids have $\mathrm{Mg}$ concentrations similar to those of the uppermost basement fluid at Site 504. In contrast, the fluid from the bottom of Hole 1256D has $\mathrm{Ca}$ (and Li and K) concentrations close to those expected for a fluid in chemical equilibrium with $67.5^{\circ} \mathrm{C}$ basement and, unlike Hole $504 \mathrm{~B}$, the $\mathrm{Mg}$ concentration is at least partially decreased toward the predicted composition.

The primary purpose of the initial logging operations was to check Hole $1256 \mathrm{D}$ for borehole wall breakouts and variations in hole diameter though comparison with measurements made at the end of Leg 206. The initial phase of wireline logging indicated that, before the commencement of drilling, borehole conditions in Hole 1256D were excellent, and no ledges or obstructions were encountered. Caliper readings from both the triple combo and
FMS-sonic tool strings show good borehole conditions, with a diameter typically between 10 and 12 inches. The FMS-sonic tool string followed a different pathway during the Expedition 309 pass compared with the Leg 206 passes, and consequently, in many intervals the FMS image coverage of the borehole wall has increased. Sonic velocities measured by the Dipole Sonic Imager appear to be of high quality. Several narrow zones (at 517, 597, 602, and 685 mbsf) with strong differences in the orthogonally arranged calipers on the FMS-sonic tool string were identified during both Leg 206 and Expedition 309. These intervals may correspond to borehole breakouts, and the north-south orientation of the borehole enlargements suggests a west-east maximum stress direction. A tight spot recognized during Leg 206 at 486 mbsf was also recorded during the Expedition 309 predrilling passes, and a new zone was identified at 472 mbsf (9.3 inches).

\section{Ocean crust formed at superfast spreading rate: deep drilling the ocean basement in Hole 1256D}

During Expedition 309, Hole 1256D was reentered with a rotary core barrel (RCB) assembly and C-9 coring bit at $2325 \mathrm{~h}$ on 18 July 2005 , and $\sim 27 \mathrm{~m}$ of loose fill was cleared from the bottom of the hole so that it was open to the full depth achieved during Leg 206 (752 mbsf; $502 \mathrm{msb}$ ). Rotary coring of the basement continued until 20 August ( 33 days), when the hole was conditioned for wireline logging operations. A total of nine C-9 RCB hard-formation coring bits were used, and Hole 1256D was deepened by $\sim 503 \mathrm{~m}$ to $1255.1 \mathrm{mbsf}$ ( 1005.1 msb; Cores 309-1256D-75R through 170R).

Hole $1256 \mathrm{D}$ was reentered at $2030 \mathrm{~h}$ on 15 November 2005 during Expedition 312. Following 51/2 days of remedial washing and reaming, the hole was opened and cleared of debris to the depth reached during Expedition 309. Rotary coring of basement proceeded for $\sim 23$ days, interrupted by $\sim 5$ days of fishing and milling when the cones were lost from a C-7 RCB coring bit. A total of seven RCB coring bits (six C-9 and one C-7) were used, and the hole was deepened by $252.0 \mathrm{~m}$ to $1507.1 \mathrm{mbsf}(1257.1 \mathrm{msb})$, reached at $0250 \mathrm{~h}$ on 19 December. The hole was then prepared for a full suite of wireline logging. Logging tools did not penetrate past 1432 mbsf (1182 msb), indicating an obstruction $\sim 75 \mathrm{~m}$ above the bottom of the hole. The hole was exited cleanly and remains open for further drilling.

Core recovery averaged 36\% in Hole 1256D, with the highest rates in the lava pond and the lowest rates in the lowermost dikes (Table T3; Figure F13). Rate of 
penetration (ROP) varied similarly, with the highest rates in the lavas and the lowest rates in the lower dikes.

At $1257.1 \mathrm{msb}$, Hole $1256 \mathrm{D}$ is the fourth deepest hole drilled into oceanic basement since the launch of scientific ocean drilling in 1968 and the second deepest penetration into in situ ocean crust (Fig. F14). Hole 504B, deepened during seven DSDP and ODP legs into $6.9 \mathrm{Ma}$ crust on the southern flank of the intermediate-spreading Costa Rica Rift, remains the deepest penetration of in situ ocean crust. Prior to Expedition 309/312, Hole 504B was the only hole to sample a complete sequence of extrusive rocks as well as the transition from extrusive rocks to sheeted dikes (Alt, Kinoshita, Stokking, et al., 1993).

\section{Preliminary subdivision of the upper oceanic crust at Site 1256}

To facilitate description and discussion of the crustal stratigraphy at Site 1256 and assist in the interpretation of cores recovered during Expedition 309/312, we present a subdivision of the upper crust sampled so far in Hole 1256D (Table T4; Fig. F15). Detailed descriptions are presented in the following sections.

The upper crust at Site 1256 can be portioned into six basement subdivisions, which, in descending order down the hole, are the lava pond, inflated flows, sheet and massive flows, transition zone, sheeted dikes, and plutonic section (Table T4).

\section{Lava pond}

The lava pond caps the uppermost crust at Site 1256. This domain includes Units 1256C-1 through 18 and 1256D-1 ( 250-350.3 mbsf). The uppermost lavas were not recovered in Hole 1256D because 16 inch casing was set $19.5 \mathrm{~m}$ into basement and the interval was not cored. In Hole 1256C, the rocks immediately below the sediments comprise thin basaltic sheet flows a few tens of centimeters to $\sim 3 \mathrm{~m}$ thick separated by chilled margins and rare intervals of recrystallized sediment (Units 1256C-1 through 17). The massive ponded flow, sensu stricto (Units 1256C-18 and $1256 \mathrm{D}-1)$, is defined at its top by a $\sim 75 \mathrm{~cm}$ rind of glassy to cryptocrystalline aphyric basalt that overlies $\sim 30$ and $\sim 74 \mathrm{~m}$ of fine-grained basalt in Holes $1256 \mathrm{C}$ and $1256 \mathrm{D}$, respectively. The massive ponded flow becomes abruptly cryptocrystalline $\sim 1.5 \mathrm{~m}$ above its base. Although the massive flow is much thicker in Hole 1256D than in 1256C, it is interpreted as a single lava body whose interior was liquid at the same time in both locations. The dramatic increase in thickness over $30 \mathrm{~m}$ of lateral distance and a total thickness in excess of $74 \mathrm{~m}$ indicates that there was at least this much paleotopography in order to pool the lava. On fast-spread- ing ridges, such topography does not normally develop until $\sim 5-10 \mathrm{~km}$ from the axis (e.g., Macdonald et al., 1989), and we suspect that these lavas flowed a significant distance off axis before ponding in a faulted depression.

\section{Inflated flows}

Immediately underlying the lava pond is a sequence of massive flows, pillow lavas, and sheet flows (Units $1256 \mathrm{D}-2$ through $15 ; 350.3-533.9 \mathrm{mbsf}$ ) grouped together as the inflated flows. Although rocks exhibiting a number of eruptive styles are included here, the criterion for subdivision is the occurrence of subvertical elongate fractures filled with quenched glass and hyaloclastite (e.g., Sections 206-1256D-21R-1 and 40R-1) at the top of the lava flows. These features indicate flow-lobe inflation that requires eruption onto a subhorizontal surface at less than a few degrees (Umino et al., 2000, 2002), suggesting offaxial flows.

\section{Sheet and massive flows}

The bulk of the extrusive lavas at Site 1256 are included in the sheet and massive flows (Units 1256D16 through 39b; 533.9-1004.2 mbsf). A total of 218 $\mathrm{m}$ of this subdivision was drilled during Leg 206, with a further $252 \mathrm{~m}$ of penetration during Expedition 309. This sequence consists of sheet flows tens of centimeters to $\sim 3 \mathrm{~m}$ thick with subordinate massive flows $>3$ to $16 \mathrm{~m}$ thick and uncommon breccias. The flows are aphyric to sparsely phyric, cryptocrystalline to microcrystalline basalts. Units are distinguished by the presence of chilled margins or by grain-size variations. Throughout this interval, glassy chilled margins are common.

\section{Transition zone}

It is the very essence of a transitional sequence that boundaries are loosely defined and subjective. In Hole 1256D, the transition zone from Units 1256D40 through $44 \mathrm{a}$ (1004.2-1060.9 mbsf) is identified by the occurrence of a number of criteria and different rock types as opposed to the appearance of one specific feature. Shore-based analysis of wireline logs and further petrographic and geochemical investigations will help refine the boundaries of this zone. Most of the rocks within the transition zone are aphyric, cryptocrystalline sheet flows. The top of the transition zone is marked by a cataclastic massive unit (Section 309-1256D-117R-1, 85 cm). This comprises subvertically oriented cryptocrystalline basalt clasts hosted within a very highly altered finegrained basalt that has been incipiently brecciated and deformed along numerous fine veins and cataclastic stringers. Core 309-1256D-120R ( 1018 mbsf) 
includes the first sign of a subvertical intrusive contact other than the single occurrence further upcore in Section 206-1256D-32R-2 at $\sim 475$ mbsf. Dike chilled margins become more common downhole, although extrusive textures and vesicles are still encountered. It should be noted that subvertical fracture sets possibly indicative of diking into the host rocks near Hole 1256D are common from $~ 900$ mbsf. Breccias of various styles are common in the transition zone, including a spectacular mineralized volcanic breccia that comprises Unit 1256D-42a (interval 309-1256D-122R-1, $20 \mathrm{~cm}$, to $122 \mathrm{R}-2,30 \mathrm{~cm}$; $\sim 1028 \mathrm{mbsf}$ ). In the transition zone, secondary mineral assemblages (chlorite-smectite, albite, chlorite, actinolite, anhydrite \pm minor prehnite, epidote, and laumonite) indicative of hydrothermal alteration at subgreenschist to greenschist facies temperatures start to become more common.

\section{Sheeted dikes}

Hole $1256 \mathrm{D}$ penetrates a $345.7 \mathrm{~m}$ thick sheeted dike complex from 1060.9 to 1406.6 mbsf (Units 1256D$44 \mathrm{a}$ through $80 \mathrm{~b}$ ). The upper boundary is defined by a change from sheet flows to massive basalts (in Unit 1256D-44a, Core 309-1256D-129R). Below that level, subvertical intrusive contacts are common, and these can be sharp or irregular and lobate, the latter style indicating the intrusion of magma into hypersolidus rocks (e.g., Section 309-1256D-149R-1, 30-97 $\mathrm{cm} ; 1156 \mathrm{mbsf}$ ). Extrusive rocks may be present below 1060.9 mbsf, but there are no unambiguous indicators of eruption. Groundmass grain sizes vary from glassy to microcrystalline to fine grained with holocrystalline doleritic textures. No fresh glass was found in the sheeted dikes, but altered glass is present along some dike chilled margins and associated breccias in the upper half of the dike section. There is a step change in physical properties downward into the sheeted dikes, with significant increases in average thermal conductivity (from $1.8 \pm$ 0.2 to $2.1 \pm 0.1 \mathrm{~W} /[\mathrm{m} \cdot \mathrm{K}])$ and seismic velocity $(5.4 \pm$ 0.3 to $5.9 \pm 0.1 \mathrm{~km} / \mathrm{s})$. The average porosity of massive units decreases from $4 \% \pm 1 \%$ to $2 \% \pm 1 \%$ across the 1060.9 mbsf boundary. Subvertical contacts that grade continuously from glassy chilled margins to microcrystalline to fine-grained massive basalt were not recovered from the upper half of the sheeted dikes cored during Expedition 309 but are common in the lower portion from Expedition 312. Greenschist and subgreenschist minerals occur in the upper dikes, and alteration intensity and grade generally increase downhole in the dikes below 1300 mbsf. The amount of recrystallization and the abundance of actinolite increase below this depth, and secondary plagioclase and hornblende first appear in small amounts below $\sim 1350$ mbsf.

\section{Granoblastic dikes}

In the lower portion of the sheeted dikes, from 1348.3 to 1406.6 mbsf (Units 1256D-78 through $80 \mathrm{~b})$, the rocks are highly to completely altered and are locally recrystallized to granoblastic textures, leading to their designation as the granoblastic dikes. These rocks contain irregularly distributed local granoblastic patches, where the rock is completely recrystallized to secondary plagioclase and equant secondary clinopyroxene, magnetite, ilmenite, and rare orthopyroxene. The mineralogy and textures indicate recrystallization at high temperatures.

\section{Plutonic section}

The first gabbroic rocks were encountered at 1406.6 mbsf (Unit 1256D-81), where plutonic rocks intruded the overlying sheeted dikes. The plutonic section extends from 1406.6 mbsf to the bottom of the hole at 1507.1 mbsf (Units 1256D-81 through 95). This section consists of a $52.3 \mathrm{~m}$ thick Gabbro 1 unit (1406.6-1458.9 mbsf; Units 1256D-81 through 89b) and a $24 \mathrm{~m}$ thick Gabbro 2 unit (1483.1-1507.1 mbsf; Units 1256D-91 through 95) that are intrusive into metamorphosed basaltic dikes. The gabbroic rocks are fine to coarse grained (mostly medium grained) and range from gabbro to disseminated oxide gabbro, oxide gabbro, orthopyroxene-bearing gabbro, gabbronorite, trondjhemite, and quartz-rich oxide diorite (or FeTi diorite). The rocks are highly altered to amphibole, chlorite, plagioclase, titanite, and minor laumontite and epidote, with chlorite and epidote more abundant in the Gabbro 2 unit. Stoped basalt fragments are common in Gabbro 2.

The two gabbro units are separated by a $24.2 \mathrm{~m}$ thick dike screen (Unit 1256D-90a), consisting of finegrained, highly to completely altered cryptocrystalline basalt dikes. These rocks commonly display granoblastic textures like those in the basal sheeted dikes. At the base of the drilled section is a $12.1 \mathrm{~m}$ thick gabbronorite unit of uncertain origin (Unit 1256D-94 through 95). This may be a metabasalt derived from younger sheeted dikes or a fine-grained intrusive gabbronorite. This lowermost section of the hole also contains a late basalt dike (Unit 1256D-95; $1502.6 \mathrm{mbsf}$ ) that does not exhibit granoblastic texture or other evidence of high-temperature metamorphism associated with gabbro intrusion.

\section{Igneous petrology}

Basement rocks recovered during Expedition 309/ 312 in Hole $1256 \mathrm{D}$ from 752 to $1507.1 \mathrm{mbsf}$ were divided into 69 igneous units (1256D-27 through 95), labeled continuously from the last rocks recovered during Leg 206 (Table T4; Fig. F16) (Wilson, Teagle, Acton, et al., 2003). 


\section{Sheet and massive flows}

The sheet and massive flows (Units 1256D-16 through 39 ; 533.9-1004.2 mbsf) are mainly composed of sheet flows and massive flows. Sheet flows (with individual cooling units ranging from tens of centimeters to $<3 \mathrm{~m}$ thick) make up $80 \%$ of the total sheet and massive flows cored during Leg 206 and Expedition 309. However, in the portion of this subdivision drilled during Expedition 309, sheet flows account for only $65 \%$ of the rock recovered, indicating a prevalence of massive flows deeper in the section. Individual flows are commonly separated by chilled margins containing altered or fresh glass. Where contacts were not recovered, individual flows can be distinguished by systematic changes in grain size. Using these criteria, minimum thicknesses of individual flows or cooling units range between 0.11 and $1.68 \mathrm{~m}$ with an average thickness of $0.55 \pm 0.35$ $\mathrm{m}$. The flows are predominantly aphyric $(<1 \%$ phenocrysts), and grain size ranges from glassy at the chilled margins to cryptocrystalline or microcrystalline (Fig. F17). Rare sheet flow interiors are fine grained. The groundmass of sheet flows generally consists of plagioclase and clinopyroxene microlites, with interstitial titanomagnetite and altered glass, similar to those described during Leg 206. Where phenocrysts occur (for example, in Units 1256D-28, $35 \mathrm{~b}$, and 37), these rocks have plagioclase, clinopyroxene, and olivine phenocrysts, in order of decreasing abundance, commonly clustered in a glomeroporphyritic texture (Fig. F18). Unit 1256D-35c contains three small $(0.5-2.2 \mathrm{~cm})$ holocrystalline gabbroic xenoliths (intervals 309-1256D-107R-1, 44$52 \mathrm{~cm}, 108 \mathrm{R}-1,20-36 \mathrm{~cm}$, and 108R-1, 132-138 cm) consisting of fine-grained olivine, plagioclase, and clinopyroxene (Fig. F19).

In contrast to the thinner sheet flows, minimum thicknesses of the massive flow units vary from 3.2 to $11.3 \mathrm{~m}$ with an average of $6.3 \mathrm{~m}$ (cumulative thickness calculated using only the pieces recovered). The thickest, Unit 1256D-31, consists of a single cooling unit of fine-grained basalt below a $12 \mathrm{~cm}$ cryptocrystalline to microcrystalline upper contact (Fig. F20). A total of $26 \mathrm{~m}$ of this unit was cored, of which $11.3 \mathrm{~m}$ was recovered. In contrast to the sheet flows, fine-grained rocks are more common in the massive lavas (Fig. F16). The massive flows are aphyric and nonvesicular, with the exception of Unit 1256D-39a. This basalt is sparsely clinopyroxeneolivine-plagioclase-phyric and is moderately vesicular (8\%) (Fig. F21). Thin section observations show that the most finely grained rocks collected from the massive flows have intergranular to intersertal groundmass textures (Fig. F22).

\section{Transition zone}

The transition zone (Units 1256D-40 through 43; 1004.2-1060.9 mbsf) is characterized by increasing abundance of volcanic breccias interbedded within sheet flows. The top of this zone is defined by the cataclastic massive unit (1256D-40; interval 3091256D-117R-1, $85 \mathrm{~cm}$, through 118R-1, $66 \mathrm{~cm}$ ). The upper part of this unit (interval 309-1256D-117R-1 [Pieces 9-14, 97-142 cm]) has a complex structure with fine- to medium-grained basalt in contact with brecciated clasts of cryptocrystalline basalt (Fig. F23). The fine- to medium-grained basalt contains highly altered glass clasts and is disrupted by an intensive network of thin chlorite-smectite veins imparting an incipient cataclastic texture. Thin section examination of these rocks (Sample 309-1256D-117R-1, 122$125 \mathrm{~cm}$ ) shows that fractured crystals have a seriate texture, deformed and cemented by a banded matrix that shows flow structures. With increasing distance below the top of the unit, the igneous texture is better preserved and more homogeneous, mesostasis is less abundant, and crystals are less fractured (interval 309-1256D-117R-2, 9-72 cm, through 118R-1, 0-66 $\mathrm{cm})$. In this lower part of Unit 1256D-40, the cataclastic massive unit consists of fine-grained dolerite with a partially developed subophitic texture (interval 309-1256D-117R-2, 23-26 cm). A few pieces, similar to the disrupted rocks of the upper part of this cataclastic unit, occur in intensively veined sheet flows in Units 1256D-37 and 41. This may support the interpretation that these disrupted rocks indicate the nearby presence of a dike or fault zone. Interval 309-1256D-120R-1, 9-26 cm, of the transition zone, however, captures the first unambiguous subvertical intrusive contact.

A second type of breccia is present in interval 3091256D-122R-1, $25 \mathrm{~cm}$, through 123R-1, $109 \mathrm{~cm}$, where $2.8 \mathrm{~m}$ of mineralized volcanic breccia and breccia intercalated with basalt was recovered and defines Unit 1256D-42 (Fig. F24). This unit can be further subdivided based on abundance of basaltic rocks. The upper part, Unit 1256D-42a, consists solely of volcanic breccia (interval 309-1256D-122R$1,25-149 \mathrm{~cm}$, through $122 \mathrm{R}-2,0-30 \mathrm{~cm}$ ), but in Unit $1256 \mathrm{D}-42 \mathrm{~b}$, the breccias are intercalated with aphyric, cryptocrystalline to microcrystalline basaltic sheet flows. These breccias comprise angular to subangular aphyric cryptocrystalline basaltic clasts (0.5$4.5 \mathrm{~cm}$ ) and subangular to elongate clasts of altered glass with rare flame-shape clasts $(0.1-1.5 \mathrm{~cm})$, cemented by chalcedony, saponite, calcium carbonate, albite, anhydrite, and sulfides (Fig. F24).

The transition zone also hosts the last occurrence of a glassy margin not associated with either a dike contact or clastic brecciation. This margin was recovered 
in the lower half of sheet flow Unit 1256D-43 ( 1060 mbsf).

\section{Sheeted dikes}

The upper boundary of the sheeted dikes (Units 1256D-44 through 65; 1060.9-1406.6 mbsf) is defined by a distinct change from sheet flows to massive basalts at 1060.9 mbsf. Extrusive rocks could be present in the upper portion of this section, but there is no conclusive evidence of extrusive origin for any of the units in the upper portion of this section. The massive basalts are most commonly aphyric and nonvesicular. Most rocks at depths $<1255$ mbsf are microcrystalline (Units 1256D-44 through 46,49 through 50, 52a, 54 through 55, and 59 through 65). Fine-grained rocks are less common (Units 1256D-47, 48, 51, and 53a), and rare units are cryptocrystalline to microcrystalline (Units 1256D$56 \mathrm{a}, 57 \mathrm{a}$, and 58) basalt. In thin section, the massive basalts are holocrystalline with predominantly intergranular textures (Fig. F25), ranging to intersertal and, occasionally, subophitic. No basaltic units in the sheeted dikes above 1255 mbsf show gradations from a chilled margin through crypto- and microcrystalline rock to fine grained material, whereas such gradations are common at deeper levels of the dikes.

Between 1255 and 1406 mbsf, we recovered aphyric fine-grained to microcrystalline basalts with some cryptocrystalline intervals. This interval is divided into 15 lithologic units (1256D-66 through 80; 1255-1406 mbsf), based primarily on abrupt changes in texture and/or grain size. Three subvertical intrusive contacts were recovered from unit boundaries in this zone (Units 1256D-68/69, 75/76, and 80/81) (Fig. F26), in addition to cryptocrystalline material at the Unit 1256D-77/78 boundary and in Unit 1256D71 , which most likely represents the contact between Units 1256D-70 and 72. Three other units (1256D70, 71, and 73) have internal contacts. In addition, several near-complete cooling units grade from cryptocrystalline margins to fine-grained centers and back to cryptocrystalline margins. Together, these lithologic data indicate that there are at least 9 individual dikes among the 15 sheeted dike units below 1255 mbsf (Fig. F27).

Subvertical intrusive dike contacts are common in the sheeted dike complex. In general, two types of contacts can be distinguished: sharp or irregular direct contacts and brecciated contacts. Most contacts belong to the latter category, with brecciated zones one to several centimeters wide along the contact. All contacts have developed chilled margins. The chilled margins of the dikes are composed of glassy to cryptocrystalline aphyric basalts that have quenched against cryptocrystalline to fine-grained, massive basaltic hosts. Glassy material is common at chilled margins above 1255 mbsf but is less abundant at greater depths. Breccias at the contacts in the upper dike section (<1255 mbsf) comprise fragments of altered glass initially quenched at the chilled margin with subordinate, angular to subangular clasts of the host rock and cemented by anhydrite, chlorite, and sulfide (Fig. F28). One spectacular example is a $>50 \mathrm{~cm}$ long vertical contact in interval 309-1256D140R-1, 26-80 cm (Unit 1256D-47), with a sulfideimpregnated dike margin breccia with complex intrusive relationships and intricate multiple marginparallel sulfide veins crosscut by anhydrite veins. Below 1255 mbsf, brecciated dike margins contain chlorite, amphibole, oxides, quartz, and sulfides filling fractures, and in some cases contain highly altered material that may be altered xenoliths.

In interval 309-1256D-155R-1 (Piece 20, 84-90 cm), the chilled margin forms a convex lobe, indicating that the host rock was not rigid during the intrusion (Fig. F29A). Further evidence for multiple intrusions is seen in Sections $309-1256 \mathrm{D}-161 \mathrm{R}-1$ to $161 \mathrm{R}-2$ (Unit 1256D-56b), where at least two intrusions are present. An inner sparsely clinopyroxene-olivineplagioclase phyric dike has intruded a sparsely clinopyroxene-olivine-plagioclase-phyric spherulitic cryptocrystalline rock, itself chilled against an aphyric microcrystalline host rock (Fig. F29B). Another example of dike intrusion into a ductile host rock is observed in interval 309-1256D-163R-1, 113-122 cm. This contact is lobate and highly complex with fractured pieces of the chilled margin dispersed in the host rock (Fig. F29C).

The overall mineralogical characteristics of basaltic basement drilled during Expedition 309/312 are similar to overlying Leg 206 basalts, although there are some important differences. More than $60 \%$ of the basalts drilled during Leg 206 are sparsely phyric with olivine, plagioclase, and clinopyroxene phenocrysts (Wilson, Teagle, Acton, et al., 2003), and aphyric rocks comprise $<40 \%$ of the Leg 206 basalts. In contrast, the vast majority of basalts recovered during Expedition 309/312 are aphyric (>80\%) (Figs. F16, F30). This difference is demonstrated by the downhole variation of phenocryst contents and by a decrease with depth of the total phenocryst content (Fig. F16). More than half of Leg 206 basalts have three major phenocryst phases (clinopyroxene, olivine, and plagioclase), whereas only rare samples (eight) of the Expedition 309/312 basalts have more than two phenocryst phases (Figs. F16, F30). Phenocryst-bearing basalts collected during Leg 206 are dominantly olivine-phyric ( $>80 \%)$, whereas in those from Expedition 309/312, plagioclase is the most 
common phenocryst phase and olivine is the least abundant among the three phenocryst phases (Figs. F16, F30). The different observation teams during Leg 206 and Expedition 309 may account for some of this difference, but such bias should be relatively minor. The general change from sparsely phyric to aphyric and from dominantly olivine to plagioclase phenocrysts appears to be a genuine downhole trend. A second trend is that sheeted dike basalts recovered below 1255 mbsf during Expedition 312 are predominantly fine grained, whereas those from Expedition 309 above 1255 mbsf are predominantly microcrystalline.

All basalts of the sheeted dike complex have been hydrothermally altered. The uppermost units are partially altered to subgreenschist to greenschist minerals, but the intensity and grade of metamorphism increase downhole. Beginning at $1348.3 \mathrm{mbsf}$, the basalts are highly to completely altered to amphibole-bearing assemblages with localized domains characterized by secondary clinopyroxene and lesser orthopyroxene. These domains typically exhibit granoblastic textures (Fig. F31), and their onset defines the "granoblastic dike" interval (1348.3-1406.6 mbsf) at the base of the sheeted dike complex.

\section{Plutonic section}

At 1406.6 mbsf in Hole 1256D, we encountered a gabbro dike, marking the end of the sheeted dike complex and the beginning of the $100.5 \mathrm{~m}$ thick plutonic section, which extends to 1507.1 mbsf. Intrusive relationships show that the plutonic section is the product of a series of discrete magmatic events beginning with the emplacement of an unknown number of sheeted dikes. At least two gabbro bodies intruded this sheeted dike sequence, followed some time later by a small crosscutting basalt intrusion at the base of the drilled section.

The plutonic section of Hole 1256D includes two medium-grained gabbroic intervals: Gabbro 1 (1406.6-1458.9 mbsf; Units 1256D-81 through 89) and Gabbro 2 (1483.1-1507.1 mbsf; Units 1256D-91 through 95) (Fig. F16). These gabbroic units are intrusive into the basal dikes of the sheeted dike complex and are responsible for the contact metamorphic effects in the granoblastic dikes. Gabbro 1 and Gabbro 2 are separated by the dike screen (1458.91483.1 mbsf; Unit 1256D-90), a granulite-grade metabasalt interval with a well-developed granoblastic metamorphic texture and containing secondary clinopyroxene and orthopyroxene.

With the exception of a narrow $(<1 \mathrm{~m})$ quartz-rich oxide diorite dike that is compositionally equivalent to an oceanic FeTi basalt (Unit 1256D-82), Gabbro 1 is mineralogically uniform but texturally heteroge- neous (Fig. F32). It is divided into eight units (1256D-81 and 83 through 89 ), primarily on the basis of variations in dominant texture and/or grain size. Gabbro 1 gabbros are commonly oxide bearing, and oxide abundance decreases irregularly downhole. Olivine is present in significant amounts only in the lower two units (1256D-88 and 89).

Gabbro 2 consists of three separate igneous intervals: an upper medium-grained orthopyroxene-bearing gabbro that grades to gabbronorite near its margins (Units 1256D-91 through 93), a fine-grained gabbronorite of which the origin is unclear (Unit 1256D-94), and a later basaltic crosscutting intrusion (Unit 1256D-95). The upper orthopyroxene-bearing gabbro interval of Gabbro 2 is characterized by an absence of fresh olivine, high but variable orthopyroxene contents (5\%-25\%) and considerable local heterogeneity (Fig. F33). Oxides are present throughout, mostly up to $5 \%$ and rarely higher. Oxide abundance generally diminishes downhole. At the upper margin of this zone, gabbronorite intrudes and invades the metabasalt of the dike screen, isolating and detaching centimeter-sized blocks of metabasalt (Fig. F34). Similar detached blocks of pinkish orthopyroxene-rich cryptocrystalline to fine-grained metabasalt are also present close to a lower contact, at the base of Unit 1256D-93.

Below the medium-grained orthopyroxene-bearing gabbro of Gabbro 2 is a fine-grained "gabbronorite" of uncertain origin (Unit 1256D-94). It is extensively recrystallized with well-developed granoblastic textures, although relict igneous, intergranular textures are preserved in some places, especially away from the upper boundary. There is some ambiguity as to whether this unit is a metabasalt or a fine-grained intrusive gabbronorite. The textures of rocks from Unit 1256D-94 are similar to those from Unit 1256D-90 of the dike screen, and both of these units appear to show an increase in modal orthopyroxene at their contacts with the orthopyroxene-bearing gabbro.

The last unit recovered during Expedition 312, Unit $1256 \mathrm{D}-95$, begins at 1502.6 mbsf. Unit $1256 \mathrm{D}-95$ is a relatively light gray cryptocrystalline basalt that is distinguished by the presence of abundant pink clinopyroxene (titanaugite?) and by its relatively low primary oxide content. It is also distinct from the other basaltic rocks of the plutonic section in its relatively low metamorphic grade well-preserved igneous texture and relatively low degree of alteration, which are roughly equivalent to those of much shallower units around Unit 1256D-70. We interpret this unit as a crosscutting, relatively enriched basalt dike or sill that intruded after significant cooling had occurred. 


\section{Geochemistry}

The freshest rocks from each igneous unit were selected for elemental analysis by shipboard inductively coupled plasma-atomic emission spectroscopy (ICP-AES) (Fig. F35). All samples from Expedition 309 have compositions within the range of MORB with $\mathrm{SiO}_{2}=48-55 \mathrm{wt} \%, \mathrm{FeO}=9.4-14.0 \mathrm{wt} \%, \mathrm{MgO}=$ 6.2-8.9 wt $\%, \mathrm{CaO}=7.1-12.8$ wt $\%, \mathrm{Na}_{2} \mathrm{O}=1.8-5.0$ wt $\%, \mathrm{Cr}=21-367 \mathrm{ppm}, \mathrm{Sr}=71-129 \mathrm{ppm}, \mathrm{Zr}=56-$ $133 \mathrm{ppm}$, and $\mathrm{Ba}=1-37 \mathrm{ppm}$. The range of the $\mathrm{Mg \#}$ is $45-62$ (average $=53$ ). These values broadly overlap the results from Leg 206 (Fig. F36) and correspond to typical values for MORB (Su and Langmuir, 2003). Analyses of cryptocrystalline basalts from Expedition 309 that are unambiguously dikes are chemically indistinguishable from massive basalts into which these dikes were intruded. There do not appear to be any systematic geochemical differences between sheet flows, massive flows, and dikes (Fig. F35).

Drilling in Hole 1256D during Expedition 312 recovered basaltic dikes, gabbros, quartz-oxide diorite, and a trondjhemite dike. Several rocks recovered from the junk baskets during mill runs were analyzed and are labeled as "ghost cores." The rocks fell into the bottom of the hole, so it is unknown at what depth the rocks originated. Basaltic dikes recovered from the sheeted dike complex during Expedition 312 have variable contents of major and trace elements and span nearly the entire range of rocks cored from higher in the hole. However, new minima for $\mathrm{Zn}$ and $\mathrm{V}$ concentrations and maxima for $\mathrm{Ni}$ and $\mathrm{Cr}$ abundances are found in two analyses of the sheeted dikes. Most dikes fall along a fractional crystallization trend defined by rocks from Hole 1256D. Although there is considerable scatter in the data, linear magmatic fractionation trends are present for $\mathrm{TiO}_{2}, \mathrm{FeO}, \mathrm{CaO}, \mathrm{Na}_{2} \mathrm{O}$, and $\mathrm{Zr}$ versus $\mathrm{MgO}$ (Fig. F36). This trend appears to be largely controlled by the fractional crystallization of clinopyroxene and plagioclase (Fig. F37), suggesting these rocks are fairly evolved.

There are subtle variations in the basalt chemistry downhole, with a number of step changes or reversals of fractionation trends possibly indicating cycles of fractionation, replenishment, and, perhaps, assimilation (e.g., at $\sim 600,750,908$, and 1125 mbsf). However, dike compositions from Expedition 312 are variable and do not define obvious trends downhole.

Gabbros in the plutonic section were recovered in two sequences, separated by a dike screen (Table T4). Gabbros from Gabbro 1 have variable chemical compositions ranging from more fractionated at the top of the sequence toward less evolved deeper down. The lowermost gabbro from the Gabbro 1 sequence has high $\mathrm{MgO}(11.4 \mathrm{wt} \%)$ and in thin section appears to have accumulated olivine. The Gabbro 2 sequence contains generally more fractionated rocks than Gabbro 1; however, there is again a general trend toward less evolved compositions downcore. For example, $\mathrm{TiO}_{2}$ is $2.5 \mathrm{wt} \%$ at the top of Gabbro 2 and $1.2 \mathrm{wt} \%$ at the base and $\mathrm{FeO}$ is $16.4 \mathrm{wt} \%$ at the top and $\sim 10 \mathrm{wt} \%$ at the bottom (Fig. F35). Therefore, systematic fractional crystallization occurred in these gabbros, although their lithofacies are very heterogeneous.

Only two of the leucocratic rocks recovered during Expedition 312 were analyzed. The first leucocratic rock encountered was a thin dike within a basaltic dike unit. This rock has high silica (72 wt\%) and $\mathrm{Zr}$ ( $840 \mathrm{ppm})$, low $\mathrm{TiO}_{2}$ and $\mathrm{FeO}$, and is unlike any other rock from Hole $1256 \mathrm{D}$. Chemically and petrographically, it is a trondjhemite and likely a very late-stage liquid remaining after extensive fractionation took place in the melt lens. The second leucocratic rock recovered was a quartz-rich oxide diorite. This unit has unusual geochemical characteristics with very high $\mathrm{FeO}$ and $\mathrm{TiO}_{2}$ contents and is similar to an evolved FeTi basalt.

Similar to analyses of basalts from Leg 206, Ti and Y in basaltic rocks from Expedition 309/312 show good positive linear correlations with $\mathrm{Zr}$, due to their similar geochemical behavior (Fig. F38). Leg 206 basalts above 750 mbsf were classified into three groups based on a distinct gap in the Ti-Zr concentration: high Zr-Ti, low Zr-Ti, and high Zr. With additional data analyzed during Expedition 309/312, this data gap disappears and the three-fold subdivision is probably not valid. Rare samples from the inflated flows in Hole 1256D fall off the $\mathrm{Y}$ versus $\mathrm{Zr}$ and $\mathrm{Ti}$ versus $\mathrm{Zr}$ trends, suggesting some minor variation in source composition. Several samples from Expedition 312 also show similar deviations.

Basalts from different igneous subdivisions in Holes $1256 \mathrm{D}$ and $1256 \mathrm{C}$ all have $\mathrm{MgO}$ in the range 5-9 $\mathrm{wt} \%$, and when trace element compositions of Site 1256 basalts are compared to compilations of EPR MORB, they are on the relatively trace elementdepleted side of average EPR MORB (Figs. F38, F39). Note that Site 1256 basalts have higher $\mathrm{Zr} / \mathrm{Y}$ and lower $\mathrm{Ti} / \mathrm{Zr}$ ratios than the strongly trace elementdepleted MORB from Hole 504B (Figs. F39, F40), suggesting a more depleted mantle source or larger degrees of partial melting in the latter.

Compared with other first-order mid-ocean-ridge segments along the EPR, basalts from Site 1256 have very low $\mathrm{Zr} / \mathrm{TiO}_{2}$ and $\mathrm{Zr} / \mathrm{Y}$ ratios (Figs. F40, F41). Although there is overlap among segments and large scatter in the data for each segment, $\mathrm{Zr} / \mathrm{TiO}_{2}$ and $\mathrm{Zr} /$ $\mathrm{Y}$ ratios appear to decrease with increasing spreading 
rate. It should be emphasized that Site 1256 basalts have considerably lower $\mathrm{Zr} / \mathrm{Y}$ and higher $\mathrm{Ti} / \mathrm{Zr}$ ratios at given $\mathrm{MgO} \mathrm{wt} \%$ than the present-day MORB from the EPR between $5^{\circ} \mathrm{N}$ and $10^{\circ} \mathrm{N}$, the closest data to the projected position of Site 125615 m.y. ago at $\sim 1^{\circ} \mathrm{N}$ on the EPR (Fig. F39). If mantle sources were similar during the past 15 m.y. at the EPR, the above lines of evidence suggest a higher degree of partial melting at $\sim 15 \mathrm{Ma}$ at Site 1256 associated with the higher rate of spreading. Otherwise, the data must reflect regional-scale mantle heterogeneity.

Of all the basalts from Site 1256, the lava pond is the only unit that is relatively enriched in $\mathrm{V}$ and depleted in Cr compared to EPR MORB. The lava pond includes the rocks with the highest incompatible element concentrations $\left(\mathrm{Zr}, \mathrm{TiO}_{2}, \mathrm{Y}\right.$, and $\left.\mathrm{V}\right)$ and the most depleted compatible element concentrations ( $\mathrm{Cr}$ and $\mathrm{Ni}$ ), suggesting that it is more evolved than the rest of the basalts from Hole 1256D (Fig. F39).

\section{Alteration}

One of the principal objectives of the combined missions (Leg 206 and Expedition 309/312) is to investigate the alteration processes that occur in a section of upper crust that formed at superfast spreading rates $(200-220 \mathrm{~mm} / \mathrm{y})$ to test whether these differ from those documented in crust formed at slow and intermediate spreading rates. Of particular interest during Expedition 309/312 is the opportunity to observe the transition between low-temperature alteration and high-temperature hydrothermal alteration in a continuous section of oceanic crust. To date, this transition has only been described in Hole 504B. All rocks in the ocean crust intersected by Hole $1256 \mathrm{D}$ are partially altered to secondary minerals, and the products of fluid-rock exchange are manifest by background alteration, alteration halos related to veins, isolated alteration patches, and veins and breccias (Figs. F42, F43, F44).

Two main alteration types were encountered in the section of Hole 1256D drilled during Expedition 309. From 752 to 965 mbsf, rocks that had reacted with seawater at low temperatures, similar to the range of conditions encountered in Leg 206 cores, are present. The background alteration is uniform, from $85 \%$ to $100 \%$ dark gray, because of the presence of saponite filling vesicles and replacing olivine and plagioclase, clinopyroxene phenocrysts and chalcedony and calcium carbonate filling vesicles, and miarolitic voids (Fig. F42). The predominant vein mineral phases related to low-temperature alteration in Hole 1256D include saponite, celadonite, iron oxyhydroxides, chalcedony, and minor pyrite (Figs. F43, F44). Celadonite is commonly intergrown with iron oxyhydroxides with later overgrowths of saponite.
Specific vein-related alteration types identified in Hole 1256D include black halos, brown halos, mixed halos, simple light green, dark green, and light gray halos, and discontinuous pyrite halos (Fig. F42). Black, brown, and mixed halos and dark patches are common throughout the rocks from 752 to $918 \mathrm{mbsf}$ and are related to veins filled by saponite, celadonite, and iron oxyhydroxides. These halos result from the more pervasive replacement of the host rock groundmass, as well as olivine and plagioclase phenocrysts. The formation of black halos derives from an early low-temperature seawater-basalt interaction under anoxic conditions, which initiated during cooling of the lava within 1-2 m.y. of basalt emplacement (Böhlke et al., 1981; Honnorez, 1981; Laverne, 1993; summary in Alt, 2004). Subsequent interaction of the basalts with cold oxidizing seawater produces brown halos characterized by replacement of primary phases by saponite and iron oxyhydroxides. From 918 to 964 mbsf, black, brown, and mixed halos are absent (Fig. F42) and dark gray background alteration with abundant saponite and pyrite is ubiquitous. These rocks, as well as saponite- and pyritebearing intervals cored during Leg 206 (e.g., 554-562 mbsf), result from the interaction of basalt with lowtemperature basement fluids that have chemically evolved from seawater through water-rock reactions.

The interval from 964 to 1028 mbsf is characterized by the presence of pyrite-rich alteration halos, mixed-layer chlorite-smectite, and anhydrite (Fig. F45). This alteration mineral assemblage suggests more elevated temperatures $\left(100^{\circ}-200^{\circ} \mathrm{C}\right)$ than shallower in the crust. Below 1028 mbsf, green and dark green background alteration, particularly in the coarser grained rocks, occurs as a consequence of the moderate to complete replacement (up to 100\%) of basaltic clasts and glass in the mineralized volcanic breccia to saponite/chlorite and minor talc. The first occurrences of actinolite, prehnite, titanite, and epidote are recorded at 1027, 1032, 1051, and 1095 mbsf, respectively (Fig. F45). These minerals are indicative of hydrothermal alteration under subgreenschist to greenschist facies conditions. In this part of the crust, alteration halos occur both as simple dark gray, dark green, light gray, and light green halos and composite halos in which every combination of these colors is possible. These halos comprise $10 \%-$ $100 \%$ secondary minerals with chlorite, actinolite, titanite, albite, and pyrite replacing plagioclase and clinopyroxene and filling interstitial spaces, along with minor quartz, chalcopyrite, epidote, and prehnite.

The upper sheeted dikes in Hole 1256D are slightly to completely altered by hydrothermal fluids. Most rocks display dark gray alteration in which clinopy- 
roxene is partially altered to dusty, corroded clinopyroxene and actinolite and plagioclase is partially replaced by albite and chlorite. Titanite is a common accessory. Interstitial glass is replaced by chlorite, but below 1300 mbsf actinolite is more abundant. Veins are common features of all cores and are present at a frequency of $\sim 30$ veins $/ \mathrm{m}$. Chlorite is the most common vein filling, although quartz, pyrite, chalcopyrite, actinolite, prehnite, laumontite, and calcite are also common vein fillings. Anhydrite veins are common to 1200 mbsf. Many veins have $1-10 \mathrm{~mm}$ wide halos in which the wallrock is highly altered to chlorite, albite, actinolite, titanite, quartz, pyrite, calcite, and prehnite that replace plagioclase and clinopyroxene and fill interstitial pore space. Halos commonly comprise a narrow $(1-10 \mathrm{~mm})$ dark green chlorite-rich margin adjacent to veins surrounded by a wider $(5-20 \mathrm{~mm})$ light gray halo. Crosscutting relationships indicate that groundmass replacement and vein filling by chlorite, titanite, albite, actinolite, and pyrite are relatively early, but this alteration can be overprinted by hydrothermal veins composed of quartz, chlorite, epidote, pyrite, chalcopyrite, and rare sphalerite. Late crosscutting assemblages that probably formed at lower temperatures $\left(100^{\circ}-250^{\circ} \mathrm{C}\right.$ ?) include anhydrite, prehnite, laumontite, and calcite.

Hydrothermal alteration is most spectacularly manifest by two phenomena: (1) centimeter-scale hydrothermal alteration patches and (2) mineralized dike margins. Alteration patches comprise centimeterscale zones of $100 \%$ hydrothermal minerals, most commonly quartz, prehnite, laumontite, chlorite, anhydrite, and calcite either replacing altered rock or filling pore space, surrounded by dark chloritic halos in which there is near complete replacement of groundmass phases. Secondary magnetite is a common accessory phase. Alteration patches have no clear relationship to veins and are common features throughout the dikes.

Deeper than $\sim 1320$ mbsf, actinolite becomes dominant over chlorite (Fig. F45). Clinopyroxene is partially to completely replaced by actinolite with abundant magnetite inclusions, and actinolite is the most common vein filling. Quartz-chlorite alteration patches in the upper dikes (above $\sim 1300 \mathrm{mbsf}$ ) give way to rare actinolite-rich patches, but the latter are small $(\sim 5 \mathrm{~mm})$. Brown pleochroic hornblende in veins and replacing clinopyroxene is common below $\sim 1340$ mbsf.

Many of the subvertical dike margins encountered are disrupted by complex vein networks that brecciate the chilled contacts with intense hydrothermal recrystallization of the surrounding groundmass to chlorite, actinolite, quartz, pyrite, and chalcopyrite.
Deeper in the sheeted dikes, below 1300 mbsf, sulfide mineralization at the dike margins is less abundant, but many intrusive contacts are lined with secondary magnetite.

There is a profound change in texture and secondary mineralogy in basalts deeper than 1348 mbsf, with the dikes exhibiting a distinctive granoblastic texture in which significant proportions of these rocks are thoroughly recrystallized to microcrystalline granular aggregates of secondary clinopyroxene, orthopyroxene, actinolitic hornblende, plagioclase, and subrounded blebs of magnetite and ilmenite. The granoblastic assemblage is heterogeneous, and only rarely are large areas completely recrystallized. More commonly, the granoblastic dikes have only a minor proportion of completely recrystallized $0.5-1 \mathrm{~mm}$ patches included within zones in which there is only minor replacement of the original igneous texture by clinopyroxene and orthopyroxene. Subrounded, equant secondary magnetite is commonly the most visible indicator of partial recrystallization. The granoblastic assemblage can also occur as bands and veins. The zone of most intense development of the granoblastic texture is from 1370 to $1397 \mathrm{mbsf}$, and the basalts directly overlying the gabbros are only partially to strongly recrystallized. If the relative ferocity of recrystallization is principally the result of the reheating of these rocks, as appears likely, the occurrence of the most extensively granoblastic texture $\sim 10-35 \mathrm{~m}$ above the dike/gabbro contact possibly indicates this boundary is not horizontal. The relative timing of hydrothermal alteration and recrystallization of the granoblastic dikes is difficult to discern. Secondary clinopyroxene can be host to magnetite inclusions, perhaps indicating growth from magnetite-riddled actinolite, which is a common alteration product of igneous clinopyroxene at higher levels in the dikes. Crosscutting hornblende, actinolite, and chlorite veins indicate that significant hydrothermal alteration postdates the granoblastic recrystallization.

Gabbros of the plutonic section are dark gray to dark gray-green, with a greenish hue signifying more extensive replacement of clinopyroxene by actinolitic hornblende (Fig. F46). Plagioclase, when altered, generally appears whiter than the igneous feldspar and commonly has rims replaced by secondary feldspar and actinolite + chlorite. The intensity of gabbro alteration is strongly dependent on the grain size of the rock. Gabbro with large ( 10-15 mm) ophitic clinopyroxenes intergrown with plagioclase is much less altered than the irregular coarser grained zones between. The intrusive margins at the top of the plutonic section and the boundaries with the dike screen were the loci for extensive hydrothermal al- 
teration. Leucocratic rocks (e.g., Units 1256D-82, 90b, 90c, and 90f) are more altered than the host gabbros or dikes, although this may reflect the relative abundance of such rock types near intrusive margins and the narrow ( $\sim-15 \mathrm{~mm})$ width of many leucocratic intrusions. These leucocratic rocks are commonly altered to amphibole, secondary plagioclase, chlorite, epidote, prehnite, and titanite. The host rocks around leucocratic dikes are commonly intensively altered, with $2-15 \mathrm{~mm}$ dark green amphibole and chlorite-rich halos with replacement of clinopyroxene by actinolitic hornblende and plagioclase to secondary feldspar, actinolitic hornblende, prehnite, and epidote.

The basalts in the dike screen within the plutonic section are dark gray fine-grained to cryptocrystalline basaltic dikes that are partially recrystallized to granular assemblages with smooth annealed grain boundaries. The igneous texture of the dikes is maintained by plagioclase, but clinopyroxene is partially to completely recrystallized to subrounded grains. Titanomagnetite is partially recrystallized to subrounded grains, but many grains have more angular shapes than those within the granoblastic dikes overlying the upper gabbro. The lowermost unit recovered in Hole $1256 \mathrm{D}$ is a late dike in which clinopyroxene is altered to dusty clinopyroxene-actinolite, actinolite, chlorite, and secondary plagioclase while maintaining the primary intergranular igneous texture. The absence of granoblastic texture indicates that this basalt was intruded into the lower dike screen and possibly the overlying gabbros.

The volcanic rocks from Hole 1256D are generally less altered compared to most other basement sites (e.g., Sites 417 and 418, Holes 504B and 896A). The lavas of Hole $1256 \mathrm{D}$ contain a much smaller proportion of oxidized alteration halos compared to Holes 504B and 896A, and these effects do not systematically diminish with depth (Fig. F47). Instead, the effects of alteration by oxidizing seawater occur irregularly with depth associated with steeply dipping vein networks. The amount of calcite within Hole 1256D is also very low compared to other basement penetrations.

Although pyrite is abundant in the lower lavas and upper sheeted dikes at Site 1256, intense quartz-epidote-Fe, $\mathrm{Cu}, \mathrm{Zn}$, and $\mathrm{Pb}$ sulfide stockwork-like mineralization like that in Hole 504B is not present in the transition zone. However, anhydrite, which is sparse in Hole 504B (Teagle et al., 1998), is abundant at Site 1256. At both Sites 504 and 1256, there are stepwise increases downward in alteration temperatures at the transition zone (from $\sim 100^{\circ} \mathrm{C}$ to $\sim 250^{\circ} \mathrm{C}$ ), and alteration temperatures within the sheeted dikes at both sites increase downward, from $\sim 250^{\circ} \mathrm{C}$ at the top to $\sim 400^{\circ} \mathrm{C}$ at the base of upper dikes. This change in alteration temperature occurs over $\sim 1 \mathrm{~km}$ in Hole $504 \mathrm{~B}$, however, whereas in Hole $1256 \mathrm{D}$ this occurs over only $300 \mathrm{~m}$. This is independent of the superimposed heating and recrystallization to granoblastic textures in the basal dikes of Hole 1256D, related to the gabbro intrusions that resulted in recrystallization at temperatures possibly $>800^{\circ} \mathrm{C}$.

\section{Structure}

Basalts recovered during Expedition 309/312 exhibit brittle structures and minor brittle-ductile structures. The main structural features are represented by veins, vein networks, fractures, cataclastic zones, shear veins, microfaults, and breccia (Fig. F48). Primary igneous structures include syn- to late-magmatic structures, partially linked to flow and solidification of lava. Three main types of breccia were recovered during Expedition 309 (<1255 mbsf): incipient breccia, hyaloclastite, and hydrothermal breccia. Breccias recovered during Expedition 312 (>1255 mbsf) are mainly associated with chilled dike margins. Observed petrofabrics include magmatic flow indicators, local cataclastic domains related to alteration and/or intrusive processes, and recrystallization textures. Unique to gabbroic rocks are magmatic patches, boundaries between contrasting melts and xenoliths, and textural and compositional bands.

In the sheet and massive flows (752-1004.2 mbsf), structures and fracturing are heterogeneously partitioned and are most intensely developed at the top of the massive flows. Vertical sets of veins, cataclastic zones, and shear veins are present in massive units, whereas breccias (incipient breccia) are more common in sheet flows. On the whole, the vertical vein sets become more common from $~ 900$ mbsf. Most structures are related to the cooling of lava and are represented by curved, radial, Y-shaped, and irregular veins filled with secondary minerals.

The transition zone (1004.2-1060.9 mbsf) is characterized by steeply dipping chilled dike margins and the presence of cataclastic zones, breccias (mostly hyaloclastite), and vertical veins. The cataclastic massive unit in Section 309-1256D-117R-1 consists of rounded to angular clasts of dolerite and glassy spherulitic to variolitic basalt. Three to four centimeters of cataclasite separates doleritic basalt fragments from chilled fragments (Fig. F49). The cataclastic zone is characterized by a complex network of tiny veins, mostly dark green, dark brown, and light green, on the cut surface of the core. The light green veins have an aphanitic vitreous luster and disturb and cut across dark brown cataclastic saponite-bearing bands. These bands have cataclasite and proto- 
cataclasite textures and are cut by ultracataclasite and gouge. The crosscutting relationships between the different types of fault rocks are visible in a thin section (Fig. F49). Vein networks and cataclastic banding have caused incipient brecciation of the host rock, and larger fragments show only minor relative rotation. Flow-related microstructures and laminations are observed in very narrow $(0.2-0.5 \mathrm{~mm}$ wide) veins. In the thin section, fragments of plagioclase exhibit intergranular and intragranular deformation. Clasts are surrounded by a banded matrix that displays flow textures and is made up of subangular and rounded fragments of minerals and altered glass of variable grain size.

The intensity of fracturing downhole (Fig. F50) is mostly slight with the exception of the mineralized volcanic breccia (Unit 1256D-42; Sections 3091256D-122R-1 and 122R-2), a hyaloclastite with abundant sulfide minerals. This volcanic breccia consists of aphyric basalt clasts with subangular to subrounded shapes (ranging in size from $2 \mathrm{~mm}$ to 7 $\mathrm{cm})$, volcanic glass clasts, glassy shards, and subrounded to rounded altered glassy shards (Fig. F51). Basalt clasts exhibit the textural features of sheet flows, such as spherulitic to variolitic textures (see Fig. F51) and lava flow-related folding. Clasts are embedded in a scarce fine-grained clay matrix cemented by sulfides, carbonate, and silica. In interval 309-1256D-122R-1, 52-125 cm, the mineralized volcanic breccia grades from an almost pure hyaloclastite with rare sulfides to mineralized hyaloclastite. There is a concomitant increase in basalt clasts and matrix volume with respect to glassy clasts (Fig. F52).

Numerous chilled margins were recovered in cores from the transition zone and the sheeted dikes, and these contacts are increasingly common with depth. Below 1004 mbsf, where such contacts are subvertical, they are interpreted as dike contacts, and these become very common in the sheeted dikes. Chilled margins range from lobate and interfingered to sharp. Chilled margins also contain flow banding, stretched spherulites, and injections of basalt. Many of these chilled margins are associated with, or highly disrupted by, diffuse veining and brecciation (Fig. F53). Veins and breccia domains both cut and are cut by chilled margins, and alteration of dikes is enhanced at chilled margins. Multiple dikes and banded dikes also occur. The sheeted dikes are also characterized by the first notable occurrence of systematic conjugate veins. From 1090.7 mbsf (Unit $1256 \mathrm{D}-45)$ to $1255 \mathrm{mbsf}$, all the structural features, except shear veins, are common and more abundant. Shear veins are present only in the uppermost portion of the massive basalt (Unit 1256D-44). Veins and vein networks contain indications for oblique vein opening. Only in sparse and localized shear veins is there evidence for significant noncoaxial strain. Veins are the most common brittle structure in the cores, but fractures are widespread as well. Most of the gently dipping fractures are drilling induced and may have nucleated on preexisting cooling joints and other planes of weakness, thereby hindering recovery.

Gabbroic rocks contain fabrics and structures related to melt transport. Unique to gabbroic rocks are magmatic patches, boundaries between contrasting (now gabbroic) melts and xenoliths, and textural and compositional bands. Leucocratic intrusions form bands and patches with local evidence of high-temperature shear.

Some brittle structures in the gabbros formed at high temperatures, including domains of intense microfracture of plagioclase that are largely annealed by secondary plagioclase. Alteration of the gabbros and dikes is pervasive but is enhanced in areas of veining and at intrusive contacts.

The true dip of the chilled margins measured during Expedition 309 ranges from $50^{\circ}$ to $90^{\circ}$ with a mode at $\sim 70^{\circ}-75^{\circ}$ (Fig. F54). Preliminary interpretation of FMS and UBI images during Expedition 309 indicates that these features dip steeply to the northeast. The population of structures measured during Expedition 312 has systematic changes in orientation downhole. With the exception of fractures, all structures become more steeply dipping with depth. At 1406 mbsf, gabbro intrudes the dikes with a $45^{\circ}$ dipping contact, below which structures separate into two different populations. Veins below 1406 mbsf are steeply dipping, similar to their orientation in the dikes and lavas. Leucocratic intrusions into the gabbro also have moderate to steep dips. In contrast, igneous contacts, magmatic flow fabrics, and magmatic banding in the gabbros are moderately dipping, similar to the orientation of the contact between the gabbro and the dike complex.

There is no evidence in the recovered cores for significant tilt or strain during accretion and seafloor spreading of the Site 1256 crust.

\section{Paleomagnetism}

The primary goal of paleomagnetic studies is to assess the roles of different rock types that make up the upper oceanic crust in generating marine magnetic anomalies. Magnetic remanence data were collected before and after progressive alternating-field or thermal demagnetization. Most samples have a pronounced drilling overprint, which is characterized by a steep downward direction and a radial-horizon- 
tal component that points toward the center of the core.

Because of the strong drilling overprint and uncertainty about how completely the overprint has been removed by demagnetization, we cannot yet make strong statements based on the paleomagnetic results from Expedition 309. Rocks from the lower parts of Expedition 309 recovery have higher coercivities and a pronounced increase in the apparent quality of data that occurs over the interval 9701030 mbsf. Because of the equatorial paleolatitude of the site, polarity remains ambiguous until absolute declinations can be obtained based on orienting pieces relative to the downhole logging images of the borehole wall. The component of the drilling overprint that may remain would affect inclination more than declination, so for samples for which data analysis suggests that much of the drilling overprint has been removed (e.g., Fig. F55), generally from $>1000$ mbsf, declination values will be reliable enough to determine polarity in oriented pieces. If the number of oriented pieces is small but the polarity pattern is clear from those pieces or from measurements of the downhole magnetic field, declinations from the more stable unoriented samples should be adequate for orienting pieces for structural purposes once the polarity has been determined separately.

The generally positive inclinations for Expedition 309 samples are not what is expected for the low paleolatitude. The most obvious possibility is that a significant portion of the drilling overprint remains on nearly all of the samples. A potential alternative is that there is a pervasive present-field overprint. Another alternative, tectonic tilting, cannot be entirely discounted. However, any tilting must predate deposition of the ponded lava flows at the top of the section, and the nearly north-south original strike of the ridge axis does not provide a favorable orientation for changing inclination as a response to slip on ridge-parallel faults.

Plots of the magnetic intensity against depth show a recurrent concave pattern (Fig. F56), which shows reasonable agreement with the cryptocrystalline boundaries of igneous units and subunits. Higher intensities are related to upper and lower boundaries of "cooling units," whereas lower intensity peaks occur within units. Although further shore-based analyses are required, these trends probably result from changes in the size and distribution of primary minerals (e.g., Petersen et al., 1979), in particular titanomagnetite. About $70 \%$ of the igneous units and subunits drilled during Expedition 309 show repeated concave patterns (Fig. F56), suggesting the presence of multiple cooling units (with the observed mag- netic intensity pattern) within each lithologic unit. Our calculations suggest that the average thickness of these cooling units is $\sim 1.0 \pm 0.5 \mathrm{~m}$ (Fig. F56).

Paleomagnetic measurements on Expedition 312 samples were performed on discrete samples of the working half and intact pieces of the archive half. Demagnetization was largely performed by alternating field, and eight samples were thermally demagnetized. Most samples have a pronounced drilling overprint, which is characterized by a steep downward direction and a radial-horizontal component that points toward the center of the core.

Natural remanent magnetization (NRM) directions of discrete cubes are consistently steep (inclination at least $45^{\circ}$ and usually $>60^{\circ}$ ) and generally have southerly declinations, as expected if the NRM is dominated by drilling overprint. Most samples tend steadily toward shallower inclinations during progressive alternating-field demagnetization (Figs. F57, F58), although few reach a stable direction reproduced on several successive demagnetization steps. Directional scatter at high demagnetization fields is fairly minor. Thermal demagnetization results show a gradual drop in intensity with temperature, with the final $5 \%-10 \%$ removed at $570^{\circ}$ or $580^{\circ} \mathrm{C}$ temperature steps, indicating nearly pure magnetite as the primary carrier.

Archive-half pieces generally trend toward shallow directions, but the maximum alternating field was $40 \mathrm{mT}$, so less of the overprint is removed. However, because the radially inward component of the drilling overprint adds differently to the predrilling magnetization for the two halves of the core, archive-half measurements are useful for evaluating how much of the overprint is removed and in conjunction with working half samples in order to get cleaner predrilling directions. For about half of the working-half samples, we were able to estimate a preoverprint direction from the intersection of well-constrained great circle trend fit separately to working half and archive half demagnetization trends. This estimate always has shallower inclination than the estimate from the working half alone and in a few cases reaches negative values (Fig. F59).

On Figure F60, we plot the downcore variations of the best estimate of declination and inclination for Expedition 309/312 samples. Squares represent directions for working-half samples. Shallow inclination is expected at the equatorial paleolatitude, but nearly half of our estimates remain steeper than $20^{\circ}$ and none show negative inclination, indicating a remaining bias toward drilling overprinted directions. On Figure F61, NRM, ratio of magnetization after $20 \mathrm{mT}$ versus NRM, and susceptibility are represented. 
Measured NRM intensities are probably several times higher than the predrilling values. Demagnetized inclinations approach the expected nearly horizontal values, but trends continuing to shallow at the last demagnetization suggest that overprint remains. Because of the steep orientation of the overprint, declinations are less sensitive to incomplete removal of overprint and in most cases should be adequate for approximate strike of structural features. For pieces that can be oriented by core-log integration, the declinations should also be reliable enough to determine magnetic polarity.

Downhole variations in magnetic patterns for Expedition 312 samples are minor, with demagnetization behavior of dikes indistinguishable from that of gabbros (Figs. F57, F58). NRM intensity is widely scattered in both dikes and gabbros and the distributions overlap, but intensities in the dikes are higher. When viewing the results for all of Hole 1256D (see Wilson, Teagle, Acton, et al., 2003), the striking variation is between the zones of low-temperature alteration shallower than 1000 mbsf and high-temperature alteration deeper. The shallow section is highly variable, with a majority of samples severely to completely overprinted but a small fraction showing minor overprint that appears completely removed by demagnetization. In contrast, the lower section is consistently moderately overprinted but appears to have a small fraction of the overprint remaining after maximum demagnetization. The difference probably arises from variations in grain size and oxidation of primary titanomagnetites in the shallow section, contrasted with nearly pure magnetite that is either secondary or altered to exsolve a Ti-bearing phase such as ilmenite in the hydrothermally altered section.

Integration of sample measurements with measurements of the magnetic field in the borehole should allow progress in characterizing the crustal magnetization. The amplitude of the marine magnetic anomalies in the area of the site has been satisfactorily modeled by Wilson (1996) with a layer $500 \mathrm{~m}$ thick magnetized at $10 \mathrm{~A} / \mathrm{m}$. A layer $1250 \mathrm{~m}$ thick with a magnetization of $4 \mathrm{~A} / \mathrm{m}$ would, of course, produce an equivalent anomaly. An average predrilling magnetization of $2-5 \mathrm{~A} / \mathrm{m}$ is within the plausible range for the dikes and gabbros recovered at Site 1256 , so they remain candidates for a significant fraction of the source of marine magnetic anomalies.

\section{Physical properties}

Downhole changes in physical properties reflect changes in lithology and alteration throughout the Expedition 309/312 sections. $P$-wave velocities of Expedition 309 basalts (752-1255 mbsf) range from 4.8 to $6.1 \mathrm{~km} / \mathrm{s}$ (average $=5.5 \pm 0.3 \mathrm{~km} / \mathrm{s}$ ) (Fig. F62). This average value is similar to those estimated at a regional scale based on seismic refraction data and is consistent with shipboard values from Leg 206. From 752 to $1106 \mathrm{mbsf}$, average $V_{\mathrm{p}}$ increases $\sim 0.05 \mathrm{~km} / \mathrm{s}$ for each $50 \mathrm{~m}$ down Hole $1256 \mathrm{D}$ to nearly $6.0 \mathrm{~km} / \mathrm{s}$ at $1130.6 \mathrm{mbsf}$. $V_{\mathrm{p}}$ is slightly higher below $1060 \mathrm{mbsf}$ $(5.8 \pm 0.1 \mathrm{~km} / \mathrm{s})$ than above $(5.4 \pm 0.3 \mathrm{~km} / \mathrm{s})$, but everywhere it may be reduced locally by alteration and fracturing.

Very little net change occurs in compressional velocity over the $\sim 250 \mathrm{~m}$ cored during Expedition 312 (1255-1507 mbsf) (Fig. F62). This observation masks considerable variation occurring in three asymmetric cycles. Each cycle is composed of an increase at gradients of $\sim 1 \mathrm{~km} / \mathrm{s}$ in $50 \mathrm{~m}$ and terminates with an abrupt decrease of up to $0.5 \mathrm{~km} / \mathrm{s}$ in $<7 \mathrm{~m}$. The three sharp boundaries occur at the top of intrusive units. The shallowest boundary coincides with the top of Unit 1256D-76 near 1325 mbsf, where the velocity drops by $\sim 0.4 \mathrm{~km} / \mathrm{s}$. The deeper two boundaries coincide with contacts between dikes and gabbros. One occurs near 1407 mbsf at the base of the granoblastic dikes (contact between Units 1256D-80 and 81), where the velocity drops $\sim 0.5 \mathrm{~km} / \mathrm{s}$. The other boundary is a drop of $0.3 \mathrm{~km} / \mathrm{s}$ at the top of Gabbro 2 (Unit 1256D-91). Velocities in the upper sections of the two gabbro units vary considerably, reflecting changes in porosity and density (Fig. F62). Velocity is highest in highly metamorphosed granoblastic basalt and lowest and most variable in intrusive gabbros. Thus, intrusive cycles appear to control vertical changes in velocity.

The average grain density of Expedition 309 basalts is $2.94 \pm 0.04 \mathrm{~g} / \mathrm{cm}^{3}$, and the average bulk density is $2.86 \pm 0.07 \mathrm{~g} / \mathrm{cm}^{3}$, similar to basalts recovered during Leg $206\left(2.92 \pm 0.07\right.$ and $2.82 \pm 0.10 \mathrm{~g} / \mathrm{cm}^{3}$, respectively) (Fig. F62). Densities of discrete samples do not show a strong downhole increase with depth, even considering differences in rock type. Massive and sheet flow units have the same density within error $\left(2.88 \pm 0.04\right.$ and $\left.2.86 \pm 0.07 \mathrm{~g} / \mathrm{cm}^{3}\right)$. Porosity values range from $2 \%$ to $14 \%$ (average $=4 \%$ ). There is a decrease in porosity from the massive units above 1060 mbsf to those below this level: $4 \% \pm 1 \%$ to $2 \% \pm 1 \%$, respectively (Fig. F62).

Following depth gradients that begin near 1060 mbsf, bulk density increases with depth and porosity decreases in the sheeted dikes (Fig. F63). Across the lithologic contact at 1407 mbsf, density drops from $3.04 \mathrm{~g} / \mathrm{cm}^{3}$ in the lower granoblastic dikes to 2.88 $2.90 \mathrm{~g} / \mathrm{cm}^{3}$ in the uppermost gabbros. Porosity increases from $0.1-1 \%$ to $1-8 \%$ across the boundary. Both bulk and grain densities vary more in the gabbro than in the lower dikes, consistent with the ob- 
served variability in petrology and alteration. For all Expedition 312 samples, average bulk density is 2.97 $\pm 0.09 \mathrm{~g} / \mathrm{cm}^{3}$, average grain density is $2.99 \pm 0.08 \mathrm{~g} /$ $\mathrm{cm}^{3}$, and average porosity is $1.2 \% \pm 1.4 \%$.

Thermal conductivity measurements yielded values of $1.7-3.1 \mathrm{~W} /(\mathrm{m} \cdot \mathrm{K})$ (average $=2.0 \pm 0.3 \mathrm{~W} /[\mathrm{m} \cdot \mathrm{K}]$ ) over the depth range of $752-1255 \mathrm{mbsf}$ (Fig. F62). Average thermal conductivity from the top of the sheet and massive flows (533 mbsf) to $1060 \mathrm{mbsf}$ is $1.8 \pm 0.2 \mathrm{~W} /(\mathrm{m} \cdot \mathrm{K})$. There is a significant increase in thermal conductivity starting in the transition zone and a distinct stepwise increase to $2.1 \pm 0.1 \mathrm{~W} /(\mathrm{m} \cdot \mathrm{K})$ at $1060 \mathrm{mbsf}$, at the top of the sheeted intrusives (Fig. F62). Of the major rock types recovered during Expedition 309 and Leg 206, massive basalts and dikes of the sheeted dikes have significantly higher average thermal conductivities than massive flows, sheet flows, pillows, and hyaloclastites (Fig. F62). The mineralized volcanic breccia has the highest thermal conductivity of all rocks measured at Site 1256: $2-3.1 \mathrm{~W} /(\mathrm{m} \cdot \mathrm{K})$. Thermal conductivity increases by $\sim 15 \%$ through the sheeted dikes from $\sim 2.0$ $\mathrm{W} /(\mathrm{m} \cdot \mathrm{K})$ at $1060 \mathrm{mbsf}$ to $2.3 \mathrm{~W} /(\mathrm{m} \cdot \mathrm{K})$ (Fig. F62). In the upper gabbros, the median value of thermal conductivity drops to $\sim 2.2 \mathrm{~W} /(\mathrm{m} \cdot \mathrm{K})$ and variability increases. Thermal conductivity again increases in the gabbro and dike screen, reaching values of 2.5-2.7 $\mathrm{W} /(\mathrm{m} \cdot \mathrm{K})$ at the base of the hole.

Whole-round cores were run through the multisensor track (MST) prior to splitting. Rather than considering all MST data, during Expedition 309 only measurements from the middle of pieces $>8 \mathrm{~cm}$ were used for analysis. Magnetic susceptibility in Expedition 309 rocks ranged from $\sim 0$ to $10,000 \times 10^{-5}$ SI, with the highest values corresponding to massive lava flows, massive basalts, and dikes. In the transition zone and into the sheeted dikes (1004.2-1255.1 mbsf), variability in magnetic susceptibility does not correspond to rock type and appears to be more influenced by intensity and style of alteration.

Magnetic susceptibility varies downhole with a wavelength of 100-140 m. Because magnetite appears in thin sections as a secondary product in Expedition 312 rocks, it is possible that these cycles represent variations in the nature or degree of alteration. In Expedition 312 dikes, spikes in magnetic susceptibility reach 14,000 SI units over depth intervals of $2-4 \mathrm{~m}$. Magnetic susceptibility is generally low $(\sim 2,000$ SI units) in the gabbro units with the exception of very high spikes, reaching 20,000 SI units in the uppermost 1-5 m. Large magnetite crystals are likely the source of the high magnetic susceptibility.

After corrections, gamma ray attenuation (GRA) bulk density steadily increases with depth independent of changes in lithology and alteration from $2.7 \mathrm{~g} / \mathrm{cm}^{3}$ in the Upper Dikes to $3.0-3.2 \mathrm{~g} / \mathrm{cm}^{3}$ at the base of the hole. In most cores examined during Expedition 312 , natural gamma ray counts are $0-4$ cps, but higher values (5-11 cps) were measured in eight samples in the upper dikes and gabbro units.

\section{Downhole measurements}

Following the completion of drilling during Expedition 309, a wiper trip was run over the complete basement interval and the hole was prepared for wireline logging operations. In all, five tool strings were used in the following order: the triple combo, the FMS-sonic, the UBI, the WST, and a second run of the FMS-sonic. All deployments were successful except the WST, which suffered from wireline difficulties caused by running this light tool into the open hole. The vertical deviation measured at 1200 mbsf reaches $4.3^{\circ}$, and the hole azimuth varies between $250^{\circ}$ and $290^{\circ}$. Caliper readings from both the triple combo and FMS-sonic tool strings show generally good borehole conditions (Fig. F64). The average hole diameter measurements from the FMS-sonic calipers are 11.25 inches for $\mathrm{C} 1$ and 10.90 inches for C2; this slight difference is the result of an elliptical borehole between 807 and 966 mbsf. Wide sections (>13 inches) are particularly common in this interval, as well as between 1048 and 1060 mbsf. Comparison of the caliper data from the pre- and postdrilling operations of the upper $500 \mathrm{~m}$ shows that the borehole is being progressively enlarged with continued drilling.

Overall, combined results of standard geophysical measurements and FMS and UBI images suggest that the section drilled during Expedition 309 may be separated into subsections, continuous with the three logging intervals distinguished during Leg 206 (see Wilson, Teagle, Acton, et al., 2003):

- Logging Interval I (base of casing to $346 \mathrm{mbsf}$ ) is characterized by high resistivity (up to $100 \Omega \mathrm{m}$ ) and monotonous FMS and UBI images and corresponds to the massive ponded lava.

- Logging Interval II (346-532 mbsf) is marked by a sharp increase in natural gamma ray log values, variable geophysical properties, and distinctive electrical and acoustic images that indicate the presence of pillow lavas intercalated with sheet and massive flows and hyaloclastites.

- Logging Interval III (532-920 mbsf) was identified during Leg 206 to 752 mbsf by a decrease in the range of variation of physical properties and electrical images that agree with the petrological interpretation of this zone as a sequence of massive and sheet flows. In the section drilled during Expedition 309 , this interval has moderate resistivity val- 
ues (commonly between 10 and $100 \Omega \mathrm{m}$ ) with very high, short-wavelength frequency variability. Natural radioactivity is highly variable in this interval but is usually $>2$ gAPI. Intervals of high natural radioactivity ( $>8$ gAPI) are present at 770 774, 784-796, and 842-878 mbsf. An extremely high value (37 gAPI) of natural radioactivity is recorded at 886 mbsf. At 785-843 and 853-920 mbsf, electrical resistivity increases with depth from 8.6 to $770 \Omega \mathrm{m}$ and 9.1 to $106 \Omega \mathrm{m}$, respectively. Similar trends are recorded with the FMSsonic tool where compressional velocities increase from 4 to up to $6 \mathrm{~km} / \mathrm{s}$. Logging Interval III is characterized by alternating layers of thin flows, breccias, and massive units.

- Logging Interval IV extends from 920 to 1061 mbsf. This interval is characterized by long-wavelength, large-amplitude resistivity variations. Within this interval, low-resistivity zones are generally associated with high natural radioactivity values. The lowest resistivity values are recorded at 919-927, 1028-1032, and 1047-1054 mbsf. The interval between 919 and 927 mbsf shows perturbations in the temperature profile that may indicate a highly fractured or faulted zone where fluids are circulating. The interval 1028-1032 mbsf is associated with an increase in the natural radioactivity and can confidently be correlated with the mineralized volcanic breccia (Cores 3091256D-122R through 123R; Unit 1256D-42). Logging Interval IV coincides with volcanic breccias interbedded within sheet flows as described in cores.

- Logging Interval V extends from $1061 \mathrm{mbsf}$ to the bottom of the hole and corresponds to the sheeted intrusives. This interval is characterized by high electrical resistivities (generally $>100 \Omega \mathrm{m}$ ) as high as $2500 \Omega \mathrm{m}$ at 1161 mbsf. Furthermore, extremely low $(<2$ gAPI $)$ and constant natural radioactivity is recorded in this interval. Below $1028 \mathrm{mbsf}, P$-wave values increase and velocities higher than $6 \mathrm{~km} / \mathrm{s}$ become common. In this interval, density is generally in the range 2.8-2.9 $\mathrm{g} / \mathrm{cm}^{3}$. FMS and UBI images show the common presence of subvertical, highly conductive features that dip steeply $\left(\sim 80^{\circ}-85^{\circ}\right)$ to the northeast and are interpreted to be dike margins. These regions have abundant horizontal fractures and veins.

During Expedition 309 postdrilling logging, the temperature of Hole 1256D was recorded using the TAP tool (Fig. F65). The temperature record from the TAP tool clearly does not record the equilibrium thermal state of the crust because of $\sim 33$ days of fluid circulation during drilling, but it does provide important information on the cooling of the Site 1256 lithos- phere. The maximum temperature in the hole is $60^{\circ} \mathrm{C}$-much cooler than the equilibrium temperature of $105^{\circ} \mathrm{C}$ predicted from heat flow and temperatures measured during predrilling operation (see "Predrilling logging operations"). A temperature of $60^{\circ} \mathrm{C}$ is also significantly cooler than the equilibrium temperature measured in Hole $1256 \mathrm{D}$ at $724 \mathrm{mbsf}$ before the commencement of coring during Expedition 309. There are clear perturbations in the temperature profile, with three intervals at $\sim 691,796$, and 928 mbsf displaying negative temperature excursions that indicate a slower return toward the predicted equilibrium temperature (Fig. F65). In the same figure, the resistivity log and the FMS images (917-934 mbsf) show that these intervals have very low resistivity. The 928 mbsf perturbation corresponds to a change in rock type in the recovered cores from massive aphyric basalt to a cryptocrystalline to fine-grained sheet flow (Units 1256D-34b through 35a). The transient temperature anomaly probably indicates that this interval is a zone of high permeability that was preferentially invaded by the cold drilling fluids and is consequently recovering more slowly.

Expedition 312 downhole measurements in Hole $1256 \mathrm{D}$ were conducted after drilling and coring at Site 1256 terminated. The hole was conditioned and a wiper trip run in preparation for logging. After the bottom-hole assembly (BHA) was set at 280 mbsf the following six tool strings were deployed: the triple combo, Vertical Seismic Imager (VSI), FMS-sonic, UBI-sonic, FMS, and TAP-Dual Laterolog (DLL) tool strings.

At a depth of 1440 mbsf, the cable head tension of the first tool string decreased, indicating that the tools reached total depth, $\sim 67 \mathrm{~m}$ above the total cored depth. All logging runs were conducted from this depth and provided high-quality data with an excellent overlap of logging results from Expedition 309. Borehole conditions were good during the six logging runs, and no major washouts or obstructions were encountered. The choice of tool strings and tool combinations were adjustments to the original logging plan after the failure of the DLL and the FMS tools in the first two uphole logging operations. Caliper readings from the triple combo and FMS-sonic tool strings indicate excellent borehole conditions in the newly drilled section below 1255 mbsf, with a hole diameter typically between 10 and 11 inches. However, compared to Expedition 309 Phase 1 and 2 caliper data, it is apparent that continued drilling led to progressive enlargement in the upper borehole sections (Fig. F64). The vertical deviation measured at 1427 mbsf reached $5.4^{\circ}$, and the hole azimuth 
ranged between $254^{\circ}$ and $281^{\circ}$ but was on average $271.5^{\circ}$ for the newly drilled section in Hole $1256 \mathrm{D}$.

Overall results obtained during Expedition 312 support the division of the lithology based on core description from recovered sample material. In general, the natural occurring radioactivity was measured continuously with each logging run and used to depth-match each logging run relative to the triple combo tool string logs.

Overall total gamma radiation remains relatively constant and well below 4 gAPI in the section logged during Expedition 312 (Fig. F66). The net measured formation resistivity increased with increasing depth possibly related to changes in metamorphism (see "Alteration"). This trend is interrupted at several depth intervals. Large decreases in resistivity locally result from enlarged borehole (e.g., 1300 mbsf), but decreases in resistivity are also caused by brecciated lithologies or intrusive contacts unrelated to borehole size (e.g., at 1220, 1240, 1265, 1270, 1290, and 1320 mbsf). Below 1200 mbsf, shallow and deep resistivity measurements are 500-10,000 $\Omega \mathrm{m}$ and 1000 $-140,000 \Omega \mathrm{m}$, respectively. These high readings differ strongly from the values reported during Expedition 309 and indicate a change in lithology. Strong decoupling between the shallow and deep resistivity measurements continues to total depth. The resistivity data observed in the sheeted dike complex suggests that the lithology may be divided into four sections based on variability and magnitude of electrical resistivity. These sections can be distinguished at 1060-1155, 1155-1275, 1275-1350, and 1350-1407 mbsf (Fig. F66). Overall density and neutron porosity range $1.5-3.09 \mathrm{~g} / \mathrm{cm}^{3}$ and $2 \%-75 \%$, respectively, but most variation remains small in the newly cored section of Hole 1256D. Distinct anomalies correlate with enlarged borehole diameters related to washouts. The average densities of the sheeted dike complex and the granoblastic dikes are 2.89 and $2.99 \mathrm{~g} / \mathrm{cm}^{3}$, respectively. Density drops to an average of $2.95 \mathrm{~g} / \mathrm{cm}^{3}$ in Gabbro 1 with a minimum of $2.93 \mathrm{~g} / \mathrm{cm}^{3}$. This change in density is accompanied with a decrease in compressional velocity from 6.2 to $4.6 \mathrm{~km} / \mathrm{s}$.

A vertical seismic profile (VSP) was shot in Hole 1256D during Expedition 312 to determine interval velocities and to record seismograms for further analysis of the seismic properties of upper ocean crust. It was planned to collect data at stations spaced $22 \mathrm{~m}$ apart in the open borehole. The most serious problem was poor anchoring to the borehole wall in the upper borehole sections, indicated by harmonic ringing in the seismograms. In many cases, this could be reduced when the VSI tool was moved 1-5 $\mathrm{m}$ uphole to obtain secure clamping, but stations at $1054,934,811,587$, and $444 \mathrm{mbsf}$ had to be abandoned, leaving gaps of up to $45 \mathrm{~m}$ between stations (Table T5). Inflexibility in the stacking process and lack of control on the picking routine in the automatic picking algorithm contributed to traveltime errors. Interval velocities determined at sea during the VSPs run during Leg 206 and Expedition 312 are preliminary and likely to change when the seismograms are examined in more detail on shore. In general, the VSP interval velocities parallel trends in the sonic $\log$ and the shipboard velocity measurements on recovered rock samples (Fig. F67). Although velocity magnitude differs among the various methodologies because of different frequencies of sound and the different confining pressures, trends with depth are similar. This similarity demonstrates the fundamental dependence of velocity fluctuations in uppermost crust on the primary eruptive process and the increase in velocity with depth on the increasing density of the rocks due to progressively higher temperature alteration and metamorphism. However, there are two unusually high velocity intervals, $7.6 \mathrm{~km} / \mathrm{s}$ at $1339-1361 \mathrm{mbsf}$ and 6.5 $\mathrm{km} / \mathrm{s}$ at $880-903 \mathrm{mbsf}$, that are not matched by low velocities at neighboring stations. This likely results from traveltime errors at adjacent stations but could also be explained by a nearby high-velocity intrusive body not sampled by drilling.

Preliminary analysis of the resistivity and sonic image data from Expedition 312 indicates high-quality data were obtained over the logged borehole section. It is obvious that directly above the dike/gabbro boundary the formations are characterized by discontinuous fractures, whereas the fractures in the gabbroic section are continuous. However, other data suggest that the vertically oriented high-amplitude zones in the UBI image may be tool-related artifacts rather than characteristics of the formation. These features are not observed in FMS images. FMS and UBI imagery complement each other and are crucial in reorienting core pieces. Oriented images provide essential information on reconstructing the in situ orientation of fractures and veins. Features presented in the UBI image at 1410 and 1418 mbsf have a northeast-oriented plunge and an approximate dip between $35^{\circ}$ and $40^{\circ}$ and may represent fractures. The same features are also evident on the resistivity image, where they represent zones of high conductivity.

The TAP tool was deployed at the beginning and the end of the logging operation during Expedition 312 to gain information on the thermal rebound in the borehole after coring ceased (Fig. F65). The bottom hole temperature was recorded three times, and increases from $64.24^{\circ}$ to $67.90^{\circ} \mathrm{C}$ and $86.5^{\circ} \mathrm{C}$ were ob- 
served in time frames of $\sim 5 \mathrm{~h}$ and $68.5 \mathrm{~h}$, respectively. Perturbations are visible at 900-950 and 1350-1400 mbsf with negative deviation from the temperature profile (Fig. F65). These negative temperature anomalies indicate a slower return to equilibrium temperatures and may be due to a higher influx of seawater invasion during the drilling process.

\section{Digital imaging}

Rotary coring generally returns azimuthally unoriented samples, but cores can potentially be oriented by matching features observed in the core to features imaged by wireline logging of the borehole wall. For the purpose of obtaining orientation, all wholeround core pieces that were longer than $\sim 80 \mathrm{~mm}$ and that could be rotated smoothly through $360^{\circ}$ were imaged on the Deutsche Montan Technologie Digital Color CoreScan system during Expedition 309/312. Because of limited time between the collection of downhole logging data and the end of Expedition 309 , only a few preliminary attempts at matching core images to logging images have been made. Some of these attempts show potentially good matches between the unrolled core images and the FMS and UBI data from Hole 1256D. Figure F68 shows an example using the largest piece recovered during Expedition 309 from Section 309-1256D-85R1. Although it is hard to trace fractures as sinusoids through all four panels from the FMS pads, the spacing and dip of the fractures can be matched convincingly between the core images and the FMS images with the cutting line on the north side of the core.

During Expedition 312, a total of 165 whole-core images were scanned. The total scanned length (22.8 m) represents almost $49 \%$ of the interval cored. Although it was challenging to gain whole-core images from several cores because of low recovery, images of significant lithological features (e.g., the dike/gabbro contact at Section 312-1256D-213R-1, $52 \mathrm{~cm}$ [1406.62 mbsf]) were satisfactorily obtained.

\section{Conclusions}

Expeditions 309 and 312 were the second and third scientific ocean drilling cruises in a multiphase mission to Site 1256 to recover, for the first time, a complete section of the upper oceanic crust from extrusive lavas down through the dikes and into the uppermost gabbros. During Expedition 309, Superfast Spreading Rate Crust 2, Hole $1256 \mathrm{D}\left(6.736^{\circ} \mathrm{N}\right.$, $91.934^{\circ} \mathrm{W}$ ) was successfully deepened by $503 \mathrm{~m}$ to a total depth of $1255.1 \mathrm{mbsf}(1005.1 \mathrm{msb})$. At the end of Expedition 309, Hole 1256D had penetrated a total of $>800 \mathrm{~m}$ of extrusive lavas and entered a region dominated by intrusive rocks. Following the comple- tion of a comprehensive wireline logging program, the hole was successfully exited and left clear of equipment with only minor unconsolidated fill at the bottom of the hole.

Expedition 309 (July-August 2005) was followed closely by Expedition 312, Superfast Spreading Rate Crust 3 (November-December 2005). During Expedition 312 , Hole $1256 \mathrm{D}$ was deepened by $252.0 \mathrm{~m}$ to $1507.1 \mathrm{mbsf}$ (1257.1 msb), successfully achieving the main goal of the Superfast Spreading Crust mission, penetration through lavas and dikes into gabbros. The hole now extends through the $345.7 \mathrm{~m}$ thick sheeted dike complex and $100.5 \mathrm{~m}$ into gabbroic rocks. The latter were first encountered at 1406.6 mbsf, near the middle of the depth range predicted from geophysical observations. A complete suite of wireline logging including a VSP was carried out, and the hole remains clear and open for future drilling deeper into the plutonic foundation of the crust.

The principal achievements of Expedition 309/312 are as follows (Table T1):

- Hole $1256 \mathrm{D}$ was deepened by $753.3 \mathrm{~m}$ to a total depth of $1507.1 \mathrm{mbsf}$ or $1257.1 \mathrm{msb}$, penetrating $810.9 \mathrm{~m}$ thick extrusives, a $345.7 \mathrm{~m}$ sheeted dike complex, and $100.5 \mathrm{~m}$ into gabbroic rocks. The gabbros were encountered at $1406.6 \mathrm{mbsf}$, near the middle of the depth range predicted from geophysical observations.

- The upper oceanic crust drilled in Hole $1256 \mathrm{D}$ is subdivided into the lava pond (250-350 mbsf), sheet and massive flows (534-1004 mbsf), transition zone (1004-1061 mbsf), sheeted dikes (10611406.6 mbsf), and plutonic section (1406.6$1507.1 \mathrm{mbsf})$. The basalt lavas and dikes show evidence of variable fractionation and replenishment downhole. Trace element concentrations are within one standard deviation of the average EPR MORB, albeit on the relatively trace elementdepleted side. Gabbroic rocks are fine to coarse grained (mostly medium grained), range from gabbro to oxide gabbro and gabbronorite, and include differentiated rocks (trondjhemite and quartz-rich oxide diorite). The base of the section contains a gabbronorite of uncertain origin (intrusive gabbronorite or metamorphosed dike) and is cut by a late dike. Bulk compositions of the two gabbroic bodies fall at the primitive end of the range of compositions for the lavas and dikes but are evolved compared to primitive melts in equilibrium with olivine in the mantle. This means that cumulates must form elsewhere, within the lower crust or at the crust/mantle boundary, and the lower crust cannot form by subsidence of such high-level evolved melt lenses as penetrated in Hole 1256D. 
- Hole $1256 \mathrm{D}$ is only the second penetration of the transition from low-temperature alteration to high-temperature hydrothermal alteration in a continuous section of oceanic crust, and this occurs at 1000 mbsf. Prior to Expedition 309, this transition had only been described in Hole 504B. The lavas at Site 1256 are less altered compared to most other basement sites (e.g., Sites 417 and 418 and Holes 504B and 896A), and there is not a steady decrease in the effects of seawater alteration with depth. Instead, alteration is most commonly associated with well-developed steeply dipping vein networks. Although pyrite is abundant in the Expedition 309 cores, stockwork mineralization, such as that present in Hole 504B, has not been penetrated in the transition from extrusive to intrusive rocks or the change from lowtemperature to hydrothermal alteration. The upper dikes $(<1255 \mathrm{mbsf})$ contain greenschist facies minerals, actinolite becomes abundant below $1300 \mathrm{mbsf}$, and hornblende and secondary plagioclase are present below $\sim 1350 \mathrm{mbsf}$, reflecting a steeper thermal gradient in the dikes of Hole 1256D than in Hole 504B. Superimposed on this is recrystallization of the lowermost $50 \mathrm{~m}$ of dikes in Hole 1256D as the result of intrusion by underlying gabbros.

- Dike intrusion, brecciation, and hydrothermal alteration are intimately associated, and these features become more common downhole below $1000 \mathrm{msb}$. Dips of structures generally become steeper from lavas into the dikes. Subvertical dike margins imaged by FMS and UBI in the sheeted dikes suggest that the steeply inclined $\left(>75^{\circ}\right)$ chilled margins observed in the cores have true dips toward the northeast, consistent with the paleoridge axis orientation and slight tilting toward the ridge axis.

- Physical properties show marked changes across the transition from lavas to dikes. The porosity of massive lavas decreases from $4 \%$ to $2 \%$ across the top of the sheeted dikes, and $P$-wave velocities increase from $<5.5$ to $>6 \mathrm{~km} / \mathrm{s}$ at $1240 \mathrm{mbsf}$. Average thermal conductivity in the sheet and massive flows is $1.8 \pm 0.2 \mathrm{~W} /(\mathrm{m} \cdot \mathrm{K})$, but there is a significant increase in thermal conductivity starting in the transition zone and a distinct steplike increase to $2.1 \pm 0.1 \mathrm{~W} /(\mathrm{m} \cdot \mathrm{K})$ at the top of the sheeted dikes. Physical properties also change downward across the dike/gabbro contact, exhibiting increased porosity and decreased velocity and density in the uppermost gabbros.

- A full sequence of downhole logs, including preand postdrilling temperature profiles and multiple triple combo passes and FMS and UBI imaging runs were recorded. Wireline logs confirm that Hole $1256 \mathrm{D}$ is in very good condition. Calipers on the triple combo and FMS tool strings indicate hole diameters typically between 10 and 14 inches, with the smaller diameters in the deepest part of the hole (1300-1450 mbsf). However, comparison of the pre- and postdrilling hole caliper of the upper $500 \mathrm{~m}$ of basement does indicate local enlargement of the shallower portions of Hole $1256 \mathrm{D}$ due to drilling, with a number of intervals quite strongly eroded. Velocities from a VSP experiment run in the hole generally parallel trends in the sonic $\log$ and discrete sample measurements.

\section{Preliminary assessments}

\section{Preliminary operational assessment of Expedition 309}

The drilling objective of Expedition 309 was to deepen Hole $1256 \mathrm{D}$ as much as possible during the operating time allowed. The target depth of 1350 mbsf was based on a ROP of $1.5 \mathrm{~m} / \mathrm{h}$. This was to be accomplished while leaving the hole free of junk so that it could be reentered again during Expedition 312 . Hole $1256 \mathrm{D}$ was reentered for the first time on 16 July 2005. After an initial water sample was taken with the WSTP, logging runs with the triple combo and FMS-sonic tool strings were completed to determine the condition of the hole. During Expedition 309 , the hole was cored to a depth of $1255.1 \mathrm{mbsf}$, a total of $503.1 \mathrm{~m}$ penetration, using nine C-9 coring bits. There was an overall recovery rate of $36.3 \%$, with the recovery for the final bit run at $73.2 \%$. On two occasions while coring, drops in pump pressure were noticed by the Transocean crew and the drill string was pulled out of the hole. On both occasions, cracks were found, once in the bit sub and once in the 5 inch drill pipe. Quick action and good decisions by the crew averted junking the hole on both occasions. After coring, the hole was again logged using the triple combo, FMS-sonic, and UBI tool strings. An attempt to do a seismic study using Schlumberger's WST tool was not successful because the tool could not be lowered to the bottom of the hole. Operations ended in Hole 1256D on 25 August at $1300 \mathrm{~h}$.

\section{Preliminary operational assessment of Expedition 312}

The primary coring objective for Expedition 312 was to extend Hole 1256D as deeply as possible during the allocated operational time. The target depth of 1740 mbsf was based upon an average ROP assumption of $1.0 \mathrm{~m} / \mathrm{h}$ and an average bit life of 50 rotating 
hours. An important criterion for success was to leave the hole free of metal debris at the end of the expedition so that future missions could extend the depth of the hole.

Hole $1256 \mathrm{D}$ was deepened $252.0 \mathrm{~m}$ at an average ROP of $0.8 \mathrm{~m} / \mathrm{h}$ for all bits. Average recovery for the cored interval was $18.5 \%$, which is less than the two previous cruises to this hole (Leg $206=47.8 \%$ and Expedition $309=36.3 \%$ ). To put this into perspective, the average recovery for the last ODP cruise (Leg 148 ) to Hole 504B was $8.6 \%$ (Alt, Kinoshita, Stokking, et al., 1993).

The average bit life during the expedition was $44.3 \mathrm{~h}$. If the C-7 bit that suffered a premature demise is discounted, the average bit life for the six remaining coring bits is 48.1 rotating hours. Note that the first coring bit was used in an unsuccessful attempt to wash to the bottom of the hole and does not enter into the calculations.

The hole was deepened to a total depth of 1507.1 mbsf and was exited without hardware in the bottom of the hole. A total of 9.5 operating days were lost in hole maintenance activities: 5.2 days were expended cleaning out the hole at the beginning of the expedition and another 4.3 days were consumed with fishing and milling cones from the bottom of the hole following bit failure. The 9.5 days are exclusive of the additional time that was spent washing down to the bottom of the hole following all reentries subsequent to each coring bit trip.

The hole was successfully logged with the triple combo, VSI, FMS-sonic, and UBI tool strings. An additional logging suite composed of the TAP, DLL, and Scintillation Gamma Ray Tool (SGT) instruments obtained a temperature profile of the hole prior to departure for Balboa.

\section{Preliminary scientific assessment of Expedition 309}

The primary operational objective of Expedition 309 was to drill Hole $1256 \mathrm{D}$ as deeply and as cleanly as possible to attain the first continuous sampling of the uppermost ocean crust. Despite $>30$ y of scientific ocean drilling, this fundamental objective remains an unattained ambition. Such a section will provide hitherto unavailable knowledge about the geological, geochemical, and geophysical structure of the oceanic crust and the processes responsible for its accretion and evolution. This drilling campaign will confirm the nature of axial low-velocity zones, thought to be high-level magma chambers, as well as establish the relationships between such magma chambers and the overlying dikes and eruptive lavas. It will provide critical samples to understand the in- teractions between axial and ridge flank magmatic, hydrothermal, and tectonic processes and groundtruth regional seismic and magnetic measurements.

As the critical middle leg of this combined mission, Expedition 309 was highly successful in all respects. Hole $1256 \mathrm{D}$ was deepened to a total depth of 1255 mbsf (1005 msb) and, following a comprehensive program of wireline logging, was exited cleanly. Hole 1256D was left in good condition, clear of junk and ready for deepening during Expedition 312. At the end of Expedition 309, the bottom of Hole 1256D was in a region of sheeted intrusives (below 1061 mbsf), after sampling $\sim 754 \mathrm{~m}$ of eruptive lavas and a $\sim 57 \mathrm{~m}$ thick lithologic transition zone. Reconsideration of cores recovered during Leg 206 identified two lava subdivisions that appear to have been erupted on the flanks of the ridge axis with a $\sim 100 \mathrm{~m}$ thick massive ponded lava overlying $\sim 184 \mathrm{~m}$ of lava flows with rare inflation textures that require eruption onto a subhorizontal surface. This total thickness of $\sim 284 \mathrm{~m}$ of off-axis lavas is very close to our preferred estimate ( $300 \mathrm{~m}$; see Table T2) for the lavas that buried the axial magma chamber on the ridge flanks and agrees well with geophysical interpretations (e.g., Hooft et al., 1996; Carbotte et al., 1997a). Accounting for this thickness of off-axis lavas and 250 $\mathrm{m}$ of sediments, our best estimate of the depth where gabbros will occur, at the end of Expedition 309, was between 1275 and 1550 mbsf (Table T2). At a total depth of 1255 mbsf, Hole 1256D was nearing a depth where gabbros are predicted to occur if our precruise predictions remain valid. It was thought that gabbros are certainly within range of drilling during Expedition 312, assuming progress similar to Expedition 309. A relatively thick extrusive sequence ( $\sim 470 \mathrm{~m}$ of on-axis lavas; the sheet and massive flows) (Table T4) and thin sheeted dike complex with a predicted thickness of between 215 and 490 $\mathrm{m}$ (from Expedition 309 drilling combined with the estimated depths to gabbro) is in agreement with theoretical models of the accretion of fast spreading rate ocean crust (Phipps Morgan and Chen, 1993; Wilson, Teagle, Acton, et al., 2003).

Core recovery during Expedition 309 was 36\%, although the final bit run sampled $40 \mathrm{~m}$ of massive basalts at a recovery rate of $73 \%$. The overall recovery rate of $36 \%$ is less than that achieved in the upper portion of Hole 1256D drilled during Leg 206 (48\%), but that figure is skewed by very high rates of recovery in the ponded lava flow (93\%; 250-350 mbsf); recovery of lavas beneath this unit (39\%) was similar to that of Expedition 309. These recovery rates are far superior to those achieved in Hole 504B, with average core recovery of $\sim 30 \%$ in volcanic rocks and a miserly $14 \%$ from the dikes. Poor core recovery of 
hard, fractured formations such as MORB continues to be a major operational obstacle to scientific progress by ocean drilling. Many critical questions require high-recovery continuous cores such as can be obtained on land. Presently, the integration of incomplete core with wireline logs remains extremely difficult and time consuming.

As expected for crust formed at a fast spreading rate (>80 mm/y), sheet and massive flows are the dominant extrusive rocks drilled during both Leg 206 and Expedition 309. However, deeper in the drilled section the exact nature of the sheeted dikes may be open to debate. Subvertical chilled margins are common from 1061 mbsf (Fig. F15), and wireline acoustic and electric images indicate numerous steeply dipping fractures suggestive of dike margins in this zone. Our preferred interpretation is that the lower part of Hole 1256D (below $1061 \mathrm{~m}$ ) has entered a sheeted dike complex. However, because of only partial recovery of core inherent to upper crustal ocean drilling $(\sim 36 \%)$, there is the possibility that some of the massive basalts sampled from this zone could be subvolcanic sills crosscut by thin dikes. The absence of recovered subhorizontal chilled contacts weighs against the presence of sills, but the possibility exists that such contacts were preferentially lost because of low core recovery. Further close inspection of wireline images postcruise should validate our interpretation that these rocks are sheeted dikes.

The intimate association of brecciation, dike intrusion, hydrothermal alteration, and mineralization becomes increasingly common below $\sim 1000 \mathrm{mbsf}$ and is a new observation. In these cores, there is a clear linkage between the intrusion of magmas and the penecontemporaneous incursion of mineralizing fluids during dike injection at a magmatically robust spreading ridge, as has been suggested from recent seismic anisotropy experiments undertaken at $9^{\circ} \mathrm{N}$ on the EPR (Tong et al., 2004). Together with observations from Expedition 312, these cores will enable significant progress toward understanding the interdependency of magmatic and hydrothermal processes in crust formed at fast spreading rates.

Establishment of the contribution of different layers of the oceanic crust to marine magnetic anomalies is a primary objective of Expedition 309/312. Unfortunately, all cores recovered to date from Hole 1256D suffer from very strong magnetic overprints and measurement of true paleomagnetic vectors and intensities remains extremely difficult. A nonmagnetic BHA (bit and bit sub, for example) may reduce magnetic overprinting during drilling, and that concept should be investigated. Also essential is a functioning, gyroscopically oriented, three-component wireline magnetometer with a temperature endurance $\left(\geq 100^{\circ} \mathrm{C}\right)$ that allows it to be deployed in deep basement drill holes. Such a tool would enable the magnetic properties of the ocean crust to be measured in situ.

The Expedition 309 wireline logging program generally returned good data, although only preliminary results were available onboard ship. Drilling-induced hole enlargement due to the transit of the drill string has led to the erosion of the borehole walls in places, resulting in inferior data for tools that require eccentralization and good contact with the borehole wall (Accelerator Porosity Sonde [APS], Hostile Environment Litho-Density Sonde [HLDS], UBI, and FMS). The WST failed to enter Hole 1256D past the casing, and the VSP experiment could not be conducted. Deployment of this short, light tool should probably not have been risked in this deep basement hole, particularly when superior wireline VSP tools are available.

\section{Preliminary scientific assessment of Expedition 312}

The first major objective of Expedition 312 was to test the prediction, from the correlation of spreading rate with decreasing depth to the axial melt lens, that gabbros representing the crystallized melt lens would be encountered at 900-1300 m subbasement (msb) at Site 1256. As the final scheduled expedition of this multiexpedition mission, Expedition 312 successfully achieved this scientific objective. Despite loss of nearly one-third of the scheduled coring time to remedial hole operations (reaming, fishing, and milling), drilling during Expedition 312 penetrated $252.0 \mathrm{~m}$ to $1507.1 \mathrm{mbsf}$ (1257.1 msb), successfully achieving the main goal of the Superfast Spreading Crust mission. The hole now extends through the $345.7 \mathrm{~m}$ thick sheeted dike complex and $100.5 \mathrm{~m}$ into gabbroic rocks. The latter were first encountered at $1406.6 \mathrm{mbsf}$, near the middle of the depth range predicted from geophysical observations. This confirms the prediction from the inverse correlation of spreading rate with depth to axial melt lenses, in particular for crust generated at an ultrafast spreading rate, significantly greater than any observed on the Earth today. A complete suite of wireline logging, including a VSP, was carried out, and the hole remains clear and open for future drilling deeper into the plutonic foundation of the crust.

Two other major objectives of Expedition 312 were (1) to determine the lithology and structure of the upper oceanic crust for the superfast-spreading endmember and (2) to investigate the interactions between magmatic and alteration processes, including the relationships between extrusive volcanic rocks, feeder sheeted dikes, and underlying gabbroic rocks. 
Cores recovered from the sheeted dike complex during Expedition 312 include chilled dike margins grading to microcrystalline and fine-grained doleritic material, confirming the sheeted dike lithology. Chilled dike margins were recovered during Expedition 309, but gradations in grain size were not, leading to some question as to whether the common massive basalts were flows, sills, or dikes. Penetration through the sheeted dikes during Expedition 312 reveals the effects of a steep temperature gradient. Generally similar hydrothermal alteration is present in the dikes of Hole 1256D and Hole 504B, indicating similar hydrothermal conditions at the tops and bases of their sheeted dike complexes. However, because the dike section in Hole 1256D is only $~ 300 \mathrm{~m}$ thick, compared to the $1 \mathrm{~km}$ of dikes in Hole 504B, the thermal gradient at Site 1256 was much steeper $\left(\sim 50^{\circ} \mathrm{C} / 100 \mathrm{~m}\right.$ versus $\left.15^{\circ} \mathrm{C} / 100 \mathrm{~m}\right)$.

An important new finding in Hole 1256D is the presence of granoblastic textures resulting from contact metamorphism of the lowermost $\sim 60 \mathrm{~m}$ of dikes by intrusion of underlying gabbros. This type of metamorphism has been described locally in ophiolites but never before from the seafloor. This process must be important as mid-ocean ridges go through the waxing stage of magmatic-tectonic cycles.

An important scientific question to be addressed was the nature of the melt lens (e.g., does it have the composition of a basaltic liquid or is it a cumulate?). Gabbroic rocks in Hole 1256D are diverse and range from gabbro to oxide gabbro and gabbronorite and include differentiated rocks (trondjhemite and quartz-rich oxide diorite). Bulk compositions of the two gabbroic bodies fall at the primitive end of the range of compositions for the lavas and dikes but are evolved compared to primitive melts in equilibrium with olivine in the mantle. This means that cumulates must form elsewhere, within the lower crust or at the crust/mantle boundary, and the lower crust cannot form by subsidence of such high-level evolved melt lenses as penetrated in Hole 1256D. Although Expedition 312 penetrated gabbro bodies that would be imaged seismically as melt lenses, only the uppermost $100 \mathrm{~m}$ of plutonic rocks was cored. Drilling the underlying few hundred meters of rock would further test whether a crystallized melt lens representing the "gabbro glacier" is present or whether crystallized melt lenses similar to those already drilled exist, underlain by subvertically foliated gabbros, as observed in some ophiolites. This would provide additional and more conclusive tests to models for magma chambers and the formation of lower oceanic crust.

Coring in the dikes was extremely difficult, with generally slow ROP $(<1 \mathrm{~m} / \mathrm{h})$ and low recovery $(\sim 15 \%)$. Penetration and recovery rates were higher in the gabbro $(\sim 1.5 \mathrm{~m} / \mathrm{h}$ and $\sim 30 \%)$. Although core recovery in the dikes was low, this did not significantly affect our understanding of igneous petrology/geochemistry or alteration effects. Different dike units could be established based on changes in grain size and chemistry, and alteration effects generally vary over larger distances than individual hand specimens or individual cores. Losses of vein material or of brecciated dike margins may have occurred, however, possibly leading to these being underrepresented in the recovered cores. Study of the wireline logs and core scanning, however, should be able to provide an indication of what material was not recovered. Future drilling in dike rocks may benefit from use of coring bits constructed to penetrate harder rock formations (these are currently available as drill bits but not coring bits). Expedition 312 ran short of mud because of the extensive remedial hole cleaning operations and because it was difficult to clear cuttings from the deep hole. Thus, it is essential to have an ample supply of drilling mud for any future deep drilling expedition.

The final major objective of Expedition 312 was to correlate and calibrate remote geophysical seismic and magnetic imaging of the structure of the crust with basic geological observations. Unfortunately, all cores recovered to date from Hole 1256D suffer from very strong magnetic overprints, and measurement of true paleomagnetic vectors and intensities remains extremely difficult. Shore-based demagnetization analyses should be able to remove the drilling overprint, making it possible to address this problem. A nonmagnetic BHA (bit and bit sub, for example) may reduce magnetic overprinting during drilling. Also essential is a functioning, gyroscopically oriented, three-component wireline magnetometer with a temperature endurance $\left(\geq 100^{\circ} \mathrm{C}\right)$ that allows it to be deployed in deep basement drill holes. Such a tool would enable the magnetic properties of the ocean crust to be measured in situ.

The wireline logging programs generally returned good data, although only preliminary results were available onboard ship and for this report. Results from the VSP experiment and core measurements will provide a basis for correlation of rock properties with the geophysical structure of the upper oceanic crust. Expedition 312 results show that the transition from Layer 2 to Layer 3 at Site 1256 does not correlate with the transition from dikes to gabbro. Because the Layer 2-3 transition occurs deeper than the bottom of Hole 1256D, however, we cannot draw any conclusions about what this seismic transition corresponds to in the crust. Understanding this seismic transition at Site 1256 could be accomplished 
with further drilling ( 100-400 m). Drilling-induced hole enlargement due to the transit of the drill string has led to the erosion of the upper borehole walls in places, resulting in inferior data for tools that require eccentralization and good contact with the borehole wall (APS, HLDS, UBI, VSI, and FMS). The VSI otherwise performed well during the VSP experiment.

\section{Operations}

\section{Expedition 309}

\section{Port call}

The JOIDES Resolution arrived at Puerto Cristobal, Panama, and dropped anchor at $0752 \mathrm{~h}$ on 8 July 2005. The ship was advised that the berth at PIMPSA terminal in Balboa was not available, and the port call activities were moved to San Cristobal. The vessel was moved to Pier 7A, and Expedition 309 began with first line ashore at $1420 \mathrm{~h}$ on 8 July. Port call was concluded with last line released at $1620 \mathrm{~h}$ on 12 July.

\section{Transit to Site 1256}

The last line away from Berth 7A, Cristobal, Panama, was cast at $1620 \mathrm{~h}$ on 12 July 2005, and the vessel was under way through the Panama Canal, exiting the Miraflores Locks (iodp.tamu.edu/scienceops/ gallery/exp309/Panama_canal). The ship passed under the Bridge of the Americas on 13 July and began the transit to Site 1256 . The transit was relatively benign, with the ship rolling/pitching moderately while averaging $10.1 \mathrm{kt}$ over the $822 \mathrm{nmi}$ distance. The vessel arrived at Site 1256, and thrusters were lowered at $1030 \mathrm{~h}$ on 16 July. The vessel was placed in dynamic positioning mode by $1100 \mathrm{~h}$ (Table T6).

\section{Hole 1256D}

\section{Predrilling logging operations}

A BHA consisting of a logging bit and 10 drill collars was assembled, marking the beginning of operations for Expedition 309. The drill string was assembled to a depth of 2467 meters below rig floor (mbrf), and the vibration isolated television (VIT) camera was launched to monitor reentry. Hole $1256 \mathrm{D}$ was located, the ship was offset $50 \mathrm{~m}$ northwest, and the positioning beacon was dropped at $1930 \mathrm{~h}$ on 17 July 2005. Hole 1256D was reentered at $1945 \mathrm{~h}$ (Movie M1), and the drill string was lowered to a depth of 4370 mbrf, at which point it began taking weight, indicating $\sim 27 \mathrm{~m}$ of fill.

The drill string was raised to a depth of $\sim 4368$ mbrf, and the top drive was picked up. The WSTP was lowered into the drill string to obtain a water sample and temperature measurement at 724.6 mbsf (4369.6 mbrf). The water sample was found to be murky, and low salinity $(26 \% 0)$ indicated the filters had become clogged with silt before the sampler was completely purged of nanopure water. The WSTP temperature measurement gave a flat-line temperature of $60^{\circ} \mathrm{C}$ because of a software failure in the tool. It was decided to run the WSTP again to get a better water sample. While the WSTP was cleaned for its second run, the APCT tool was deployed to obtain accurate temperature readings above $60^{\circ} \mathrm{C}$. Temperature at $712.6 \mathrm{mbsf}$ was $64.5^{\circ} \mathrm{C}$ and at $724.6 \mathrm{mbsf}$ was $65.8^{\circ} \mathrm{C}$. The second run of the WSTP, taken at 4357.6 mbrf, returned a good water sample.

The bit was raised to 3907 mbrf, and preparations were made for logging. Hole 1256D was logged using the triple combo and the FMS-sonic tool strings to determine hole condition and gauge prior to beginning coring operations. The Schlumberger logging tools were lowered into the drill string at $0030 \mathrm{~h}$ on 18 July. The hole was logged from 724.4 mbsf to casing depth. The tools were removed from the drill string at $0530 \mathrm{~h}$ on 19 July. The logging BHA was then retrieved, and an RCB coring assembly was prepared.

\section{Basement coring in Hole 1256D}

At $2325 \mathrm{~h}$, Hole 1256D was reentered with an RCB assembly. The drill string was lowered to a depth of 4370 mbrf, and a center bit was dropped. The hole was then washed and reamed to a depth of 4395 mbrf, when the bit began taking weight. The center bit was pulled, and the first core barrel was dropped. A $50 \mathrm{bbl}$ mud sweep was circulated, and coring operations began (Table T6). The hole was cored without incident to a depth of $4466.5 \mathrm{mbrf}$ ( $821.1 \mathrm{mbsf})$. The bit accumulated a total of 51.7 rotating hours and was in relatively good condition. To minimize the risk of downhole bit failure and to ensure that the hole diameter was in gauge, it was decided that subsequent bits would be changed approximately every $50 \mathrm{~h}$ (Table T7).

The drill string was redeployed and reentered Hole $1256 \mathrm{D}$ at $1911 \mathrm{~h}$ on 22 July 2005 with a new C-9 bit. The bit was lowered to bottom, and coring was resumed at $2330 \mathrm{~h}$ that day. Core 309-1256D-86R was recovered with $3.65 \mathrm{~m}$ recovery, but all the core catcher dogs were missing and it appeared that some of the core had fallen out of the core barrel. The next core barrel was dropped, and high pump pressures were noted. The barrel was pulled, and a deplugger was deployed twice to clear any obstructions. A core barrel was dropped again, and pressures had returned to a normal range. Coring was resumed at $1045 \mathrm{~h}$ on 23 July. The bit was pulled after Core 3091256D-96R with 52.1 rotating hours. 
After the drill string was recovered, a new bit was deployed and the drill string reentered Hole 1256D at $1610 \mathrm{~h}$ on 26 July. The drill string began taking weight at 4525 mbrf. The top drive was picked up, and the hole was washed and reamed to bottom. The hole was cored without incident from 4543.2 to 4604.2 mbrf (897.8-958.8 mbsf). Penetration rates and recovery dropped through this cored interval. The bit was pulled after 52.8 rotating hours.

The drill string was recovered and a new bit deployed. The bit was lowered to a depth of $3640 \mathrm{mbrf}$, and the WSTP was deployed to obtain a bottom seafloor water sample and temperature measurement. The WSTP was then recovered, and Hole $1256 \mathrm{D}$ was reentered at $1015 \mathrm{~h}$ on 30 July. The bit was lowered to a depth of 4514 mbrf. The top drive was picked up, and the hole was reamed to bottom. Coring resumed at 4604.2 mbrf (964.8 mbsf). Coring continued without incident to a depth of $4619.8 \mathrm{mbrf}$ (Core 309-1256D-110R). After retrieving this core and dropping the next core barrel, the driller noticed a pressure drop of 200-250 psi. The core barrel was pulled and depluggers were dropped twice in attempts to clear the bit throat. Pressures were still lower than normal.

While retrieving Core 309-1256D-111R, the driller again noticed pressure drops of 200-250 psi when lifting the BHA off bottom. The pressure increased when weight was applied to the bit, indicating that there was a crack in the BHA, and the drill string was retrieved. Major damage was clear to the 8.5 inch bit sub assembly $\sim 15$ inches from the bit (Fig. F69). A straight horizontal gash had opened for $\sim 150^{\circ}$ (11 inches) of the circumference of the $3 / 4$ inch thick bit sub wall, with more ragged fracture tips propagating a further $\sim 75^{\circ}$ around the pipe from each end of the clean fracture. When in tension with the drill bit hanging from the sub, the fracture opened up to 1 $\mathrm{cm}$ and the bit was held on by only $\sim 4.25$ inches of the bit sub wall. Such a failure of the bit sub assembly had not been witnessed before in the shipboard memory of scientific ocean drilling, and the rapid diagnosis and response of the Transocean operations team certainly averted a time-consuming major equipment loss in Hole 1256D. Bit number 4 was pulled after only 17.8 rotating hours and had cored $20.4 \mathrm{~m}$.

The drill string was recovered, and a new bit was deployed. Hole $1256 \mathrm{D}$ was reentered on 1 August. The bit was lowered to a depth of 4514 mbrf. The top drive was picked up, and the hole was reamed to bottom. Coring resumed at $4624.6 \mathrm{mbrf}$ (979.2 mbsf). Mud sweeps were increased to $50 \mathrm{bbl}$ to ensure cutting removal. Bit number 5 was pulled on 4 August with 50.1 rotating hours.
Hole 1256D was reentered for the seventh time on 5 August. The bit was lowered to a depth of $4657 \mathrm{mbrf}$. The top drive was picked up, and the hole was reamed to bottom. Coring resumed at $1430 \mathrm{~h}$ on 5 August at 4696.7 mbrf (1051.3 mbsf). Bit number 6 was pulled on 8 August with 50.8 rotating hours.

The drill string was recovered, and a new bit was deployed. Hole 1256D was reentered at $0148 \mathrm{~h}$ on 9 August. The bit was lowered to a depth of $4715 \mathrm{mbrf}$ (1069.6 mbsf). The top drive was picked up, and the hole was reamed to bottom. Coring resumed at 0800 $\mathrm{h}$ on 8 August at $4754.3 \mathrm{mbrf}$ (1108.9 mbsf). While cutting Core 309-1256D-146R, the driller noticed a 100 psi pressure drop. The drill string was pulled off bottom, and a 350 psi drop in pressure was noted. Core 309-1256D-146R was recovered at $1330 \mathrm{~h}$ on 11 August after a $3.0 \mathrm{~m}$ advance and a recovery of 3.5 $\mathrm{m}$. After dropping another core barrel, the pressures remained 350 psi lower than normal. It was suspected that there was another crack in the BHA. The decision was made to pull the drill string and inspect the BHA for cracks. When the bit cleared the reentry cone, the vessel was repositioned $\sim 50 \mathrm{~m}$ from the cone.

The BHA was on deck at $2300 \mathrm{~h}$ on 11 August. All drill collars and subs were inspected for cracks. Bit number 7 was pulled after 42.5 rotating hours. With no cracks in the BHA found, a new bit was made up to the drill string and the drill string was again lowered. One stand of $51 / 2$ inch transition pipe was laid out, as well as the tapered drill collar and crossover sub, because of excessive wear at the connections.

A core barrel was dropped into the BHA while running in with bit number 8 . The drill string was filled with seawater every 25 stands, and the pressure was checked. Pump pressure increases were noted at 25 and 50 stands, but there was no further pressure increases with 75 and 100 stands deployed, indicating there might be a crack in the drill string above the BHA. The VIT camera was lowered when 100 stands were below the rotary table. A pill of high-viscosity mud was pumped as a tracer as the camera was lowered. The camera passed through very cloudy water just above the BHA, indicating that mud had exited the drill pipe somewhere and drifted down. The camera was pulled up above the BHA, and another mud pill was circulated. As the VIT camera was again lowered toward the BHA, a vigorous jet of drilling mud was observed streaming from the 5 inch pipe (Movie M2) about two stands above the 51/2 inch transition pipe. The drill string was pulled back up to the rig floor, the crack was found in the 5 inch pipe, and the bottom two stands of 5 inch drill pipe were replaced (Fig. F70). 
The drill string was again lowered below the rotary table. Hole $1256 \mathrm{D}$ was reentered for the ninth time at $0230 \mathrm{~h}$ on 13 August (Movie M3). A core barrel was dropped, and coring resumed at 0730 on $13 \mathrm{Au}$ gust. Bit number 8 was pulled on 16 August after $57.8 \mathrm{~h}$ of coring.

The drill string was recovered and a new bit deployed. Hole $1256 \mathrm{D}$ was reentered at $0304 \mathrm{~h}$ on 17 August, a core barrel was dropped, and coring resumed. The ninth and final RCB coring bit of Expedition 309 was pulled on 20 August. A mud sweep was pumped before the final core barrel was retrieved at $1100 \mathrm{~h}$ on 20 August. The bit was pulled to the casing shoe and lowered back to bottom. No fill was encountered. A mud sweep was pumped around, and the drill string was pulled out of the hole. Bit number 9 was pulled after 53.1 rotating hours.

\section{Postdrilling logging operations}

A logging BHA was made up, and the hole was reentered at $\sim 0800 \mathrm{~h}$ on 21 August. The bit was set at 3905.5 mbrf (260.1 mbsf), $\sim 9 \mathrm{~m}$ above the casing shoe, and preparations were made for logging Hole $1256 \mathrm{D}$.

The first logging run with the triple combo tool string started taking weight $\sim 29 \mathrm{~m}$ above bottom, at 4871 mbrf (1225.6 mbsf). The logging run started at this depth and continued to $4200 \mathrm{mbrf}$ (554.6 mbsf). This allowed for full coverage of the section drilled during Expedition 309 and approximately the bottom $200 \mathrm{~m}$ of the original hole from Leg 206. The FMS-sonic tool string was rigged up and lowered into the hole. The FMS was unable to pass 4868 mbrf (1222.6 mbsf). The tool logged up to $4300 \mathrm{mbrf}$ (654.6 mbsf). Attempts to close the arms and lower the tool to log the entire length of the hole failed. The FMS was pulled out of the hole, encountering $\sim 700 \mathrm{lb}$ overpull while entering the drill pipe. When the tool exited the drill pipe, the arms were in the open position. The arms were manually closed, and the tool was laid out.

The third logging run utilized the UBI. The UBI was deployed with a sinker bar to enhance deployment speed. The UBI encountered fill at 4865 mbrf (1219.6 mbsf) and logged up to 4745 mbrf. The fourth logging run was to be a VSP utilizing the three-component WST and the generator-injector air gun. The tool was lowered into the drill pipe at $0400 \mathrm{~h}$ on 23 August. The tool began taking weight at $3920 \mathrm{mbrf}$ (274.6 mbsf) and was worked down to $4020 \mathrm{mbrf}$ (374.6 mbsf) but could not be lowered any further. The tool was pulled out of the hole, taking $800 \mathrm{lb}$ of overpull to enter the drill pipe. When the tool reached the surface, several kinks were noted in the Schlumberger wireline cable. A total of $60 \mathrm{~m}$ of wire- line cable was cut, and the cable was reheaded. The back-up FMS tool was rigged up, function tested, and lowered into the hole for a log of the complete hole. The tool was unable to pass 4861 mbrf (1215.6 mbsf). The tool logged up to 3950 mbrf (304.6 mbsf). Following the completion of the FMS-sonic log, the wireline heave compensator was tested to evaluate the performance of the new drum compensator and compare it to the performance of the older LDEO wireline compensator. The tools were pulled out of the drill string and were laid out.

\section{Transit to Balboa}

The ship was secured for transit and was under way at $1300 \mathrm{~h}$ on 24 August 2005. The transit was relatively benign, with the ship rolling/pitching moderately while averaging $10.1 \mathrm{kt}$ over the $822 \mathrm{nmi}$ distance. The JOIDES Resolution arrived at Balboa, Panama, at $0000 \mathrm{~h}$ on 28 August. The ship was at anchorage by $0029 \mathrm{~h}$.

\section{Expedition 312}

\section{Port call}

Expedition 312 began when the first line was placed ashore at Odgen Docks in Victoria, British Columbia (Canada), at $1225 \mathrm{~h}$ on 28 October 2005. The routine port call was accomplished in 3.8 days. The plan to conduct remedial cementing operations at two circulation obviation observatory kit (CORK) observatories installed at Site 1301 during Expedition 301 was cancelled at the last minute because of heavy seas at the location. The 13 educators participating in the School of Rock Expedition boarded the ship on the morning of 31 October. The last line was released at $0800 \mathrm{~h}$ on 1 November, as the vessel began the 2638 nmi transit to Acapulco to pick up the Expedition 312 scientific party.

During the transit, the educators applied what they learned about scientific ocean drilling through ship tours and interaction with U.S. Implementing Organization and Transocean personnel into developing a curriculum based on their shipboard experiences. The finished product will be tested in various classrooms and delivered at upcoming teacher workshops. During the transit, the teachers answered many e-mails from their students asking questions about ocean drilling. The educators departed the vessel on 12 November at $0730 \mathrm{~h}$ and continued their workshop on shore before the pilot program concluded on the evening of 13 November.

The vessel completed the $2598 \mathrm{nmi}$ transit to Acapulco, Mexico, at an average speed of $10.9 \mathrm{kt}$. The first line was secured to Berth 2, Fiscal Wharf, at $1135 \mathrm{~h}$ on 11 November. During the $22.5 \mathrm{~h}$ port call, the 
School of Rock Expedition participants were discharged and the Expedition 312 scientific party embarked. The last line was released at $0958 \mathrm{~h}$ on 12 November from Fiscal Wharf, and the vessel began the journey to Hole 1256D. In accordance with routine, the new arrivals were given a safety briefing shortly after leaving port. A presite meeting to discuss the general strategy of the expedition was held on 14 November. The 3 day journey to Hole 1256D was without incident.

The vessel completed the $763 \mathrm{nmi}$ transit from Acapulco, Mexico, to Hole $1256 \mathrm{D}$ at an average speed of $11.1 \mathrm{kt}$ and the $3361 \mathrm{nmi}$ trek from Victoria, British Columbia, to Acapulco, Mexico, to Site 1256 was accomplished at an average speed of $10.9 \mathrm{kt}$. The first piece of coring equipment was placed in the water at $0730 \mathrm{~h}$ on 15 November, shortly after positioning on site using Global Positioning System data.

\section{Basement coring in Hole 1256D}

The bit entered the reentry cone for the first time at 2030 h on 15 November 2005 (Table T8). The drill string advanced effortlessly until it contacted resistance at 927 mbsf. This was an indication of hole trouble that required extensive washing and reaming. Coring was finally initiated at $0715 \mathrm{~h}$ on 21 November and proceeded without incident as the hole was deepened from 1255.1 to 1372.8 mbsf with generally good drilling conditions. At this depth, the fifth coring bit of the expedition failed and all three cones and most of the fourth cone were left in the hole (Fig. F71). Before coring could resume, it was necessary to clean out the metal debris from the bottom of the hole. This effort required four fishing round trips (two with a fishing magnet and two with a mill) before coring could be confidently resumed.

Hole $1256 \mathrm{D}$ was reentered with the sixth rotary bit of the expedition at $0754 \mathrm{~h}$ on 8 December, and coring resumed at $1300 \mathrm{~h}$. There were no further hardware failures or major hole problems, and rotary coring deepened the hole to a final depth of 1507.1 mbsf by $0300 \mathrm{~h}$ on 19 December. A historic event was recorded when Core 312-1256D-213R arrived on deck at $0800 \mathrm{~h}$ on 13 December 2005 containing the first in situ dike/gabbro contact ever drilled from an intact section of oceanic crust.

The hole was deepened by $252.0 \mathrm{~m}$ to a total depth of $1507.1 \mathrm{mbsf}$ and abandoned without hardware in the bottom of the hole. A total of 9.5 operating days were lost to hole maintenance activities: 5.2 days were expended cleaning out the hole at the beginning of the expedition and another 4.3 days were consumed with fishing and milling the cones from the bottom of the hole after the bit failure. These 9.5 days are exclusive of the additional time that was spent washing down to the bottom of the hole after all reentries subsequent to each coring bit trip.

The average ROP during Expedition 312 was $0.8 \mathrm{~m} / \mathrm{h}$ for all bits. The average recovery for the cored interval was $18.5 \%$, which is less than the two previous cruises to this hole (Leg 206 = 47.8\%; Expedition 309 $=36.3 \%)$. To put this into perspective, the average recovery for the last ODP cruise (Leg 148) to Hole 504B was $8.6 \%$.

\section{Postdrilling logging operations}

A logging BHA was made up and reentered Hole $1256 \mathrm{D}$ at $2318 \mathrm{~h}$ on 19 December 2005. The bit was placed in the open hole at $\sim 20 \mathrm{~m}$ below the 16 inch casing shoe at a depth of 289 mbsf. The hole was successfully logged with five different tool strings:

- Triple combo

- VSI

- UBI with the general purpose inclinometry tool (GPIT), SGT, and DSI

- FMS-sonic with the SGT

- TAP, DLL, and SGT

The triple combo tool string made two passes, from 1440 to 343 mbsf and from 1438 to 1080 mbsf. A check shot experiment using the VSI was conducted at 58 stations $\sim 22 \mathrm{~m}$ apart from a maximum depth of 1383 mbsf. The UBI tool string with the GPIT, SGT, and DSI logged from 1430 to 1099 mbsf, followed by a repeat pass covering the interval from 1433 to 1089 mbsf. The FMS was combined with the SGT and logged the hole from 1437 to 1098 mbsf and from 1436 to 1089 mbsf. A last logging suite made up of the TAP, DLL, and SGT logged the hole from 325 to 1431 mbsf. The drill string was pulled out of the hole, clearing the seafloor by $1345 \mathrm{~h}$ on 23 December. The vessel was secured for sea and left for Balboa, Panama, at $2200 \mathrm{~h}$ on 23 December. The total time at Hole $1256 \mathrm{D}$ was $926.5 \mathrm{~h}$ (38.6 days).

\section{References}

Alt, J.C., 1995. Subseafloor processes in mid-ocean ridge hydrothermal systems. In Humphris, S.E., Zierenberg, R., Mullineaux, L., and Thomson, R. (Eds.), Seafloor Hydrothermal Systems: Physical, Chemical, Biological and Geological Interactions within Hydrothermal Systems. Geophys. Monogr., 91:85-114.

Alt, J.C., 1999. Very low grade hydrothermal metamorphism of basic igneous rocks. In Frey, M., and Robinson, D. (Eds.), Very Low Grade Metamorphism: Cambridge (Blackwell), 169-201.

Alt, J.C., 2004. Alteration of the upper oceanic crust: mineralogy, chemistry, and processes. In Elderfield, H., and Davis, E. (Eds.), Hydrogeology of the Oceanic Lithosphere: New York (Cambridge Univ. Press), 456-488. 
Alt, J.C., Davidson, G.J., Teagle, D.A.H., and Karson, J.A., 2003. Isotopic composition of gypsum in the Macquarie Island ophiolite: implications for the sulfur cycle and the subsurface biosphere in oceanic crust. Geology, 31:549-552. doi:10.1130/0091-

7613(2003)031<0549:ICOGIT> 2.0.CO;2

Alt, J.C., Kinoshita, H., Stokking, L.B., et al., 1993. Proc. ODP, Init. Repts., 148: College Station, TX (Ocean Drilling Program).

Alt, J.C., Laverne, C., Vanko, D.A., Tartarotti, P., Teagle, D.A.H., Bach, W., Zuleger, E., Erzinger, J., Honnorez, J., Pezard, P.A., Becker, K., Salisbury, M.H., and Wilkens, R.H., 1996. Hydrothermal alteration of a section of upper oceanic crust in the eastern equatorial Pacific: a synthesis of results from Site 504 (DSDP Legs 69, 70, and 83, and ODP Legs 111, 137, 140, and 148.) In Alt, J.C., Kinoshita, H., Stokking, L.B., and Michael, P.J. (Eds.), Proc. ODP, Sci. Results, 148: College Station, TX (Ocean Drilling Program), 417-434.

Alt, J.C., and Teagle, D.A.H., 1999. The uptake of carbon during alteration of ocean crust. Geochim. Cosmochim. Acta, 63(10):1527-1535. doi:10.1016/S00167037(99)00123-4

Alt, J.C., and Teagle, D.A.H., 2000. Hydrothermal alteration and fluid fluxes in ophiolites and oceanic crust. In Dilek, Y., Moores, E., Elthon, D., and Nicolas, A. (Eds.), Ophiolites and Oceanic Crust: New Insights from Field Studies and the Ocean Drilling Program. Spec. Pap.-Geol. Soc. Am., 349:273-282.

Autio, L.K., and Rhodes, J.M., 1983. Costa Rica Rift Zone basalts: geochemical and experimental data from a possible example of multistage melting. In Cann, J.R., Langseth, M.G., Honnorez, J., Von Herzen, R.P., White, S.M., et al., Init. Repts. DSDP, 69: Washington (U.S. Govt. Printing Office), 729-745.

Bach, W., Peucker-Ehrenbrink, B., Hart, S.R., and Blusztajn, J.S., 2003. Geochemistry of hydrothermally altered oceanic crust: DSDP/ODP Hole 504B-implications for seawater-crust exchange budgets and $\mathrm{Sr}$-and $\mathrm{Pb}$-isotopic evolution of the mantle. Geochem., Geophys., Geosyst., 4(3). doi:10.1029/2002GC000419

Banerjee, N.R., and Muehlenbachs, K., 2003. Tuff life: bioalteration in volcaniclastic rocks from the Ontong Java Plateau. Geochem., Geophys., Geosyst., 4. doi:10.1029/ 2002GC000470

Bascom, W., 1961. A Hole in the Bottom of the Sea: New York (Doubleday).

Becker, K., Foss, G., et al., 1992. Proc. ODP, Init. Repts., 137: College Station, TX (Ocean Drilling Program).

Bickle, M.J., and Teagle, D.A.H., 1992. Strontium alteration in the Troodos ophiolite: implications for fluid fluxes and geochemical transport in mid-ocean ridge hydrothermal systems. Earth Planet. Sci. Lett., 113:219-237. doi:10.1016/0012-821X(92)90221-G

Blake, R.E., Alt, J.C., and Martini, A.M., 2001. Oxygen isotope ratios of $\mathrm{PO}_{4}$ : an inorganic indicator of enzymatic activity and P metabolism and a new biomarker in the search for life. Proc. Natl. Acad. Sci. U. S. A., 98(5):21482153. doi:10.1073/pnas.051515898
Böhlke, J.K., Honnorez, J., Honnorez-Guerstein, B.-M., Muehlenbachs, K., and Petersen, N., 1981. Heterogeneous alteration of the upper oceanic crust: correlation of rock chemistry, magnetic properties, and O-isotope ratios with alteration patterns in basalts from Site 396B, DSDP. J. Geophys. Res., 86:7935-7950.

Cande, S.C., and Kent, D.V., 1995. Revised calibration of the geomagnetic polarity timescale for the Late Cretaceous and Cenozoic. J. Geophys. Res., 100:6093-6095. doi:10.1029/94JB03098

Cannat, M., Karson, J.A., Miller, D.J., et al., 1995. Proc. ODP, Init. Repts., 153: College Station, TX (Ocean Drilling Program).

Carbotte, S., Mutter, C., Mutter, J., and Ponce-Correa, G., 1997a. Influence of magma supply and spreading rate on crustal magma bodies and emplacement of the extrusive layer: insights from the East Pacific Rise at lat $16^{\circ}$ N. Geology, 26:455-458. doi:10.1130/00917613(1998)026 <0455:IOMSAS >2.3.CO;2

Carbotte, S.M., Mutter, J.C., and Xu, L., 1997b. Contribution of volcanism and tectonism to axial and flank morphology of the southern East Pacific Rise, $17^{\circ} 10^{\prime}-$ $17^{\circ} 40^{\prime}$ S, from a study of Layer $2 \mathrm{~A}$ geometry. J. Geophys. Res., 102(B5):10165-10184. doi:10.1029/96JB03910

Coogan, L.A., Jenkin, G.R.T., and Wilson, R.N., 2002a. Constraining the cooling rate of the lower oceanic crust: a new approach applied to the Oman ophiolite. Earth Planet. Sci. Lett., 199(1-2):127-146. doi:10.1016/ S0012-821X(02)00554-X

Coogan, L.A., Thompson, G., and McLeod, C.J., 2002b. A textural and geochemical investigation of high level gabbros from the Oman ophiolite: implications for the role of the axial magma chamber at fast-spreading ridges. Lithos, 63:67-82. doi:10.1016/S00244937(02)00114-7

COSOD II, 1987. Rep. 2nd Conf. Scientific Ocean Drilling: Washington/Strasbourg (JOIDES/European Sci. Found.).

Detrick, R.S., Collins, J.A., Stephen, R.A., and Swift, S.A., 1994. In situ evidence for the nature of the seismic Layer $2 / 3$ boundary in oceanic crust. Nature (London, $U$. K.), 370:288-290. doi:10.1038/370288a0

Detrick, R.S., Toomey, D.R., and Collins, J.A., 1998. Threedimensional upper crustal heterogeneity and anisotropy around Hole 504B from seismic topography. J. Geophys. Res., 103(B12):30485-30504. doi:10.1029/ 98JB02409

Dick, H.J.B., and Mével, C., 1996. The Oceanic Lithosphere and Scientific Drilling into the 21st Century: Woods Hole, MA (ODP-InterRidge-IAVCEI).

Dick, H.J.B., Natland, J.H., Miller, D.J., et al., 1999. Proc. ODP, Init. Repts., 176: College Station, TX (Ocean Drilling Program).

Edmond, J.M., Measures, C., Magnum, B., Grant, B., Sclater, F.R., Collier, R., Hudson, A., Gordon, L.I., and Corliss, J.B., 1979. On the formation of metal-rich deposits at ridge crests. Earth. Planet. Sci. Lett., 46:19-30. doi:10.1016/0012-821X(79)90062-1

Elderfield, H., and Schultz, A., 1996. Mid-ocean ridge hydrothermal fluxes and the chemical composition of 
the ocean. Annu. Rev. Earth Planet. Sci., 24(1):191-224. doi:10.1146/annurev.earth.24.1.191

Elderfield, H., Wheat, C.G., Mottl, M.J., Monnin, C., and Spiro, B., 1999. Fluid and geochemical transport through oceanic crust: a transect across the eastern flank of the Juan de Fuca Ridge. Earth Planet. Sci. Lett., 172(1-2):151-165. doi:10.1016/S0012-

821X(99)00191-0

Expedition 304 Scientists, 2005. Oceanic core complex formation, Atlantis Massif-oceanic core complex formation, Atlantis Massif, Mid-Atlantic Ridge: drilling into the footwall and hanging wall of a tectonic exposure of deep, young oceanic lithosphere to study deformation, alteration, and melt generation. IODP Prel. Rept., 304. doi:10.2204/iodp.pr.304.2005

Expedition 305 Scientists, 2005. Oceanic core complex formation, Atlantis Massif-oceanic core complex formation, Atlantis Massif, Mid-Atlantic Ridge: drilling into the footwall and hanging wall of a tectonic exposure of deep, young oceanic lithosphere to study deformation, alteration, and melt generation. IODP Prel. Rept., 305. doi:10.2204/iodp.pr.305.2005

Farrell, J.W., Raffi, I., Janecek, T.C., Murray, D.W., Levitan, M., Dadey, K.A., Emeis, K.-C., Lyle, M., Flores, J.-A., and Hovan, S., 1995. Late Neogene sedimentation patterns in the eastern equatorial Pacific Ocean. In Pisias, N.G., Mayer, L.A., Janecek, T.R., Palmer-Julson, A., and van Andel, T.H. (Eds.), Proc. ODP, Sci. Results, 138: College Station, TX (Ocean Drilling Program), 717-756.

Furnes, H., and Staudigel, H., 1999. Biological mediation in ocean crust alteration: how deep is the deep biosphere? Earth Planet. Sci. Lett., 166:97-103. doi:10.1016/S0012-821X(99)00005-9

Gillis, K., Mével, C., Allan, J., et al., 1993. Proc. ODP, Init. Repts., 147: College Station, TX (Ocean Drilling Program).

Gillis, K.M., Coogan, L.A., and Pedersen, R., 2005. Strontium isotope constraints on fluid flow in the upper oceanic crust at the East Pacific Rise. Earth Planet. Sci. Lett., 232(1-2):83-94. doi:10.1016/j.epsl.2005.01.008

Gillis, K.M., Muehlenbachs, K., Stewart, M., Gleeson, T., and Karson, J., 2001. Fluid flow patterns in fast spreading East Pacific Rise crust exposed at Hess Deep. J. Geophys. Res., 106:26311-26329. doi:10.1029/ 2000JB000038

Gillis, K.M., and Roberts, M.D., 1999. Cracking at the magma-hydrothermal transition: evidence from the Troodos ophiolite, Cyprus. Earth Planet. Sci. Lett., 169:227-244. doi:10.1016/S0012-821X(99)00087-4

Hallenborg, E., Harding, A.J., Kent, G.M., and Wilson, D.S., 2003. Seismic structure of 15 Ma oceanic crust formed at an ultrafast spreading East Pacific Rise: evidence for kilometer-scale fracturing from dipping reflectors. $J$. Geophys. Res., 108(B11):2532. doi:10.1029/ 2003JB002400

Honnorez, J., 1981. The aging of the oceanic crust at low temperature. In Emiliani, C. (Ed.), The Sea (Vol. 7): The Oceanic Lithosphere: New York (Wiley), 525-587.

Hooft, E.E.E., Schouten, H., and Detrick, R.S., 1996. Constraining crustal emplacement processes from variation in seismic layer $2 \mathrm{~A}$ thickness at the East pacific Rise. Earth Planet. Sci. Lett., 142(3-4):289-309. doi:10.1016/ 0012-821X(96)00101-X

Hosford, A., Tivey, M., Matsumoto, T., Dick, H., Schouten, H., and Kinoshita, H., 2003. Crustal magnetization and accretion at the Southwest Indian Ridge near the Atlantis II Fracture Zone, 0-25 Ma. J. Geophys. Res., 108(B3). doi:10.1029/2001JB000604

International Working Group, 2001. Earth, Oceans, and Life: Scientific Investigation of the Earth System Using Multiple Drilling Platforms and New Technologies-Integrated Ocean Drilling Program Initial Science Plan, 2003-2013. Washington, DC (International Working Group Support Office).

Karson, J.A., 2002. Geologic structure of the uppermost oceanic crust created at fast- to intermediate-rate spreading centers. Annu. Rev. Earth Planet. Sci., 30:347384. doi:10.1146/annurev.earth.30.091201.141132

Karson, J.A., Klein, E.M., Hurst, S.D., Lee, C.E., Rivizzigno, P.A., Curewitz, D., Morris, A.R., and Hess Deep 1999 Scientific Party, 2002. Structure of uppermost fast-spread oceanic crust exposed at the Hess Deep Rift: Implications for subaxial processes at the East Pacific Rise, Geochem., Geophys., Geosyst., 3(1):1002. doi:10.1029/ 2001GC000155

Kelemen, P.B., Kikawa, E., Miller, D.J., et al., 2004. Proc. ODP, Init. Repts., 209: College Station, TX (Ocean Drilling Program). doi:10.2973/odp.proc.ir.209.2004

Kelemen, P.B., Koga, K., and Shimizu, N., 1997. Geochemistry of gabbro sills in the crust-mantle transition zone of the Oman ophiolite: implications for the origin of the oceanic lower crust. Earth Planet Sci. Lett., 146:475488. doi:10.1016/S0012-821X(96)00235-X

Kempton, P.D., Autio, L.K., Rhodes, J.M., Holdaway, M.J., Dungan, M.A., and Johnson, P., 1985. Petrology of basalts from Hole 504B, Deep Sea Drilling Project, Leg 83. In Anderson, R.N., Honnorez, J., Becker, K., et al., Init. Repts. DSDP, 83: Washington (U.S. Govt. Printing Office), 129-164.

Laverne, C., 1993. Occurrence of siderite and ankerite in young basalts from the Galapagos Spreading Center (DSDP Holes 506G and 507B). Chem. Geol., 106(12):27-46. doi:10.1016/0009-2541(93)90164-E

Laverne, C., Agrinier, P., Hermitte, D., and Bohn, M., 2001. Chemical fluxes during hydrothermal alteration of a 1200-m long section of dikes in the oceanic crust, DSDP/ODP Hole 504B. Chem. Geol., 181:73-98. doi:10.1016/S0009-2541(01)00277-7

Macdonald, K.C., Haymon, R., and Shor, A., 1989. A 220 $\mathrm{km}^{2}$ recently erupted lava field on the East Pacific Rise near lat $8^{\circ}$ S. Geology, 17:212-216. doi:10.1130/00917613(1989)017 <0212:AKRELF>2.3.CO;2

MacLeod, C.J., and Yaouancq, G., 2000. A fossil melt lens in the Oman ophiolite: implications for magma chamber processes at fast spreading ridges. Earth Planet. Sci. Lett., 176:357-373. doi:10.1016/S0012821X(00)00020-0

Manning, C.E., MacLeod, C.J., and Weston, P.E., 2000. Lower-crustal cracking front at fast spreading ridges: 
evidence from the East Pacific Rise and the Oman ophiolite. In Dilek, Y., Moores, E.M., Elthon, D., and Nicolas, A. (Eds.), Ophiolites and Oceanic Crust: New Insights from Field Studies and the Ocean Drilling Program. Spec. Pap.Geol. Soc. Am., 349:261-272.

Menard, H.W., 1964. Marine Geology of the Pacific: New York (McGraw-Hill).

Murray, R.W., Schrag, D.P., and Wheat, C.G., 2002. Opportunities in Geochemistry for Post-2003 Ocean Drilling: Washington, DC (Joint Oceanographic Institutions, Inc.).

Natland, J.H., and Dick, H.J.B., 1996. Melt migration through high-level gabbroic cumulates of the East Pacific Rise at Hess Deep: the origin of magma lenses and the deep crustal structure of fast-spreading ridges. In Mével, C., Gillis, K.M., Allan, J.F., and Meyer, P.S. (Eds.), Proc. ODP, Sci. Results, 147: College Station, TX (Ocean Drilling Program), 21-58.

Natland, J.H., Adamson, A.C., Laverne, C., Melson, W.G., and O'Hearn, T., 1983. A compositionally nearly steadystate magma chamber at the Costa Rica Rift: evidence from basalt glass and mineral data, Deep Sea Drilling Project Sites 501, 504, and 505. In Cann, J.R., Langseth, M.G., Honnorez, J., Von Herzen, R.P., White, S.M., et al., Init. Repts. DSDP, 69: Washington (U.S. Govt. Printing Office), 811-858.

Ocean Drilling Program, 1996. Understanding Our Dynamic Earth through Ocean Drilling: Ocean Drilling Program Long Range Plan Into the 21st Century: Washington (Joint Oceanographic Institutions).

Parsons, B., and Sclater, J.G., 1977. An analysis of the variation of ocean floor bathymetry and heat flow with age. J. Geophys. Res., 82:803-827.

Pearce, J.S. and Cann, J.R., 1971. Ophiolite origin investigated by discriminant analysis using Ti, $\mathrm{Zr}$ and Y. Earth Planet Sci. Lett. 12, 339-349.

Pearce, J.A., Alabaster, T., Shelton, A.W. and Searle, M.P., 1981. The Oman ophiolite as a Cretaceous arc-basin complex: evidence and implications. Phil. Trans. R. Soc. London, Ser. A, 300, 299-317.

Petersen, N., Eisenach, P., and Bleil, U., 1979. Low temperature alteration of the magnetic minerals in ocean floor basalts. In Talwani, M., Harrison, C.G., and Hayes, D. (Eds.), Deep Drilling Results in the Atlantic Ocean: Ocean Crust. Am. Geophys. Union, Maurice Ewing Ser., 2:169209.

Phipps Morgan, J., and Chen, Y.J., 1993. The genesis of oceanic crust: magma injection, hydrothermal circulation, and crustal flow. J. Geophys. Res., 98:6283-6297.

Pisias, N.G., and Delaney, M.L. (Eds.), 1999. Conference on Multiple Platform Exploration of the Ocean (COMPLEX): Washington, DC (Joint Oceanographic Institutions, Inc.).

Purdy, G.M., Kong, L.S.L., Christeson, G.L., and Solomon, S.C., 1992. Relationship between spreading rate and the seismic structure of mid-ocean ridges. Nature (London, $U$. K.), 355:815-872. doi:10.1038/355815a0

Raitt, R.W., 1963. The crustal rocks. In Hill, M.N. (Ed.), The Sea-Ideas and Observations on Progress in the Study of the
Seas (Vol. 3): The Earth Beneath the Sea: New York (WileyInterscience), 85-102.

Rautenschlien, M., Jenner, G.A., Hertogen, J., Hoffmann, A.W., Kerrich, R., Schmincke, H.U., and White W.M., 1985. Isotopic and trace element composition of volcanic glasses from Akaki Canyon, Cyprus: implications for the origin of the Troodos ophiolite. Earth Planet Sci. Lett., 75:369-383.

Richardson, C.J., Cann, J.R., Richards, H.G., and Cowan, J.G., 1987. Metal-depleted root zones of the Troodos ore-forming hydrothermal systems, Cyprus. Earth Planet. Sci. Lett., 84:243-253. doi:10.1016/0012821X(87)90089-6

Schiffman, P., and Smith, B.M., 1988. Petrology and oxygen isotope geochemistry of a fossil seawater hydrothermal system within the Solea Graben, northern Troodos ophiolite, Cyprus. J. Geophys. Res., 93:4612-4624.

Shor, E.N., 1985. A chronology from Mohole to JOIDES. In Drake, E.T., and Jordan, W.M. (Eds.), Geologists and Ideas: A History of North American Geology. Geol. Soc. Spec. Publ., 4:391-399.

Singh, S.C., Kent, G.M., Collier, J.S., Harding, A.J., and Orcutt, J.A., 1998. Melt to mush variations in crustal magma properties along the ridge crest at the southern East Pacific Rise. Nature (London, U. K.), 394:874-878. doi:10.1038/29740

Stewart, M.A., Karson, J.A., and Klein, E.M., 2005. Fourdimensional upper crustal construction at fast-spreading mid-ocean ridges: a perspective from an upper crustal cross-section at the Hess Deep Rift. J. Volcanol. Geotherm. Res., 144:287-309. doi:10.1016/j.jvolgeores.2004.11.026

Su, Y., and Langmuir, C.H., 2003. Global MORB chemistry compilation at segment scale [Ph.D. dissert.]. Columbia Univ.

Teagle, D.A.H., Alt, J.C., and Halliday, A.N., 1998. Tracing the chemical evolution of fluids during hydrothermal recharge: constraints from anhydrite recovered in ODP Hole 504B. Earth Planet. Sci. Lett., 155:167-182. doi:10.1016/S0012-821X(97)00209-4

Teagle, D.A.H., Bickle, M.J., and Alt, J.C., 2003. Recharge flux to ocean-ridge black smoker systems: a geochemical estimate from ODP Hole 504B. Earth Planet. Sci. Lett., 210:81-89. doi:10.1016/S0012-821X(03)00126-2

Tong, C.H., White, R.S., Warner, M.R., and ARAD Working Group, 2004. Effects of tectonism and magmatism on crack structure in oceanic crust: a seismic anisotropy study. Geology, 32(1):25-28. doi:10.1130/G19962.1

Umino S., Miyashita, S., Hotta, F., and Adachi, Y., 2003. Along-strike variation of the sheeted dike complex in the Oman ophiolite: insights into subaxial ridge segment structures and the magma plumbing system. Geochem., Geophys., Geosyst., 4(9):8618. doi:10.1029/ 2001GC000233

Umino, S., Obata, S., and Lipman, P.W., 2000. Subaqueous lava flow lobes, observed on ROV KAIKO dives off Hawaii. Geology, 28:503-506. doi:10.1130/00917613(2000)028<0503: SLFLOO>2.3.CO;2 
Umino, S., Obata, S., Lipman, P., Smith, J.R., Shibata, T., Naka, J., and Trusdell, F., 2002. Emplacement and inflation structures of submarine and subaerieal pahoehoe lavas from Hawaii. In Takahashi, E., et al. (Eds.), Hawaiian Volcanoes: Deep Underwater Perspectives. Geophys. Monogr., 128:85-101.

Vanko, D., and Laverne, C., 1998. Hydrothermal anorthitization of plagioclase within the magmatic/hydrothermal transition at mid-ocean ridges: examples from deep sheeted dikes (Hole 504B, Costa Rica Rift) and a sheeted dike root zone (Oman ophiolite). Earth Planet. Sci. Lett., 162:27-43. doi:10.1016/S0012-821X(98)00155-1

Varne, R., Brown, A.V., and Fallon, T., 2000. Macquarie Island: its geology, structural history, and the timing and tectonic setting of its N-MORB to E-MORB magnetism. In Dilek, Y., Moores, E.M., Elthon, D., and Nicolas, A. (Eds.), Ophiolites and Oceanic Crust: New Insights from Field Studies and the Ocean Drilling Program. Spec. Pap.Geol. Soc. Am., 349:301-320.

Vine, F.J., and Matthews, D.H., 1963. Magnetic anomalies over oceanic ridges. Nature (London, U. K.), 199:947-949.

White, S.M., Hayman, R.M., Fornari, D.J., Perfit, M.R., and Macdonald, K.C., 2002. Correlation between volcanic and tectonic segmentation of fast-spreading ridges: evidence from volcanic structures and lava flow morphology on the East Pacific Rise at $9^{\circ}-10^{\circ}$ N. J. Geophys. Res., 107:2173. doi:10.1029/2001JB000571

White, S.M., Macdonald, K.C., and Haymon, R.M., 2000. Basaltic lava domes, lava lakes, and volcanic segmentation on the southern East Pacific Rise. J. Geophys. Res., 105:23519-23536. doi:10.1029/2000JB900248

Wilson, D.S., 1996. Fastest known spreading on the Miocene Cocos-Pacific plate boundary. Geophys. Res. Lett., 23:3003-3006. doi:10.1029/96GL02893

Wilson, D.S., Hallenborg, E., Harding, A.J., and Kent, G.M., 2003. Data report: site survey results from cruise EW9903. In Wilson, D.S., Teagle, D.A.H., Acton, G.D., Proc. ODP, Init. Repts., 206: College Station, TX (Ocean Drilling Program), 1-49. doi:10.2973/ odp.proc.ir.206.104.2003

Wilson, D.S., Teagle, D.A.H., Acton, G.D., 2003. Proc. ODP, Init. Repts., 206: College Station, TX (Ocean Drilling Program). doi:10.2973/odp.proc.ir.206.2003

Publication: 28 December 2006

MS 309312-101 
Figure F1. A. Basement age vs. depth of basement penetration for scientific drill holes deeper than $50 \mathrm{~m}$ drilled into in situ ocean crust formed at the mid-ocean ridges. B. Depth of penetration of drill holes into in situ basement clustered by broad spreading rate subdivisions where slow $<40 \mathrm{~mm} / \mathrm{y}<$ moderate $<80 \mathrm{~mm} / \mathrm{y}<$ fast. Note that boundaries between erupted lavas, the dike-lava transition zone, and the sheeted dike complex/upper gabbro boundary are placed at arbitrary depths based loosely on Hole 504B stratigraphy. Predictions based on marine seismic reflection studies indicate that the combined thickness of the lava-dike sequences should decrease with spreading rate but are yet to be tested, and whether it is the dikes or lavas that are thinned is so far unknown. Black lines = DSDP drill holes, dark blue lines = ODP drill holes, red lines = Holes 1256C and 1256D drilled into basement during Leg 206 and Expedition 309. For complete discussion see Wilson, Teagle, Acton, et al. (2003).

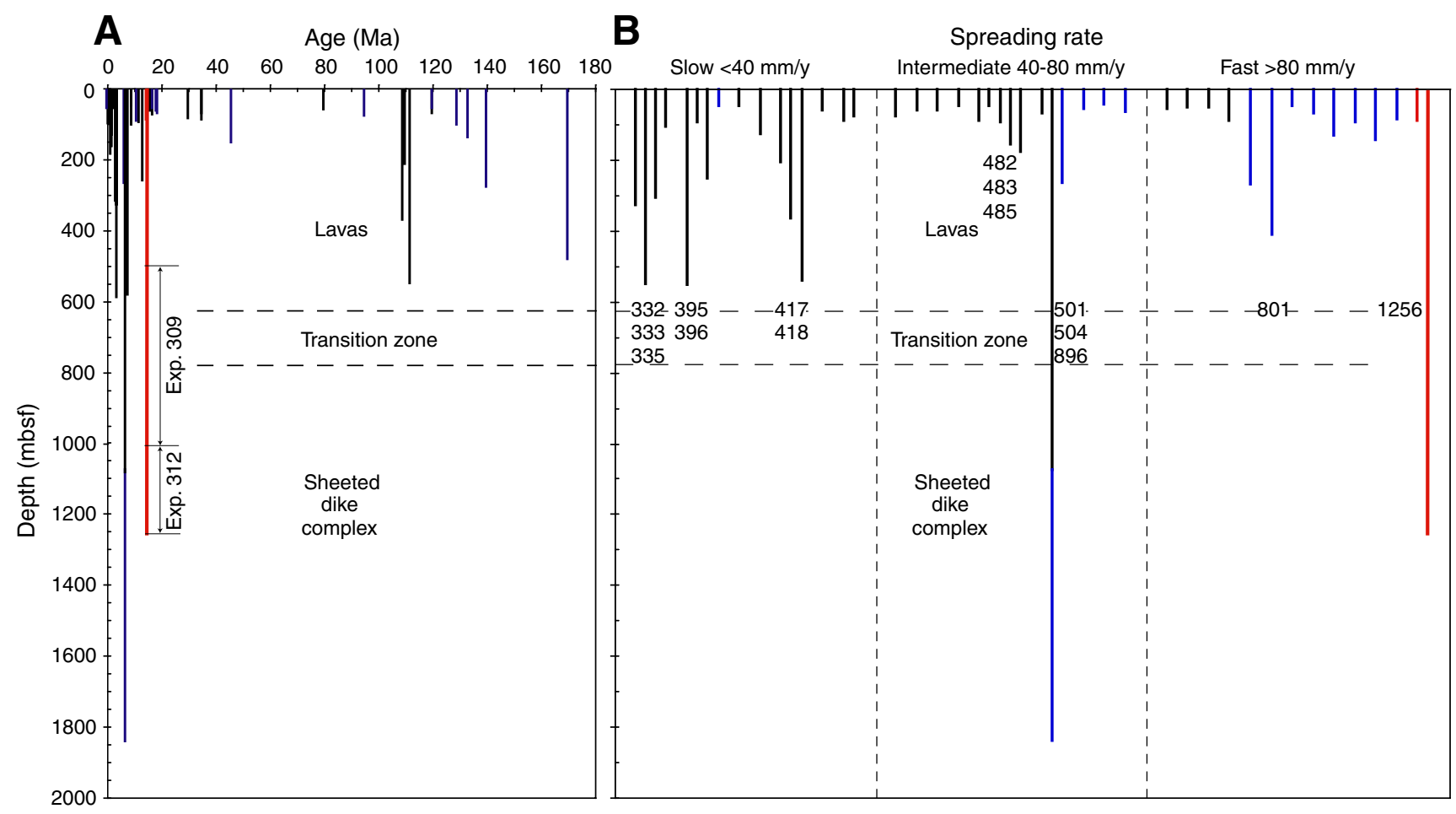


Figure F2. Age map of the Cocos plate and corresponding regions of the Pacific plate. Isochrons at 5 m.y. intervals have been converted from magnetic anomaly identifications according to the timescale of Cande and Kent (1995). Selected DSDP and ODP sites that reached basement are indicated. The wide spacing of 10$20 \mathrm{~m} . \mathrm{y}$. isochrons to the south reflects the extremely fast $(200-220 \mathrm{~mm} / \mathrm{y})$ full spreading rate (modified from Wilson, Teagle, Acton, et al., 2003). FZ = fracture zone.

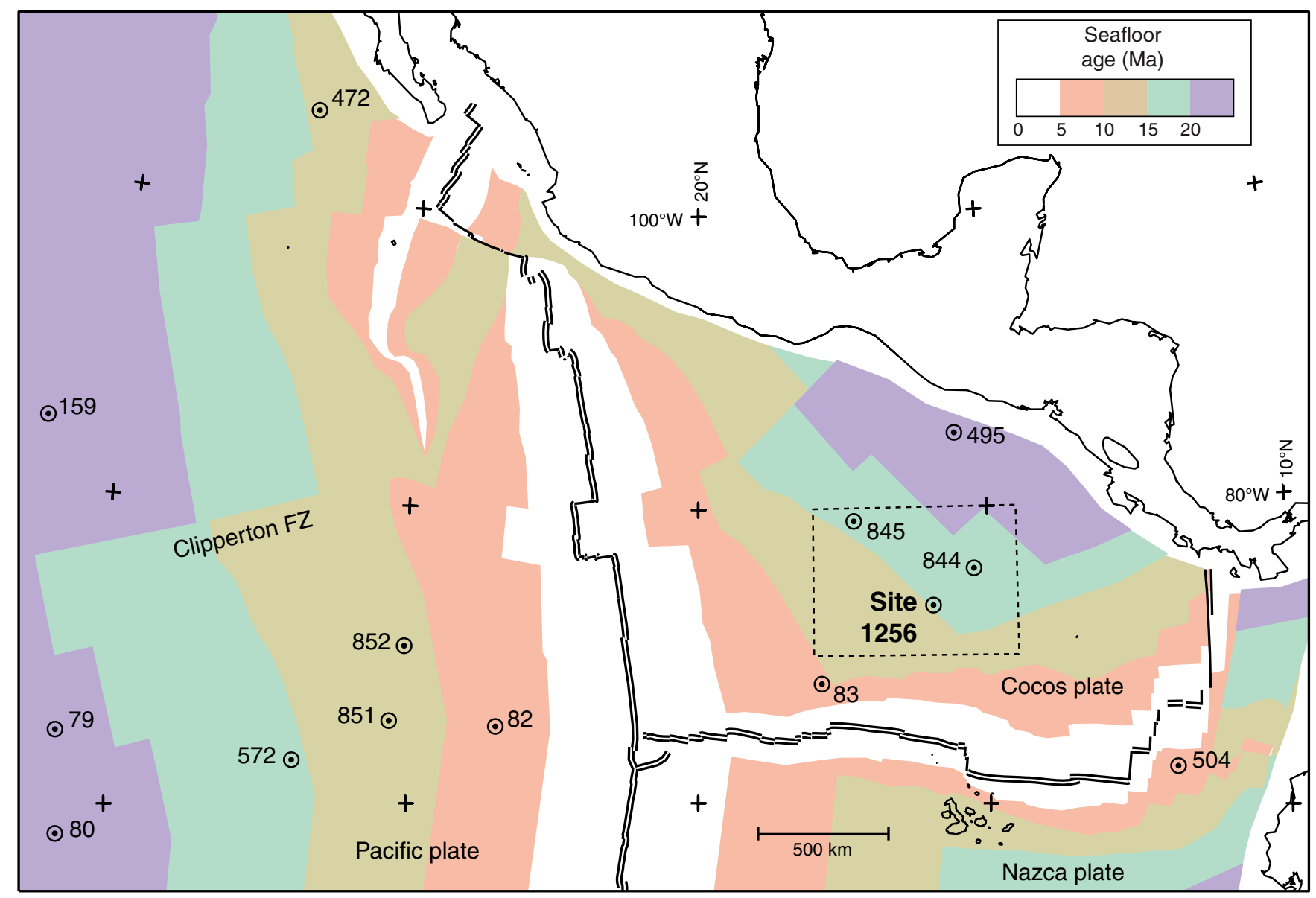


Figure F3. Depth to axial low-velocity zone plotted against spreading rate (modified from Purdy et al., 1992; Carbotte et al., 1997b). Depth vs. rate predictions from two models of Phipps Morgan and Chen (1993) are shown, extrapolated subjectively to $200 \mathrm{~mm} / \mathrm{y}$ (dashed lines). Penetration to date in Holes 504B and 1256D is shown by solid vertical lines, and planned deepening for Expedition 309/312 is indicated. MAR = Mid-Atlantic Ridge, EPR = East Pacific Rise, JdF = Juan de Fuca Ridge, Lau = Valu Fa Ridge in Lau Basin, CRR = Costa Rica Rift.

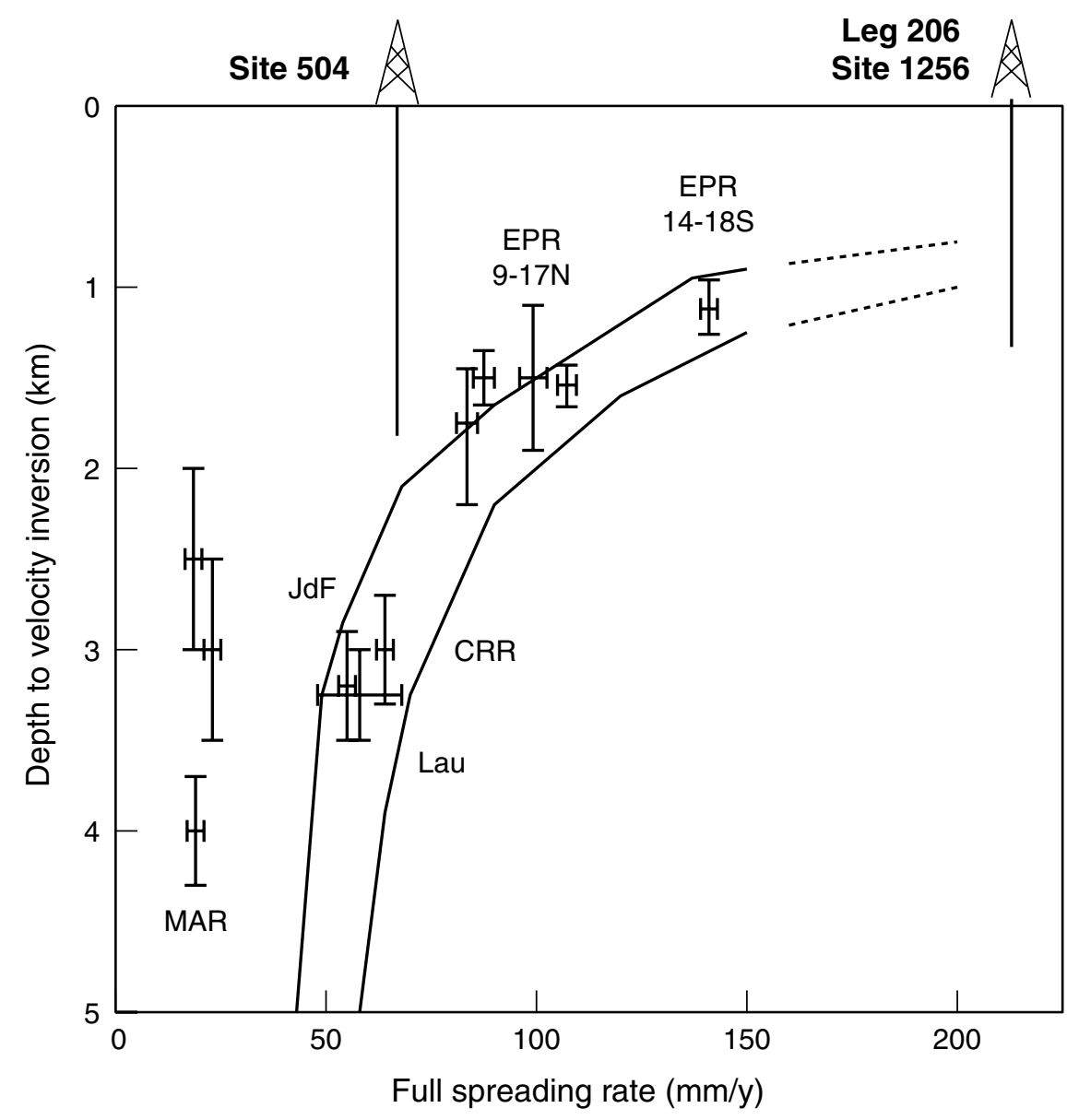


Figure F4. Reconstruction of Site 1256 and vicinity at $14 \mathrm{Ma}, \sim 1$ m.y. after formation of the site at the East Pacific Rise. Positions and plate velocities (arrows labeled in millimeters per year) are relative to the Antarctic plate, which is reasonably fixed relative to the spin axis and hotspots. Bars $=$ reconstructed positions of mapped magnetic Anomalies 5B, 5C, and 6 (ages 15-20 Ma), circles = existing DSDP/ODP drill sites.

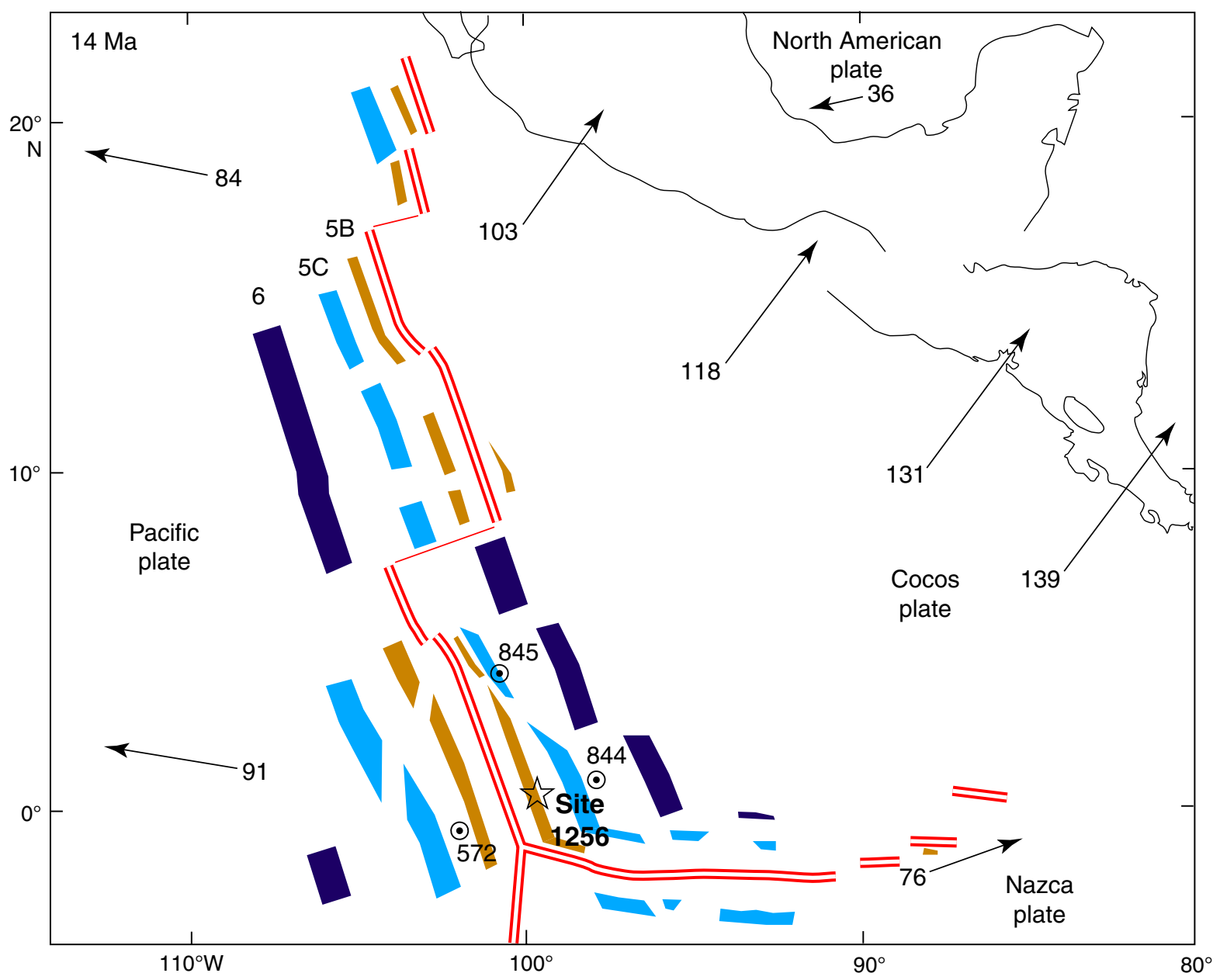


Figure F5. A. Details of isochrons inferred from magnetic anomalies near Site 1256. Shading shows normal magnetic polarity based on digitized reversal boundaries (small circles; after Wilson, 1996). Bold line shows location of Guatemala Basin (GUATB) multichannel seismic (MCS) tracklines from the site survey Cruise EW9903 conducted in March-April 1999 (Wilson et al., 2003). Anomaly ages: 5A = 12 Ma, 5B =15 Ma, 5D = $\sim 17$ Ma. B. Bathymetry and site survey track map for Site 1256 (proposed Site GUATB-03C). Abyssal hill relief of up to $100 \mathrm{~m}$ is apparent in the southwest part of the area; relief to the northeast is lower and less organized. Line numbers 21-28 identify MCS lines from the site survey. $\mathrm{OBH}=$ ocean bottom hydrophone.
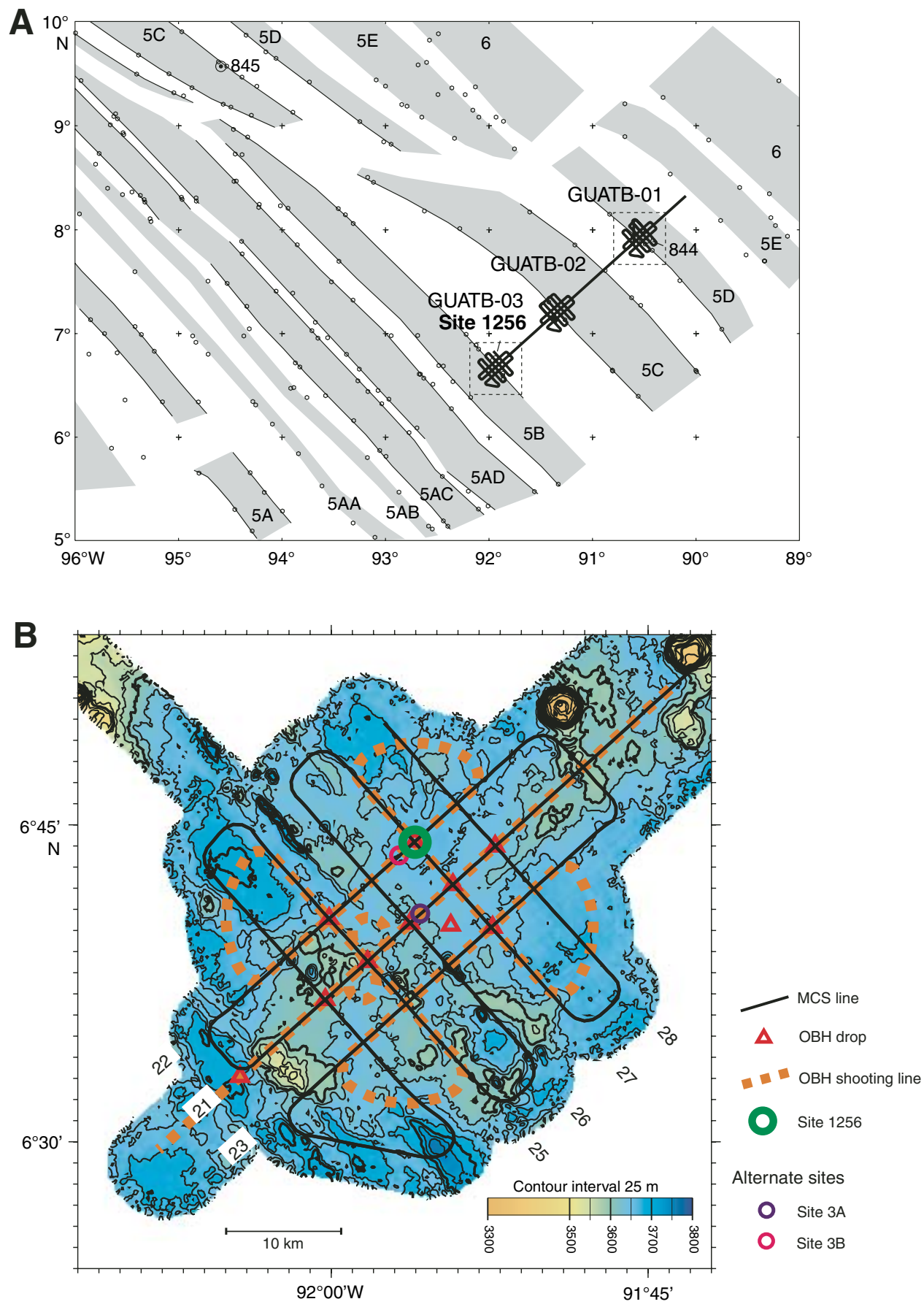
Figure F6. Site survey MCS data (Hallenborg et al., 2003) from the lines that cross at Site 1256, with penetration as of the end of Expedition 309 scaled approximately to travel time. Distances are in kilometers. Horizontal reflectors in the upper basement to travel times of $5.5 \mathrm{~s}$ appear to result from contrasts between lava flow sequences, corresponding to depths of at least $800 \mathrm{msb}$.

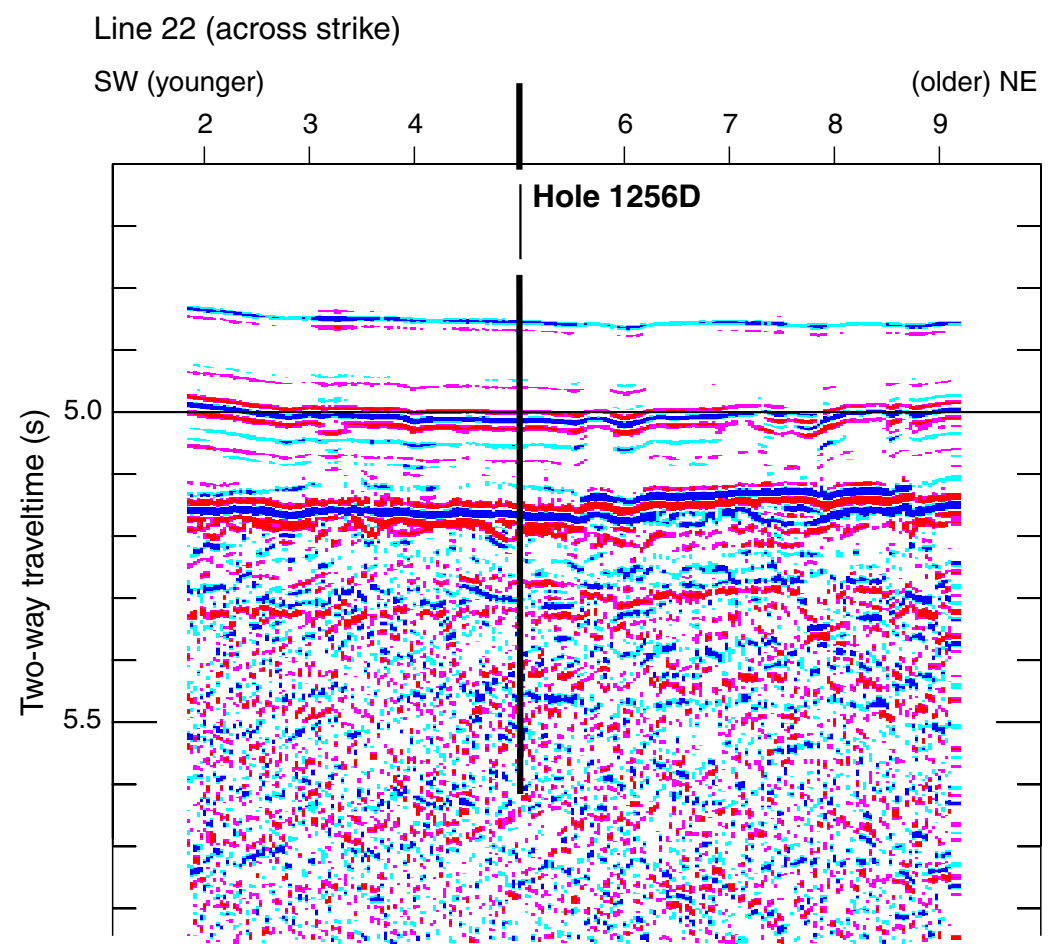

Line 27 (along strike)

SE

NW

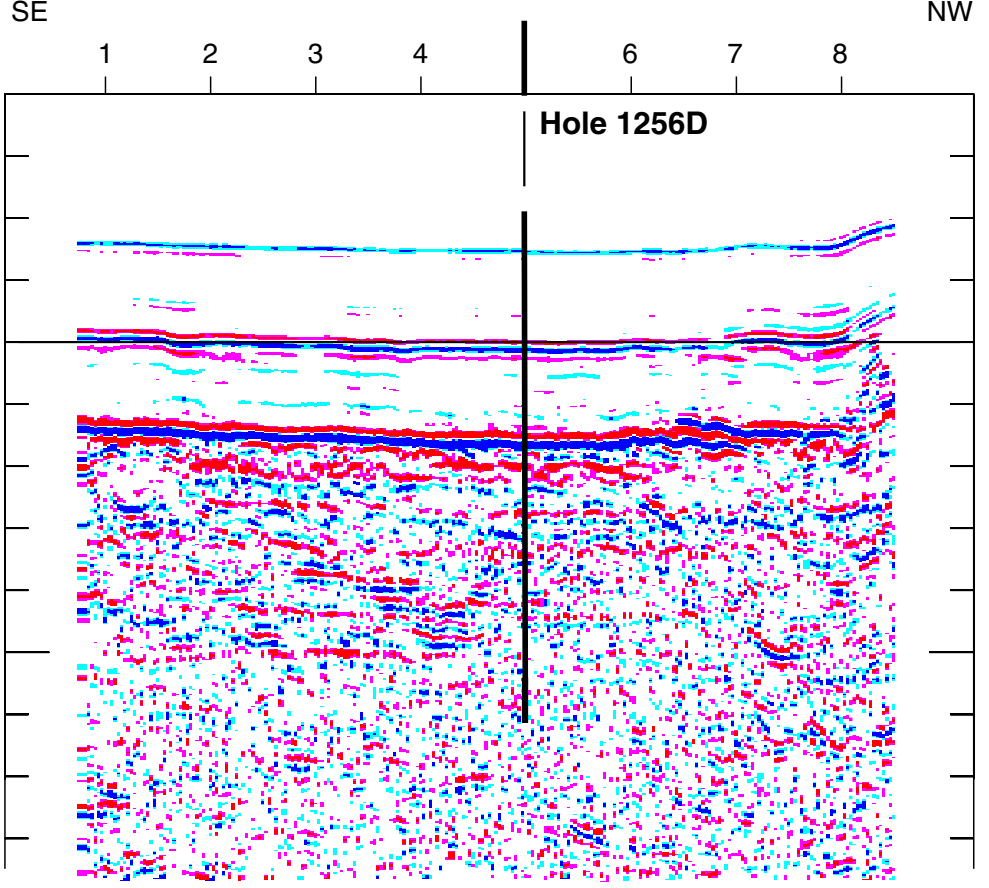


Figure F7. One-dimensional velocity model based on inversion of refraction data. At shallow depths, separate inversions were performed on northeast and southwest data subsets, with slightly faster velocities found to the northeast where abyssal hill topography is very subdued. The Layer $2 / 3$ boundary is present in the depth range 1.2-1.5 km. The velocity model of Detrick et al. (1998) for Site 504, also based on ocean bottom hydrophone refraction, is shown for comparison. Apparent differences are dominated by differences in the inversion techniques, but the differences at $1.3-1.7 \mathrm{~km}$ may be barely above uncertainty.

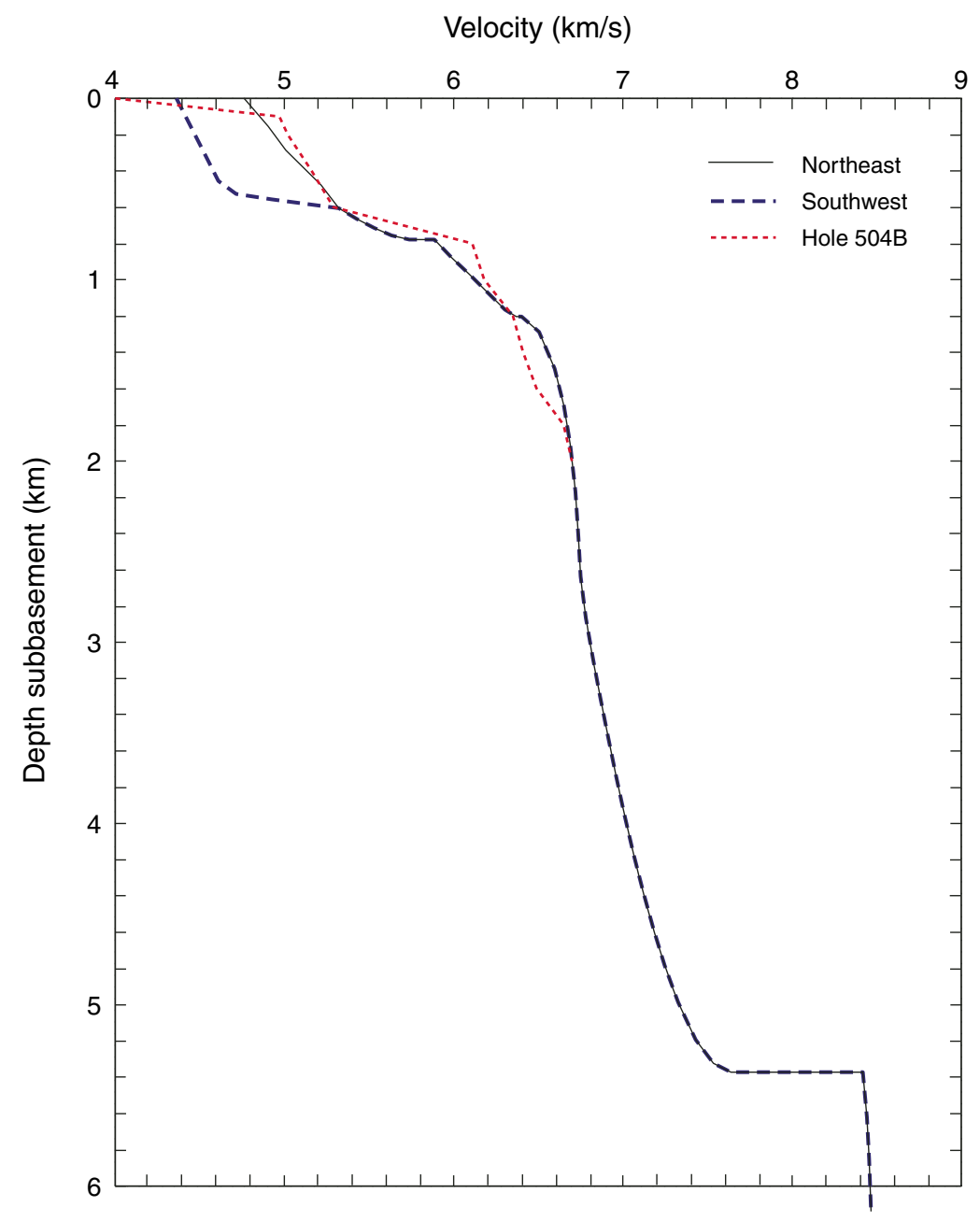


Figure F8. A. Contour map of seismic $P$-wave velocity at the top of basement, based on tomographic inversion of seismic refraction data (A. Harding, unpubl. data). The low-velocity area southwest of the center may reflect pillow lavas or other porous formation. The high-velocity area extending southeast from Site 1256 may reflect the extent of the ponded lava sequence drilled at the top of basement in Holes 1256C and 1256D. OBH = ocean bottom hydrophone. B. Geological map of Site 1256 area (GUATB-03) showing bathymetry, alternate site locations, and selected top-of-basement velocity contours from A. The larger velocity contour line partially encloses velocity $>4.82 \mathrm{~km} / \mathrm{s}$, which we interpret as a plausible proxy for the presence of thick ponded lava flows, as encountered at Site 1256. The smaller contour encloses velocities $<4.60 \mathrm{~km} / \mathrm{s}$, possibly reflecting a greater portion of pillow lavas than elsewhere in the region. Alternate reentry Sites 3D and 3E are 0.5-1.0 km from Site 1256.
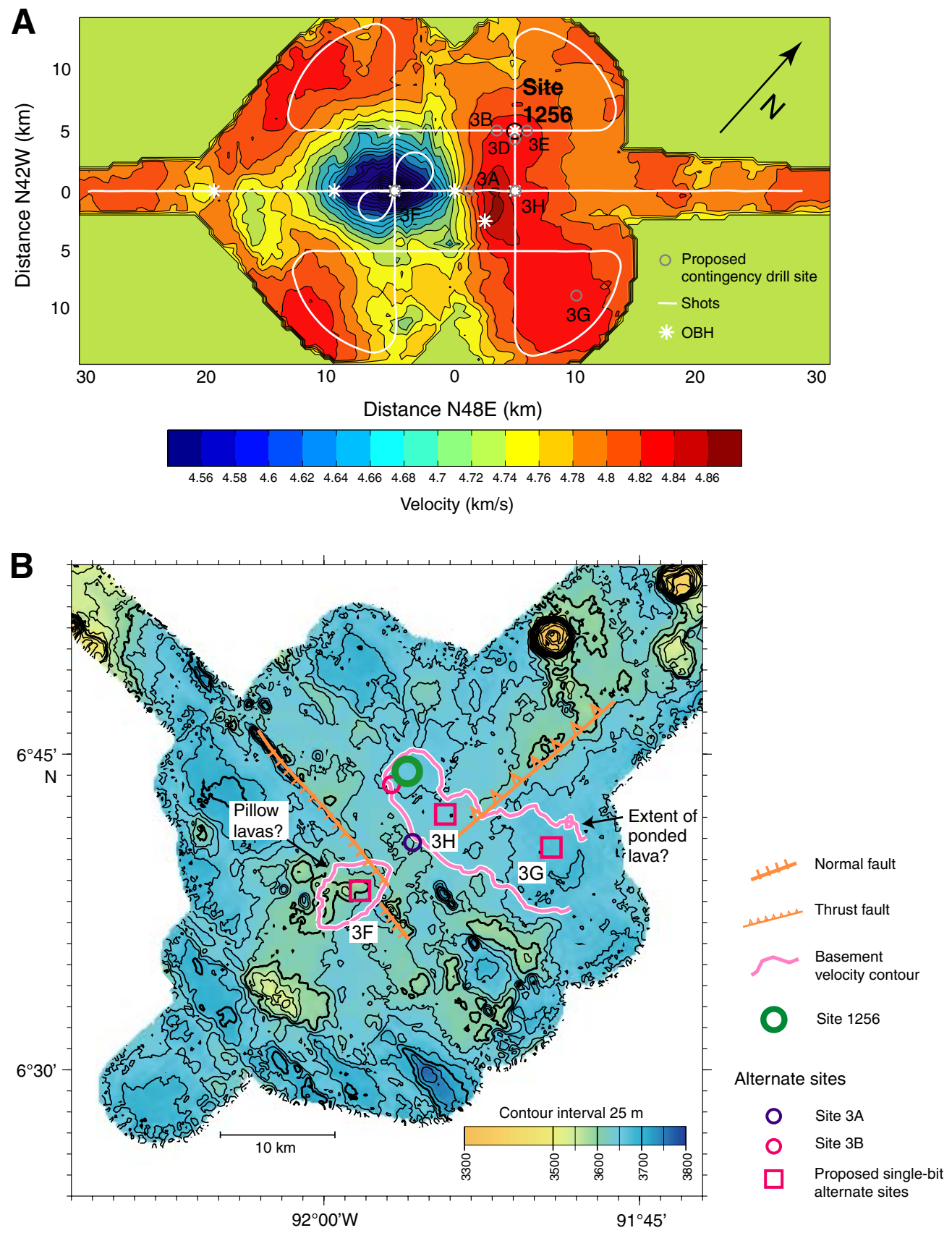
Figure F9. Recovery and lithology schematics and selected chemical and logging results for basement in Holes 1256C and 1256D during Leg 206 (Wilson, Teagle, Acton, et al., 2003).

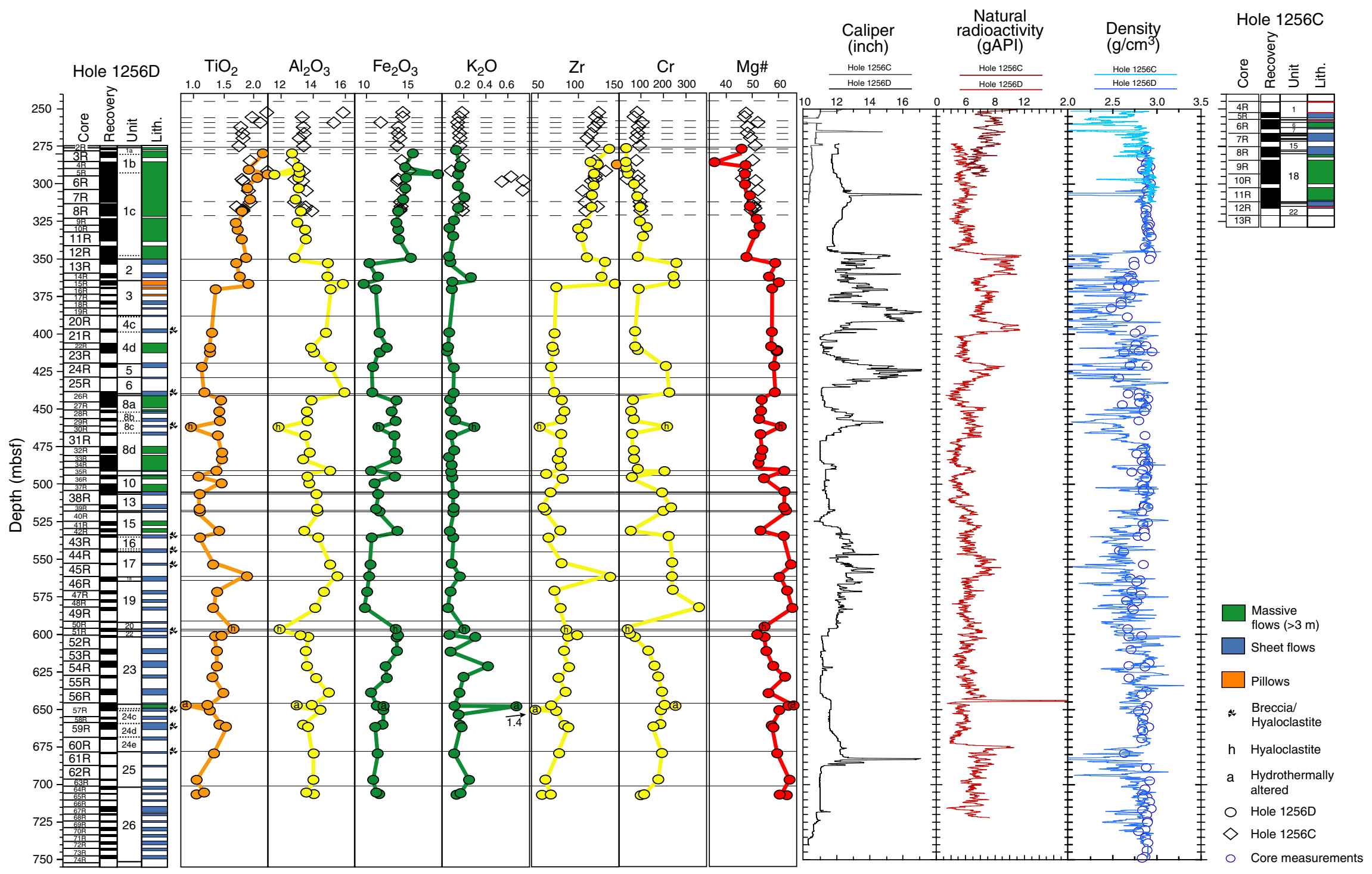


Figure F10. Distribution of alteration zones with depth in selected ODP basement sections compared to Hole 1256D (after Alt, 2004).

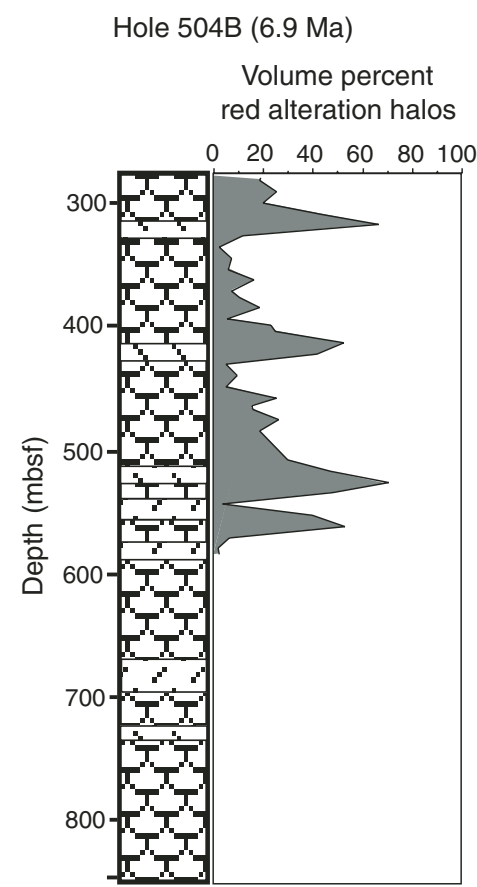

Hole 896A (6.9 Ma)

Volume percent

red alteration halos

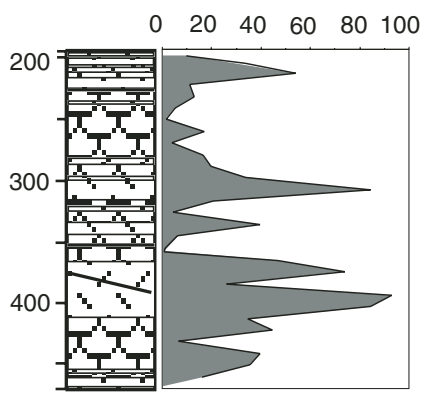

Pillows and flows

. Massive units

Breccia

$\boxminus$ Sheet flows
Hole 1149D (135 Ma)

Volume percent

red alteration halos
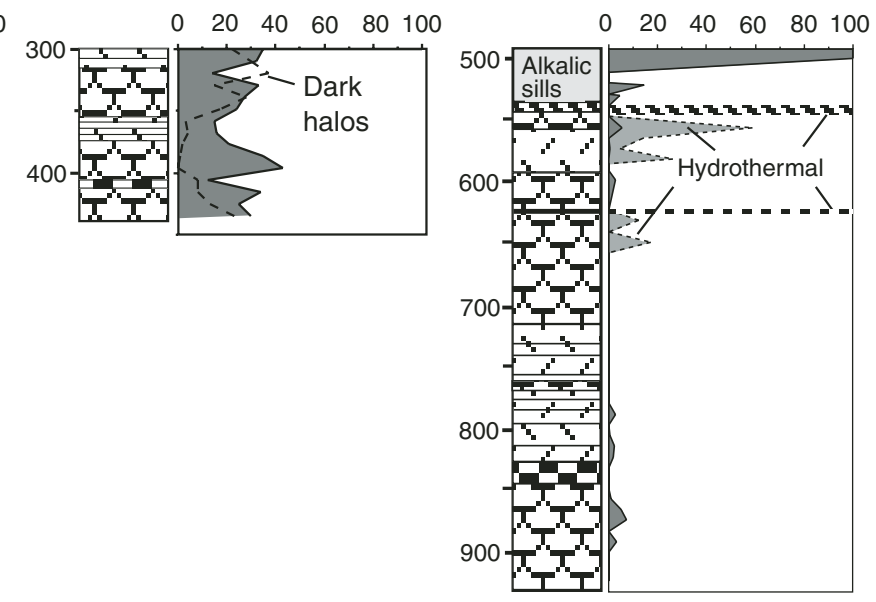

Hole 1256D (15 Ma)

Volume percent

alteration halos

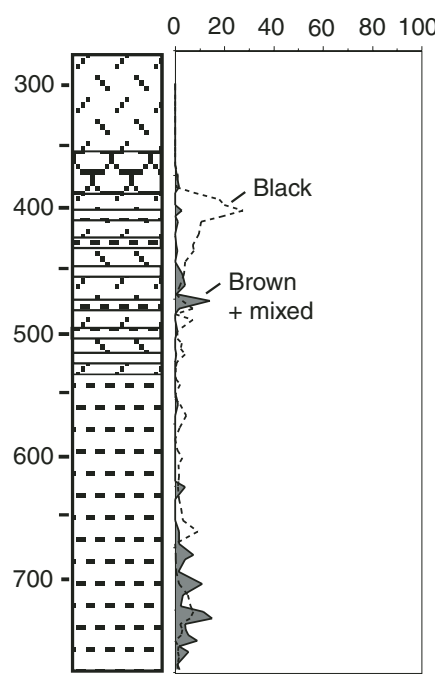


Figure F11. Depth vs. time predicted for drilling and wireline logging operations for Expedition 309/312. Black line $=$ depth of Hole 1256D before operations during Expedition 309. Horizontal lines $=$ range of depths at which axial low-velocity zones, now frozen as gabbros, should be present, assuming $300 \mathrm{~m}$ of off-axis lavas (see Table T2). RCB = rotary core barrel.

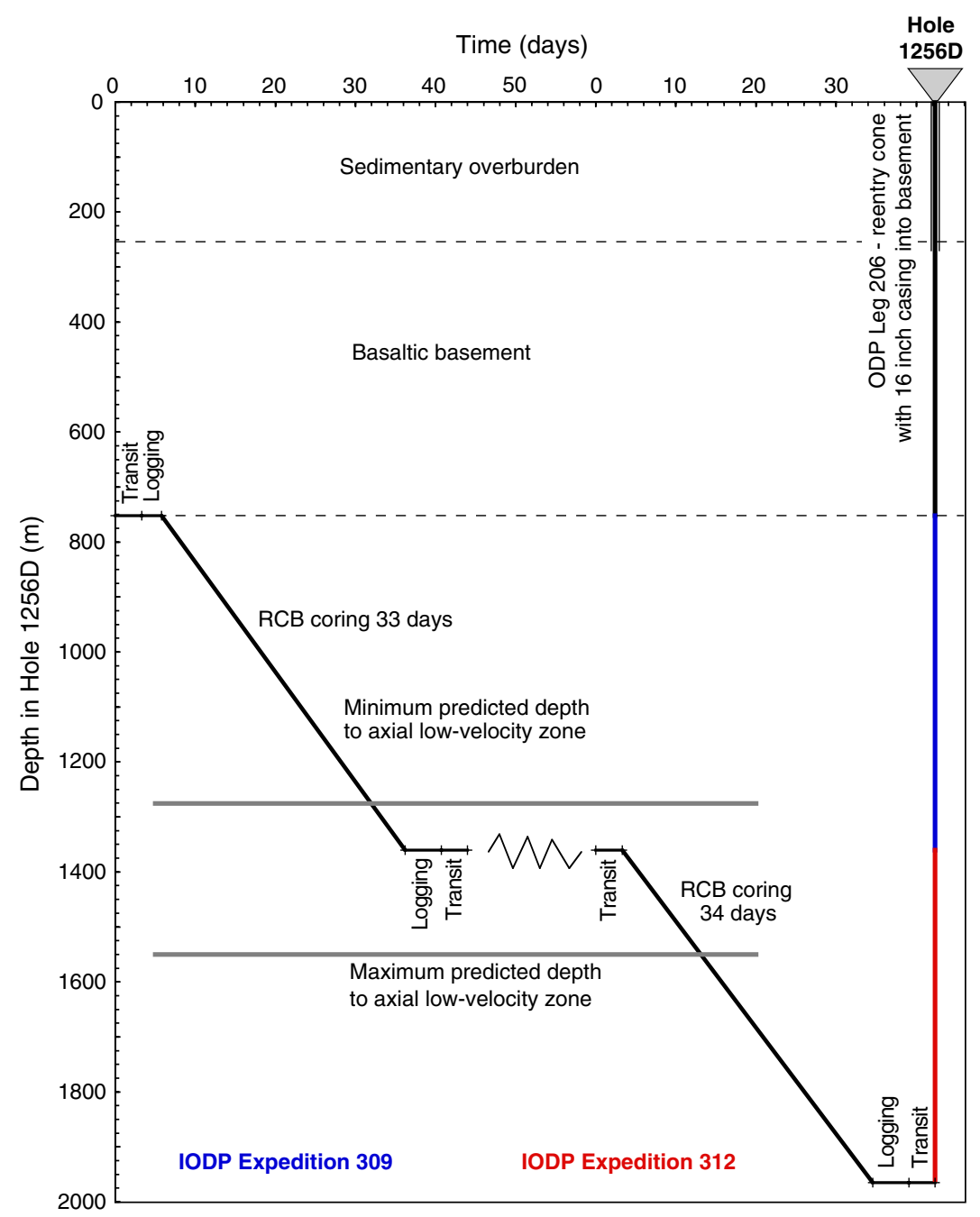


Figure F12. Drilling progress in Hole 1256D during Leg 206 and Expedition 309/312. Generalized lithostratigraphy is shown on the left. The minimum and maximum predicted target depths to gabbros are also shown.

Days in Hole 1256D

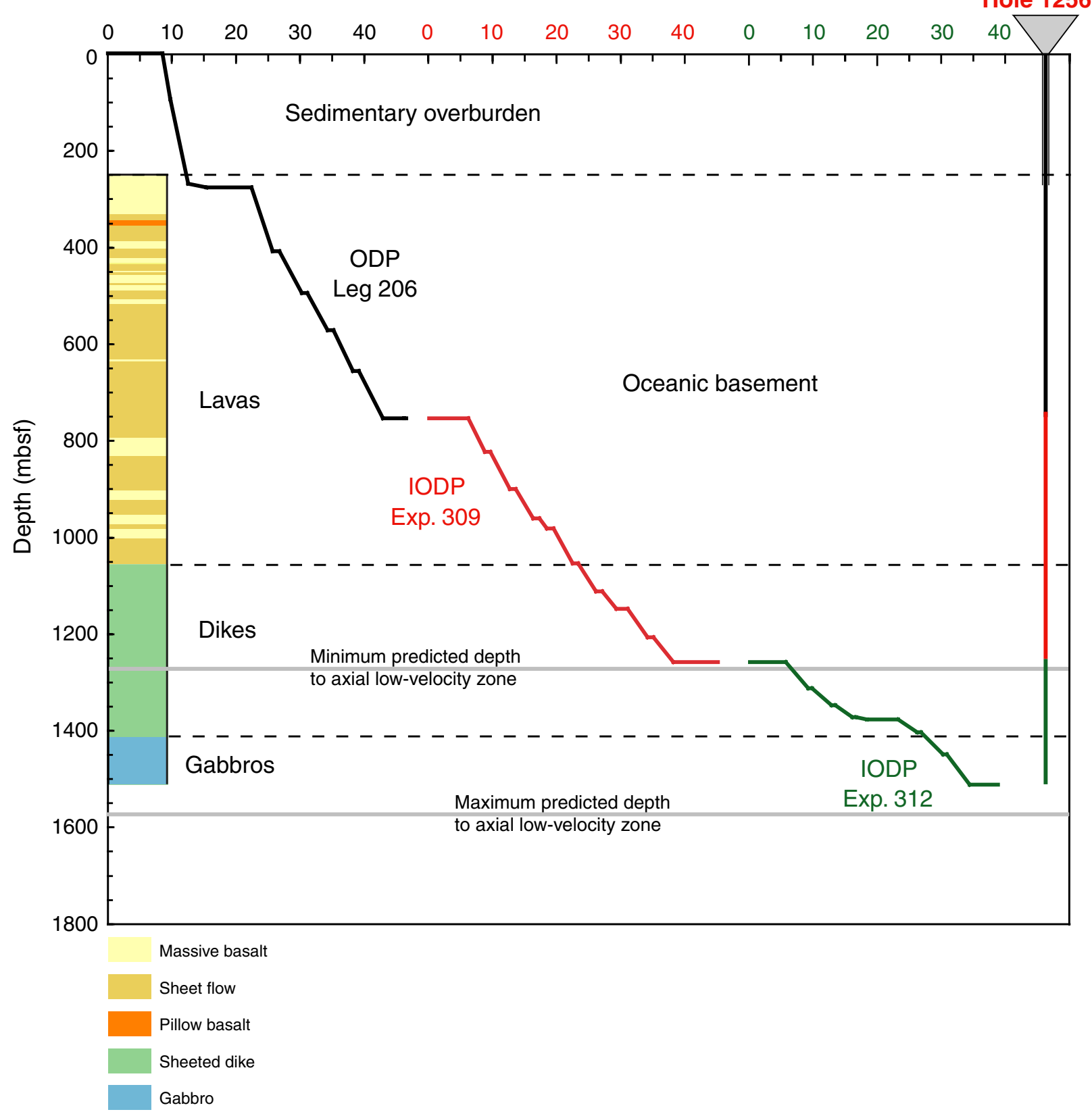


Figure F13. Average rates of recovery and penetration (ROP) for drilling in Hole 1256D (see Table T3). Note the improvement in both parameters in gabbroic rocks back to near-average rates for the entire hole (recovery $=\sim 36 \%$; ROP $=\sim 1.2 \mathrm{~m} / \mathrm{h}$ ). Recovery was very low and penetration excruciatingly slow in the granoblastic dikes.

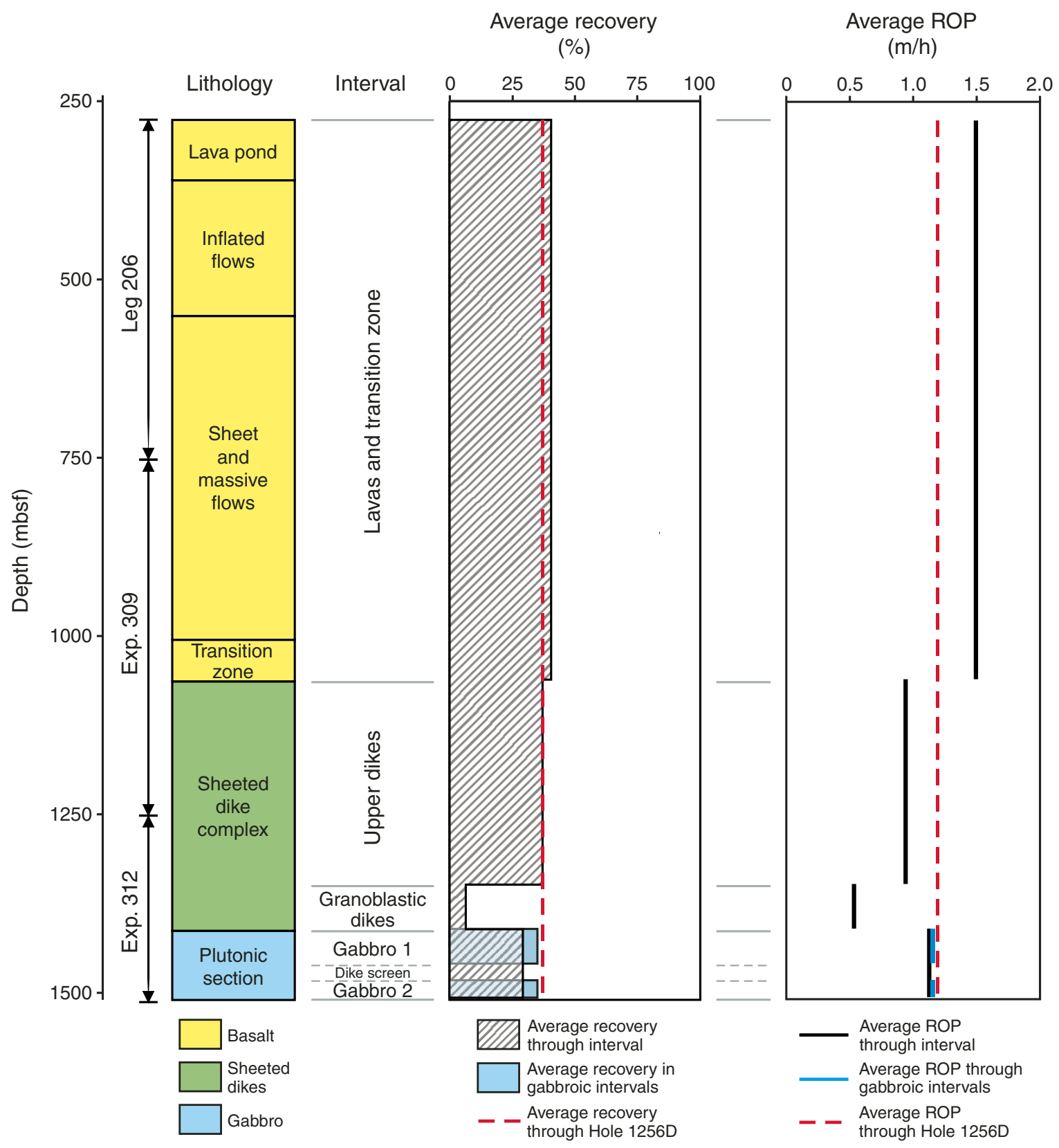


Figure F14. Boreholes $>200 \mathrm{~m}$ deep drilled into in situ ocean crust by DSDP, ODP, and IODP compared to Hole $1256 \mathrm{D}$. Hole 504B is the only other basement hole to sample a complete extrusive sequence and penetrate into the sheeted dikes. ODP Hole 735B and IODP Hole U1309D, which drilled deeply into gabbros tectonically exposed near ridge-transform intersections on the Southwest Indian Ridge and Mid-Atlantic Ridge, respectively, are shown for comparison. $\mathrm{LP}=$ lava pond, Inflate $=$ inflated flows, Sheet and mass flows $=$ sheet and massive flows, $\mathrm{TZ}=$ transition zone, $\mathrm{Gb}=$ gabbroic rocks, $\mathrm{msb}=$ meters subbasement. See Table $\mathrm{T} 4$ for description and basis for these subdivisions.

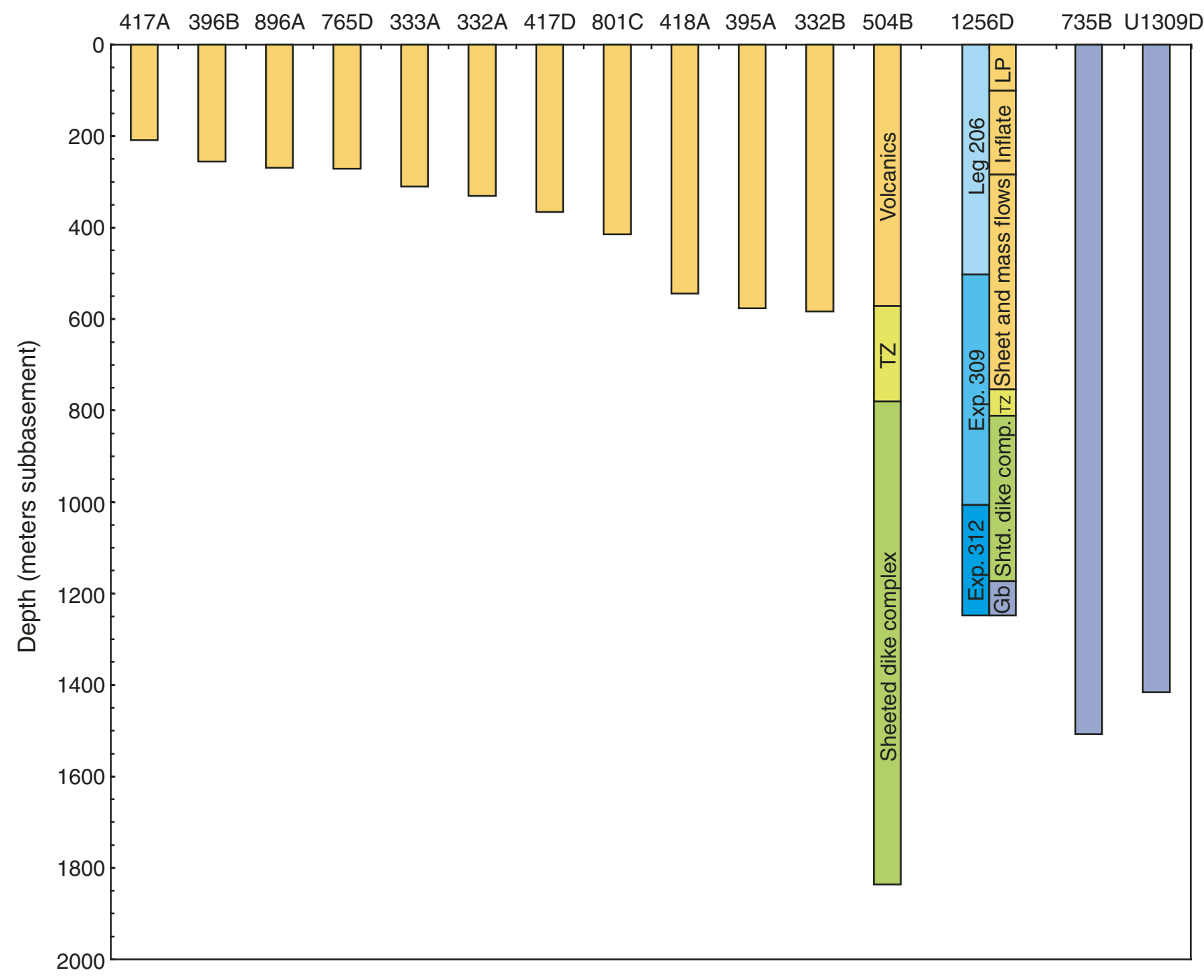


Figure F15. Simplified igneous stratigraphy of Hole 1256D, showing dominant rock types and preliminary subdivisions of the upper crust.

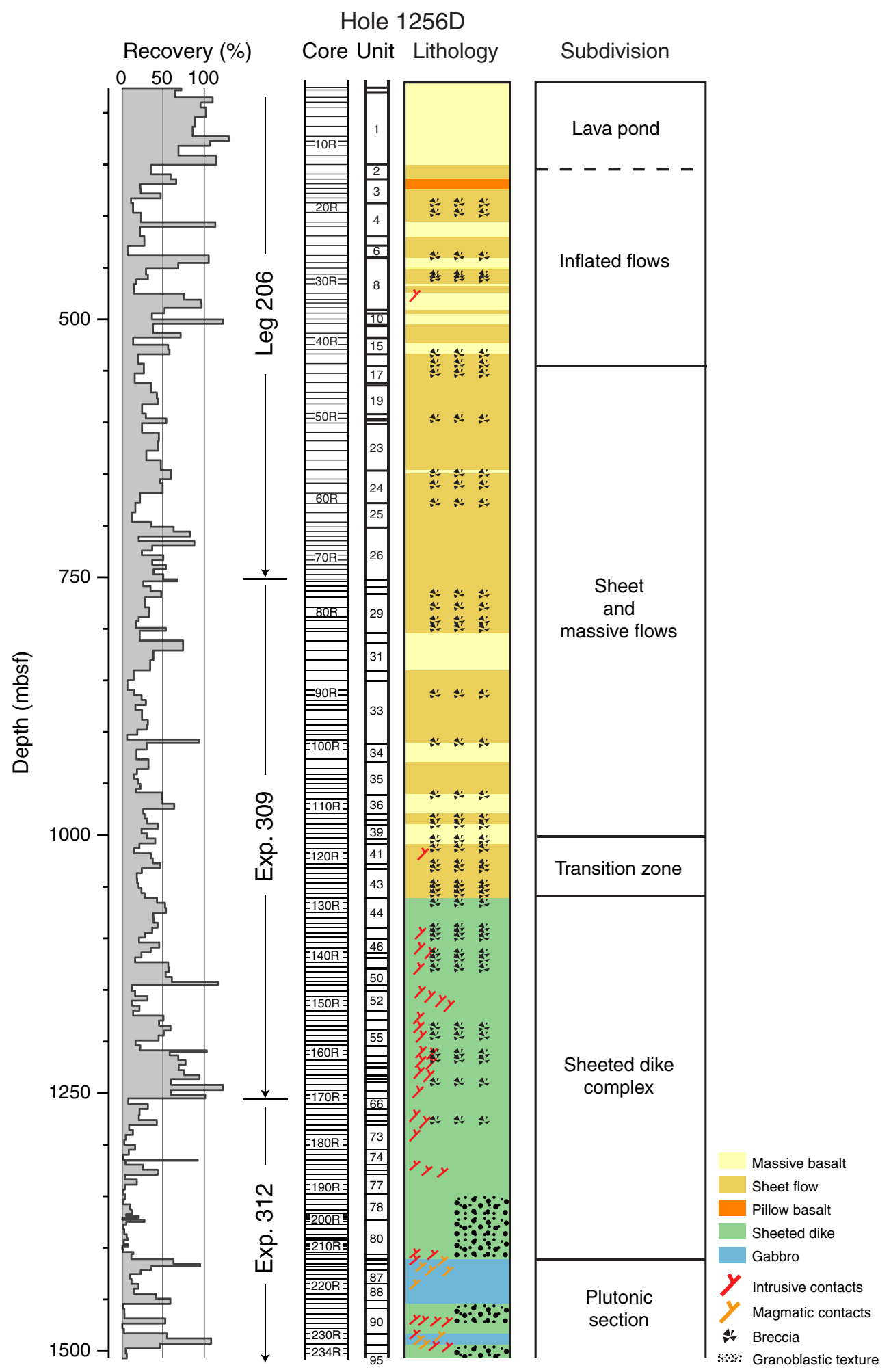


Figure F16. Basement stratigraphy in Hole 1256D showing (from left) depth scale, core numbers, recovered intervals, unit and subunit boundaries, igneous lithology, locations of glass and altered glass (solid/stippled line), groundmass grain size, and phenocryst percentage based on thin section descriptions. $\mathrm{cx}=$ cryptocrystalline, $\mu \mathrm{x}=$ microcrystalline, $\mathrm{fg}=$ fine grained, $\mathrm{ol}=$ olivine, $\mathrm{plag}=$ plagioclase, $\mathrm{cpx}=$ clinopyroxene. Leg 206 stratigraphy is slightly revised according to Leg 206 visual core description records. (Continued on next page.)

Hole 1256D
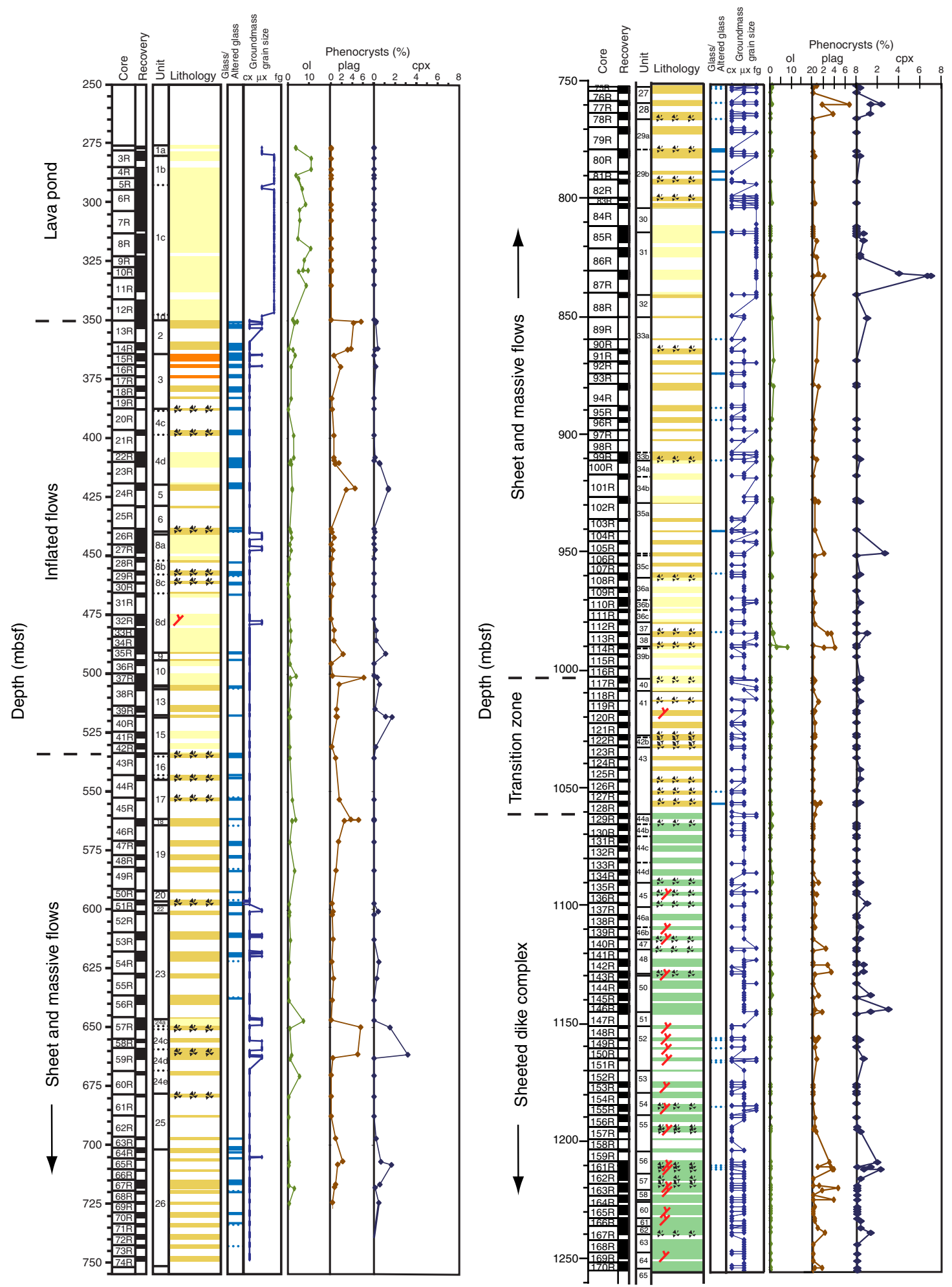
Figure F16 (continued). Basement stratigraphy in Hole 1256D.

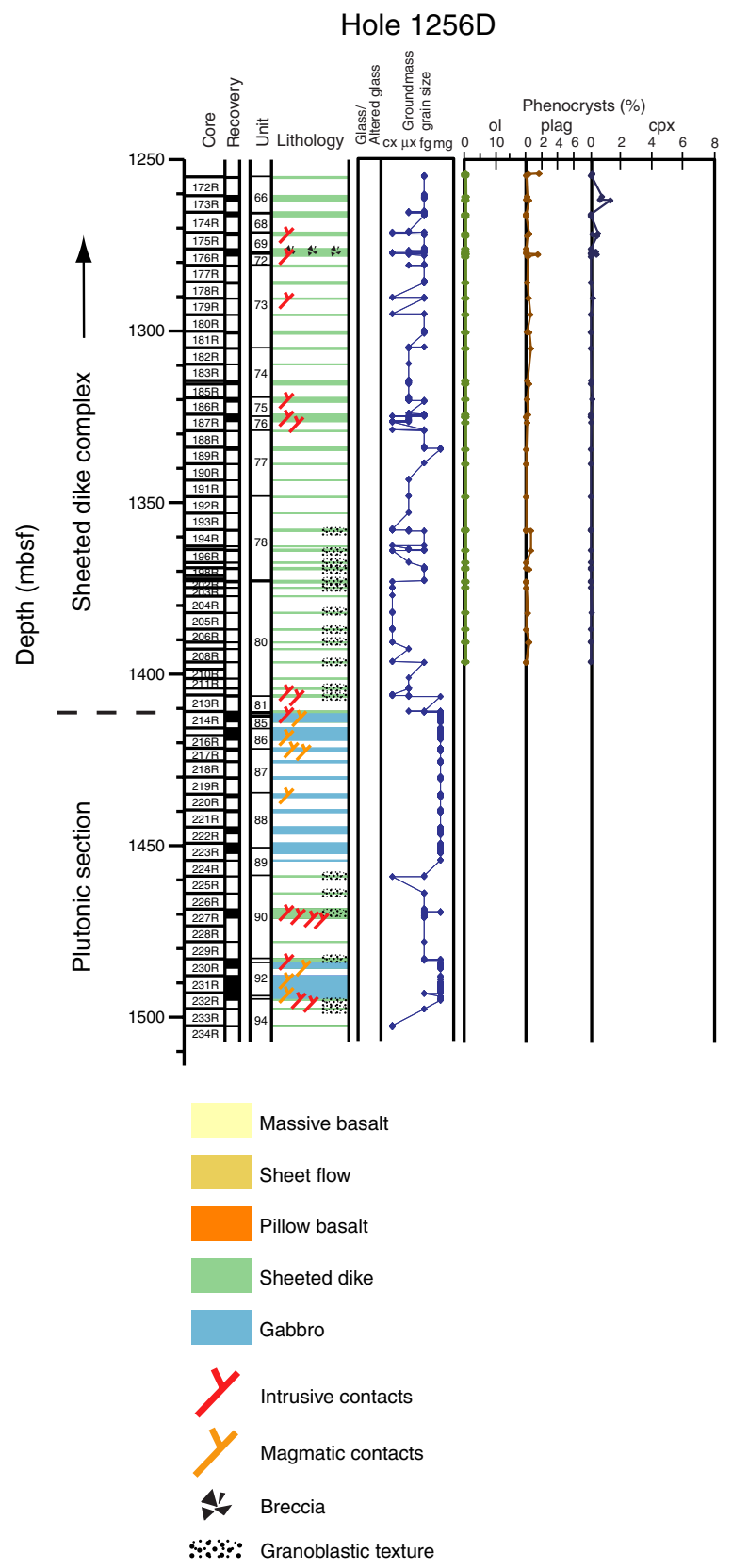


Figure F17. Aphyric cryptocrystalline to microcrystalline basalt typical for the interior of sheet flows (Unit 1256D-29a) (interval 309-1256D-79R-2, 37-50 cm).

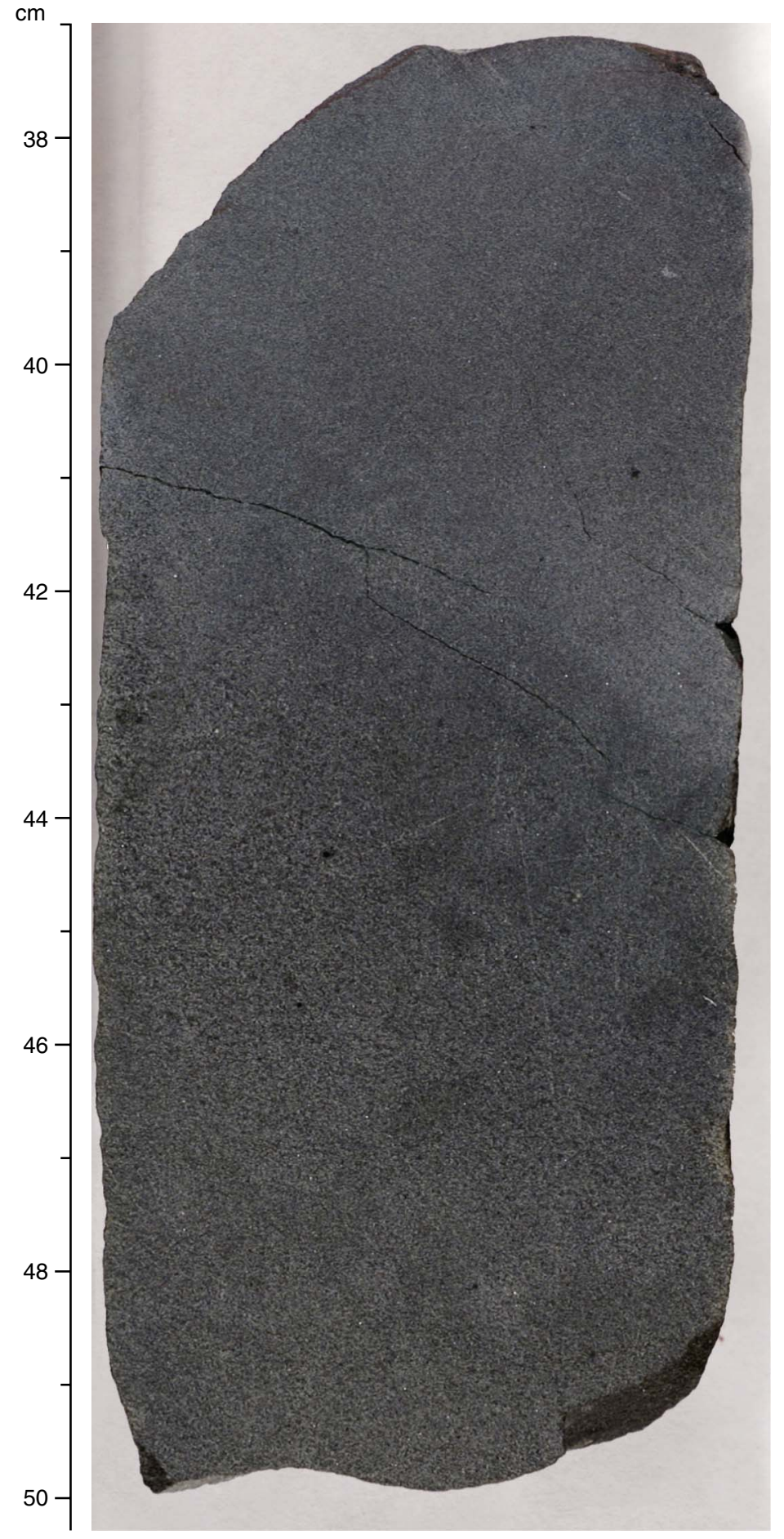


Figure F18. Sparsely olivine-clinopyroxene-plagioclase phyric microcrystalline basalt sheet flow (Unit 1256D28) (interval 309-1256D-77R-2, 20-32 cm).

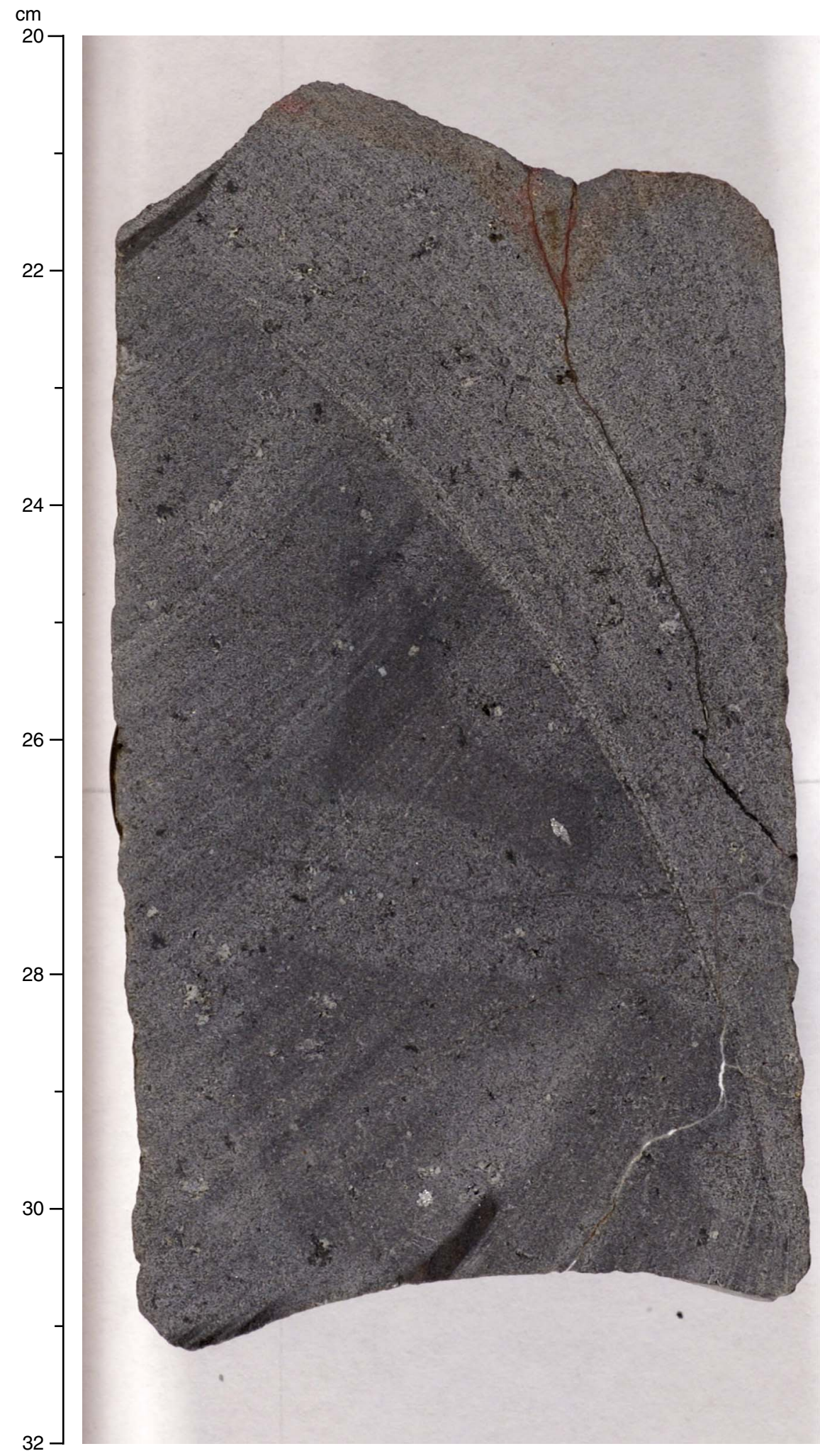


Figure F19. Holocrystalline fine-grained gabbroic xenolith in an aphyric microcrystalline basaltic sheet flow (Unit 1256D-35c) (interval 309-1256D-108R-1, 30-36 cm). The xenolith consists of olivine, plagioclase, and clinopyroxene minerals. Cavities within the xenolith are filled with the aphyric microcrystalline basalt of the host rock.

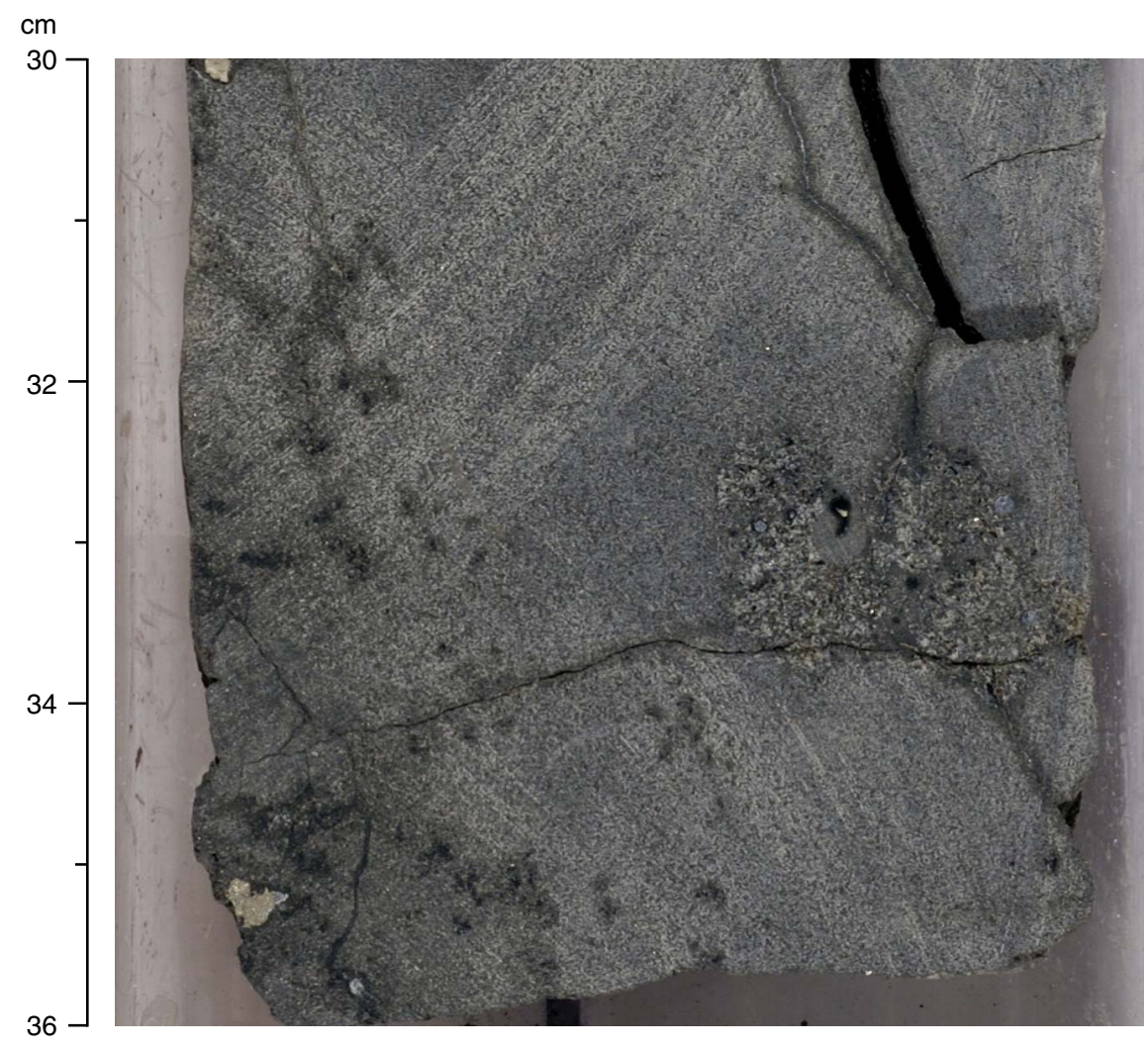


Figure F20. Typical aphyric fine-grained massive basalt (Unit 1256D-30) (interval 309-1256D-85R-1, 120-139 $\mathrm{cm})$.

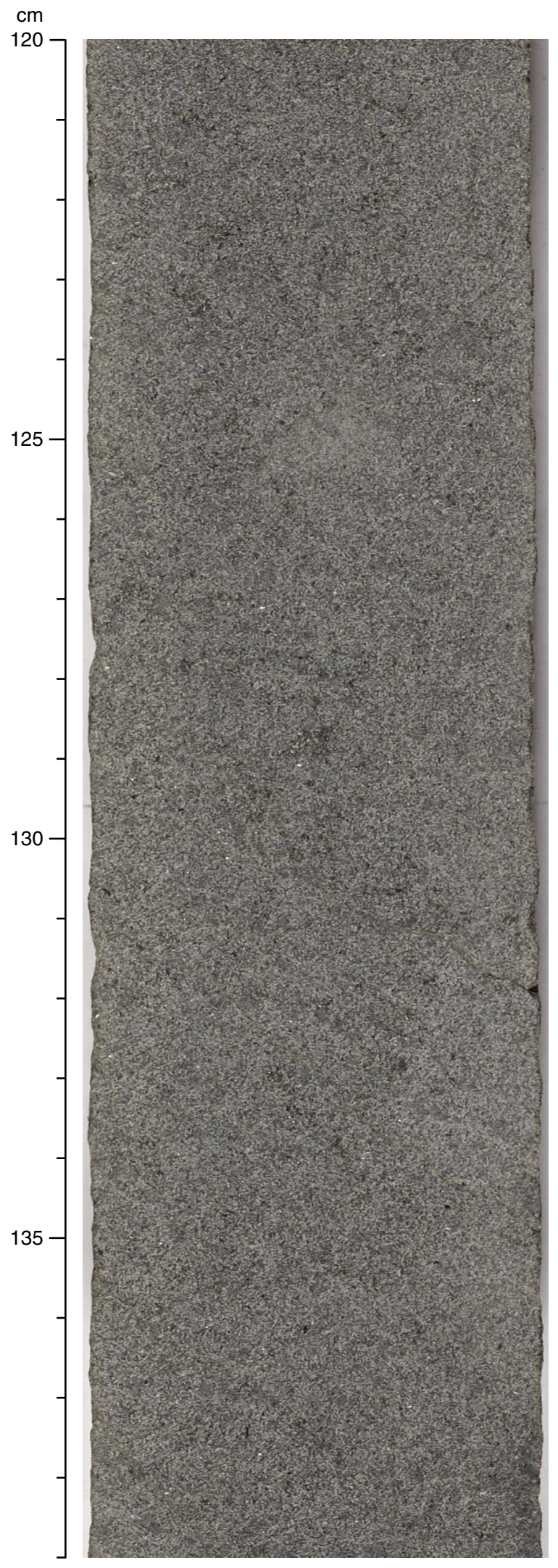


Figure F21. Sparsely plagioclase-olivine phyric moderately vesicular microcrystalline basalt (Unit 1256D-39a) (interval 309-1256D-114R-1, 128-143 cm). Note the dark olivine phenocrysts and the spherical vesicle, filled with saponite.

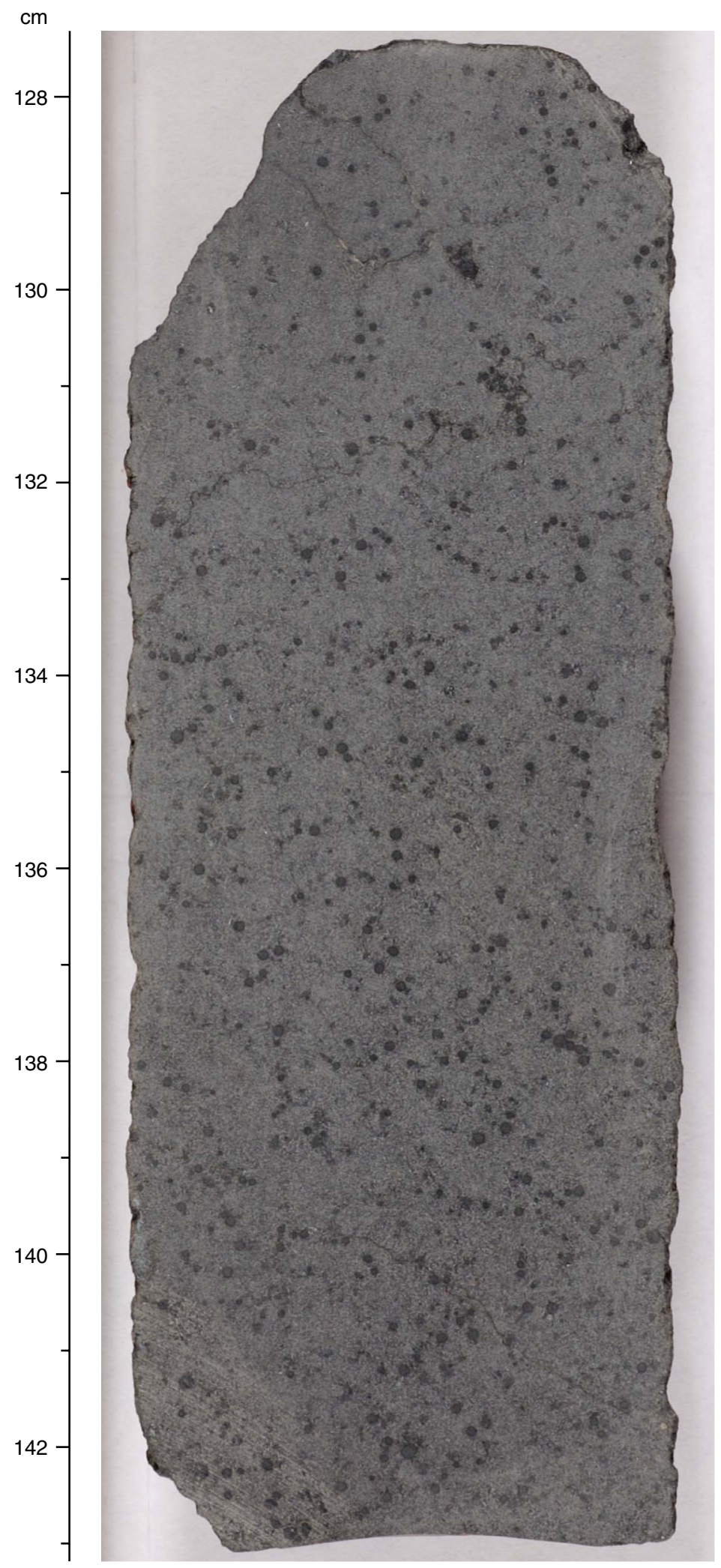


Figure F22. Intergranular texture in massive fine-grained basalt (Thin Section 28; Sample 309-1256D-86R-3, 94-97 cm) (cross-polarized light; field of view $=5.0 \mathrm{~mm}$ ).

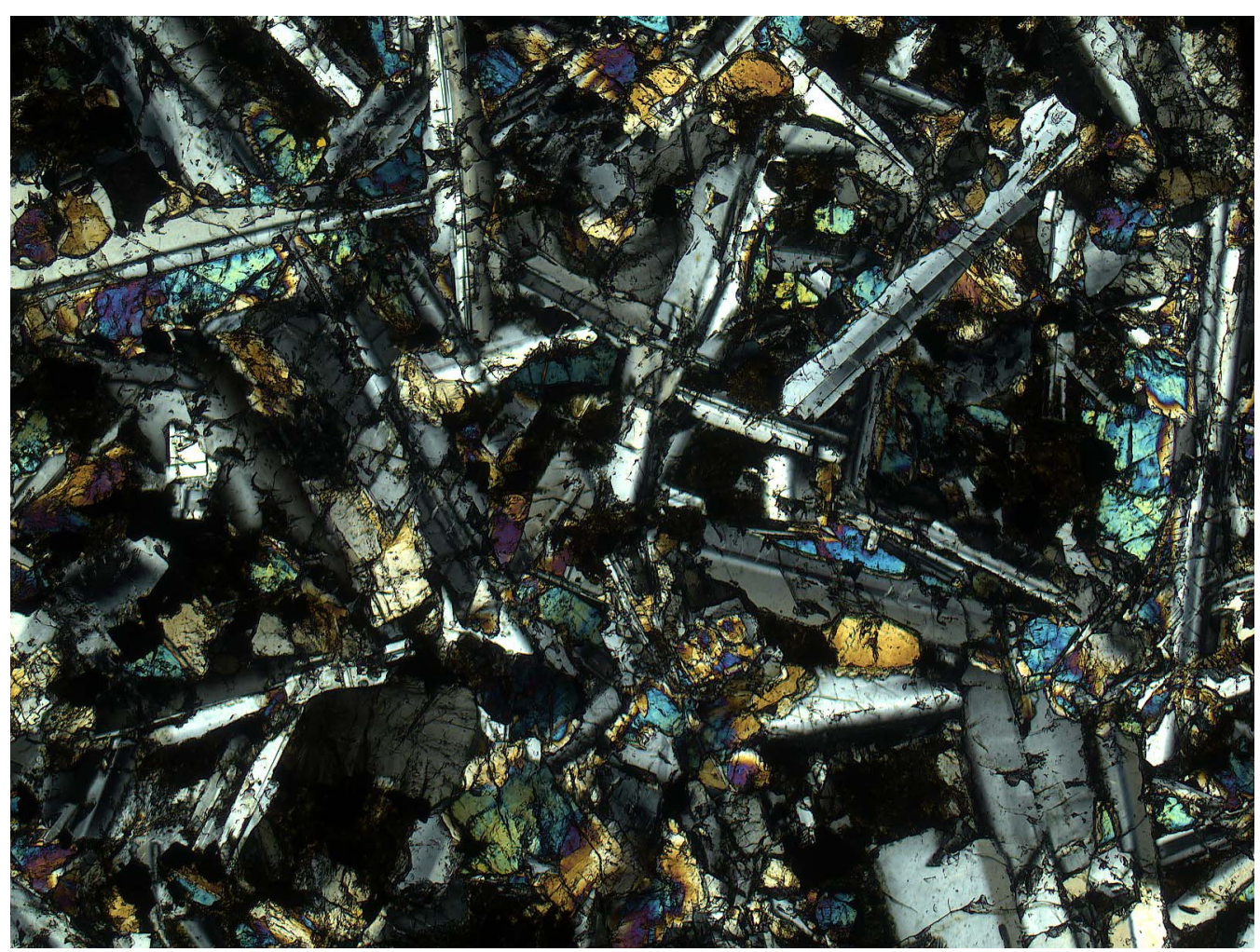


Figure F23. Cryptocrystalline basalt clasts (left edge) embedded in fine- to medium-grained cataclastic massive unit (1256D-40) (interval 309-1256D-117R-1, 121-131 cm).

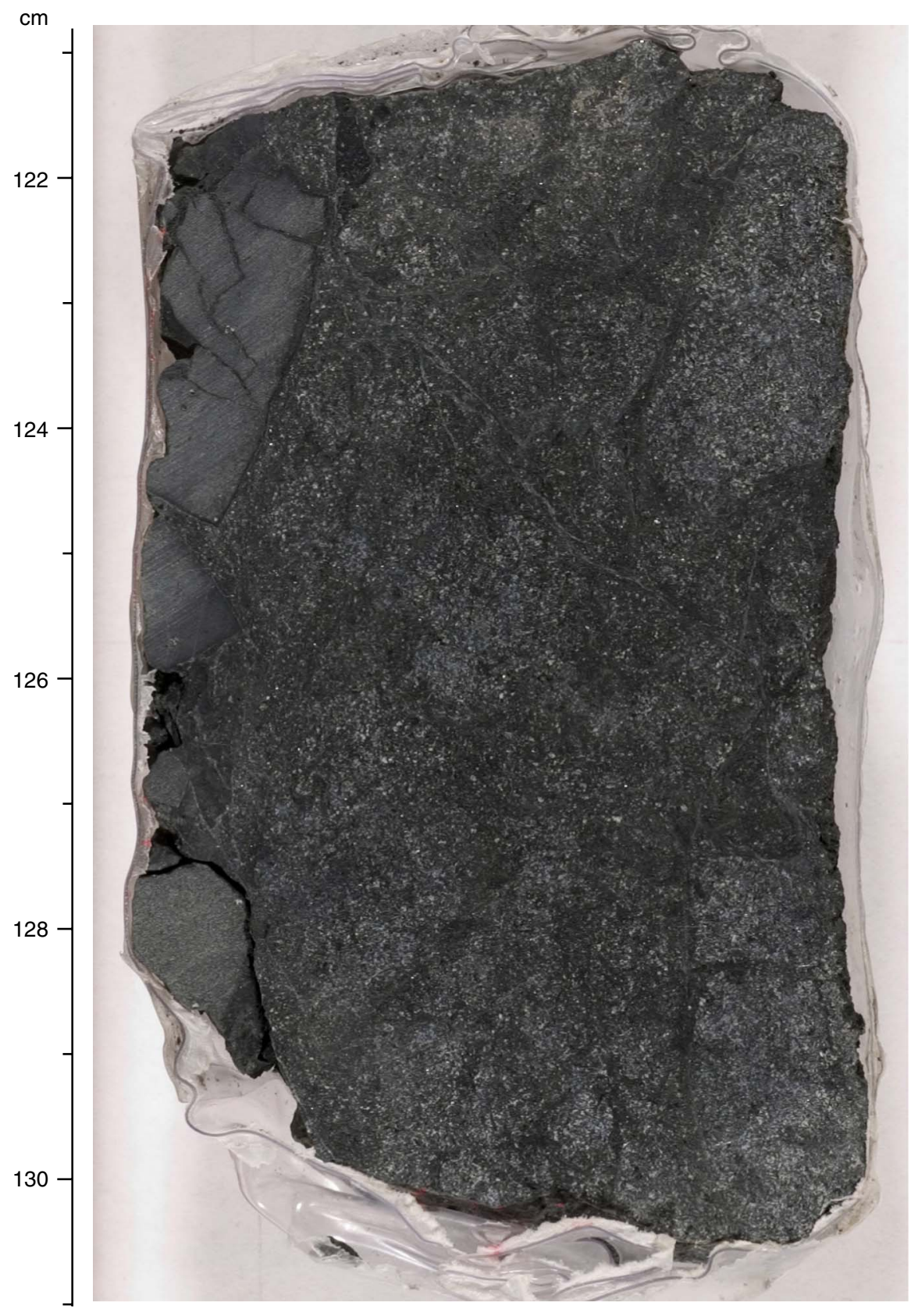


Figure F24. Mineralized volcanic breccia (Unit 1256D-42a) and volcanic breccia interbedded with sheet flow (Unit 1256D-42b). Breccia consists of angular fragments of glassy to cryptocrystalline basalt embedded in altered glass, sulfides, and late carbonate. Pieces indicated by arrows in Unit 1256D-42b are brecciated. A. Interval 309-1256D-122R-1 (Piece 12, 50-66 cm). B. Interval 309-1256D-122R-1 (Piece 13, 67-80 cm). C. Interval 309-1256D-123R-1 (Piece 4, 15-20 cm). D. Interval 309-1256D-122R-2 (Pieces 2 and 3, 15-30 cm).

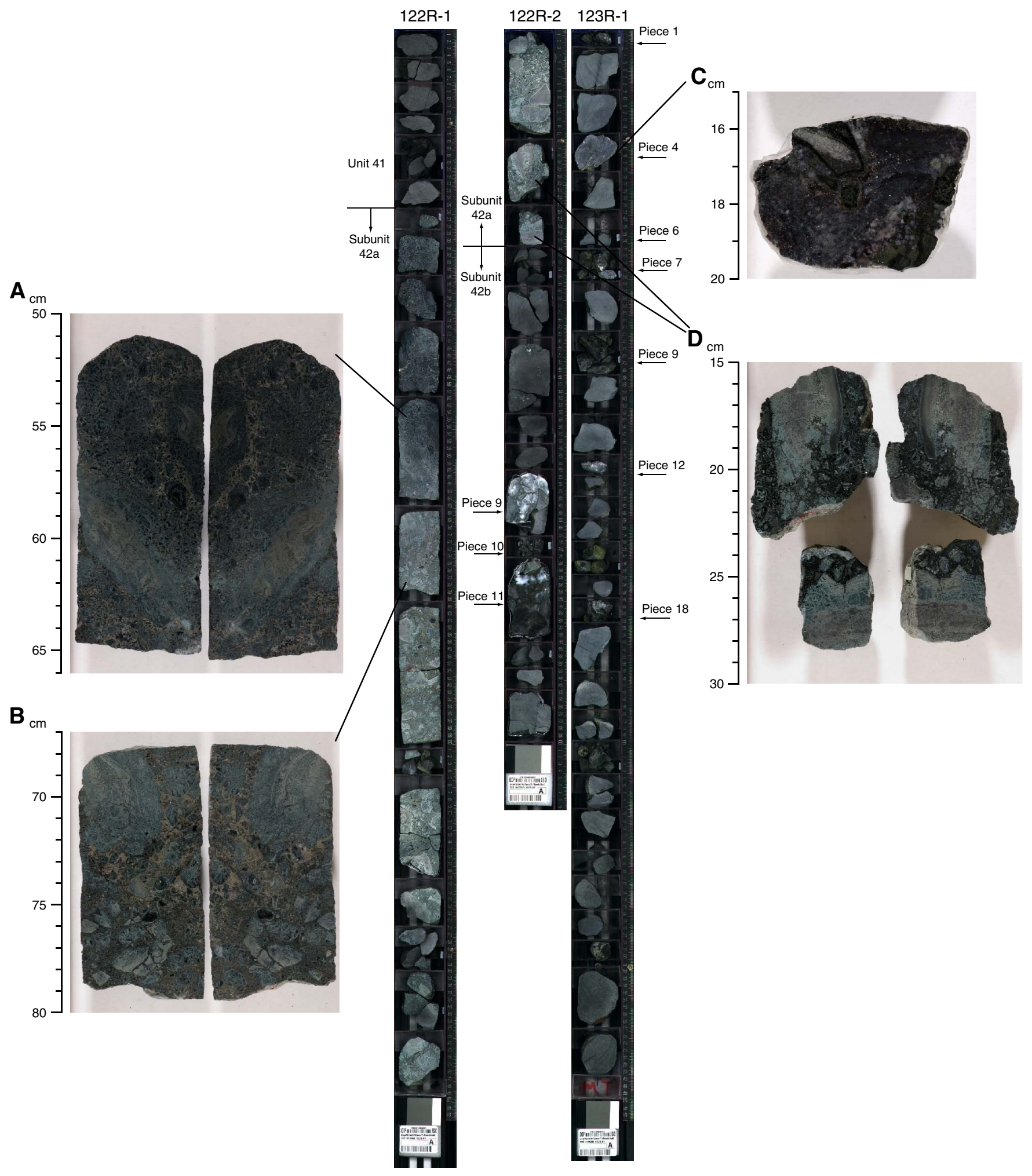


Figure F25. Holocrystalline, intergranular texture in a fine-grained dolerite of massive basalt in sheeted dikes (Thin Section 98; Sample 309-1256D-130R-2, 38-41 cm) (field of view = $2.5 \mathrm{~mm}$ ).

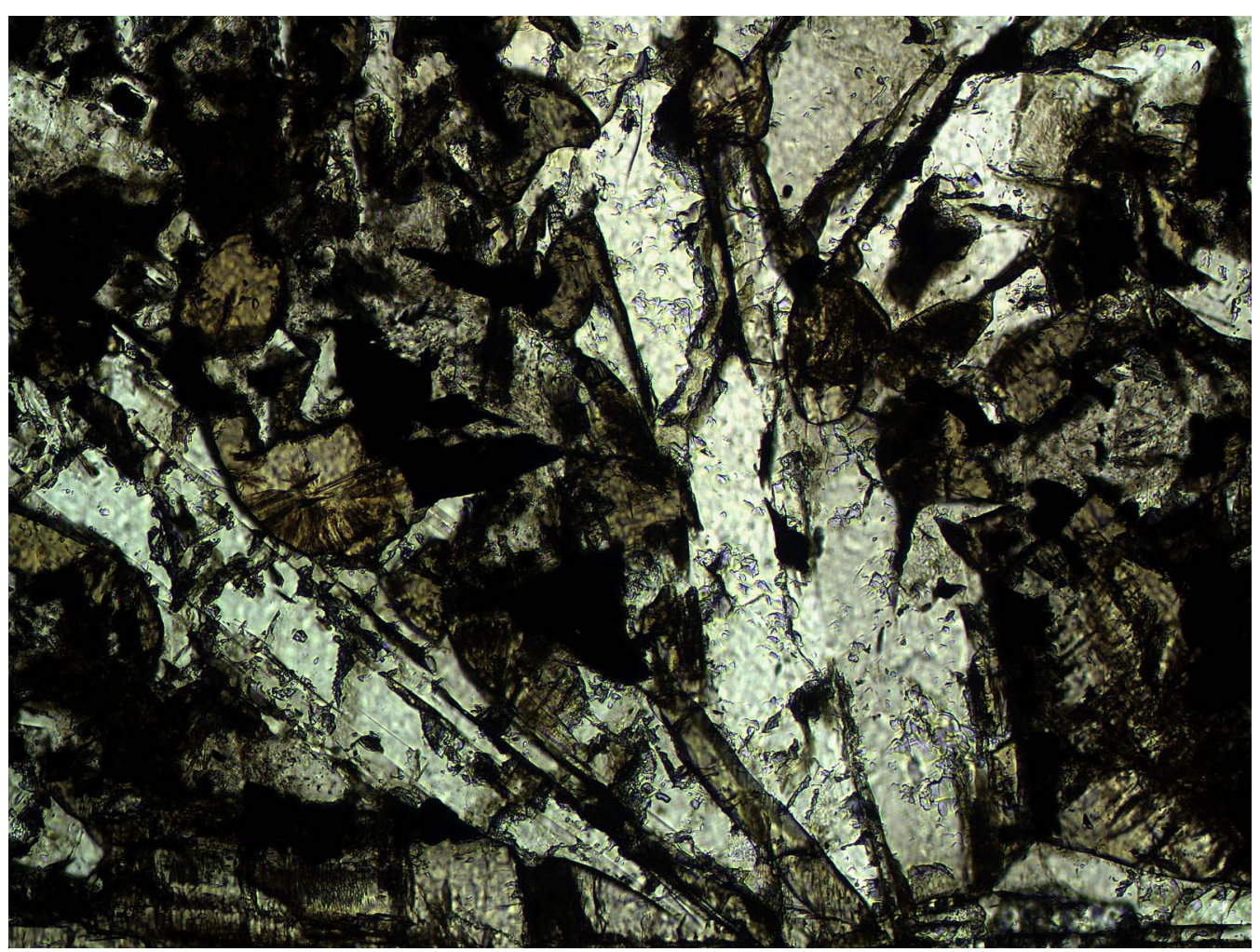


Figure F26. Cryptocrystalline chilled margin of Unit 1256D-69 formed by rapid cooling during intrusion into microcrystalline basalt of Unit 1256D-68 (Thin Section 7; Sample 312-1256D-175R-1, 43-46 cm) (field of view $=30.0 \mathrm{~mm})$.

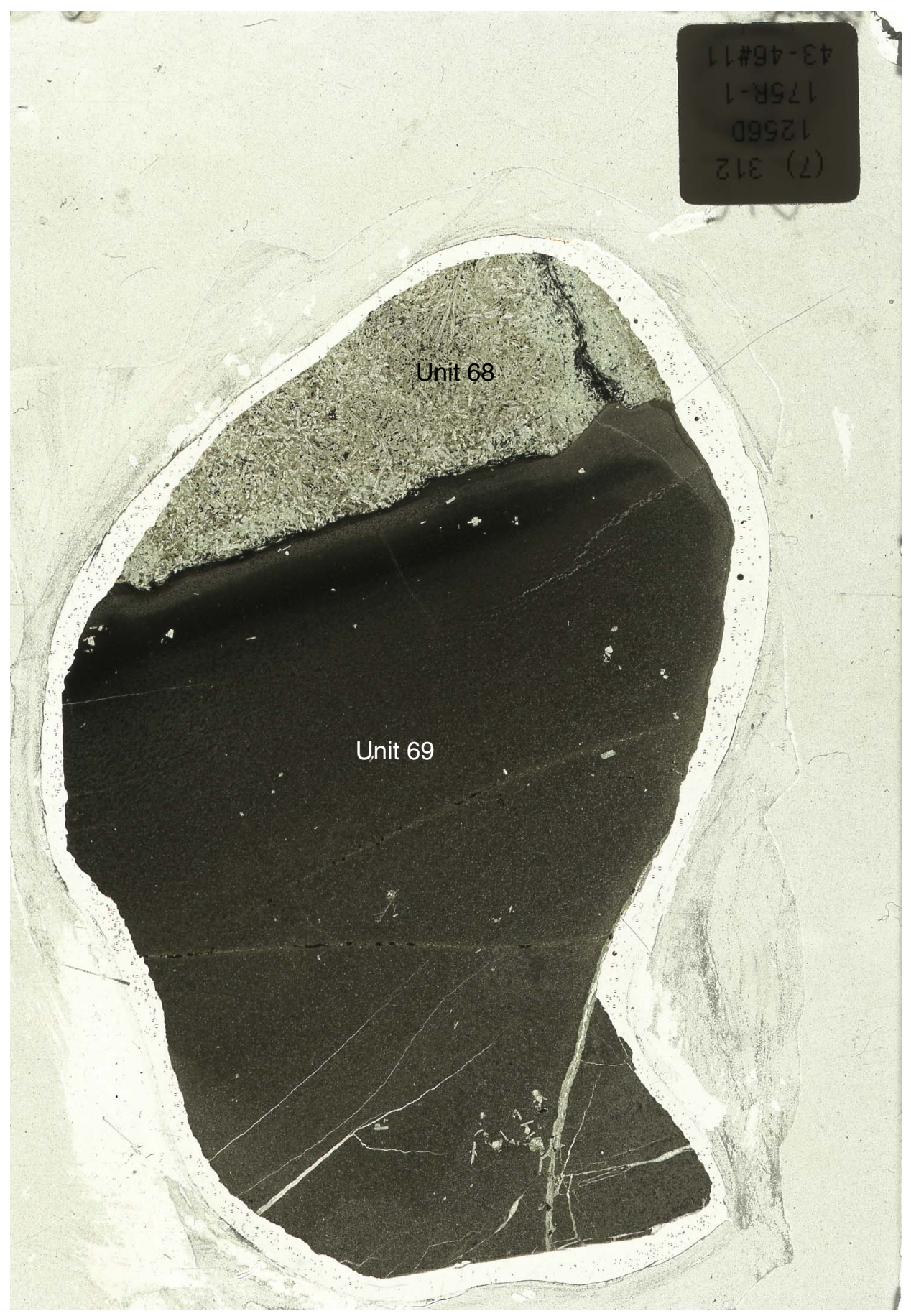


Figure F27. Downhole plot showing the relationship between units (first column), dike subdivisions inferred from lithologic observations, and key geochemical parameters. Cooling units are defined by variations in grain size, from finer at the dike margins to coarser at their centers. Horizontal lines indicate the nature of the unit boundaries, either as recovered intrusive contacts, boundaries defined on the basis of the presence of cryptocrystalline material, or unit boundaries assigned using other criteria. Putative individual dikes, whose extent is determined by matching the observed contact types and cooling units with the minimum number of nonrepeating intrusions (see text) are alternately shaded light blue and white.

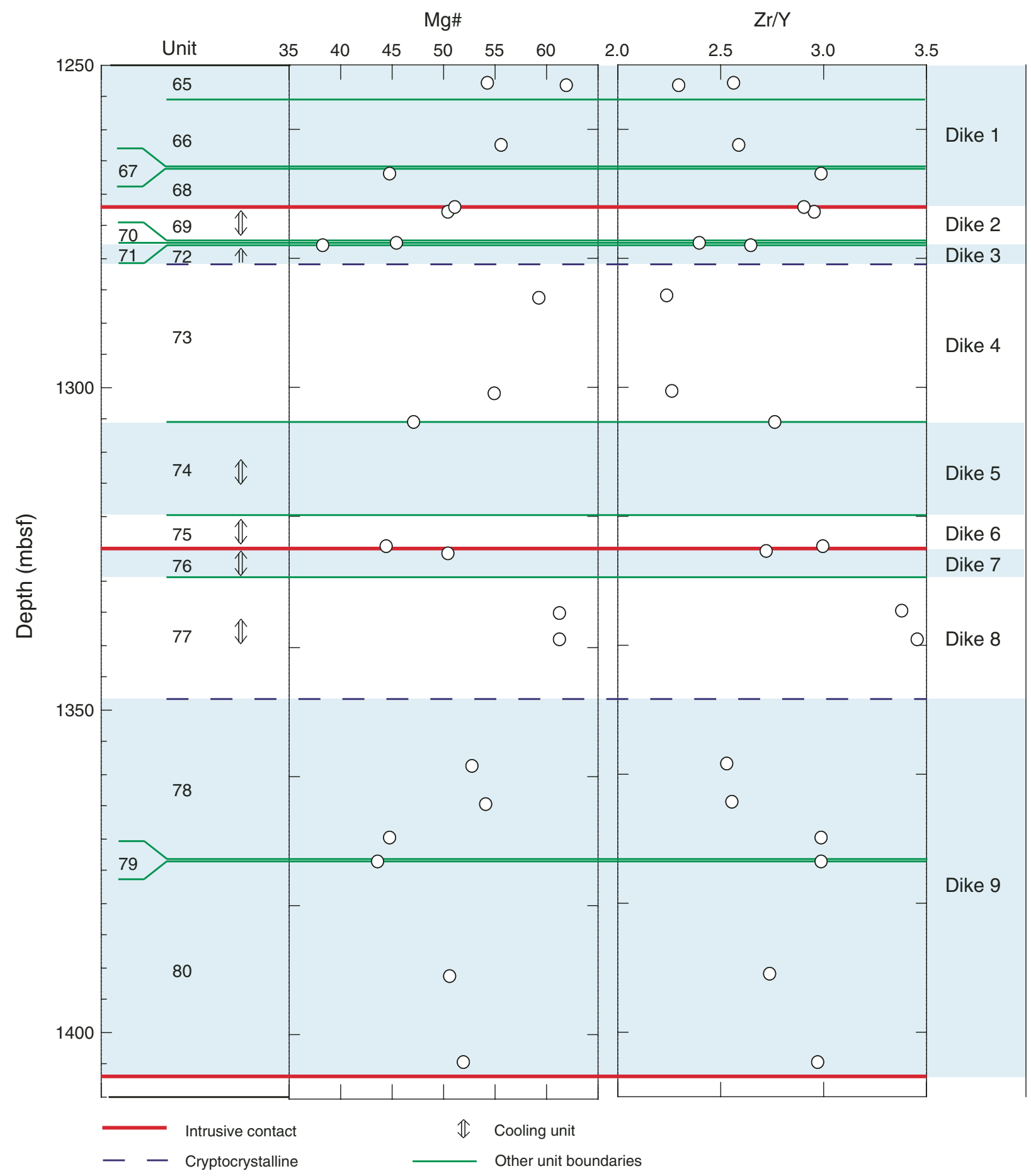


Figure F28. Sulfide-impregnated dike margin breccia (interval 309-1256D-140R-1, $42-58 \mathrm{~cm}$ ).

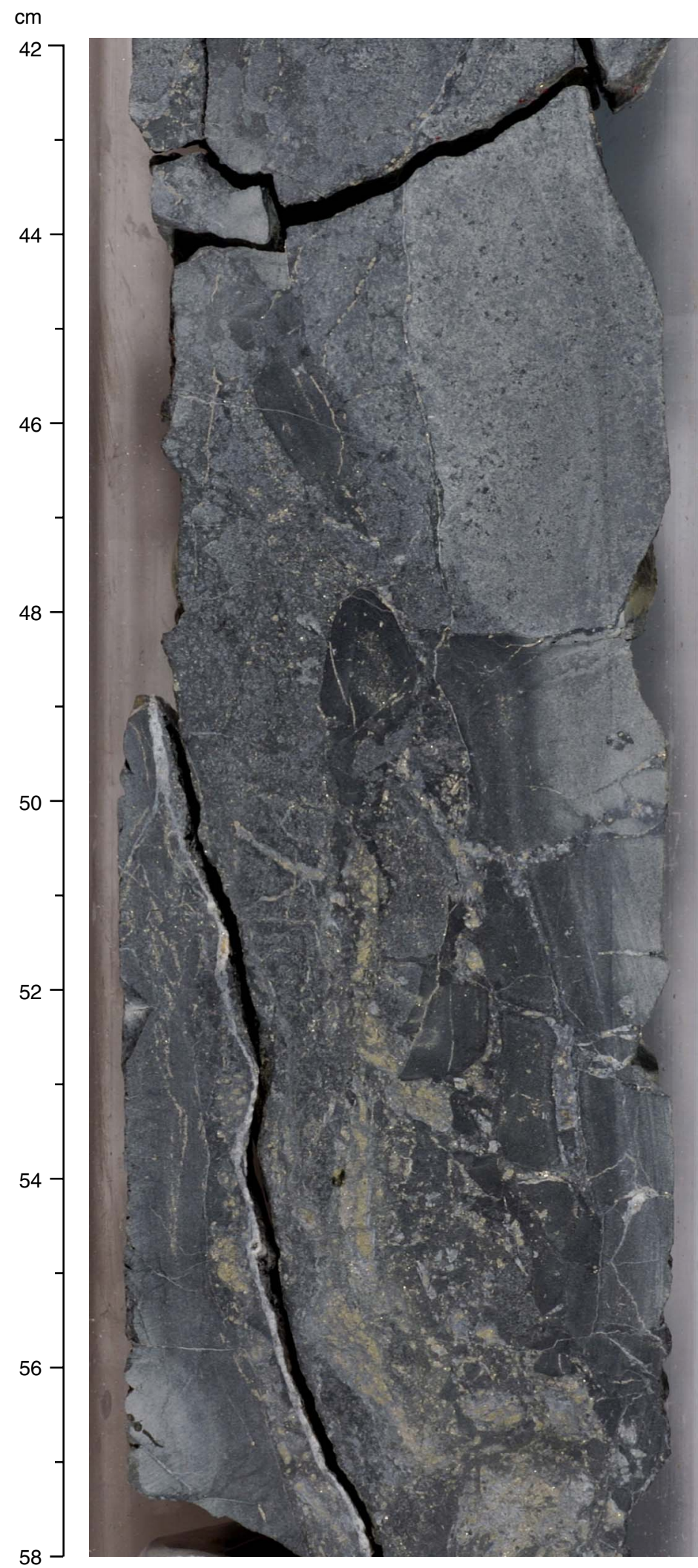


Figure F29. Complex intrusive contacts. A. Composite dike (interval 309-1256D-155R-1, 83-90 cm). The chilled margin forms a convex lobe, indicating that the host rock was still ductile during the intrusion. B. An inner sparsely phyric dike intrudes a sparsely phyric spherulitic chilled margin, which is different from the aphyric host rock (interval 309-1256D-161R-2, 0-8 cm). Therefore, in this piece, two subsequent intrusive contacts are recorded. C. Lobate contact with brecciation of the external chilled margin and dispersion of the small clasts in the host rock observed (interval 309-1256D-163R-1, 112-122 cm).
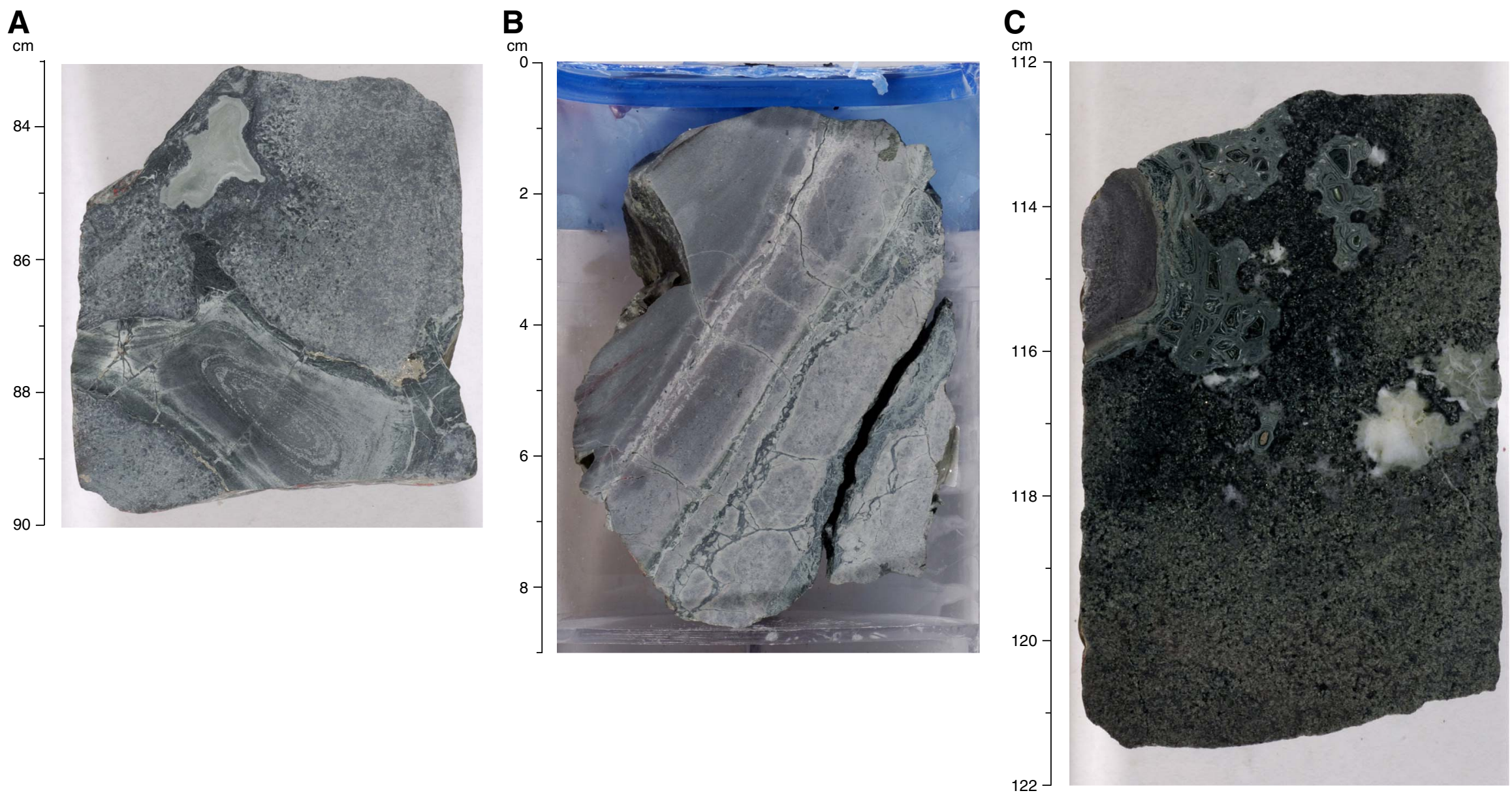

90 
Figure F30. Expedition 309 phenocryst content compared with Leg 206 phenocryst data. A. Frequency of modal abundance of phenocrysts in basalt. B. Proportion of plagioclase-clinopyroxene-olivine phenocrysts in basalt. C. Relative abundance of plagioclase-clinopyroxene-olivine phenocrysts in basalt.

A

Phenocryst content (vol\%)
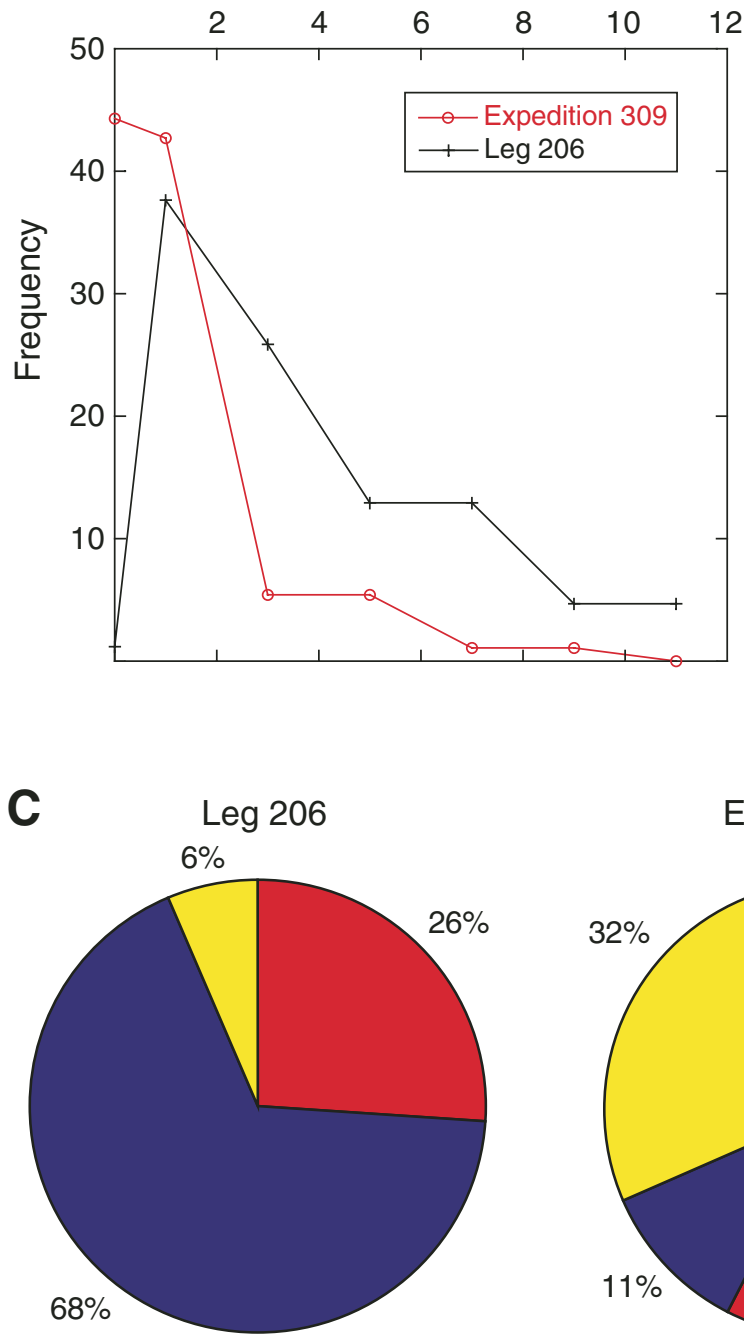

B

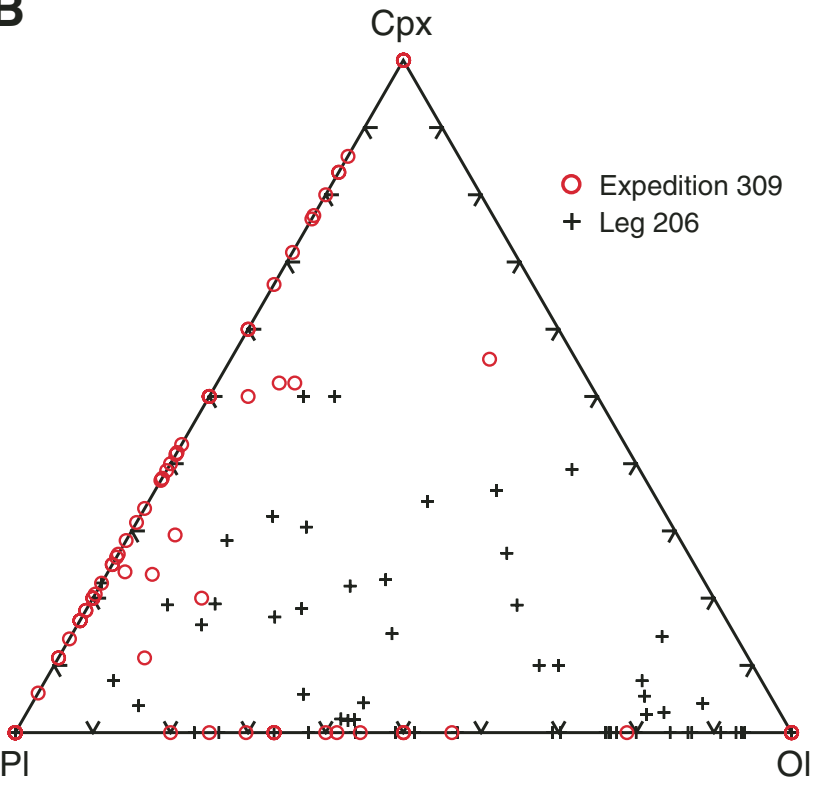

Plagioclase

Olivine

Clinopyroxene 
Figure F31. Dike completely recrystallized to a granoblastic association of equant secondary plagioclase, clinopyroxene, and magnetite (Thin Section 49; Sample 312-1256D-205R-1, 10-14 cm) (field of view = $0.6 \mathrm{~mm}$; plane-polarized light).

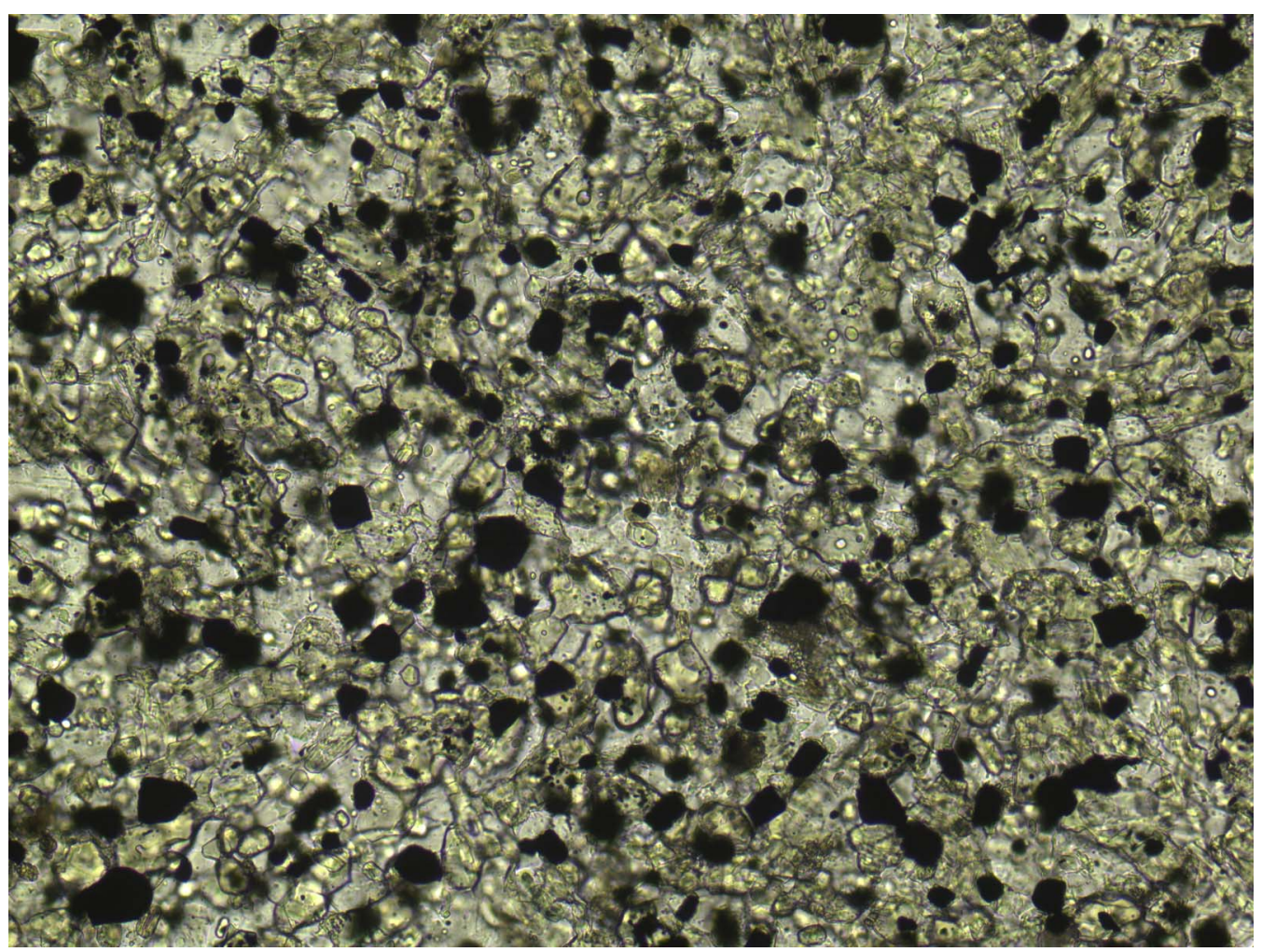


Figure F32. Typical sample from Gabbro 1, which is characterized by two domains that are present to varying extents throughout: clinopyroxene oikocrysts with small plagioclase chadacrysts form subophitic "dark domains" that appear as subspherical dark patches in hand specimen and coarser grained "network domains" between oikocrysts that are characterized by coarser grain size, zoned prismatic plagioclase, and abundant oxides. They appear as a network of lighter colored material in hand specimen (Thin Section 63; Sample 3121256D-214R-2, 0-6 cm). A. Plane-polarized light. B. Cross-polarized light.
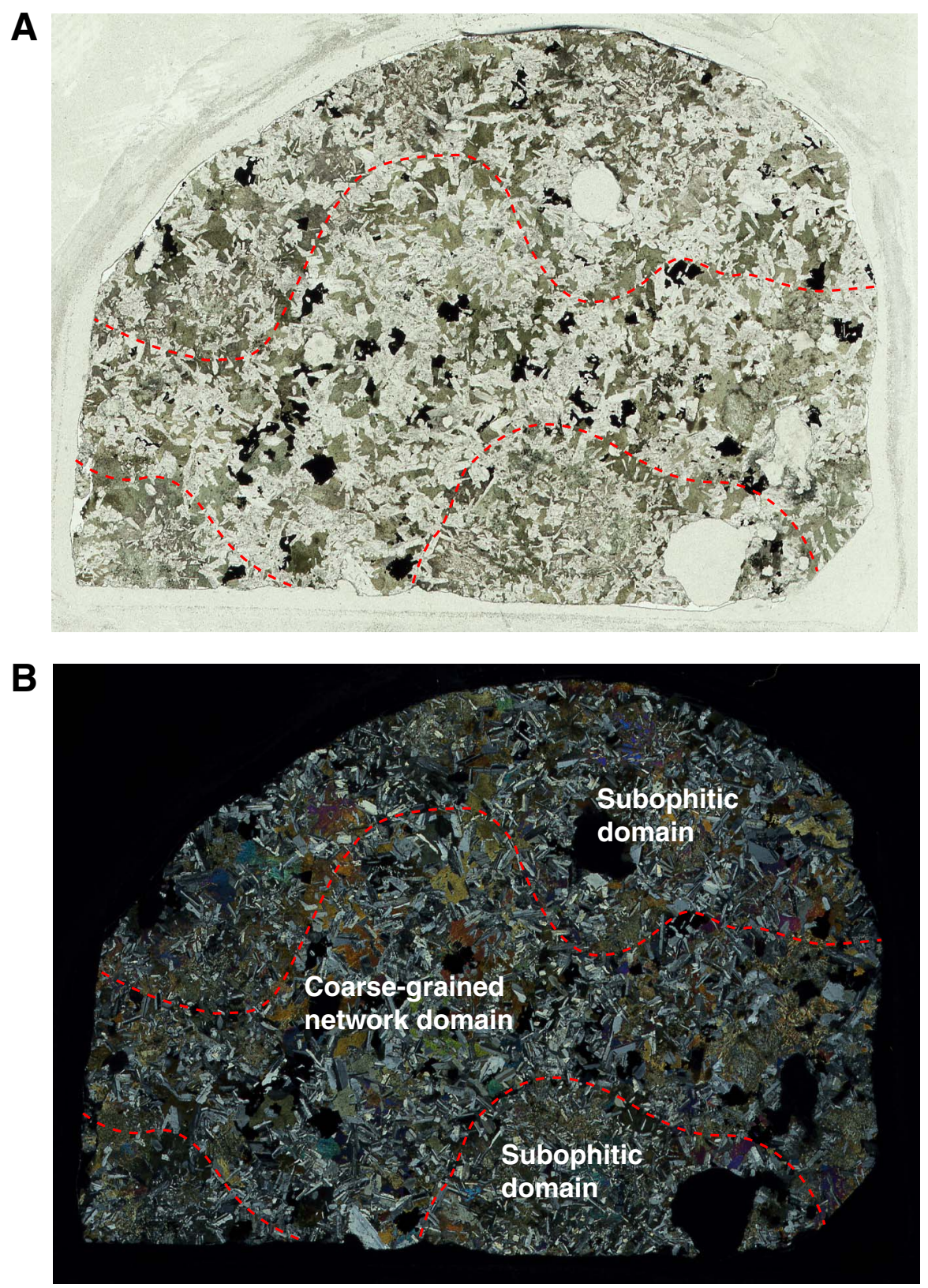
Figure F33. A. Large orthopyroxene (opx) oikocryst containing tiny inclusions of granular clinopyroxene, typical for Gabbro 2 (Unit 1256D-91) (Thin Section 110; Sample 312-1256D-230R-1, 36-40 cm) (field of view $[\mathrm{FOV}]=0.6 \mathrm{~mm}$; plane- and cross-polarized light). Note abundant dusty spots in plagioclase (plag) suggest that these grains are secondary, incorporating earlier altered material. B. Poikilitic orthopyroxene containing small blebs of clinopyroxene in orthopyroxene-bearing gabbro (Unit 1256D-92), the central, orthopyroxenebearing part of Gabbro 2 (Thin Section 113; Sample 312-1256D-232R-1, 97-100 cm) (FOV = $2.4 \mathrm{~mm}$; planeand cross-polarized light).
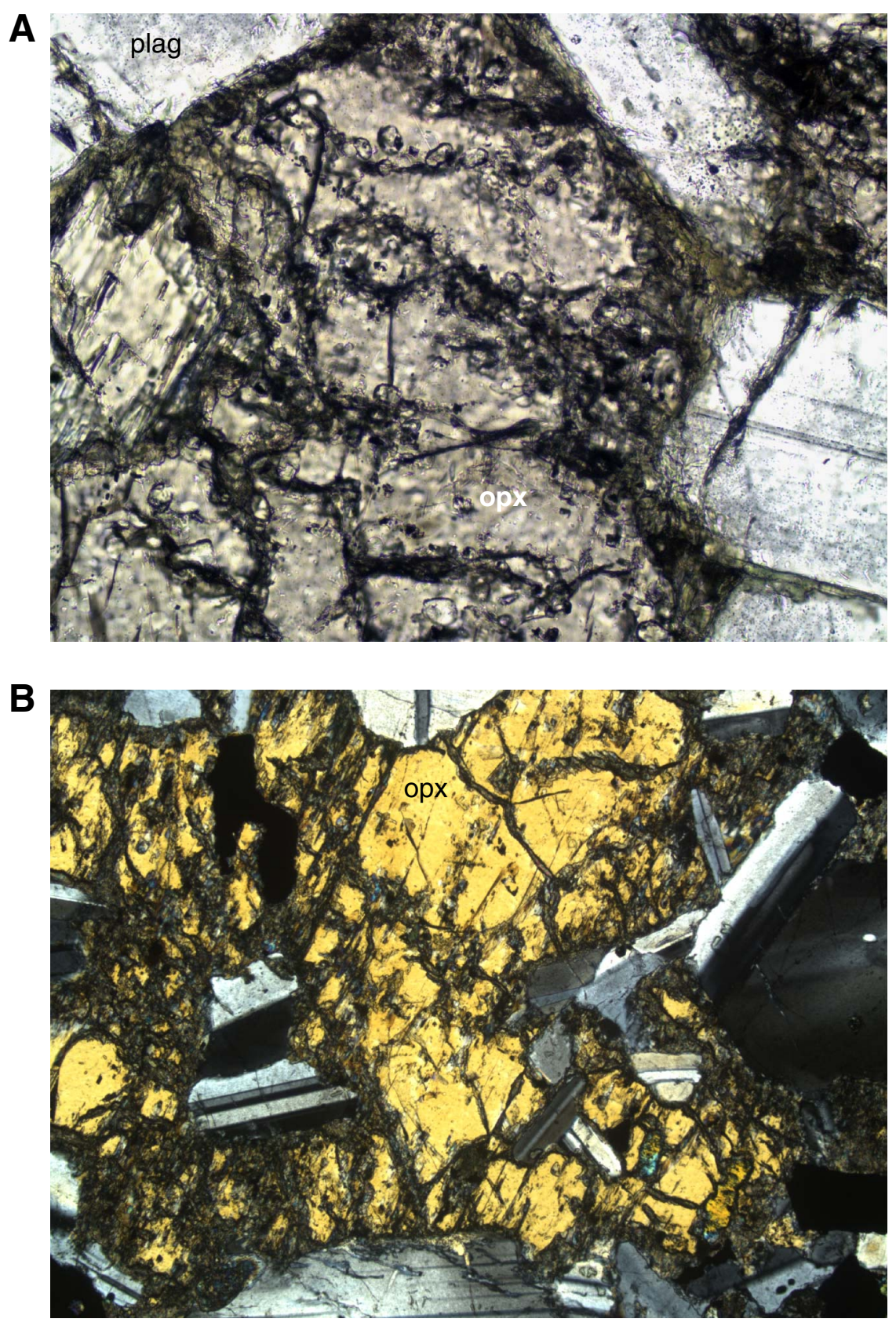
Figure F34. Whole round of contact between Unit 1256D-90a (basalt dike) and Unit 1256D-91 (gabbro margin). The pink color of the contact-metamorphosed basalt is caused by orthopyroxene. This basalt is invaded and pieces detached by the intruding gabbronorite of uppermost Gabbro 2 in Piece 5, 15-24 cm (interval 3121256D-230R-1, 15-33 cm).

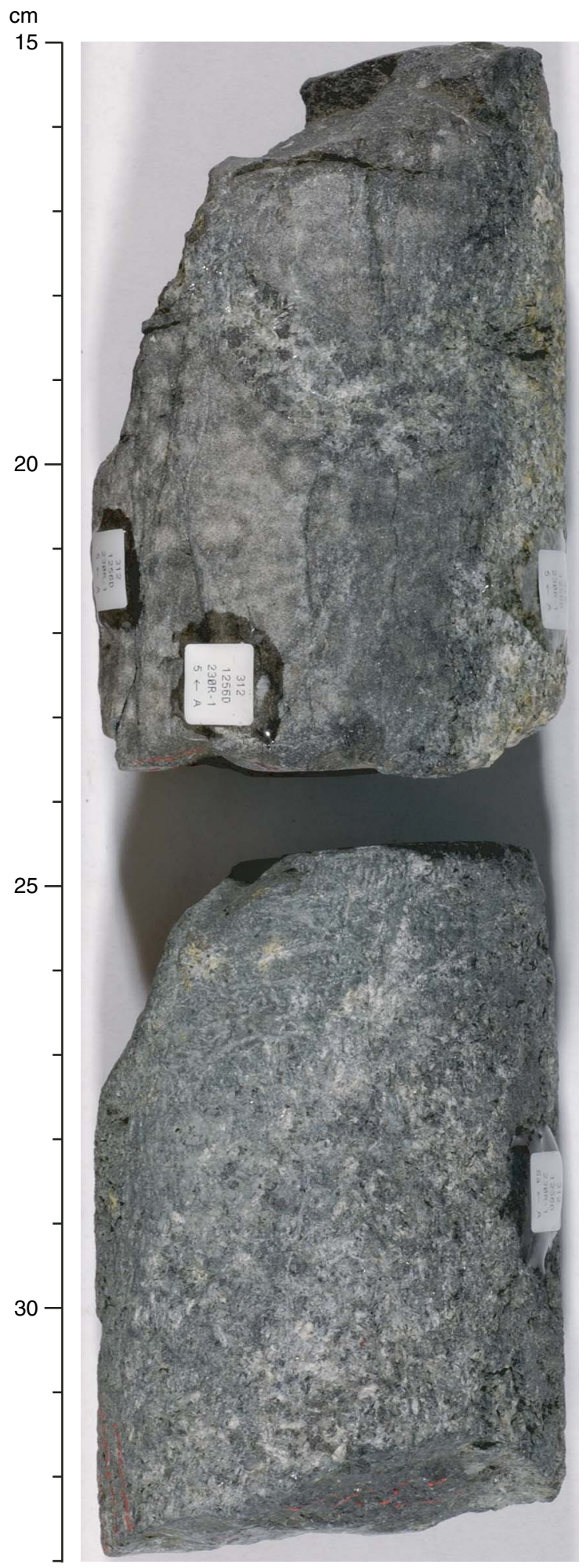


Figure F35. Plots of whole-rock chemical composition (shipboard ICP-AES analyses) with igneous stratigraphy and units. Error bar indicates analytical precision. $\mathrm{LP}=$ lava pond, $\mathrm{SF}=$ sheet flow, $\mathrm{MB}=$ massive basalt, $\mathrm{BD}=$ basalt dike, $\mathrm{G}=$ gabbro, $\mathrm{QOD}=$ quartz oxide diorite, $\mathrm{TD}=$ trondjhemite. (Continued on next four pages.)

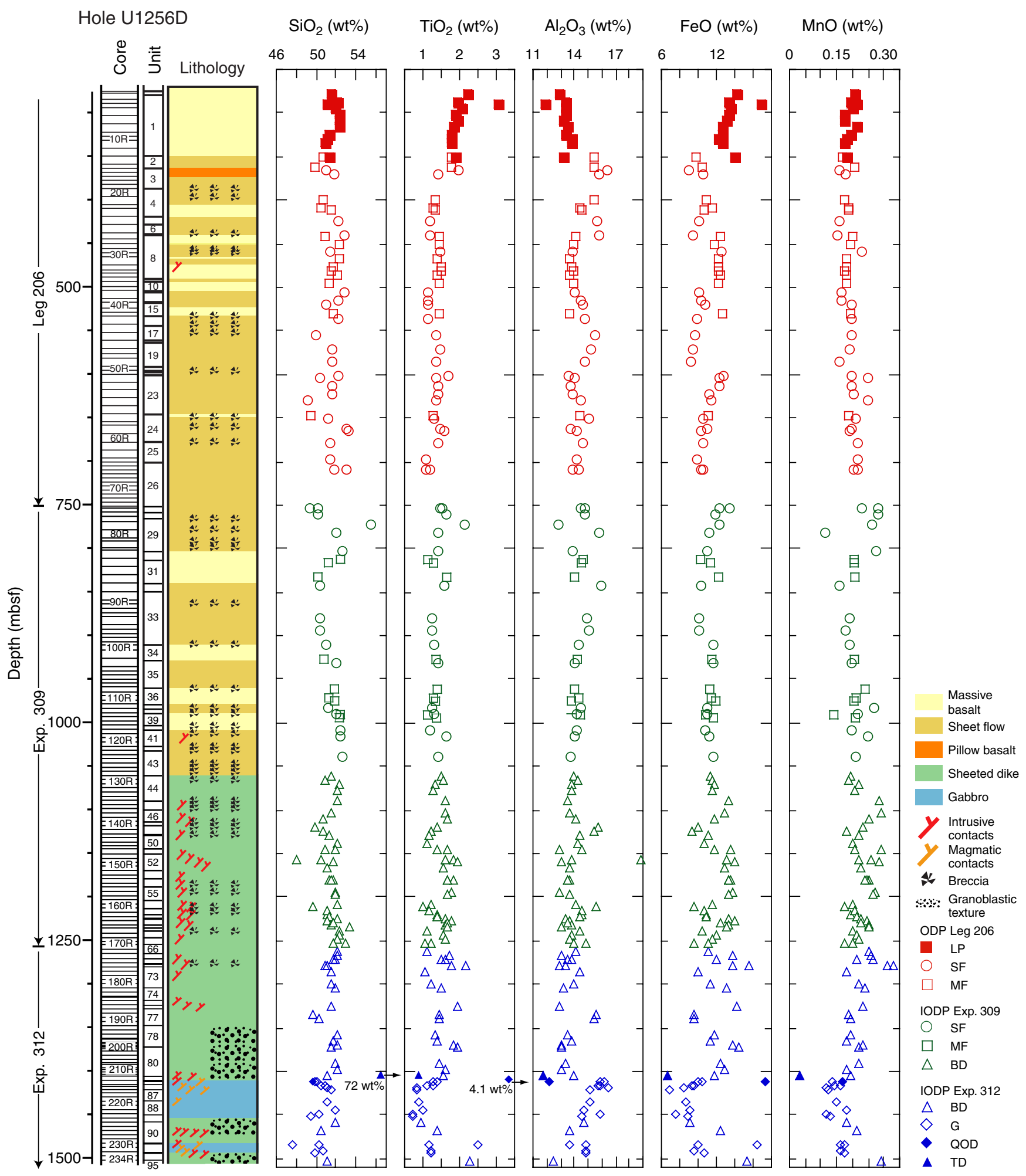


Figure F35 (continued). Plots of whole-rock chemical composition. (Continued on next page.)

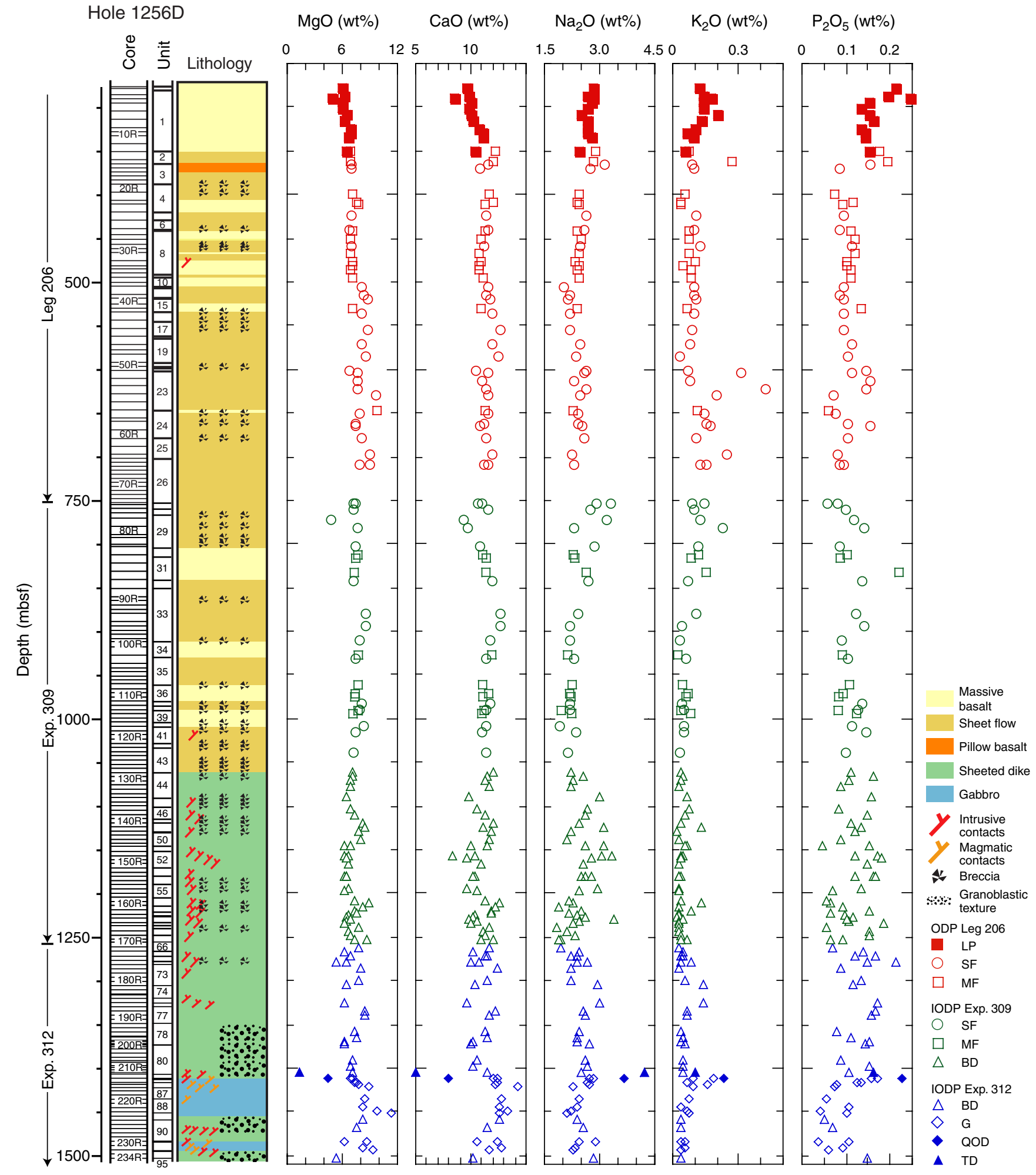


Figure F35 (continued). Plots of whole-rock chemical composition. (Continued on next page.)

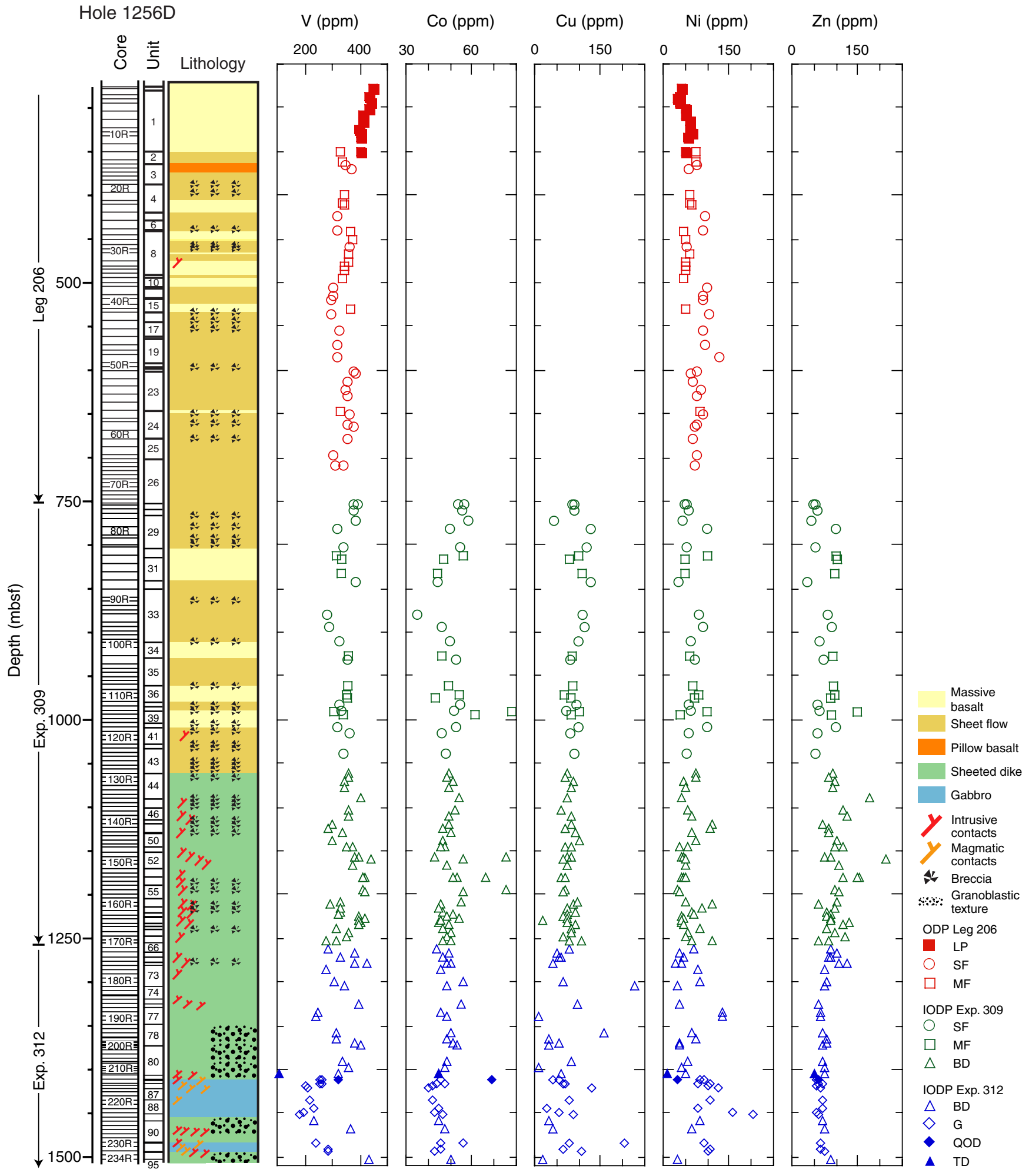


Figure F35 (continued). Plots of whole-rock chemical composition. (Continued on next page.)

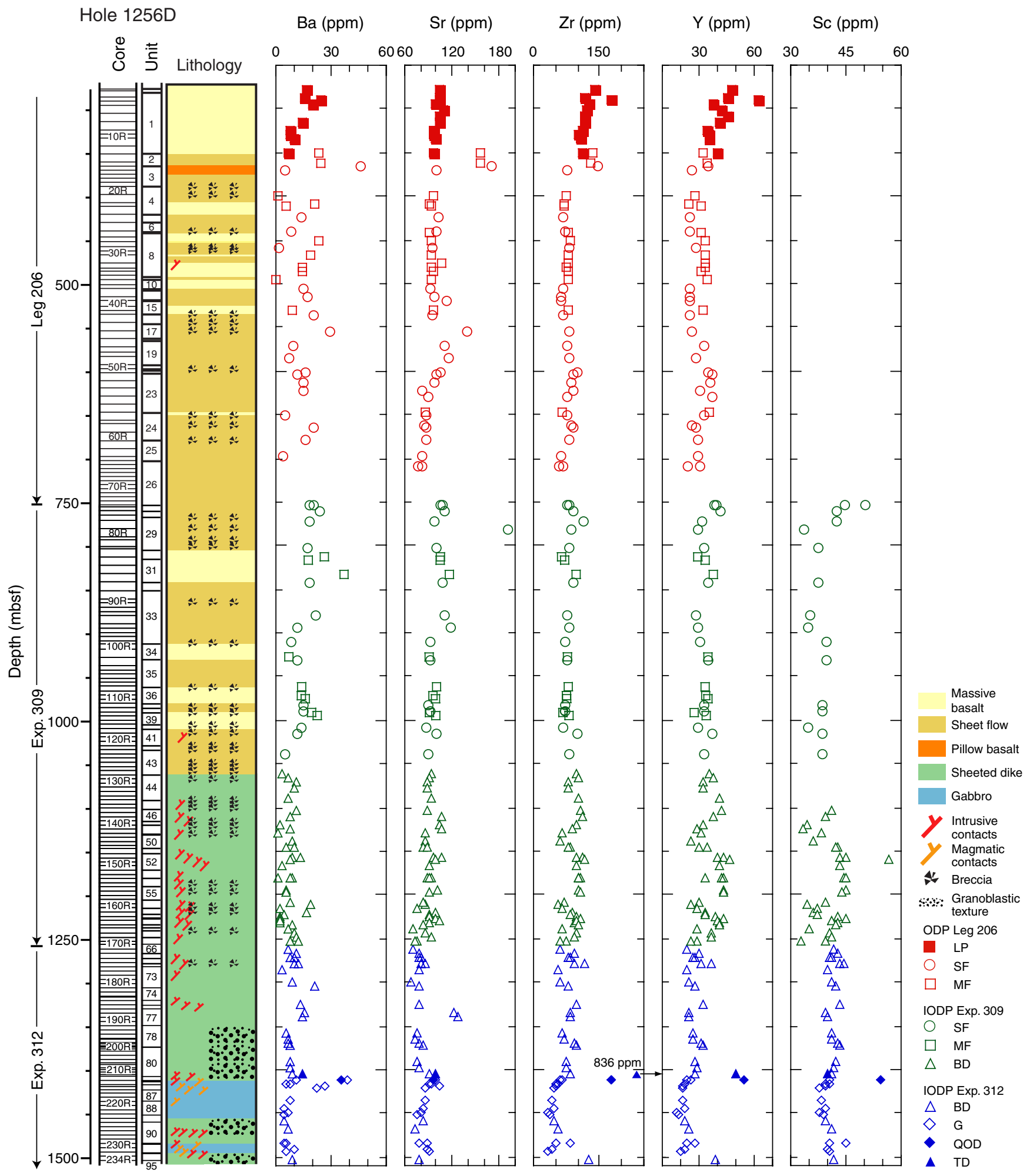


Figure F35 (continued). Plots of whole-rock chemical composition.

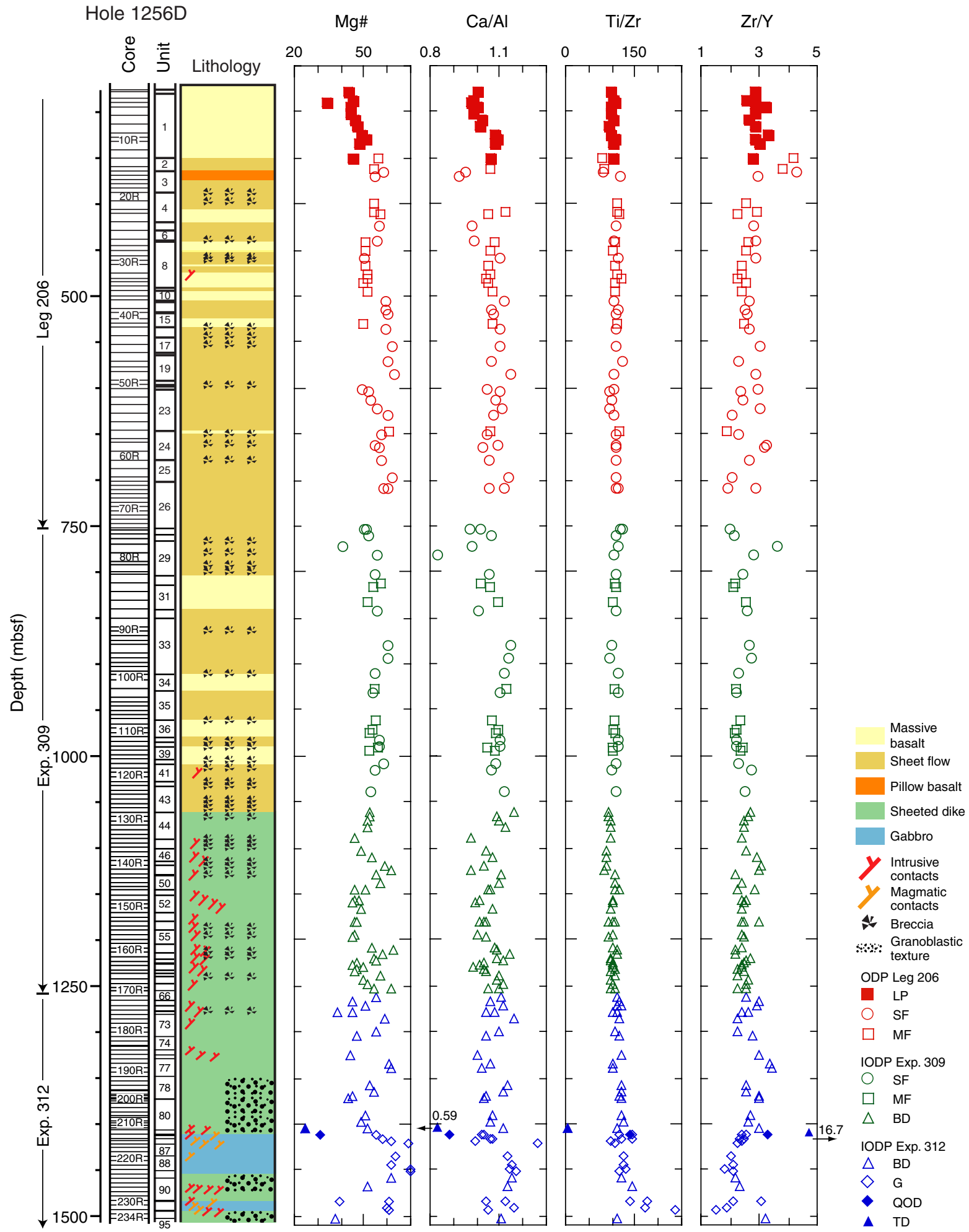


Figure F36. Plots of all elements vs. $\mathrm{MgO}$ for all whole-rock shipboard analyses. Error bar indicates analytical precision. $\mathrm{LP}=$ lava pond, $\mathrm{SF}=$ sheet flow, $\mathrm{MB}=$ massive basalt, $\mathrm{BD}=$ basalt dike, $\mathrm{G}=$ gabbro, $\mathrm{QOD}=$ quartz oxide diorite, $\mathrm{TD}=$ trondjhemite, $\mathrm{GC}=$ ghost core. (Continued on next page.)
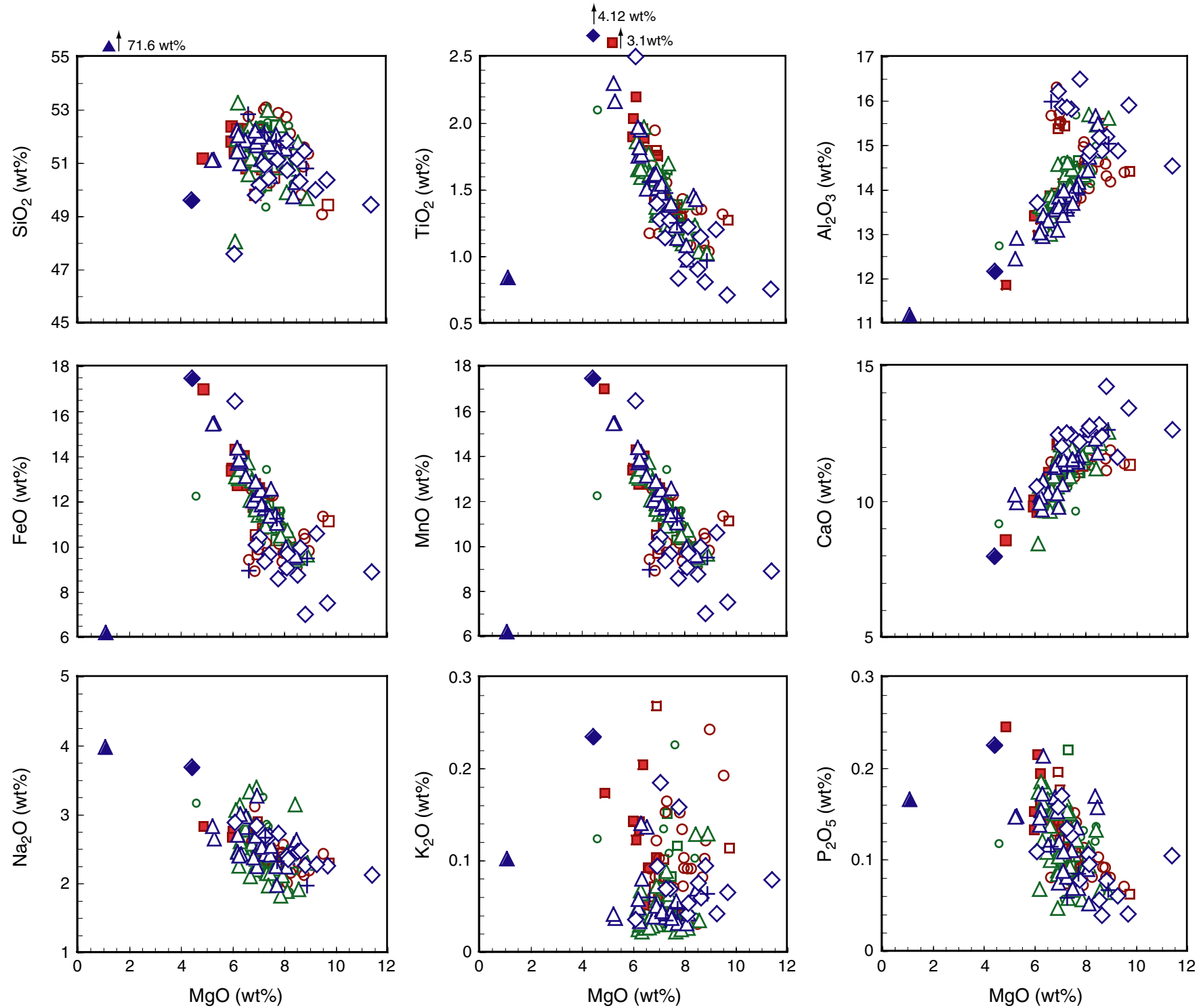

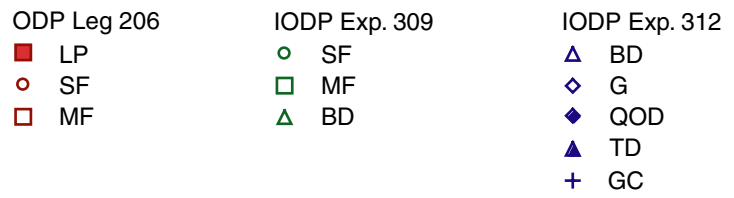


Figure F36 (continued). Plots of all elements vs. MgO.
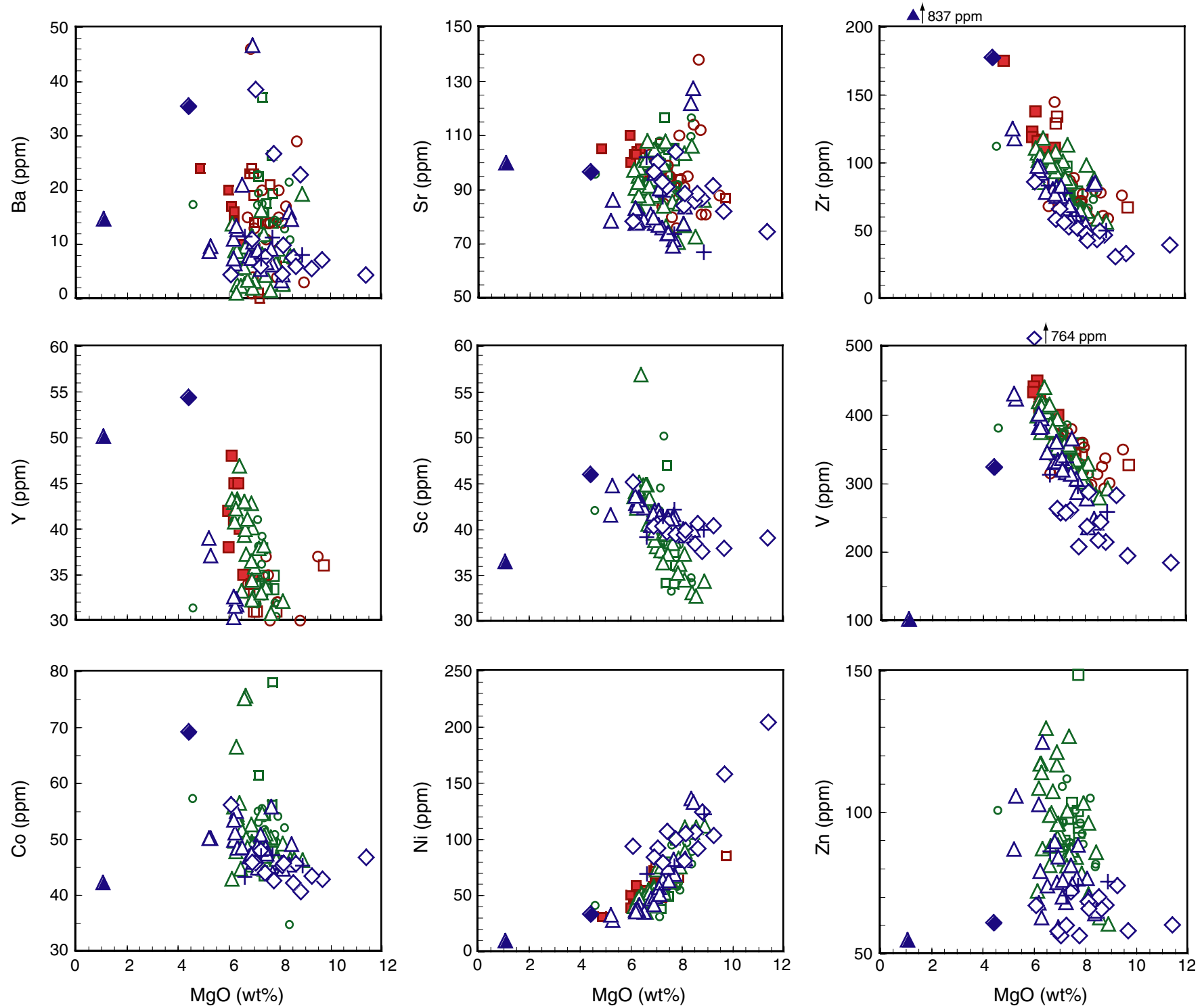

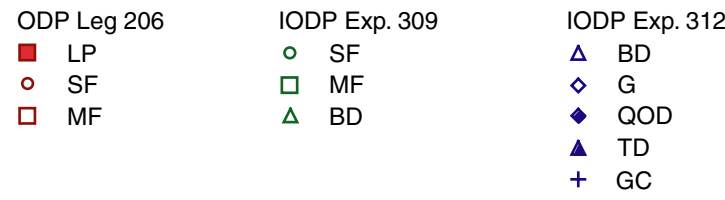


Figure F37. Sc/Y vs. Sr/Y. EPR = East Pacific Rise. $\mathrm{LP}=$ lava pond, $\mathrm{SF}=$ sheet flow, $\mathrm{MB}=$ massive basalt, $\mathrm{BD}=$ basalt dike, $\mathrm{G}=$ gabbro, $\mathrm{QOD}=$ quartz oxide diorite, $\mathrm{TD}=$ trondjhemite, $\mathrm{GC}=$ ghost core .

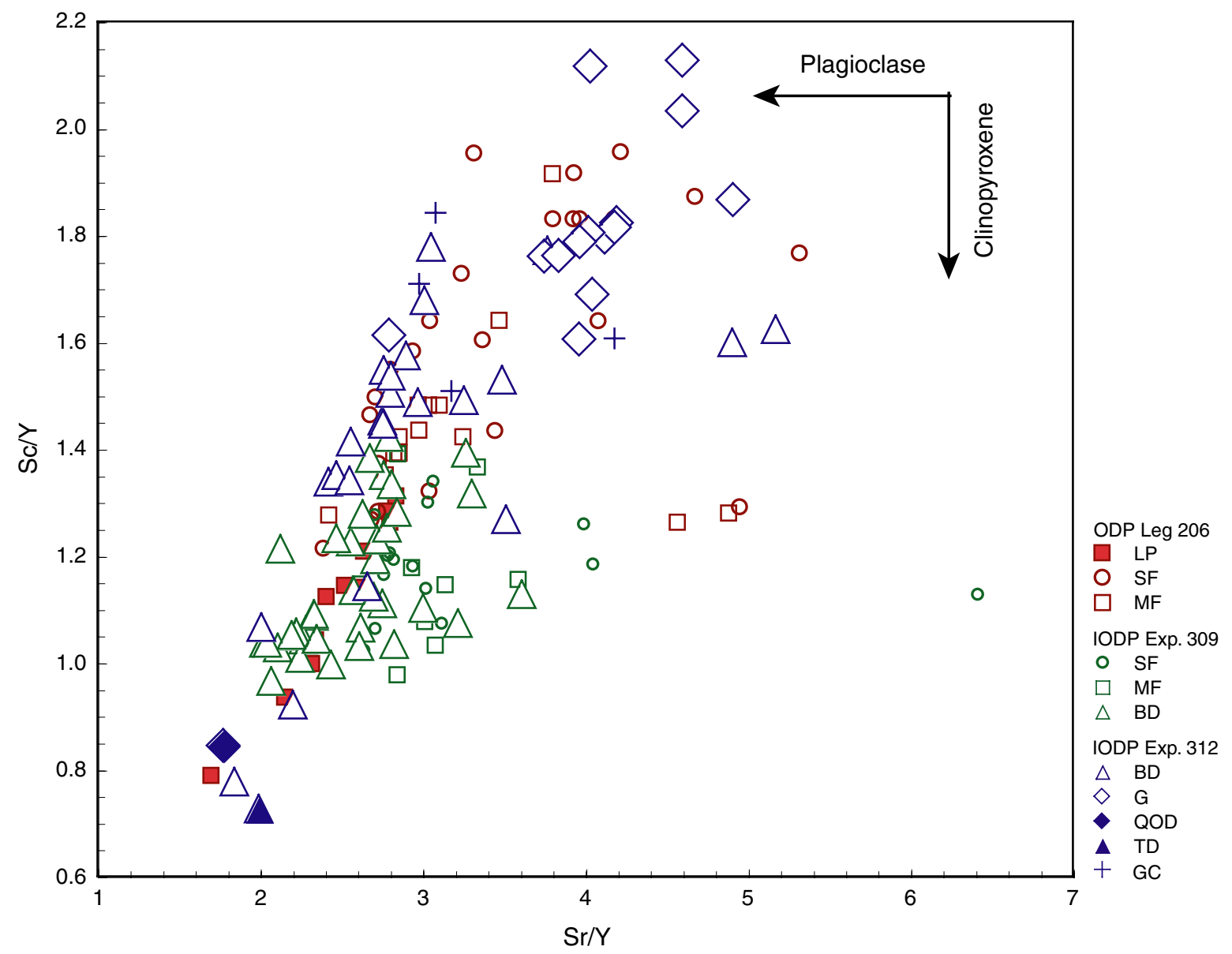


Figure F38. $\mathrm{Zr}$ vs. $\mathrm{Y}$ and $\mathrm{Zr}$ vs. Ti for basalts from Site 1256. $\mathrm{LP}=$ lava pond, $\mathrm{SF}=$ sheet flow, $\mathrm{MB}=$ massive basalt, $\mathrm{BD}=$ basalt dike, $\mathrm{G}=$ gabbro, $\mathrm{QOD}=$ quartz oxide diorite, $\mathrm{TD}=$ trondjhemite, $\mathrm{GC}=$ ghost core.
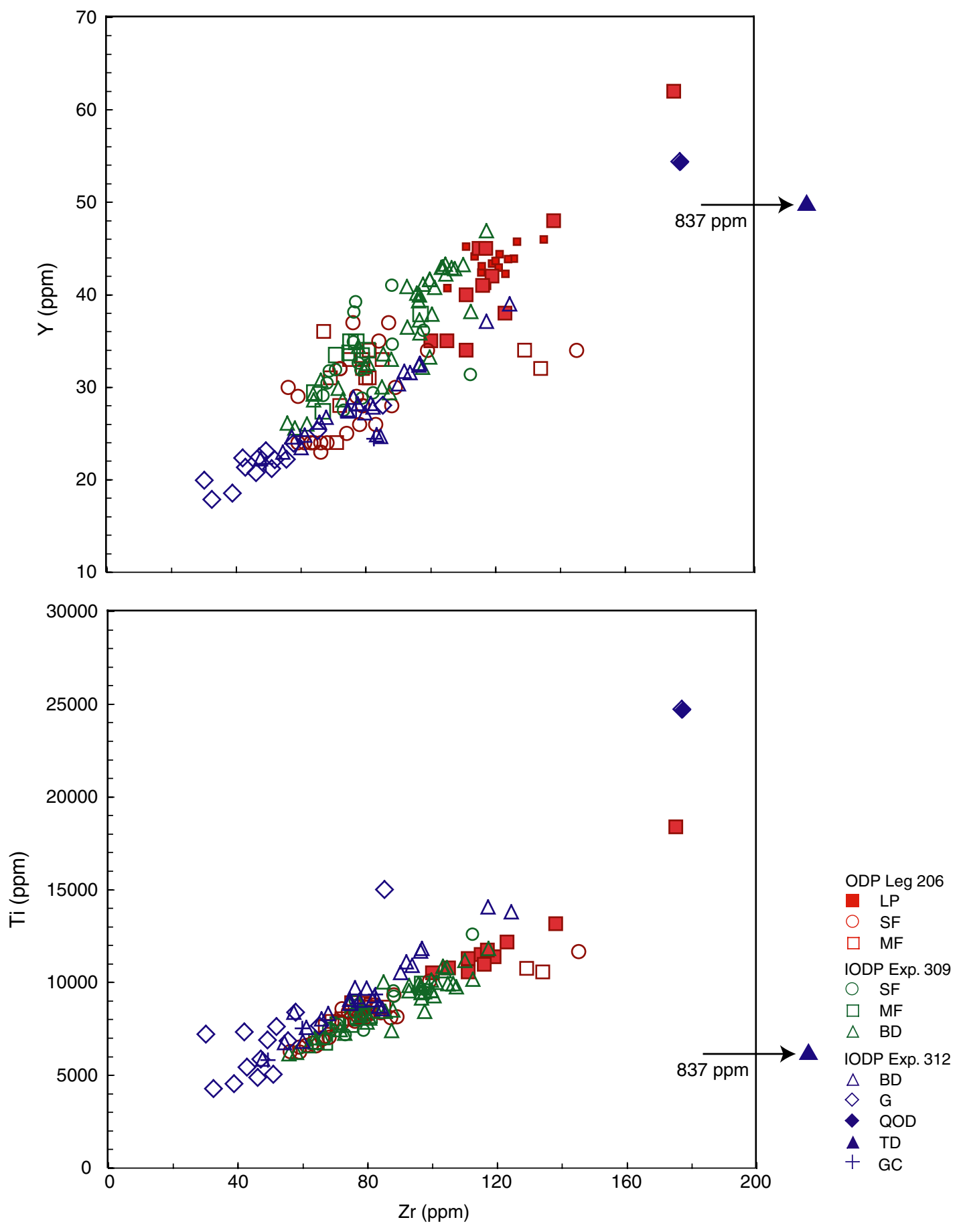
Figure F39. East Pacific Rise (EPR) mid-ocean-ridge basalt (MORB)-normalized multielement plot of the average of different lithologic subdivisions from Hole 1256D. LP = lava pond, $\mathrm{MF}=$ massive flow, $\mathrm{SF}=$ sheet flow, $\mathrm{BD}=$ basalt dike, $\mathrm{G} 1=$ Gabbro 1, G2 = Gabbro 2. The values of $\mathrm{Ba}, \mathrm{Y}, \mathrm{Sr}, \mathrm{Zr}$, and $\mathrm{TiO}_{2}$ are taken from Su and Langmuir et al. (2003). Other elements are compiled from PETDB (www.petdb.org) for basalts with $\mathrm{MgO}>6.0$ wt $\%$.

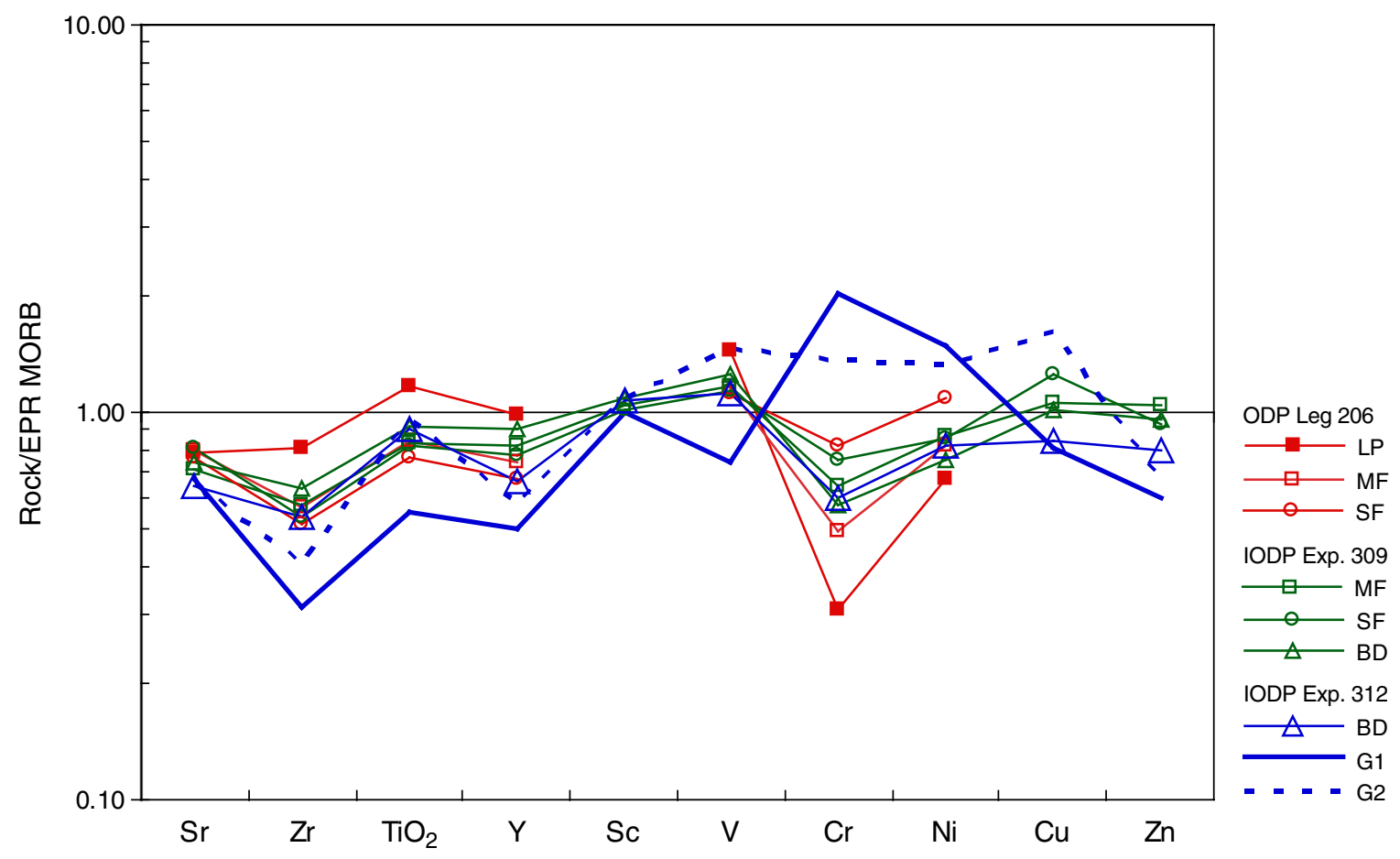


Figure F40. Comparison of incompatible element ratio ( $\mathrm{Ti} / \mathrm{Zr}$ and $\mathrm{Zr} / \mathrm{Y})$ vs. $\mathrm{MgO}$ and basalt from Hole 504B. $\mathrm{EPR}=$ East Pacific Rise. $\mathrm{LP}=$ lava pond, $\mathrm{SF}=$ sheet flow, $\mathrm{MB}=$ massive basalt, $\mathrm{BD}=$ basalt dike, $\mathrm{GC}=$ ghost core. Hole 504B basalts from Autio and Rhodes (1983), Kempton et al. (1985), Natland et al. (1983), Expedition 304 Scientists (2005), and Expedition 305 Scientists (2005).
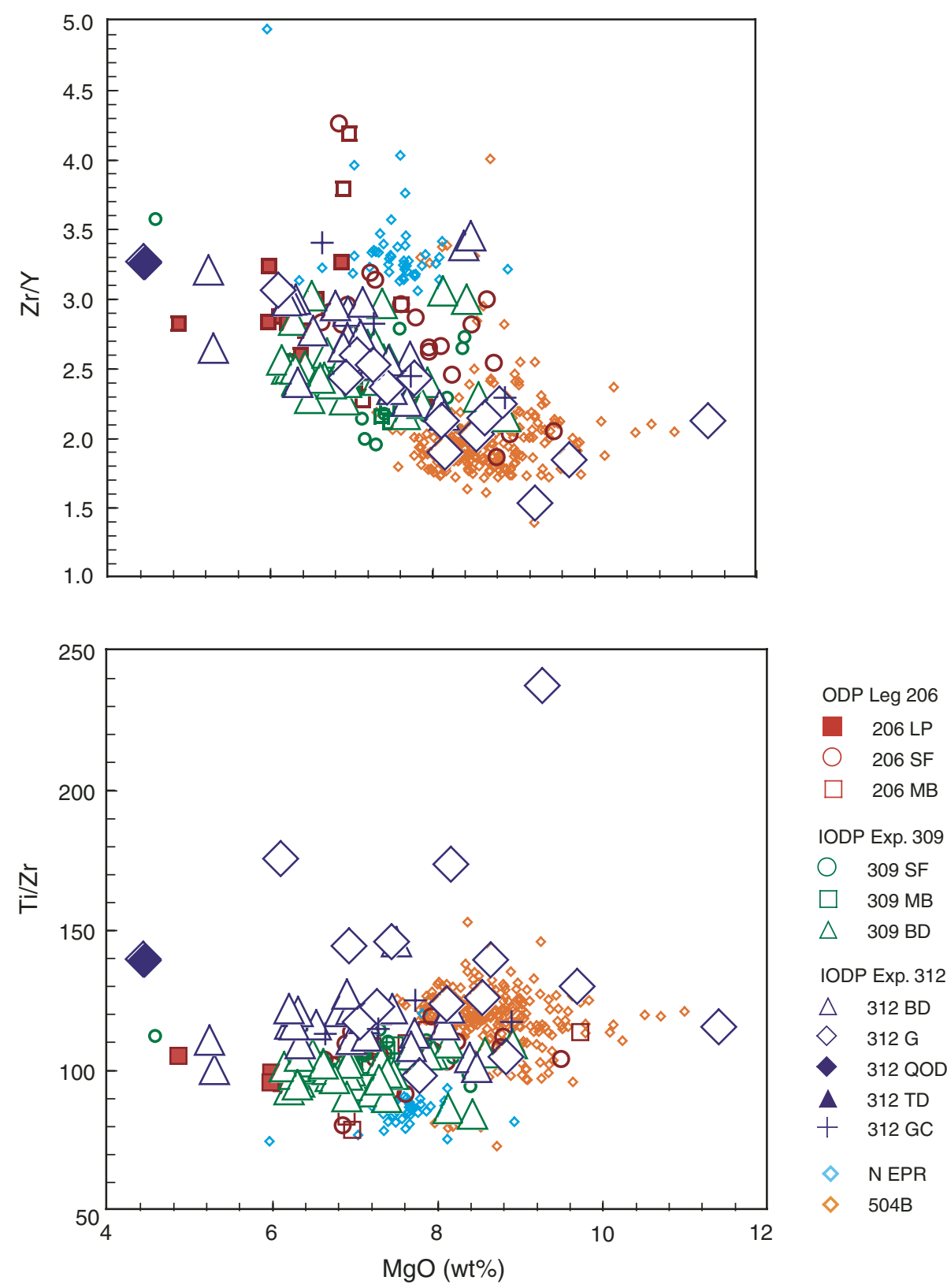
Figure $\mathbf{F 4 1 . ~} \mathrm{Zr} / \mathrm{TiO}_{2}$ and $\mathrm{Zr} / \mathrm{Y}$ ratios for first order mid-ocean-ridge segments along the EPR from $14^{\circ} \mathrm{N}$ to $19^{\circ} \mathrm{S}$ and ODP/IODP Site 1256 (Leg 206 and Expedition 309/312). Zr and Y data are taken from PETDB (www.petdb.org) and the plotted values are the average of segment centers; error bars $=1 \sigma$. The spreading rate of each segment is calculated by the Online Ridge Spreading rate calculator (www.ldeo.columbia.edu/ users/menke/plates.html). The spreading rate of Site 1256 is given by Wilson (1996). The range of latitude of each segment center is indicated by the labels underneath the $\mathrm{x}$-axis, and numbers above the $\mathrm{x}$-axis are the spreading rate (full rate) of each segment.
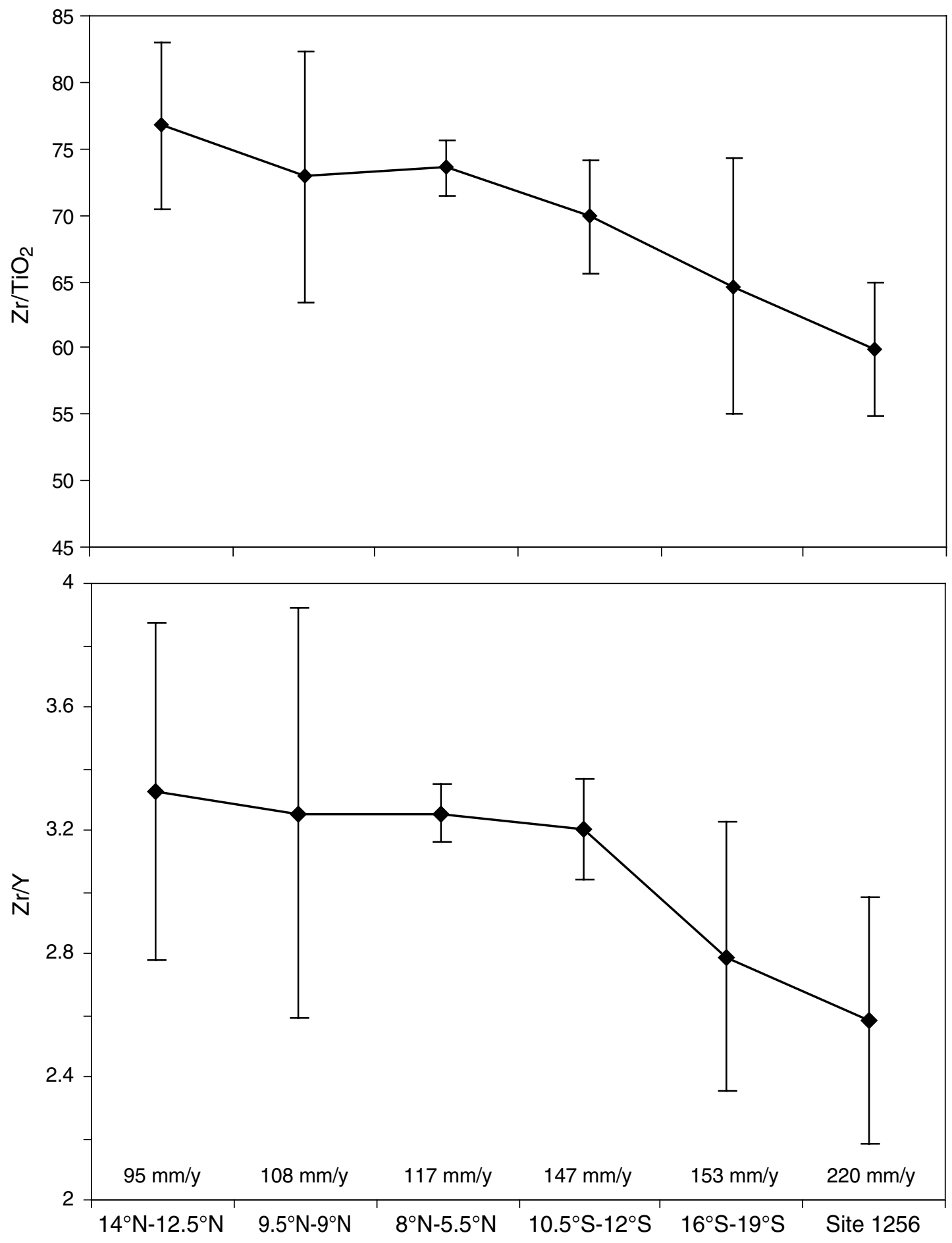
Figure F42. Alteration style and intensity (given as percentage per core) in Hole 1256D. Percentages are normalized to amount of recovered material per core (per meter) and plotted vs. depth to top of core. (This figure is also available in an oversized format.)

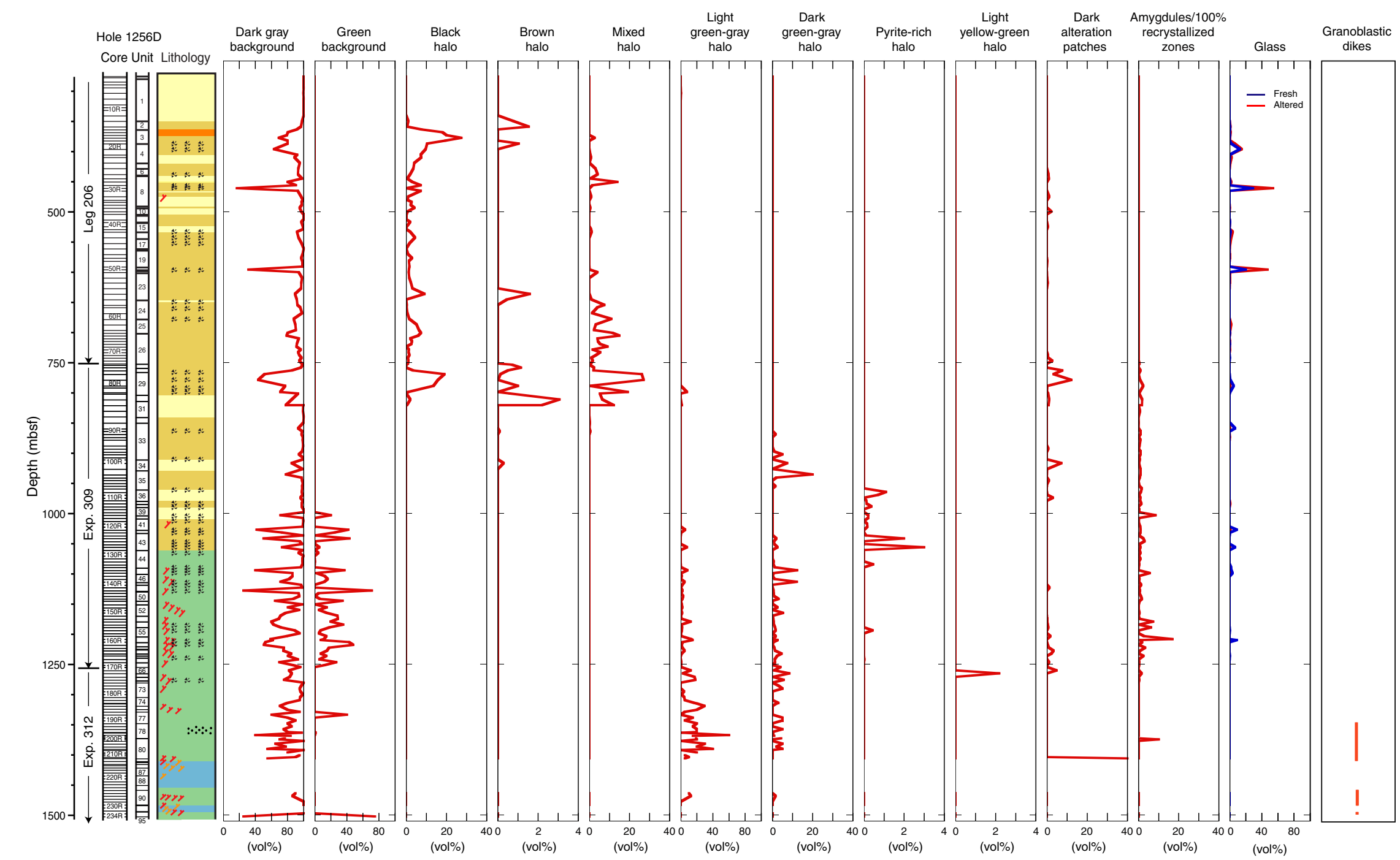



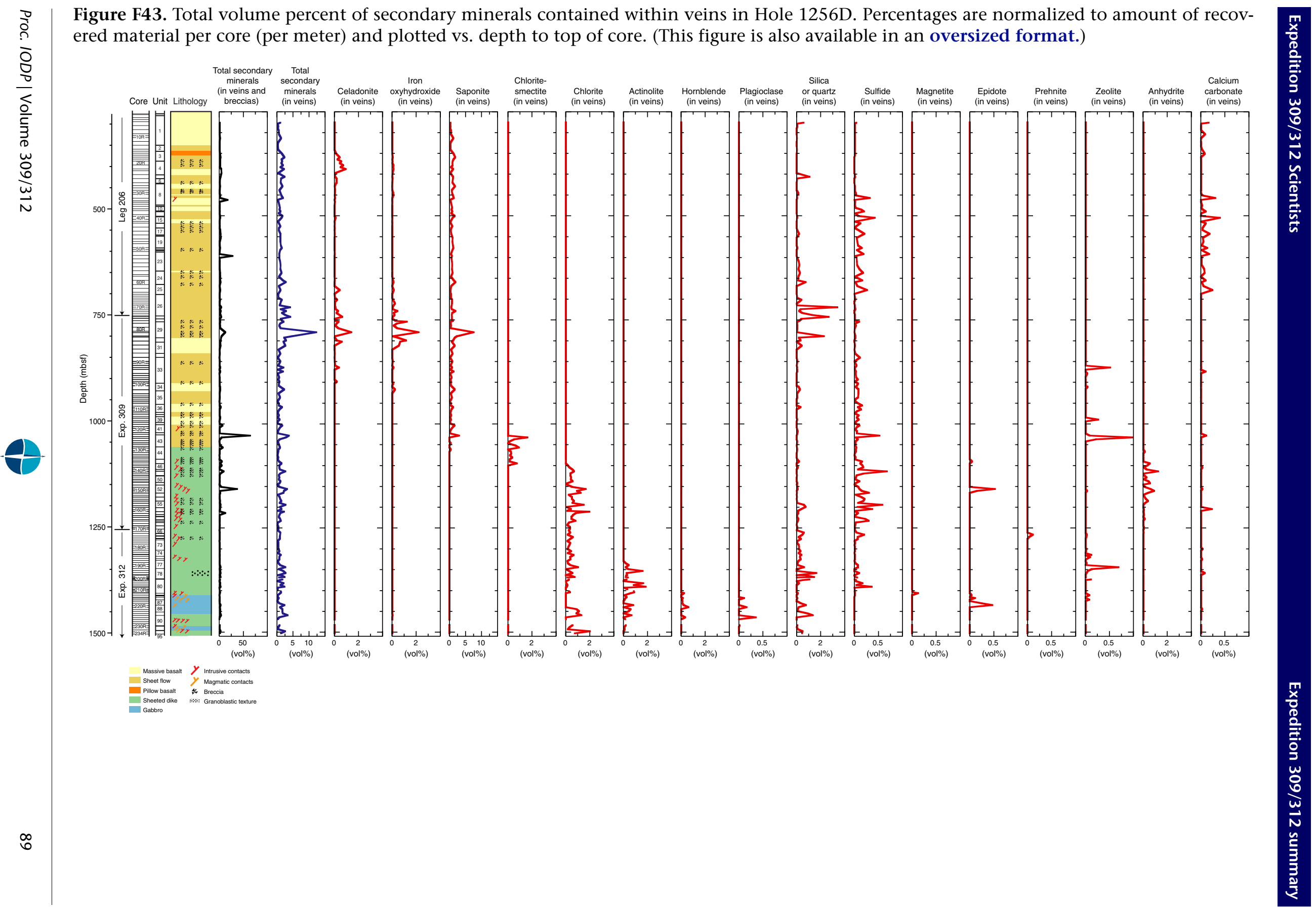

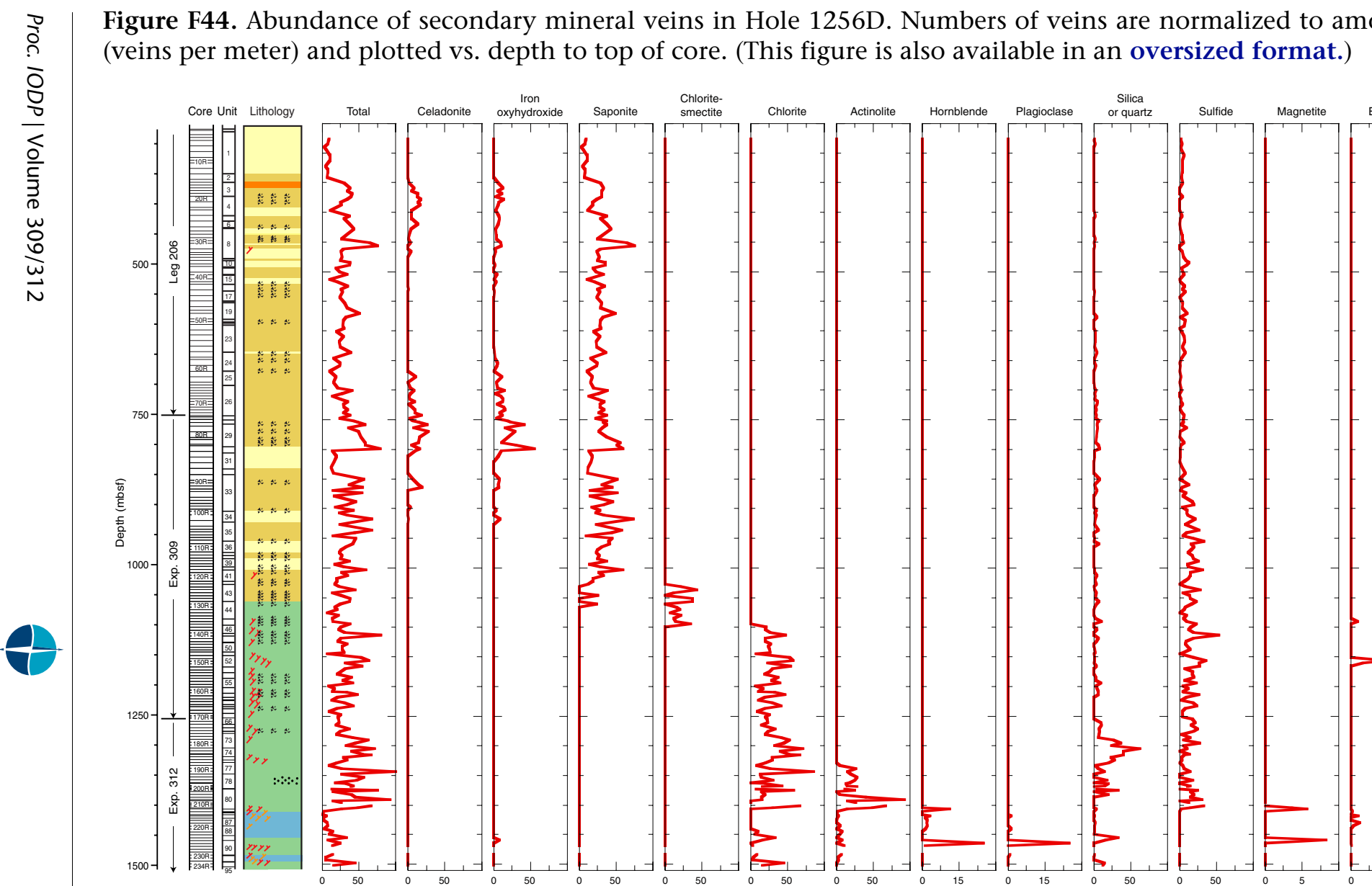

mount of recovered material per core veins per meter) and plotted vs. depth to top of core. (This figure is also available in an oversized format.)
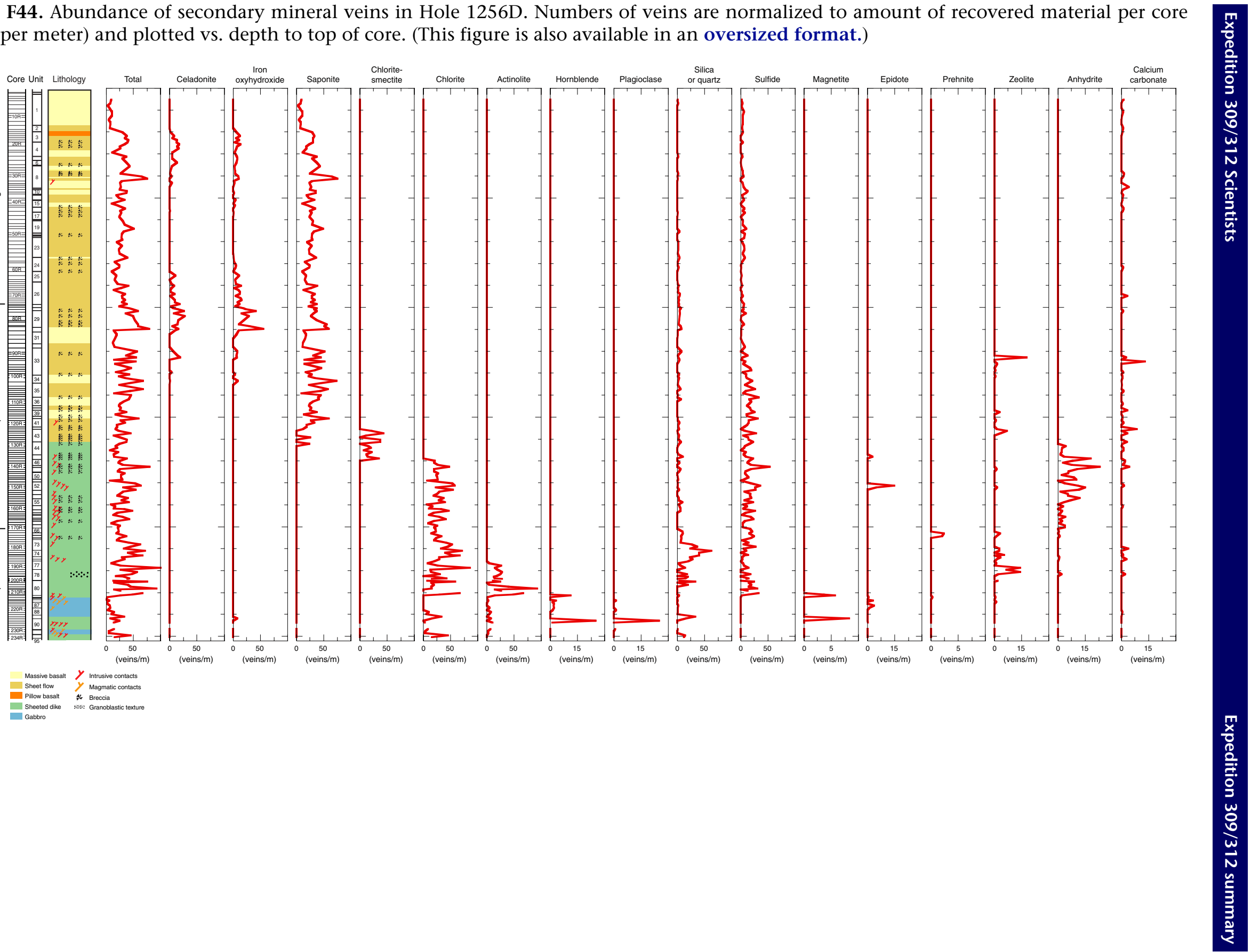


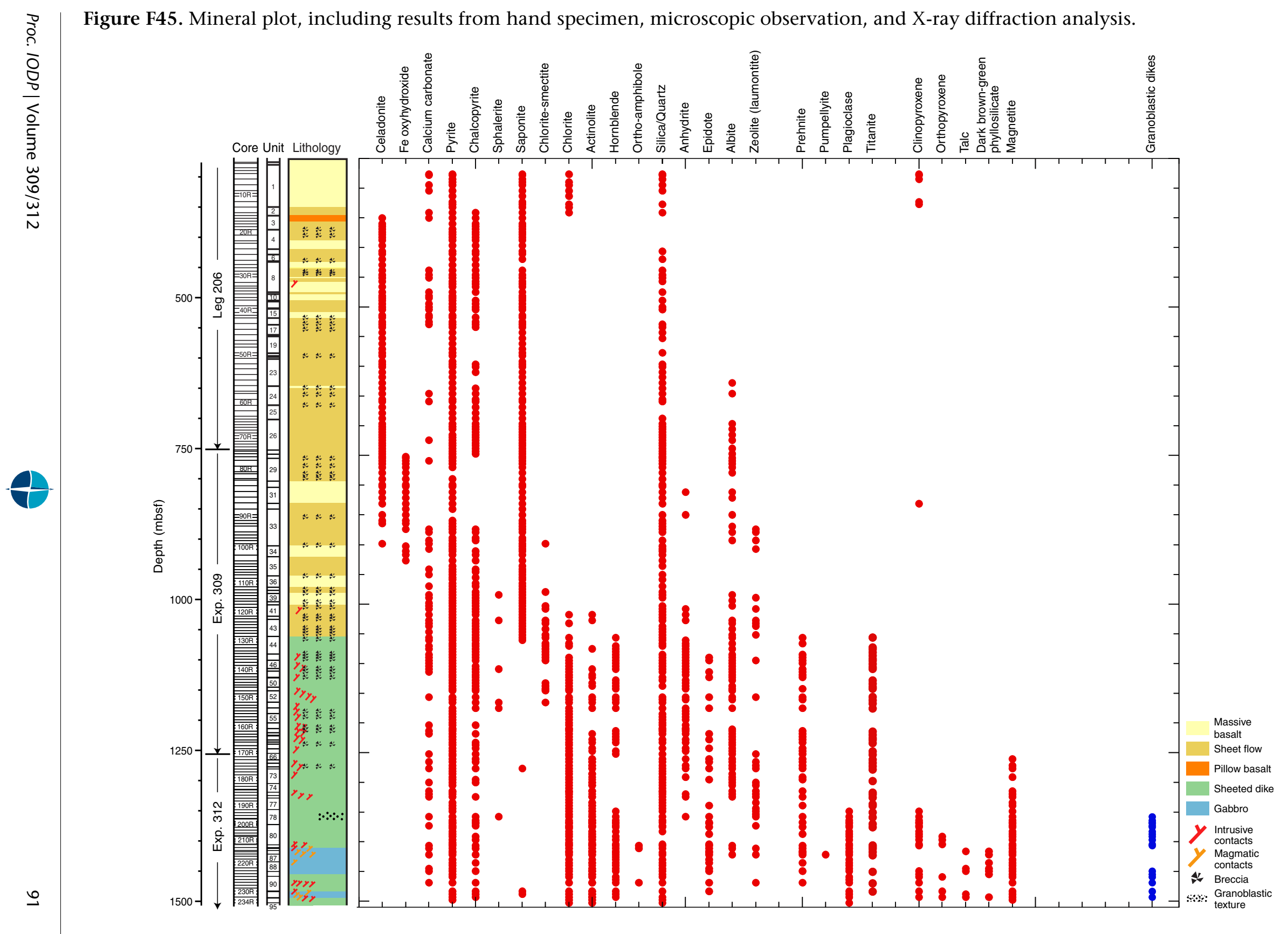


Figure F46. Downhole variations in alteration.

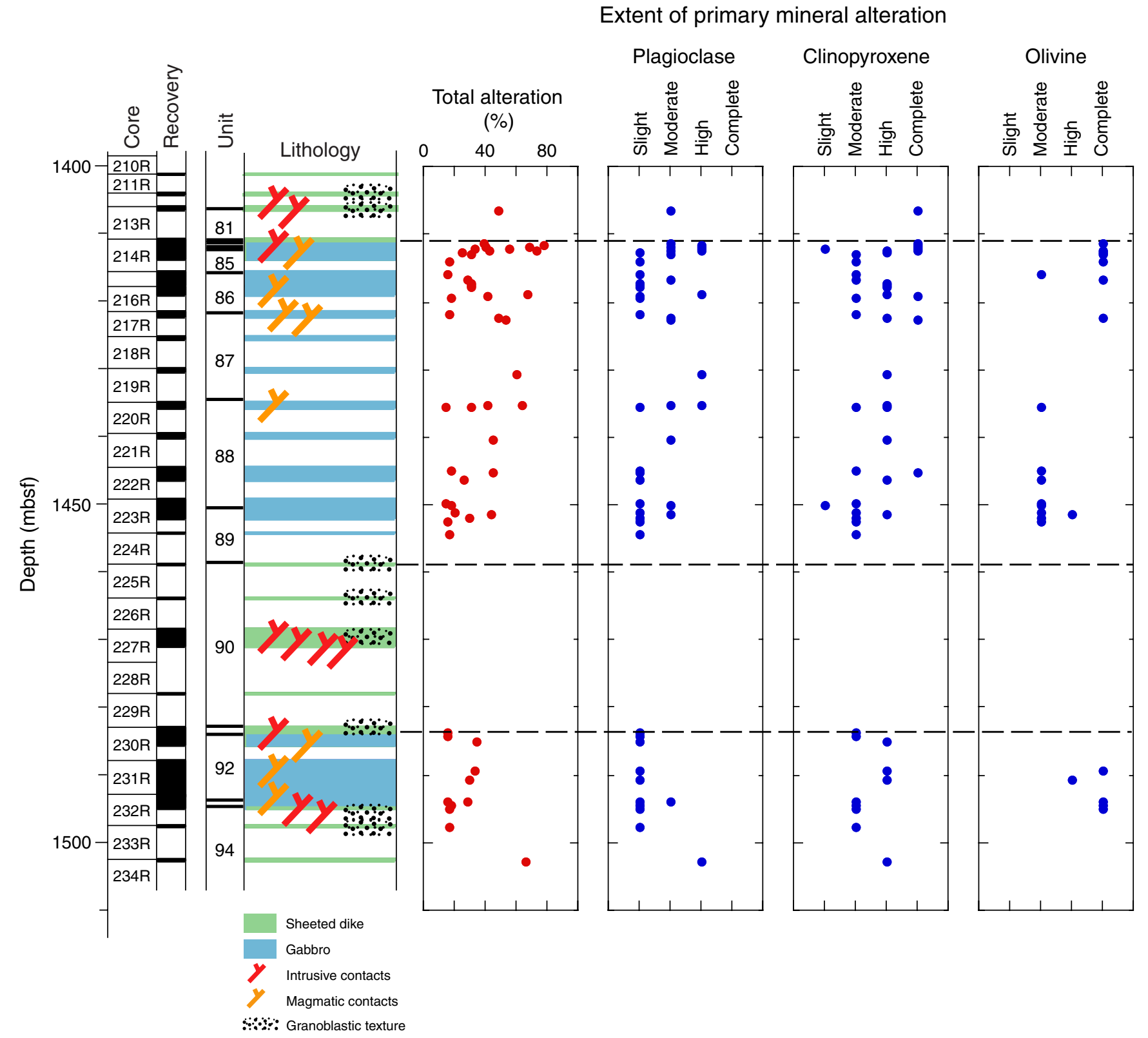


Figure F47. Comparison of lithostratigraphy and alteration types with depth in Holes 504B and 1256D. Low$\mathrm{T}$ = low temperature, $\mathrm{M} / \mathrm{l}$ chl-smec $=$ mixed-layer chlorite-smectite, upa = upper pillow alteration, lpa = lower pillow alteration.

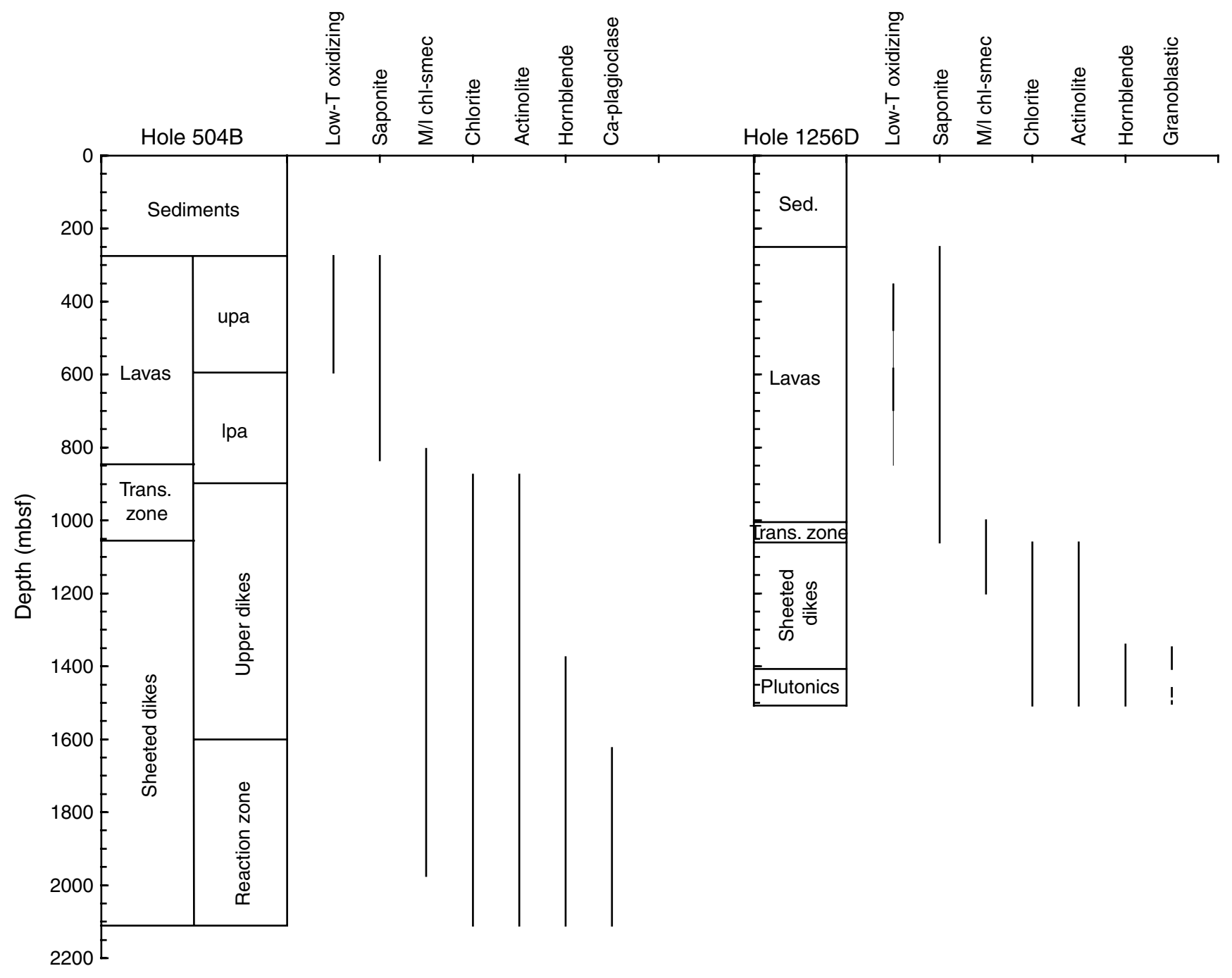


Figure F48. Downhole distribution of structural features.

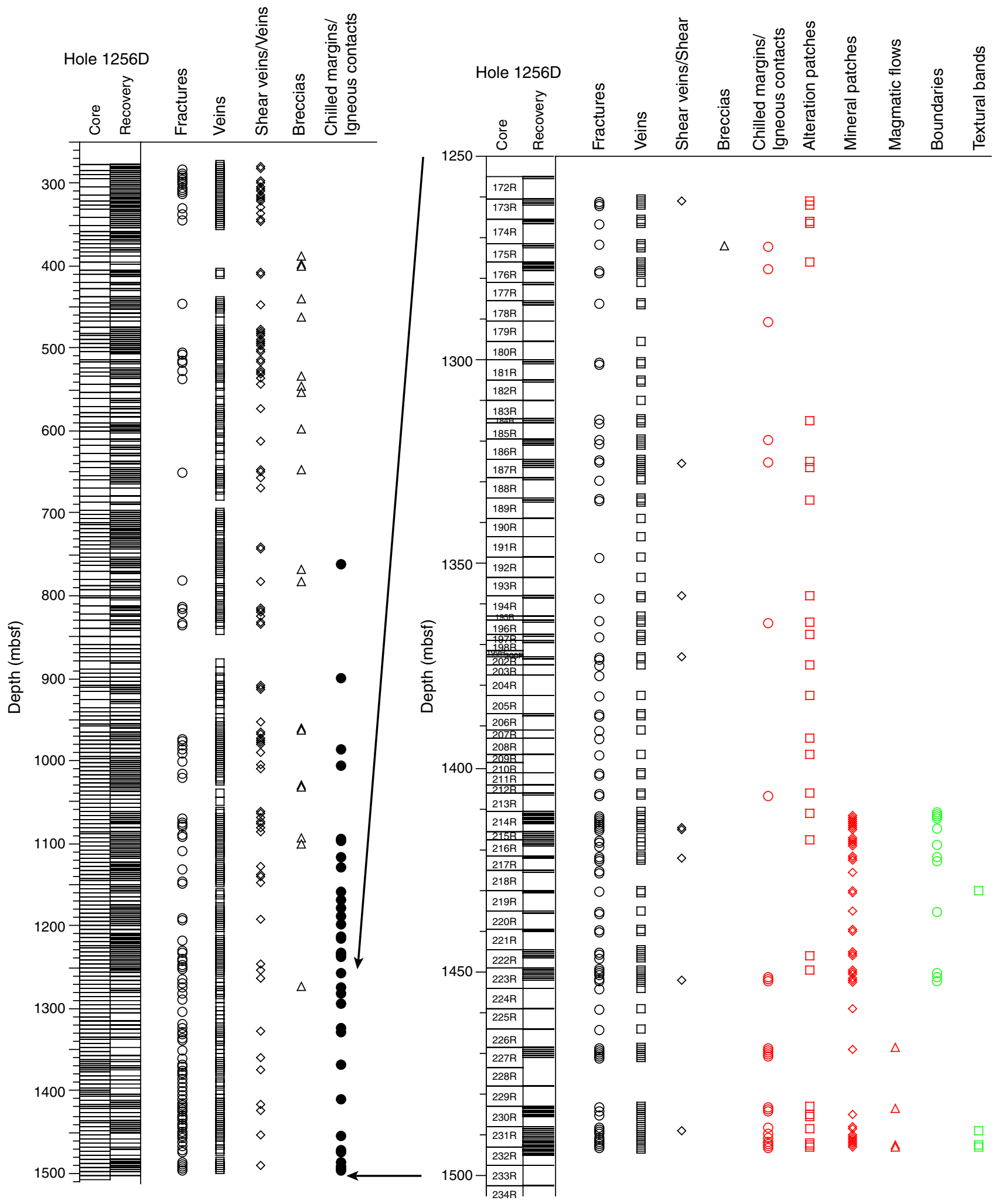


Figure F49. Cataclastic zone at contact with clast of chilled basalt (cataclastic massive unit) (Thin Section 67; Sample 309-1256D-117R-1 [Piece 12, 122-125 cm]). A. Core piece and thin section. B. Detail of thin section. Inset shows the crosscutting relationships between different events of veining ( 1 is the oldest); protocataclasite (protoc) and cataclasite are cut by ultracataclasite (ultracat) and gouge veins (plane-polarized light, blue filter; field of view $=10 \mathrm{~mm}$ ).
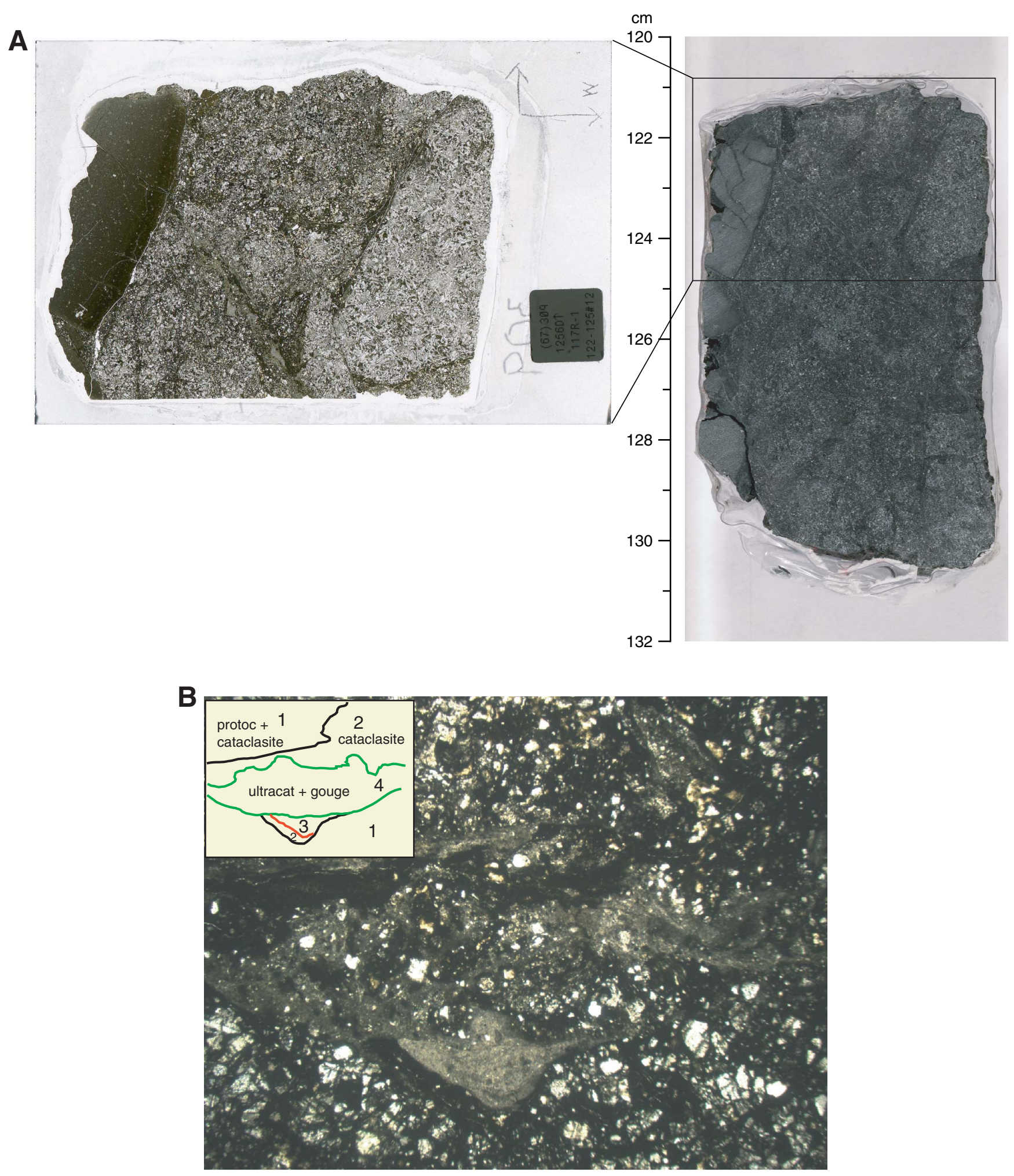
Figure F50. Downhole variation of the intensity of fracturing.

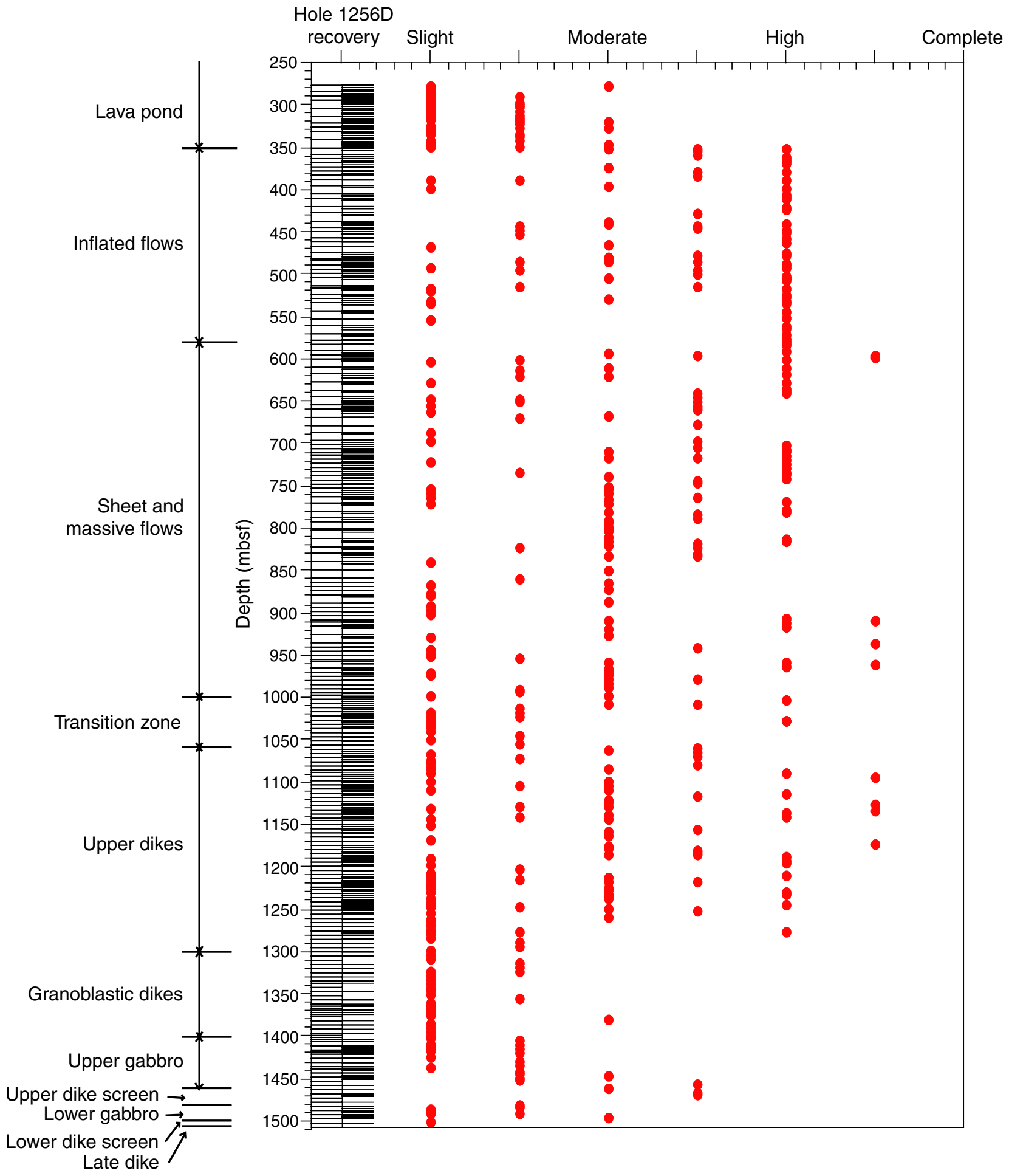


Figure F51. Subtype of hyaloclastite consisting of basalt clasts and altered glassy clasts and glassy shards cemented by quartz, carbonate, and sulfide (mineralized volcanic breccia). A. Thin section (Thin Section 80; Sample 309-1256D-122R-1 [Piece 19, 140-143 cm]). B. Spherulitic texture in cryptocrystalline basalt clasts of the hyaloclastite (Thin Section 78; Sample 309-1256D-122R-1 [Piece 16, 119-124 cm]) (plane-polarized light, blue filter; field of view $=5 \mathrm{~mm}$ ). Light spots are sulfides.

A

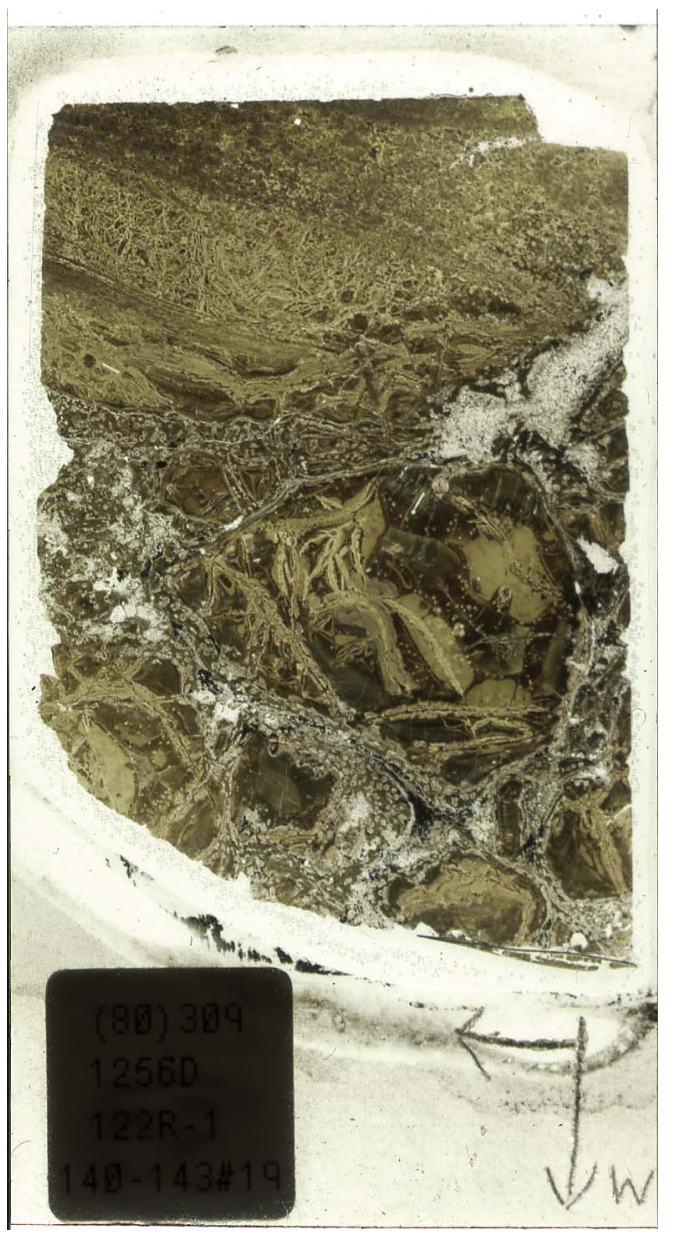

B

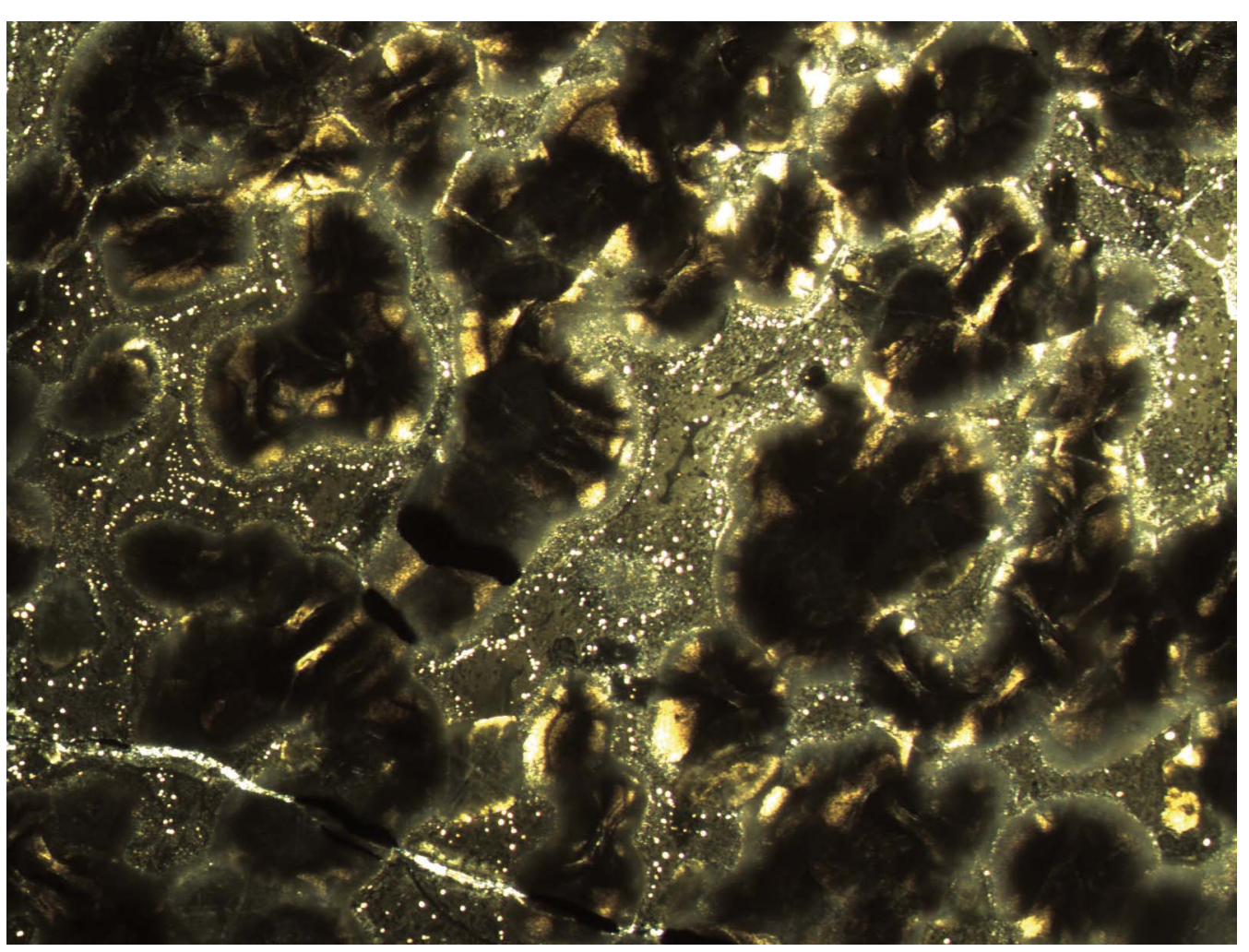


Figure F52. Hyaloclastic breccias characterized by different colors linked to alteration of clasts and matrix from the same core. A. Green bluish breccia (interval 309-1256D-122R-1, 29-51 cm). B. Light green breccia (interval 309-1256D-122R-1, 105-125 cm).

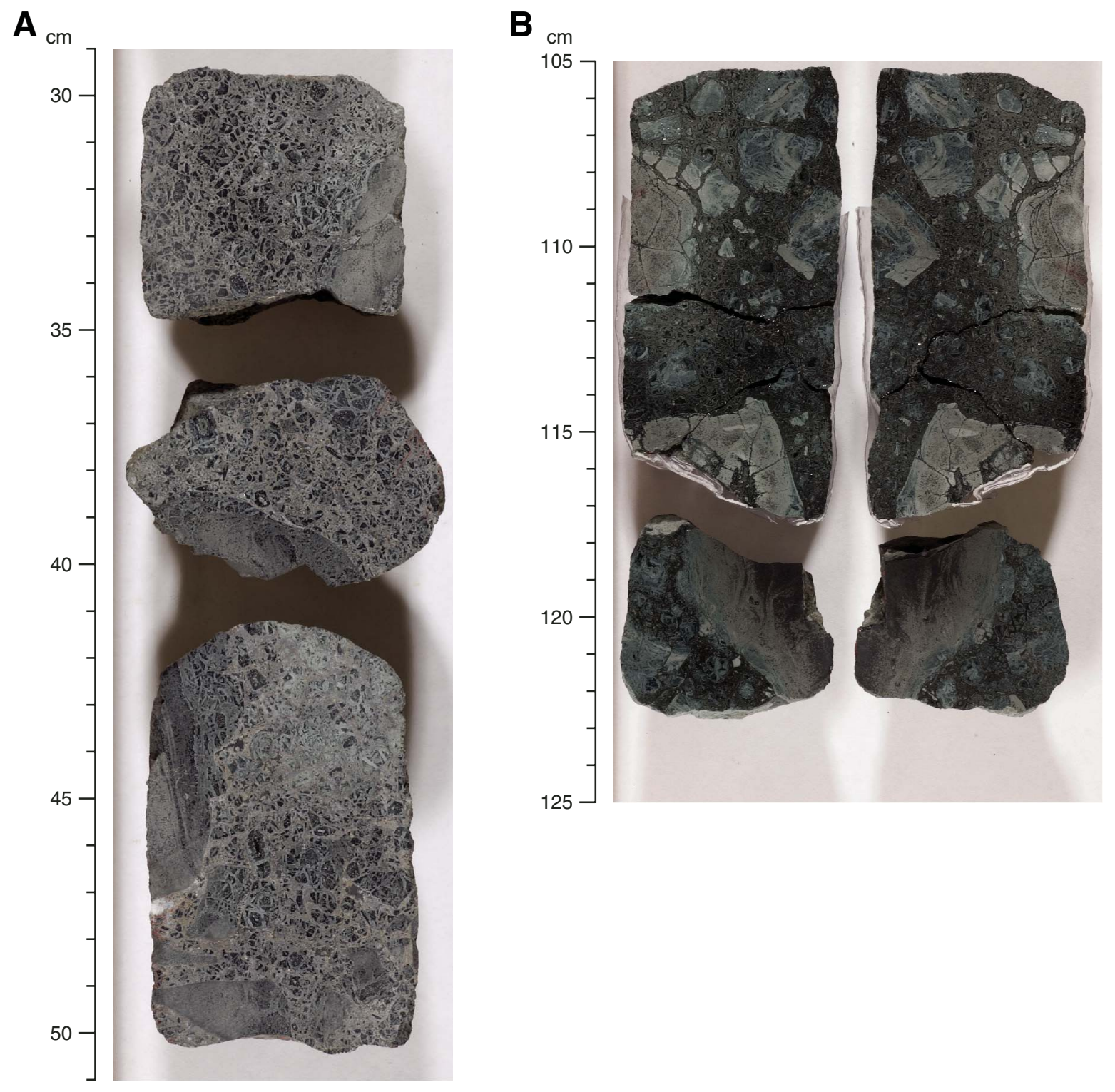


Figure F53. Cataclastic zone at dike contact characterized by flow structures and multiple veining. Veins have dilational features and different mineral fillings; clear crosscutting relationships are visible. A. Close-up of core (interval 309-1256D-140R-1, 41-59 cm). B. Close-up of thin section (Thin Section 117; Sample 3091256D-140R-1, 75-79 cm).

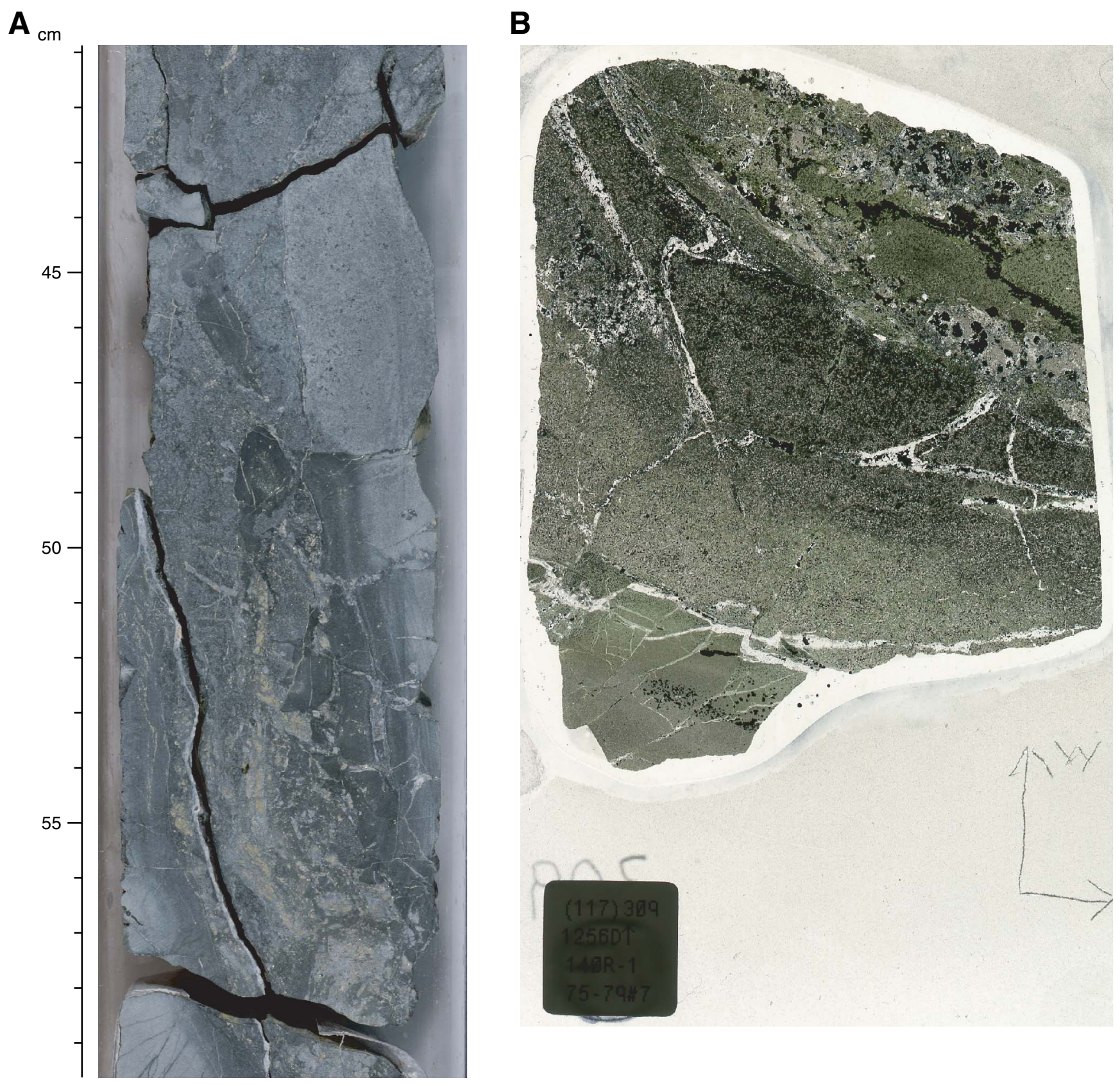


Figure F54. Dips of structural features.
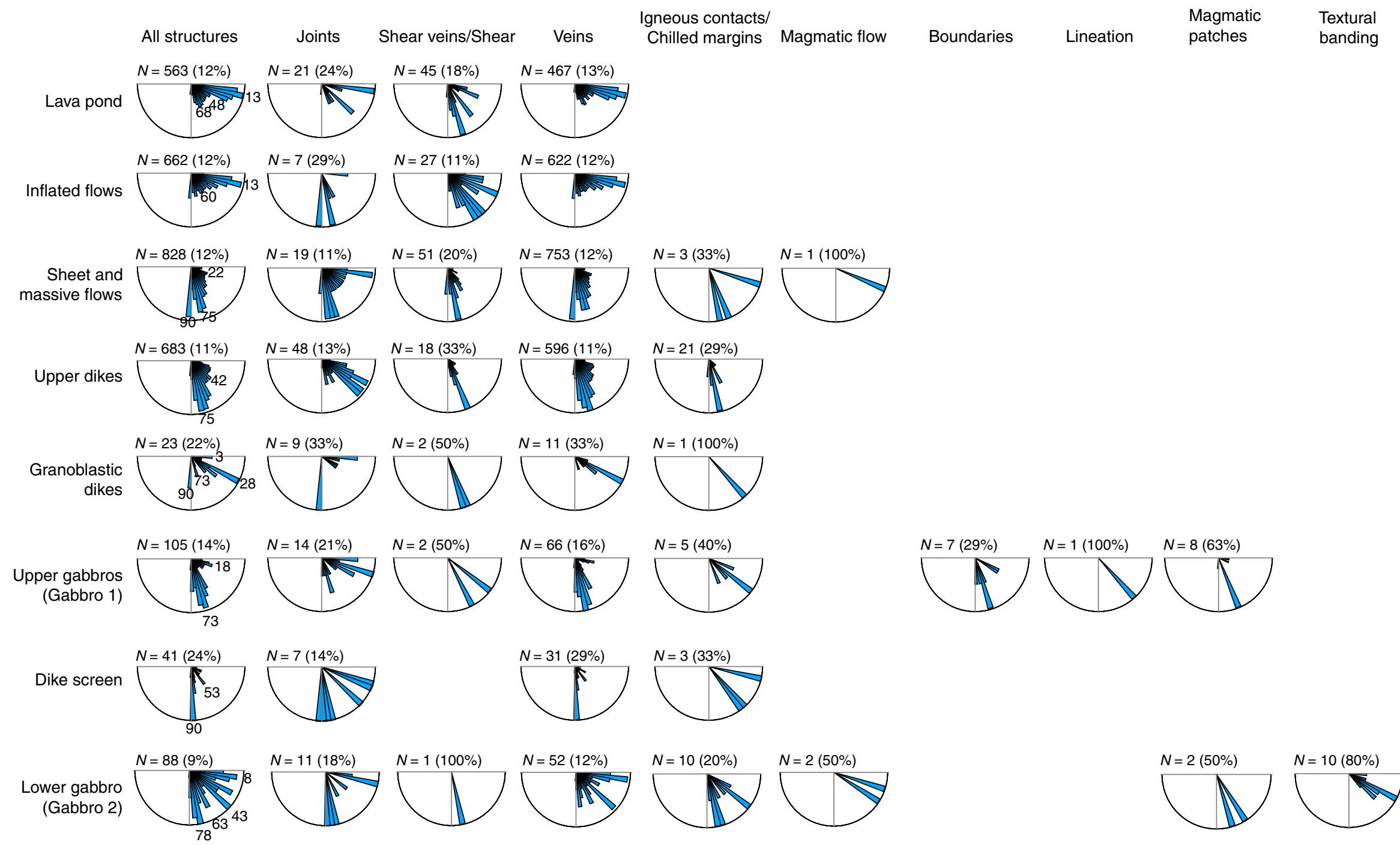
Figure F55. Alternating-field demagnetization behavior of one of the most stable samples studied (discrete Sample 309-1256D-161R-2, 21-23 cm). Normalized intensity vs. demagnetization level is at upper left; component diagrams and direction plots are on the right. Dots on the data table and double squares on the intensity plot $=$ values used for principal component analysis (PCA), with results listed at top left. High demagnetization (Demag) fields are required to reduce the intensity, and inclination (Inc) changes at progressive demagnetization steps are smaller than for other samples. Dec $=$ declination, $\mathrm{MAD}=$ maximum angular deviation.

File name: $161 \mathrm{r} 2-21$

Sample code: 309-1256D-161R-2, $21 \mathrm{~cm} ; 1211.91 \mathrm{mbsf}$

PCA - Dec: $67.4^{\circ}$ Inc: $22.7^{\circ} \quad$ MAD $=2.4$
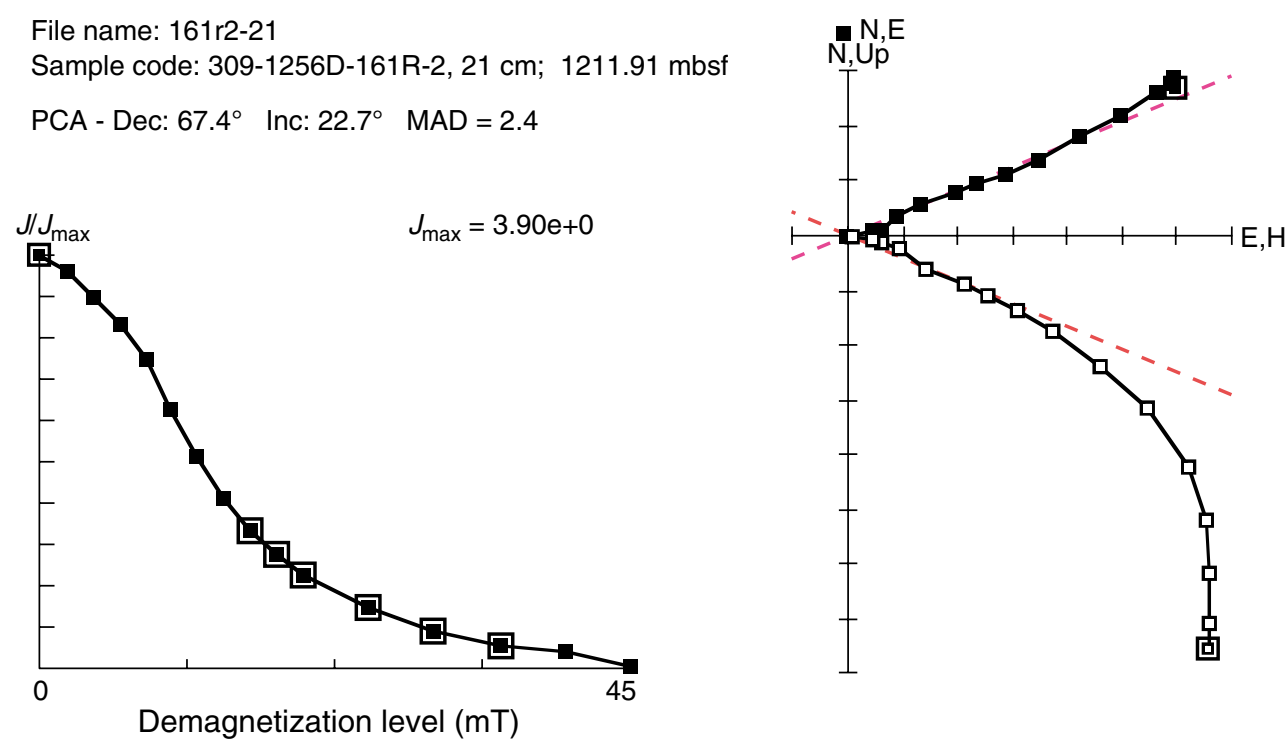

\begin{tabular}{|c|c|c|c|}
\hline Demag $(\mathrm{mT})$ & $\operatorname{Dec}\left({ }^{\circ}\right)$ & $\operatorname{lnc}\left({ }^{\circ}\right)$ & Intensity $(\mathrm{A} / \mathrm{m})$ \\
\hline 0.0 & 65.5 & 49.0 & $3.90 \mathrm{e}+0$ \\
\hline 2.0 & 64.5 & 47.0 & $3.76 \mathrm{e}+0$ \\
\hline 4.0 & 64.0 & 43.0 & $3.51 e+0$ \\
\hline 6.0 & 64.4 & 38.4 & $3.25 e+0$ \\
\hline 8.0 & 64.8 & 34.0 & $2.92 \mathrm{e}+0$ \\
\hline 10.0 & 66.0 & 29.9 & $2.44 e+0$ \\
\hline 12.0 & 66.8 & 27.4 & $2.02 \mathrm{e}+0$ \\
\hline 14.0 & 67.6 & 24.7 & $1.61 e+0$ \\
\hline 16.0 & 67.8 & 23.5 & $1.30 \mathrm{e}+0$ \\
\hline $18.0 \bullet$ & 66.9 & 23.2 & $1.07 e+0$ \\
\hline 20.0 & 67.5 & 22.6 & $8.86 e-1$ \\
\hline 25.0 & 65.3 & 22.2 & $5.98 e-1$ \\
\hline 30.0 & 66.3 & 14.2 & $3.74 \mathrm{e}-1$ \\
\hline $35.0 \bullet$ & 76.8 & 11.8 & $2.34 \mathrm{e}-1$ \\
\hline 40.0 & 73.6 & 4.0 & $1.71 e-1$ \\
\hline 45.0 & 266.1 & -2.8 & $1.78 e-2$ \\
\hline
\end{tabular}
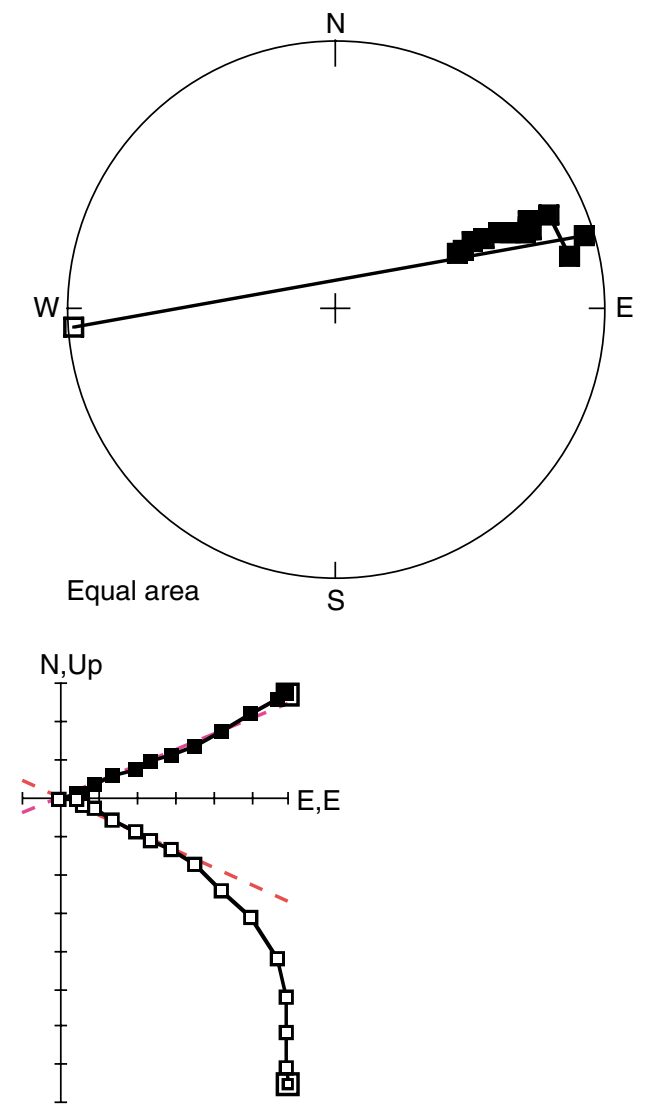
Figure F56. A. Intensity variation in demagnetized archive-half samples that correlate with petrographic igneous units. From left to right: single behavior, multiple behavior, and irregular behavior. B. Frequency of thickness $(\mathrm{m})$ of concave shapes.

A

A Magnetic intensity

$(30 \mathrm{mT})$
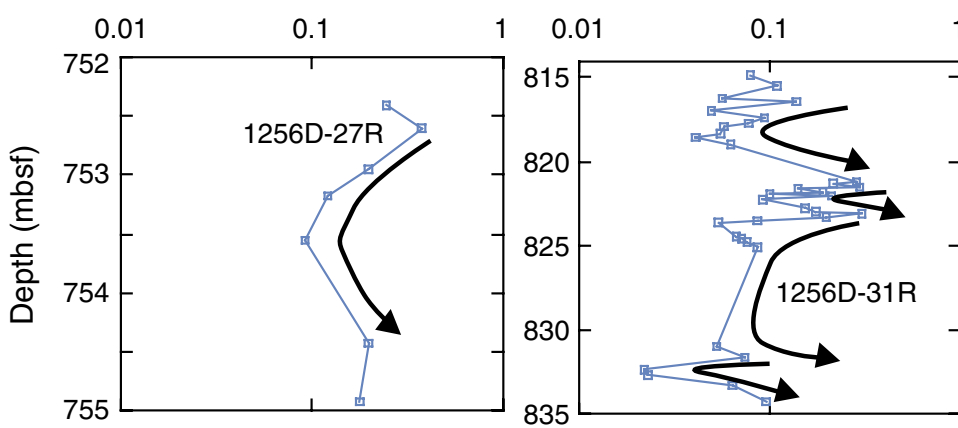

Magnetic intensity

(30 mT)

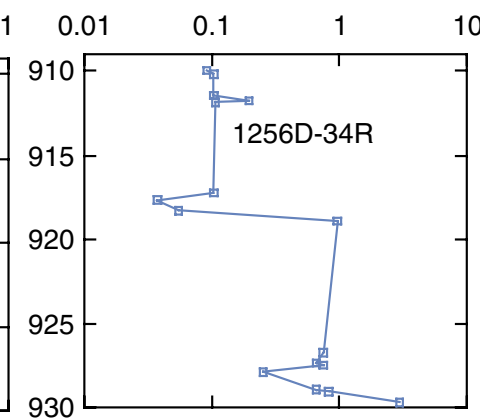

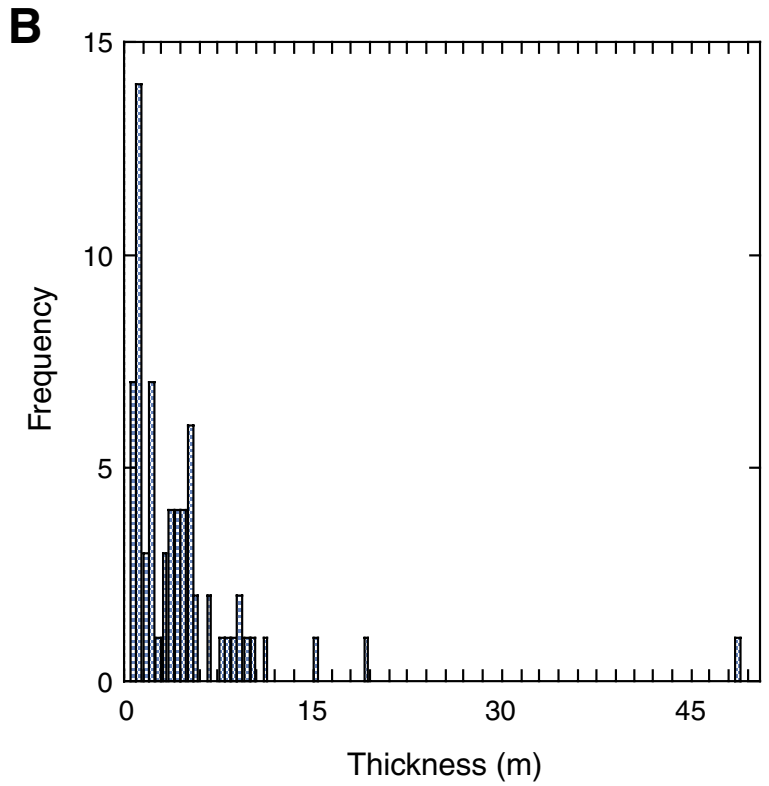


Figure F57. Alternating-field demagnetization behavior of a sample typical of the depth interval from 1256 to 1400 mbsf (discrete Sample 312-1256D-196R-1, 30-32 cm). Normalized intensity vs. demagnetization level is at upper left; component diagrams and direction plots are on the right. Directions show a smooth progression toward shallow inclinations but without a clear end point.

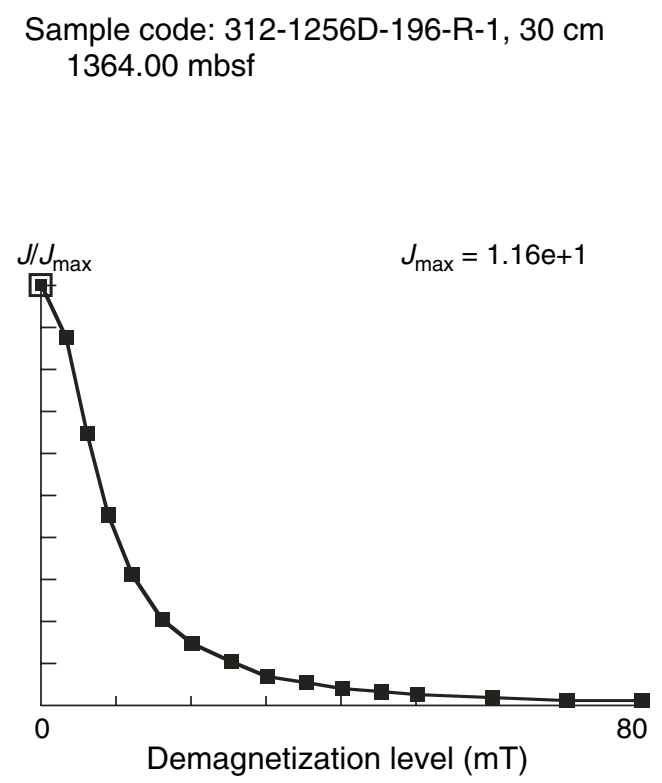

\begin{tabular}{|c|c|c|c|}
\hline Demag $(\mathrm{mT})$ & Dec $\left(^{\circ}\right)$ & Inc $\left(^{\circ}\right)$ & Intensity $(\mathrm{A} / \mathrm{m})$ \\
\hline 0.0 & 173.2 & 69.5 & $1.16 \mathrm{e}+1$ \\
\hline 3.0 & 168.2 & 70.7 & $1.02 \mathrm{e}+1$ \\
\hline 6.0 & 162.2 & 70.2 & $7.52 \mathrm{e}+0$ \\
\hline 9.0 & 155.3 & 69.6 & $5.32 \mathrm{e}+0$ \\
\hline 12.0 & 147.9 & 68.0 & $3.66 \mathrm{e}+0$ \\
\hline 16.0 & 138.5 & 65.9 & $2.44 \mathrm{e}+0$ \\
\hline 20.0 & 130.3 & 63.8 & $1.77 \mathrm{e}+0$ \\
\hline 25.0 & 121.2 & 60.4 & $1.23 \mathrm{e}+0$ \\
\hline 30.0 & 112.3 & 55.6 & $8.57 \mathrm{e}-1$ \\
\hline 35.0 & 105.8 & 49.8 & $6.30 \mathrm{e}-1$ \\
\hline 40.0 & 100.0 & 44.9 & $5.10 \mathrm{e}-1$ \\
\hline 45.0 & 97.4 & 39.1 & $4.01 \mathrm{e}-1$ \\
\hline 50.0 & 92.5 & 33.4 & $3.23 \mathrm{e}-1$ \\
\hline 60.0 & 86.7 & 23.9 & $2.19 \mathrm{e}-1$ \\
\hline 70.0 & 83.9 & 16.9 & $1.70 \mathrm{e}-1$ \\
\hline 80.0 & 82.0 & 10.8 & $1.34 \mathrm{e}-1$ \\
\hline
\end{tabular}

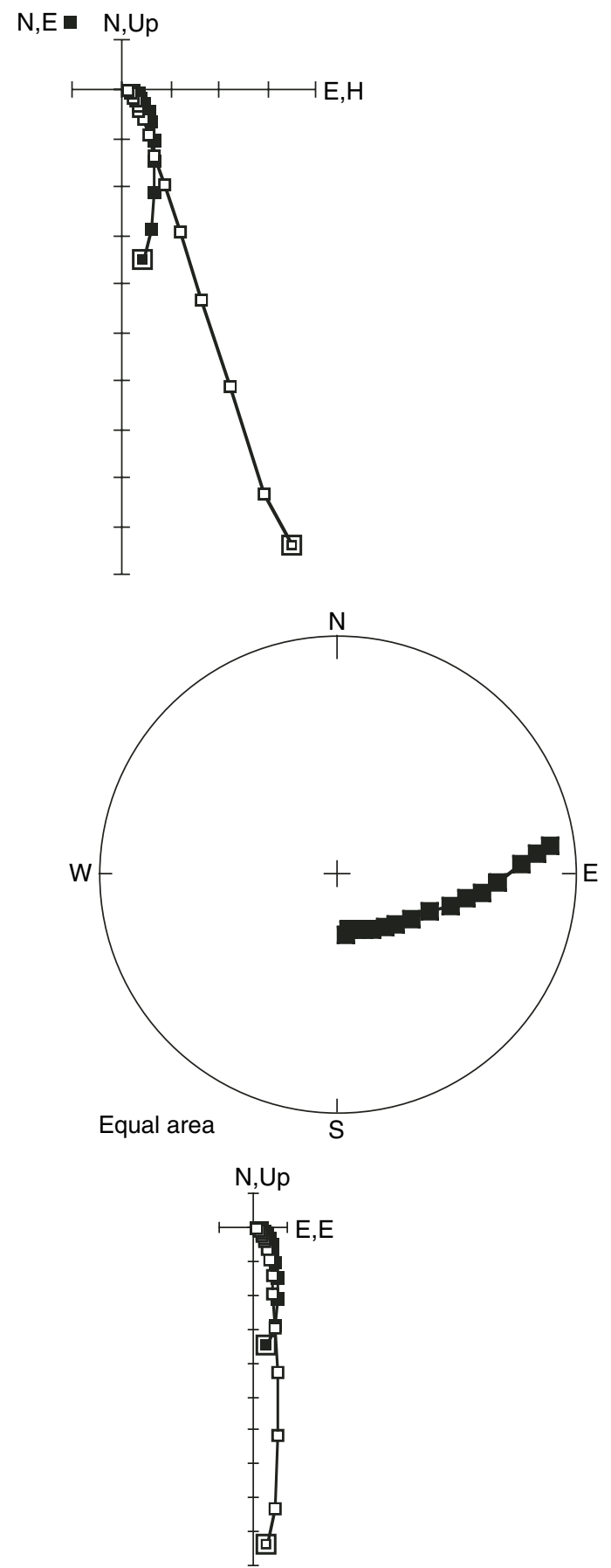


Figure F58. Alternating-field demagnetization behavior of a typical gabbro sample (Thin Section 111; discrete Sample 312-1256D-231R-2, 13-16 cm). Normalized intensity vs. demagnetization level is at upper left; component diagrams and direction plots are on the right.

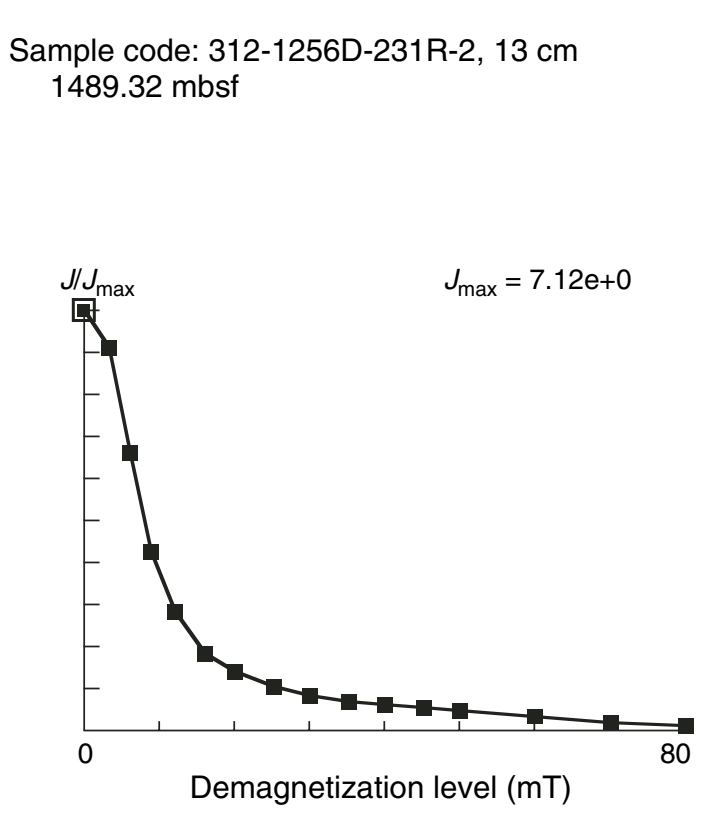

\begin{tabular}{|c|c|c|c|}
\hline Demag $(\mathrm{mT})$ & Dec $\left(^{\circ}\right)$ & Inc $\left(^{\circ}\right)$ & Intensity $(\mathrm{A} / \mathrm{m})$ \\
\hline 0.0 & 178.5 & 63.9 & $7.12 \mathrm{e}+0$ \\
\hline 3.0 & 183.9 & 66.0 & $6.53 \mathrm{e}+0$ \\
\hline 6.0 & 184.1 & 64.5 & $4.73 \mathrm{e}+0$ \\
\hline 9.0 & 186.9 & 60.3 & $3.07 \mathrm{e}+0$ \\
\hline 12.0 & 189.1 & 55.3 & $2.02 \mathrm{e}+0$ \\
\hline 16.0 & 191.6 & 47.4 & $1.34 \mathrm{e}+0$ \\
\hline 20.0 & 194.5 & 39.5 & $9.96 \mathrm{e}-1$ \\
\hline 25.0 & 195.2 & 32.5 & $7.69 \mathrm{e}-1$ \\
\hline 30.0 & 198.2 & 27.4 & $6.26 \mathrm{e}-1$ \\
\hline 35.0 & 198.9 & 24.2 & $5.33 \mathrm{e}-1$ \\
\hline 40.0 & 198.1 & 21.8 & $4.73 \mathrm{e}-1$ \\
\hline 45.0 & 197.4 & 20.0 & $4.10 \mathrm{e}-1$ \\
\hline 50.0 & 194.7 & 18.4 & $3.34 \mathrm{e}-1$ \\
\hline 60.0 & 195.1 & 17.0 & $2.41 \mathrm{e}-1$ \\
\hline 70.0 & 196.9 & 14.6 & $1.66 \mathrm{e}-1$ \\
\hline 80.0 & 195.3 & 14.4 & $1.16 \mathrm{e}-1$ \\
\hline
\end{tabular}
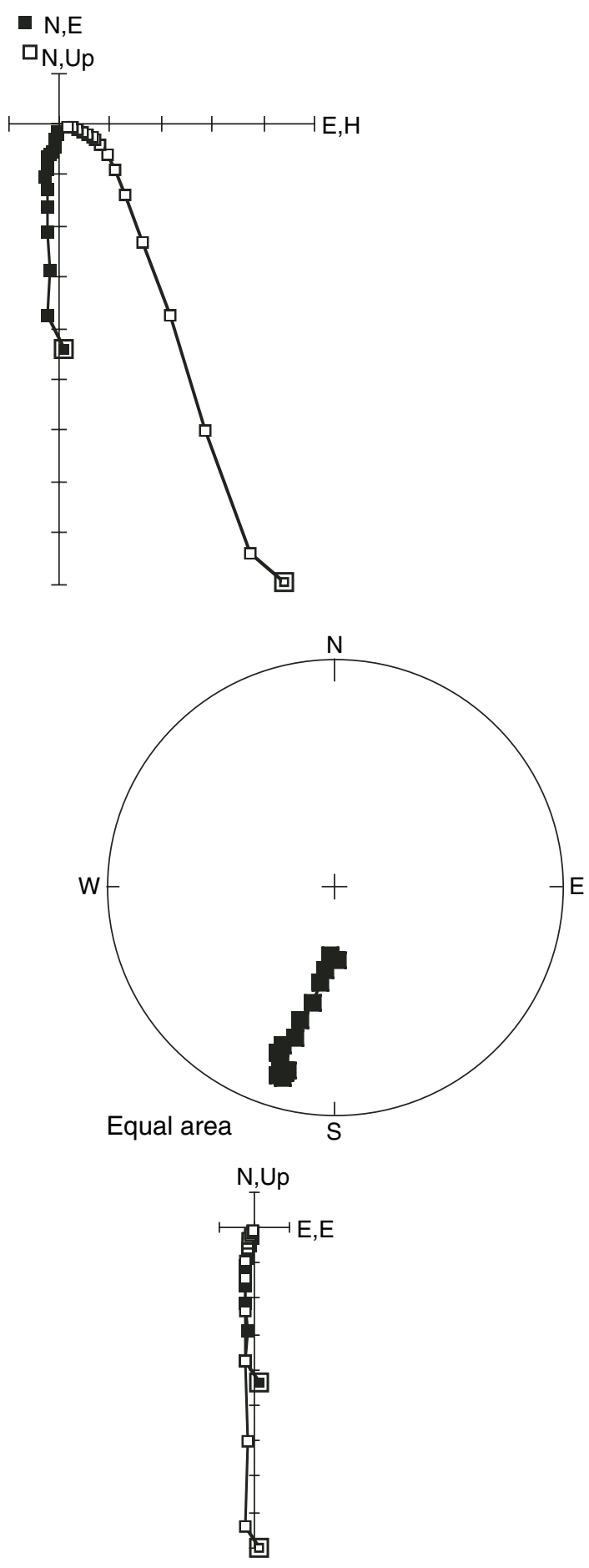
Figure F59. Expedition 312 inclinations. A. Archive-half results from last demagnetization. B. Results from intersections of working-half and archive-half trends.
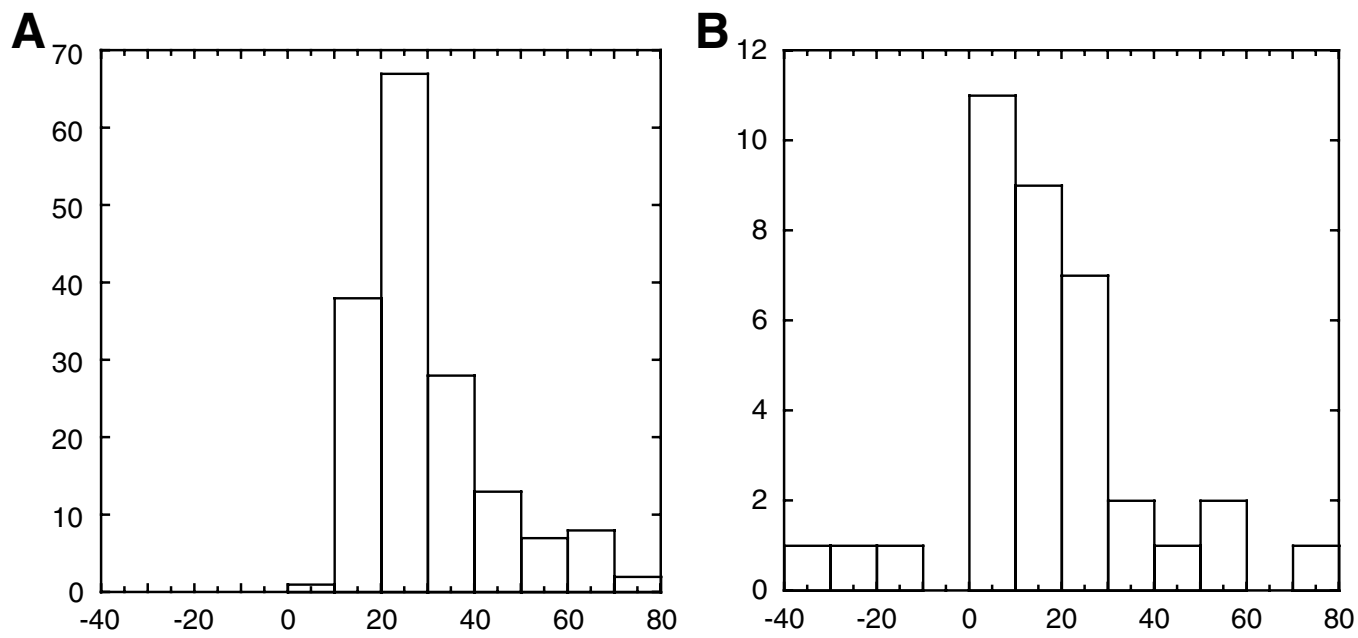
Figure F60. Inclination and declination vs. depth, with last good demagnetized direction plotted for the archive half and directions from intersection analysis, where well constrained, used for the working half.

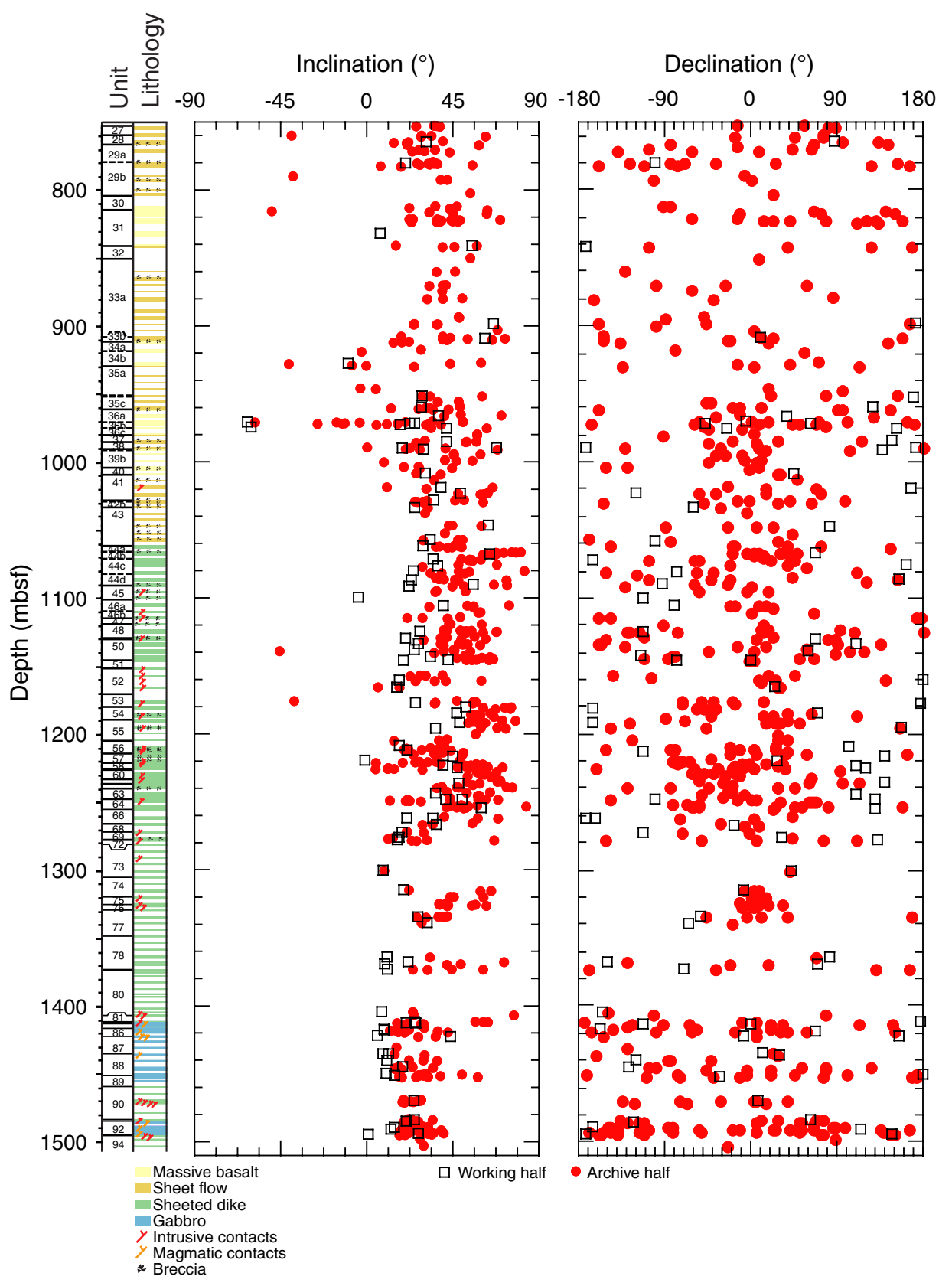


Figure F61. Downcore variations in (A) natural remanent magnetization (NRM) intensity, (B) ratio of intensity after $20 \mathrm{mT}$ demagnetization to NRM intensity, and (C) magnetic susceptibility.

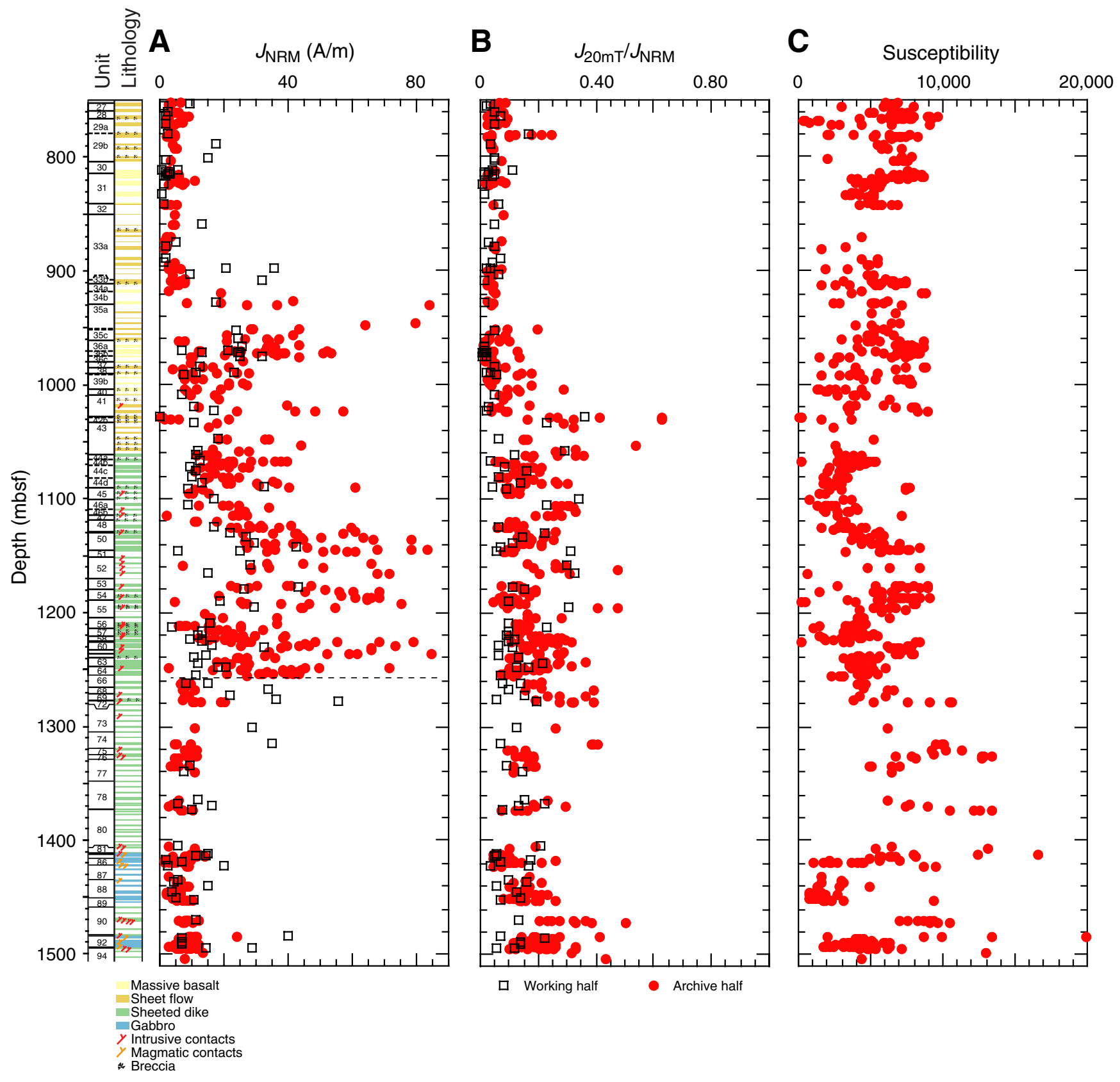


Figure F62. A-C. Discrete sample results (bulk density, porosity, $V_{\mathrm{p}}$, and thermal conductivity data) with lithologic summary. $V_{\mathrm{p}}$ measurements were made on discrete samples, and bulk density results were calculated using measured mass and volume of each discrete sample. Thermal conductivity was measured on half-round cores.

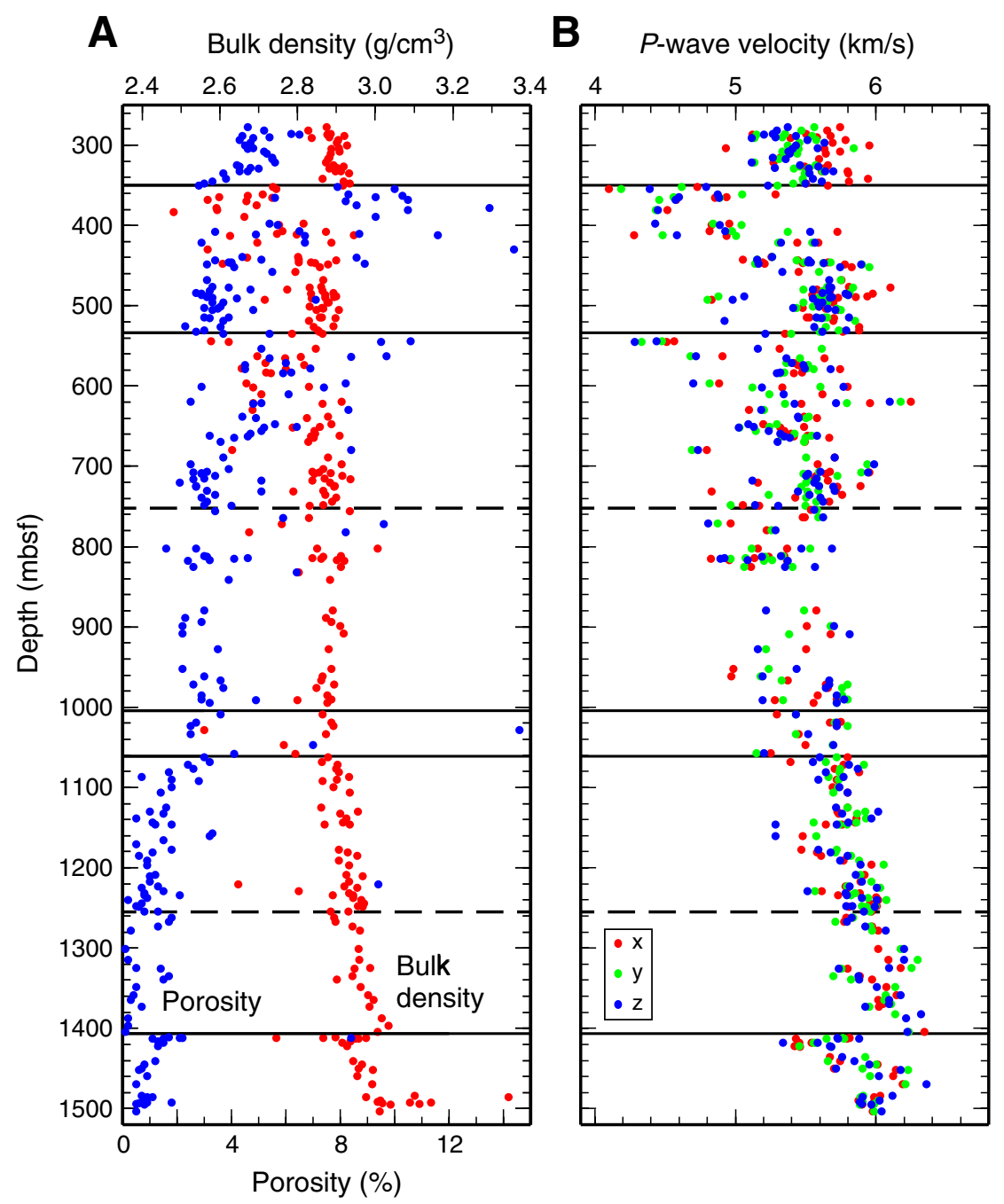

C Thermal conductivity $(\mathrm{W} /[\mathrm{m} \cdot \mathrm{K}])$

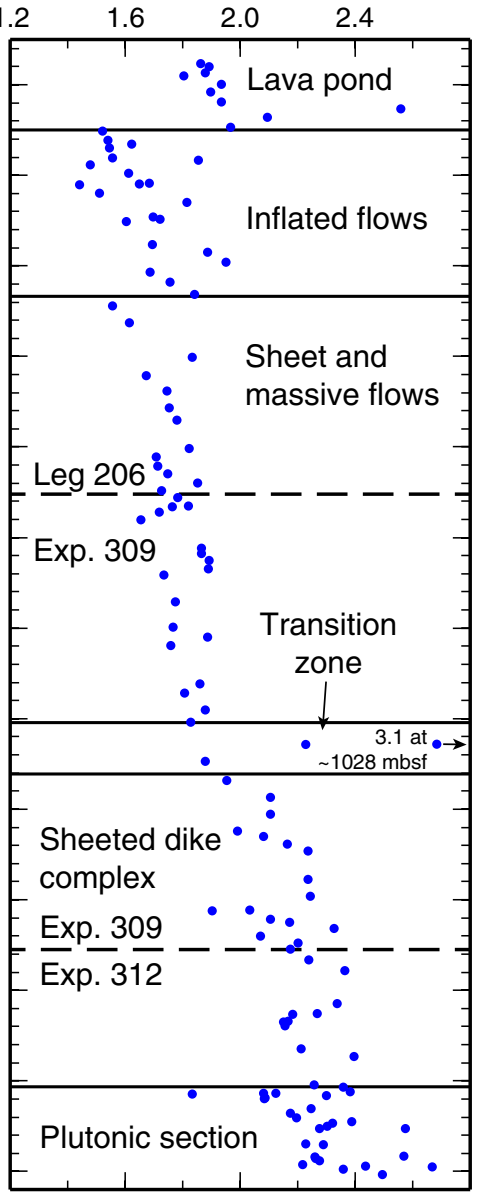


Figure F63. Variations in porosity with depth through Hole 1256D.
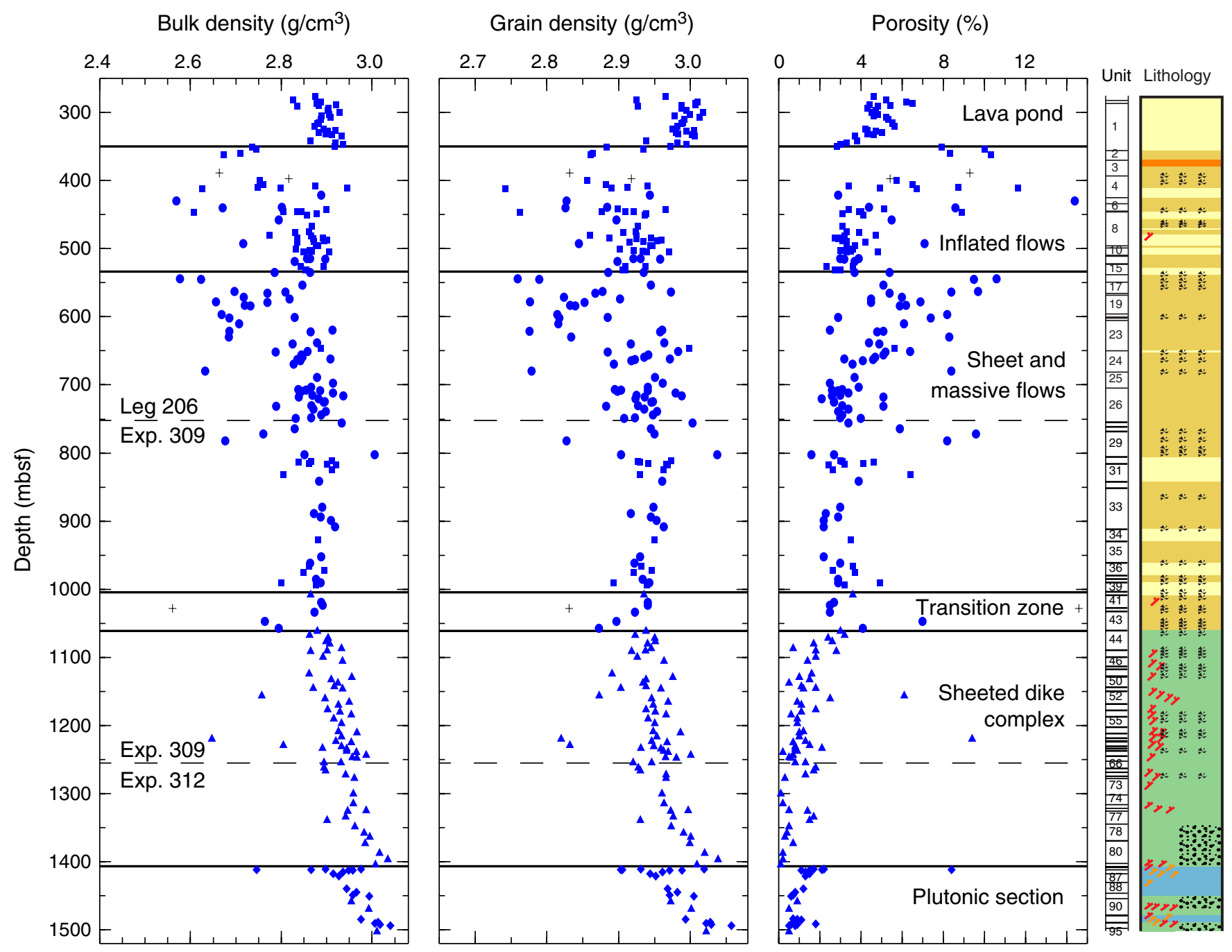

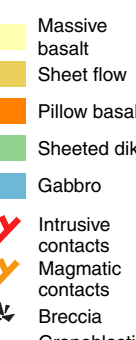
ar: $\begin{gathered}\text { Granoblastic } \\ \text { texture }\end{gathered}$ 
Figure F64. Selected preliminary logging measurements from Hole 1256D. FMS = Formation MicroScanner, HLDS = Hostile Environment Litho-Density Sonde, LLD = deep laterolog, LLS = shallow laterolog.

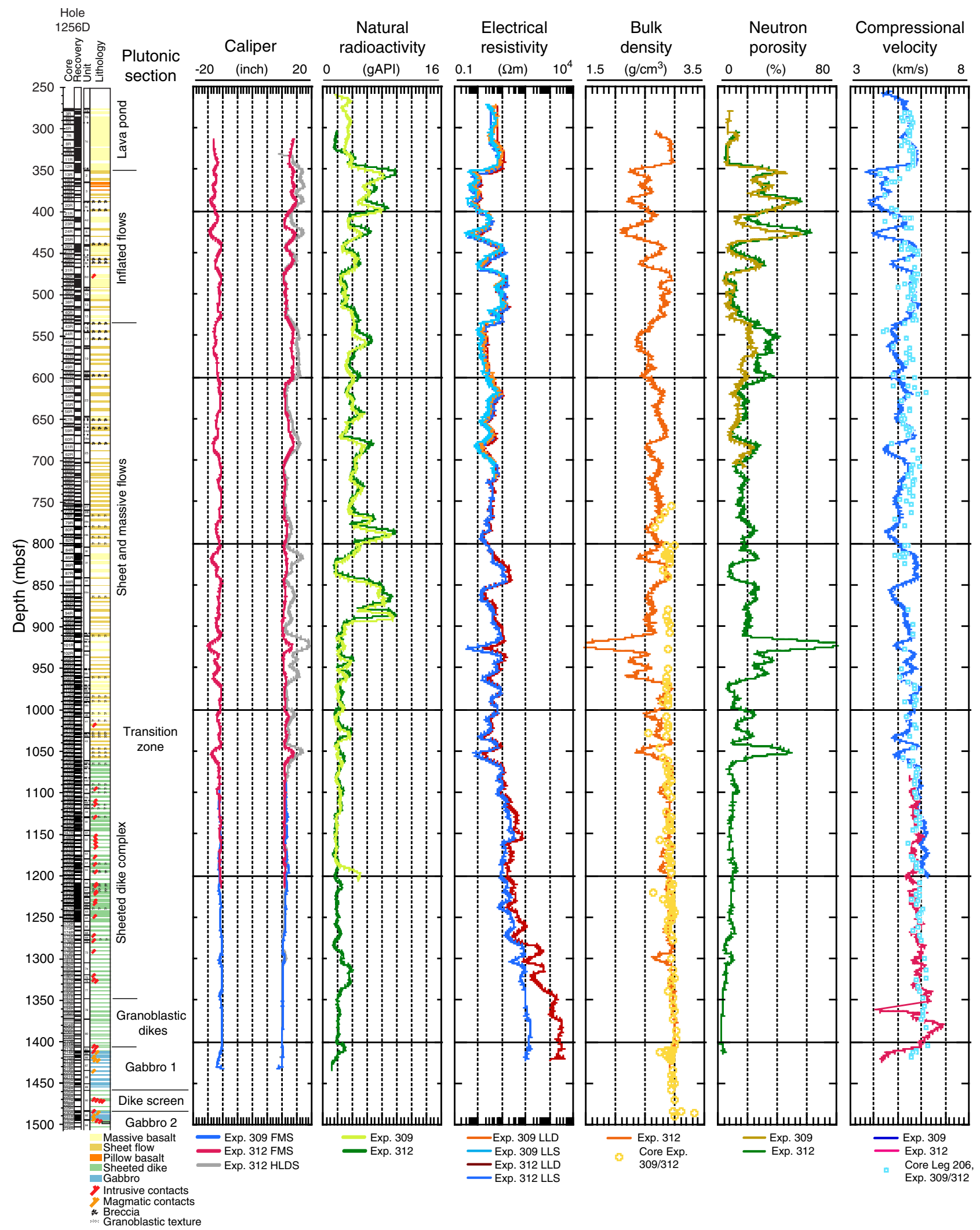


Figure F65. A. Temperature profiles of Hole 1256D measured with the TAP tool before the commencement of drilling operations (black curve) and after completion of drilling (red curve) and electrical resistivity measured with the Dual Laterolog. B. FMS data illustrating the correspondence of temperature anomalies with portions of the borehole with low resistivities (black interval).

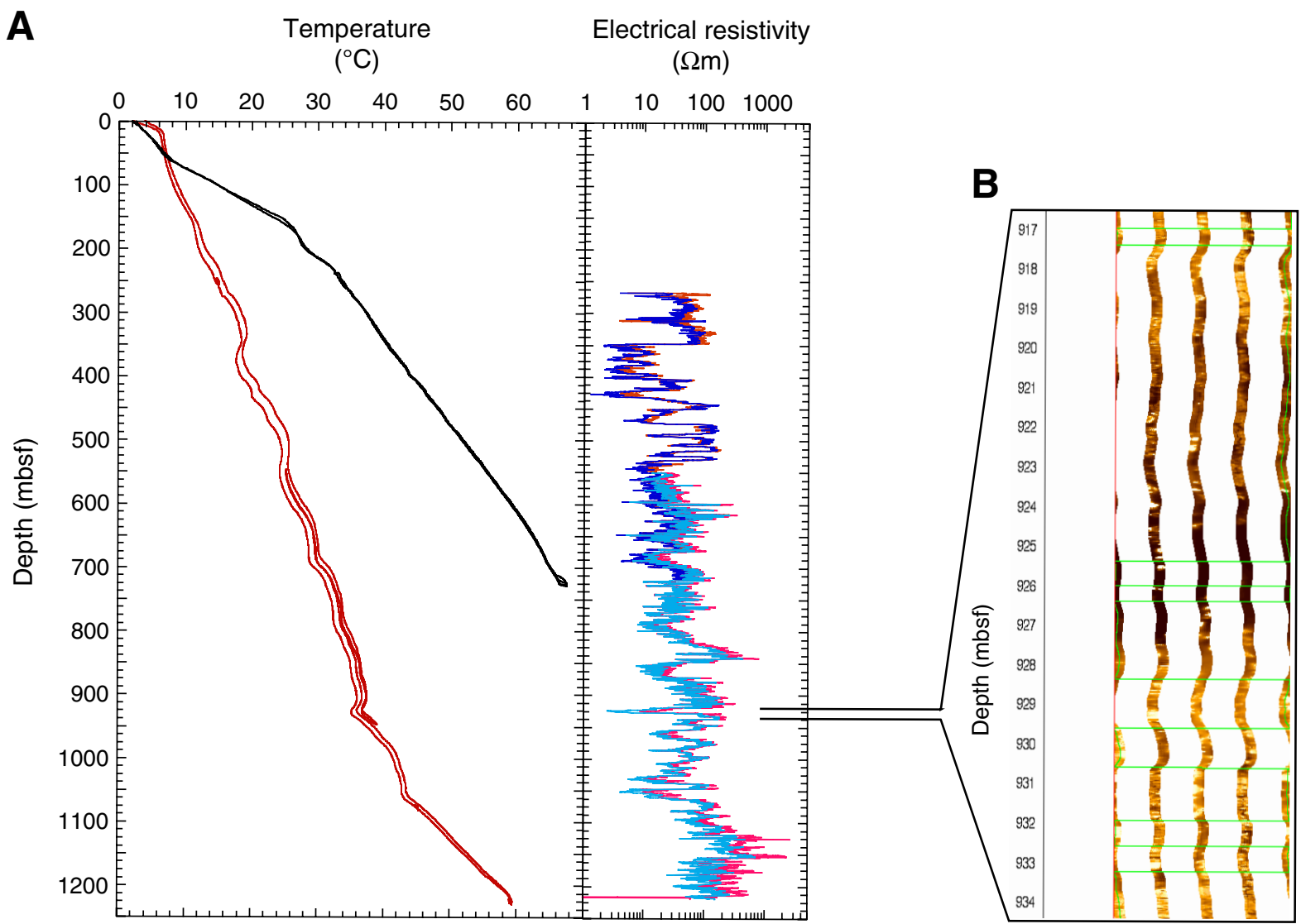


Figure F66. Logging results for sheeted dikes and gabbro. FMS = Formation MicroScanner, HLDS = Hostile Environment Litho-Density Sonde, LLD = deep laterolog, LLS = shallow laterolog.

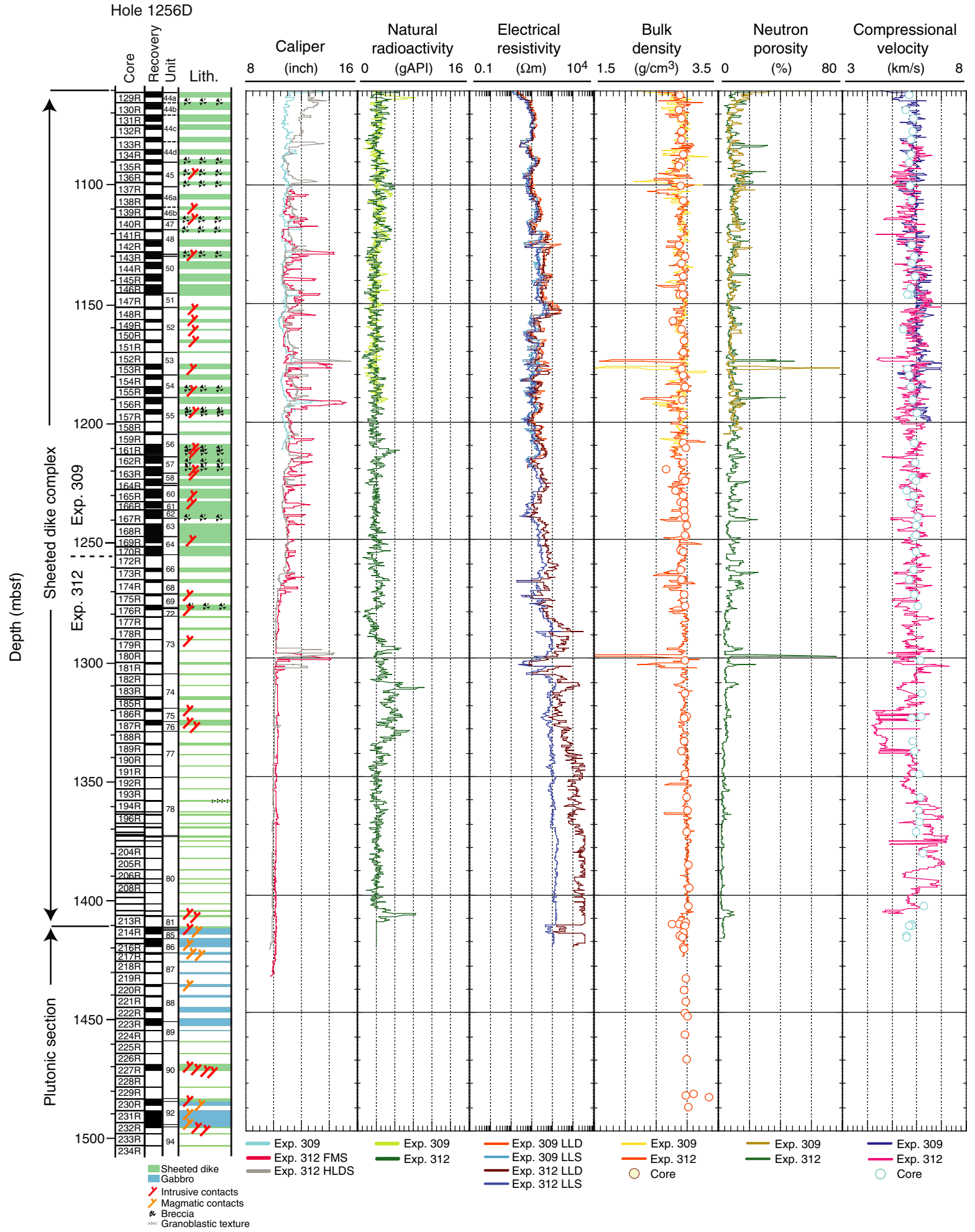


Figure F67. Bulk density and velocity from logs and discrete samples.

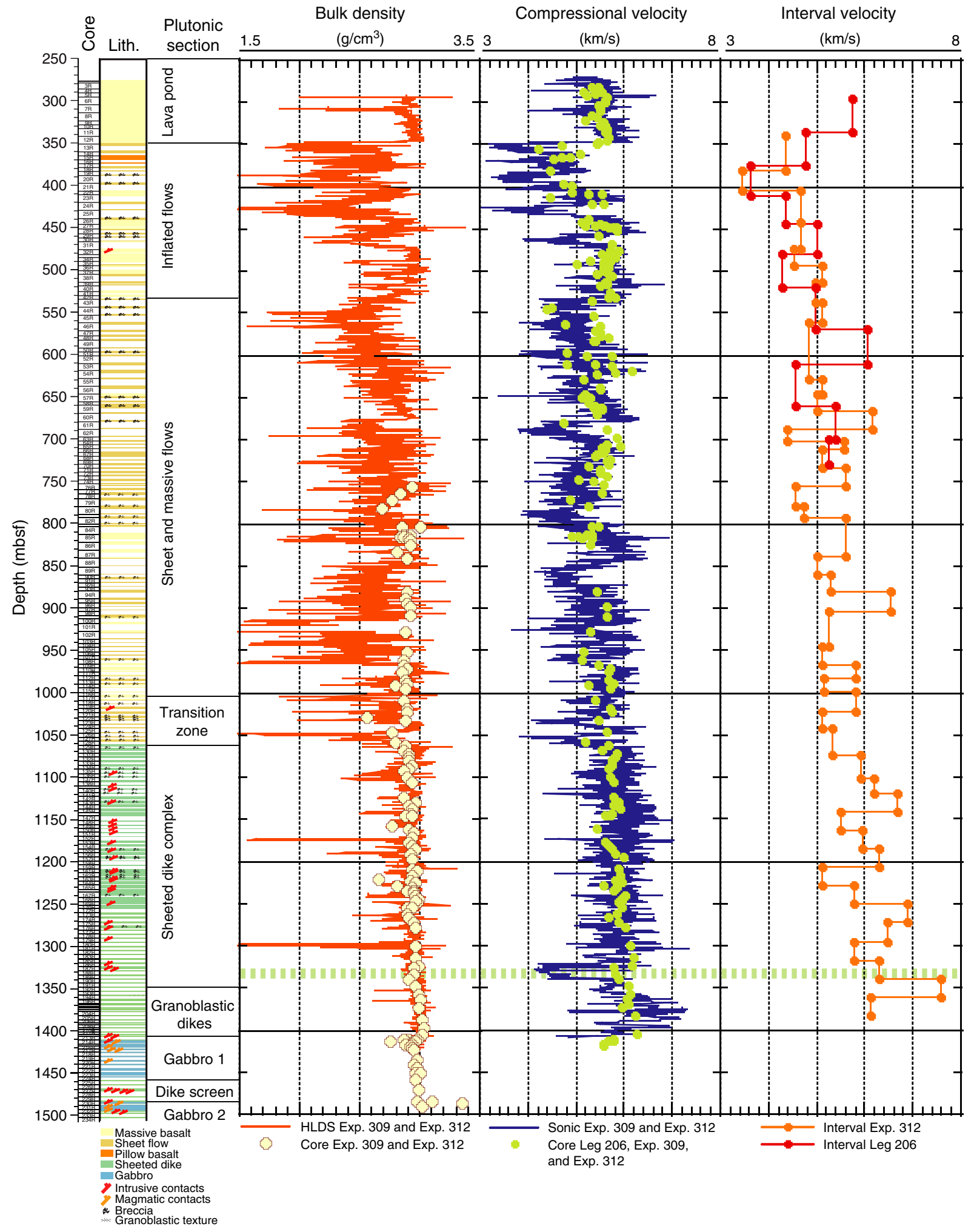


Figure F68. Whole-round image (left) and matching slab image. Fractures appear as sinusoids in the wholeround image and lines in the slab image. Preliminary Formation MicroScanner (FMS) image (right) has been depth-shifted $<10 \mathrm{~cm}$ to align fractures with the core images. Red numbers adjacent to the whole-round image and within the FMS image identify matching fractures. DMT = Deutsche Montan Technologie.

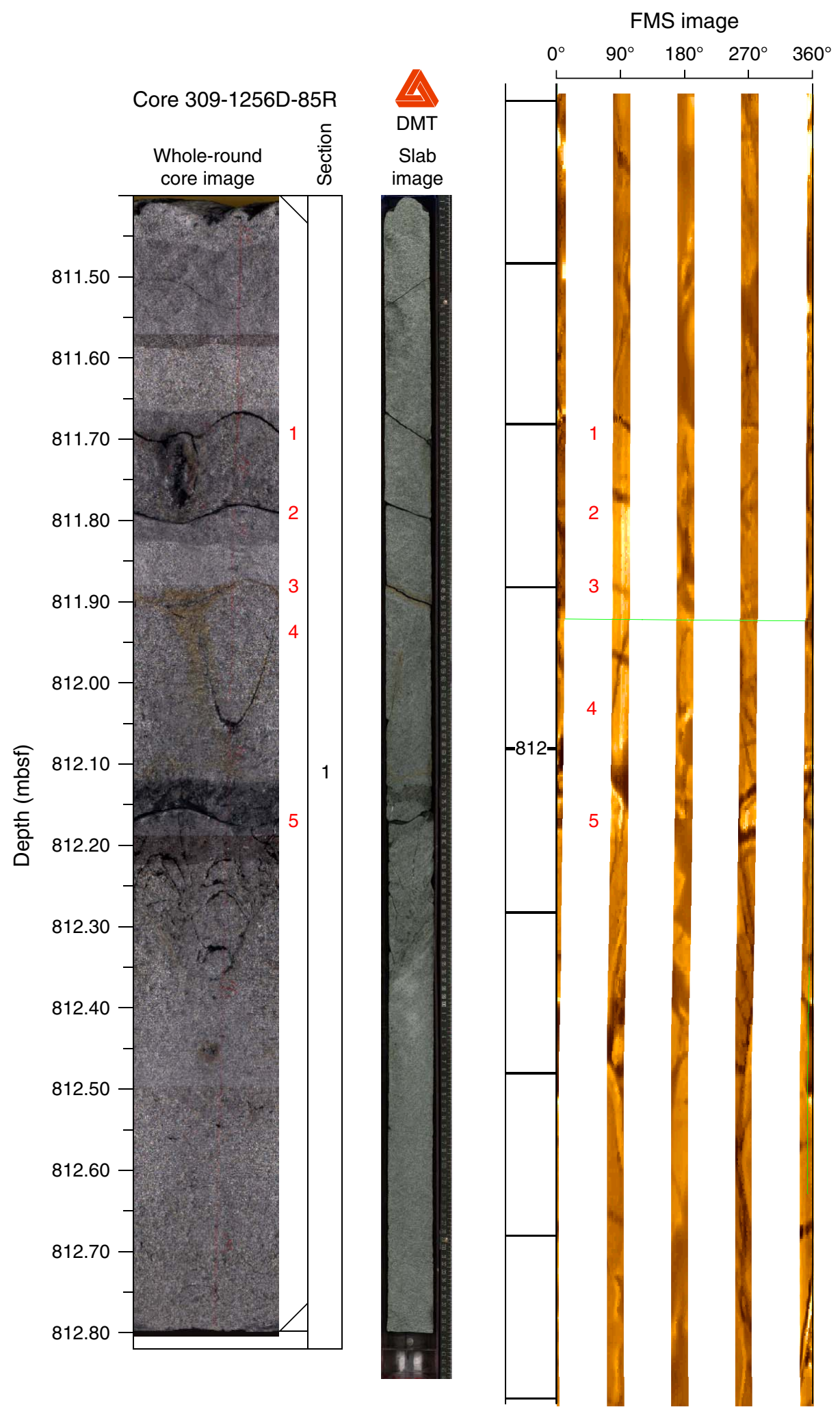


Figure F69. Bit sub under tension on the rotary table. Note the large crack that extends most of the way around the circumference.

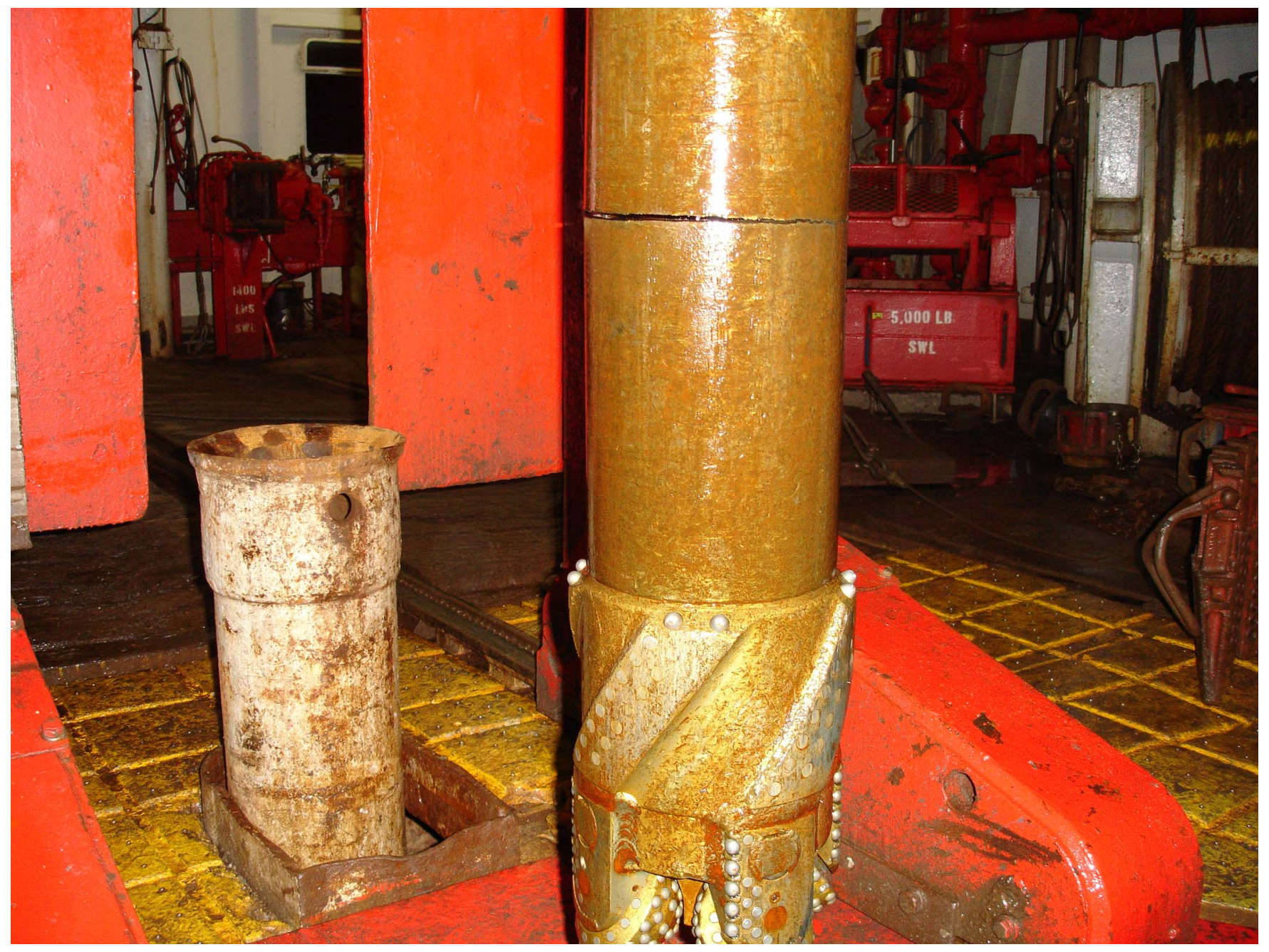


Figure F70. Crack found in the 5 inch drill pipe. The ends of the crack are splayed with curved edges while the central portion is planar.
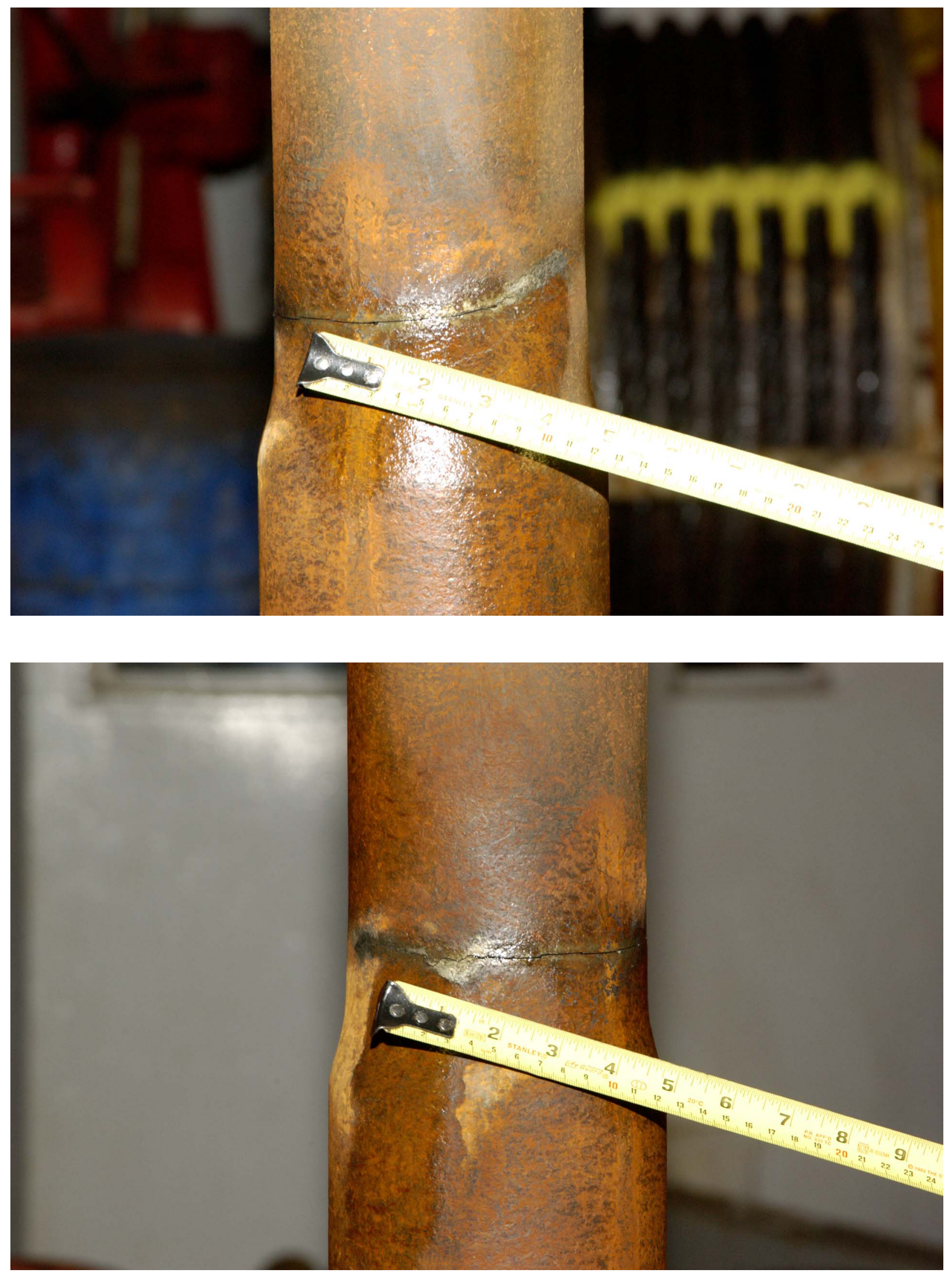
Figure F71. Used C-7 bit missing all of its cones. Note a small fragment of one cone remains. New C-7 bit shown for comparison.

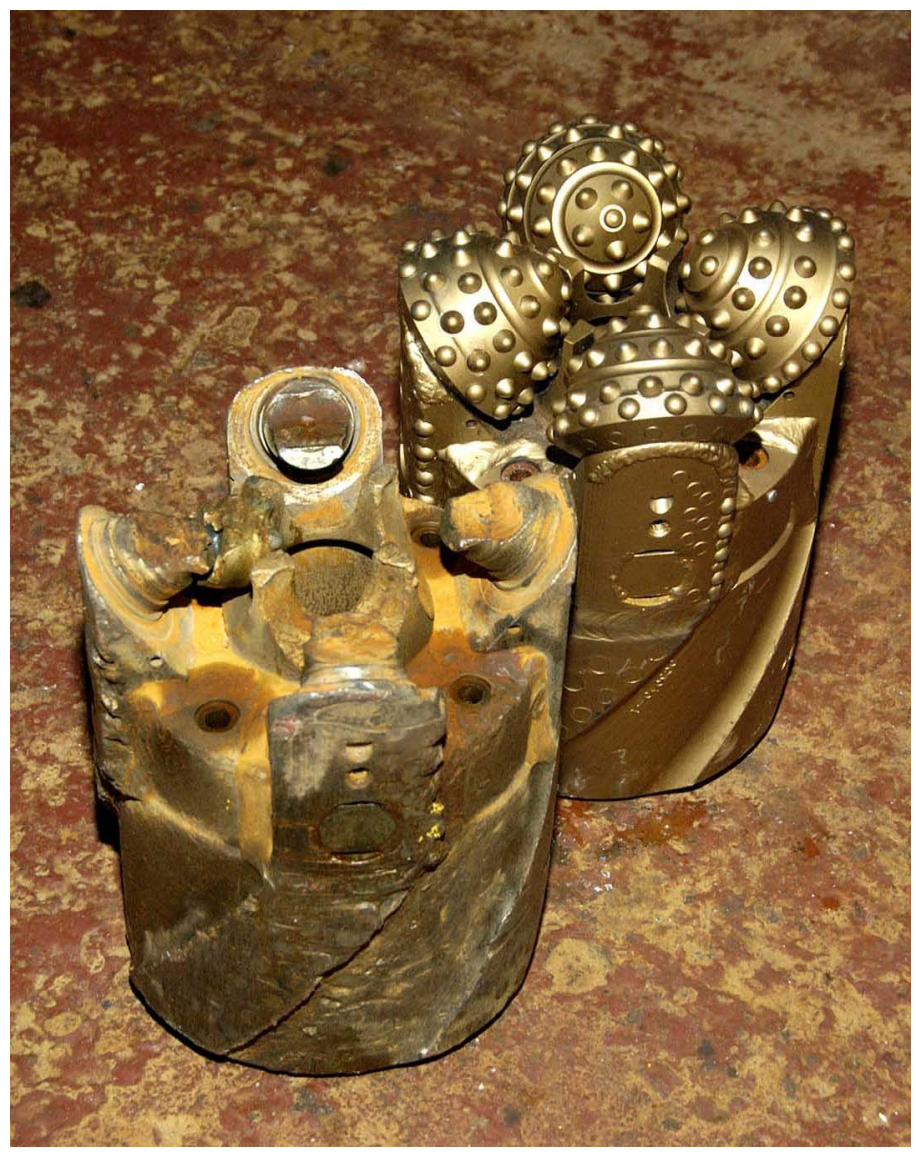


Movie M1. Video from the VIT showing the first reentry of Hole 1256D during Expedition 309. QuickTime software is available for Macintosh and Windows platforms only.

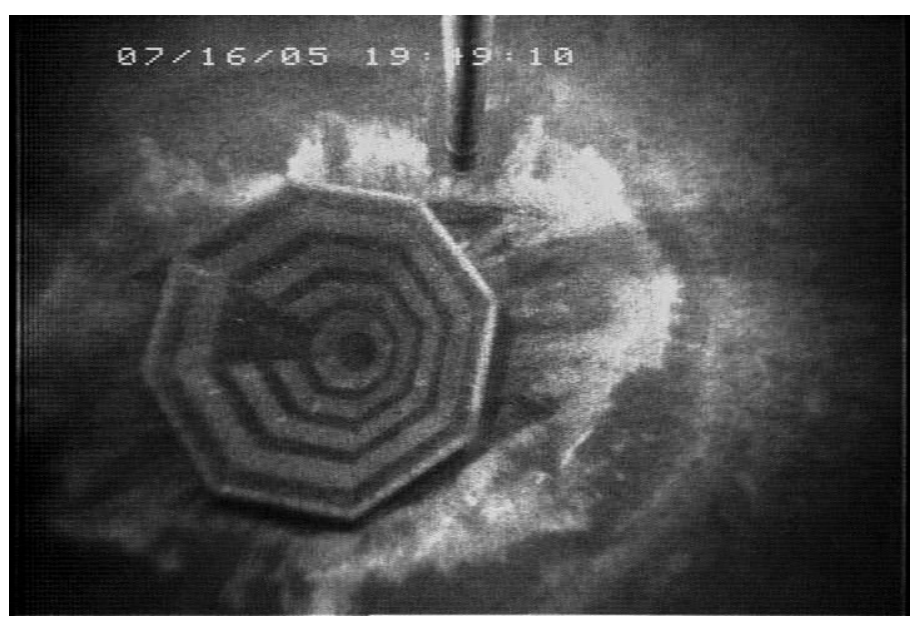


Movie M2. Video from the VIT showing vigorous jet of drilling mud exiting the 5 inch pipe from a crack.

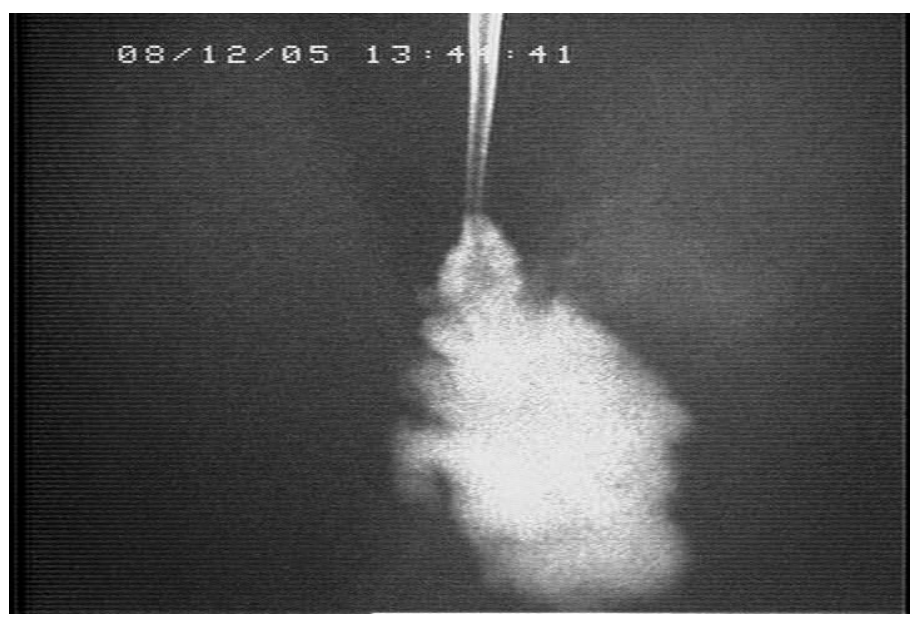


Movie M3. Video from the VIT showing the tenth reentry (ninth RCB coring bit) of Hole 1256D during Expedition 309.

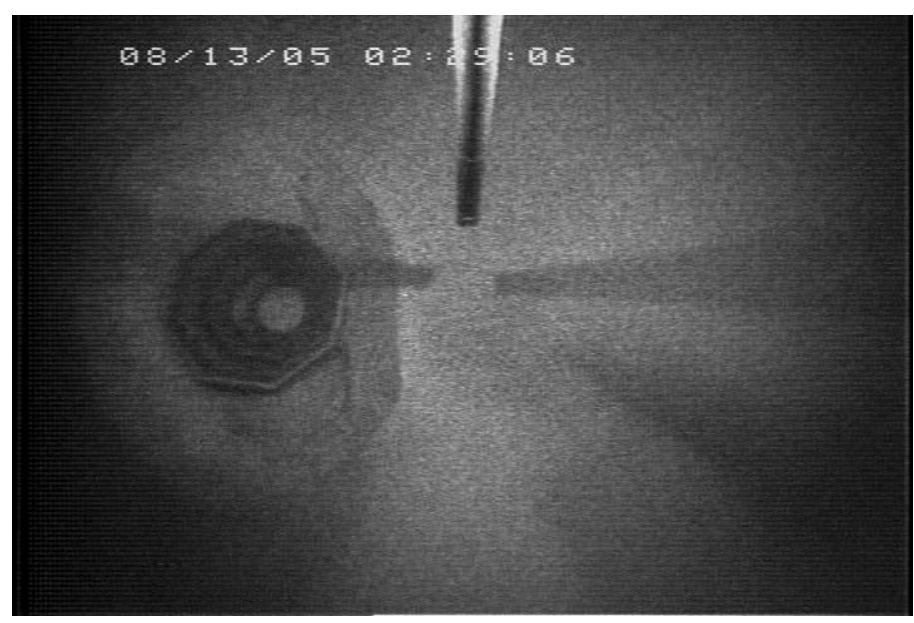


1. Drill an intact section of in situ upper ocean crust.

Current knowledge is based predominantly on exotic, tectonically exposed sections and suprasubduction zone ophiolites. These may not be representative of typical ocean crust, which comprises $60 \%$ of the Earth's surface.

2. Test the relationship between ocean ridge spreading rate and depth to the low-velocity zone (LVZ) and investigate the geological nature of the LVZ.

Assuming that the LVZ is a melt lens that crystallizes to gabbro, the observed spreading rate depth to the axial LVZ relationship msb at Site 1256, given a spreading rate of $220 \mathrm{~mm} / \mathrm{y}$.

3. Characterize the structure of superfast spreading rate crust, including

The lithology, thickness, structure, and geochemistry of the lavas and sheeted dikes and the nature of the lava-dike transition zone; and

The textures, chemistry, and magmatic structure of the upper

And, hence, determine the processes of crustal accretion (gabbro glacier vs. sheeted sills models).

4. Correlate lithology and rock properties with remote geophysical measurements, in particular:

What do seismic Layers 2 and 3 correspond to? (Generally assumed to be the dike/gabbro boundary, but it was intercepted with the sheeted dikes in Hole 504B, at an alteration boundary.)

Which crustal layers contribute to the marine magnetic anomalies?

5. Investigate the interactions between magmatic and alteration processes, including the nature and extent of water rock interaction, including

The alteration stratigraphy and chronology, fluid flow paths, and the nature of reaction/mixing zones;

The variability of thermal, fluid, and chemicalfluxes, the balance between low and high temperature alteration, and the implications for global geochemical budgets; and

The alteration of the dike-gabbro transition (the conductive boundary layer between the magma chamber and the hydrothermal system)
Complete penetration of the lavas and, for the first time in the history of scientific ocean drilling the sheeted dike complex.

Significant penetration $(>500 \mathrm{~m}$ ) of the upper gabbros.

The dike/gabbro boundary was drilled at $1157 \mathrm{msb}$ at Site 1256 , within the predicted LVZ depth range. This confirms: (1) the LVZ is a melt lens and (2) the spreading rate/LVZ depth relationship can be extrapolated to superfast spreading rates.

The dike/gabbro boundary drilled for the first time in in situ norma ocean crust.

Complete penetration of the lavas and dikes, allowing comparison with Hole 504B crust.

pper $\sim 100 \mathrm{~m}$ of plutonics recovered (gabbro, oxide gabbro, quartz-rich oxide diorites, and trondjhemite dikelets, with dike screens and stoped dike clasts).

The upper gabbros have chilled upper and lower contacts and are on average slightly more primitive than the dikes and lavas, but they representative of the entire loy are not cu

Dike/gabbro boundary intercepted within L2 at Site 1256 . Here the dike/gabbro boundary is not the L2/L3 boundary or an alteration boundary within the dikes.

Alteration of the lavas, dikes, upper gabbros, and transition zones described and compared to Hole 504B and ophiolites. A contac metamorphism zone was discovered in the lower dikes, due to intrusion of the upper gabbro, which was altered by high temperature fluids.
No outstanding goals.

Evidence of upper gabbros with chilled upper and lower contacts favors the sheeted-sill model. However, given that the gabbros are fractionated (requiring a deeper magma chamber) and tha $100 \mathrm{~m}$ represents only $\sim 2 \%$ of the gabbro, further drilling is

Intercept the Layer 2/3 boundary at Site 1256 and determine its geological nature.

Sample a longer, more representative gabbro section, determine the magnetic properties of the gabbros, and complete the crusta "magnetic budget."

Sample the entire hydrothermally altered portion of the crust to complete the crustal geochemical budgets.

Determine the depth of hydrothermal fluid penetration and temperatures of interactions as this influences processes of crustal accretion and heat removal from the lower crust (significant to global heat output). 
Table T2. Predicted depths to gabbros, Site 1256.

\begin{tabular}{|c|c|c|c|c|c|c|}
\hline \multirow[b]{2}{*}{ Measurement } & \multicolumn{2}{|c|}{$\begin{array}{c}\text { Depth to axial } \\
\text { low-velocity zone }\end{array}$} & \multicolumn{2}{|c|}{$\begin{array}{c}100 \mathrm{~m} \text { of off-axis } \\
\text { lavas }\end{array}$} & \multicolumn{2}{|c|}{$\begin{array}{c}300 \mathrm{~m} \text { of off-axis } \\
\text { lavas }\end{array}$} \\
\hline & (msb) & (mbsf) & (msb) & (mbsf) & (msb) & (mbsf) \\
\hline & 725 & 975 & 825 & 1075 & 1025 & 1275 \\
\hline Maximum & 1000 & 1250 & 1100 & 1350 & 1300 & 1550 \\
\hline
\end{tabular}

Notes: Depths to the axial low-velocity zone estimated from the relationship with spreading rate (following Purdy et al., 1992, and Carbotte et al., 1997b) for ocean crust spreading at $200 \mathrm{~mm} / \mathrm{y}$. Depth in mbsf includes the $250 \mathrm{~m}$ thick sediment cover at Site 1256.

Table T3. Rates of recovery and penetration, Hole 1256D.

\begin{tabular}{lccc}
\hline \multicolumn{1}{c}{ Interval } & $\begin{array}{c}\text { Cored interval } \\
(\mathrm{m})\end{array}$ & $\begin{array}{c}\text { Average recovery } \\
(\%)\end{array}$ & $\begin{array}{c}\text { Average ROP } \\
(\mathrm{m} / \mathrm{h})\end{array}$ \\
\hline Cores 206-1256D-2R through 312-1256D-234R & 1231 & 37 & 1.2 \\
Lavas and transition zone (Cores 206-1256D-2R through 309-1256D-128R) & 785 & 41 & 1.5 \\
Upper dikes (Cores 309-1256D-129R through 312-1256D-191R) & 287 & 37 & 0.9 \\
Granoblastic dikes (Cores 312-1256D-192R through 213R) & 63 & 7 & 0.5 \\
Plutonic section (Cores 312-1256D-214R through 234R) & 96 & 29 & 1.1 \\
Gabbros (Cores 312-1256D-214R through 224R and 230R through 234R) & 72 & 35 & 1.2 \\
\hline
\end{tabular}

Note: $\mathrm{ROP}=$ rate of penetration. 
Table T4. Key parameters for Hole 1256D and preliminary subdivisions of the upper oceanic crust at Site 1256 adopted for Expeditions 309 and 312.

Location: $6^{\circ} 44.163^{\prime} \mathrm{N}, 91^{\circ} 56.061^{\prime} \mathrm{W}$

Water depth $(\mathrm{m}): 3634.7$

Sediment thickness (m): 250

16 inch casing string $(\mathrm{m}): 269.5$

16 inch casing string $(\mathrm{m}): 269.5$
Interval in Hole $1256 \mathrm{D}$ drilled during

ODP Leg 206: 752 mbsf, $502 \mathrm{msb}$

IODP Expedition 309: 1255.1 mbsf, $1005.1 \mathrm{msb}$

IODP Expedition 312: 1507.1 mbsf, 1257.1 msb

\begin{tabular}{|c|c|c|c|c|c|}
\hline $\begin{array}{l}\text { Major lithologic } \\
\text { zone }\end{array}$ & Sublithology & $\begin{array}{l}\text { Top core, section, } \\
\text { piece, interval }(\mathrm{cm})\end{array}$ & Top igneous unit & $\begin{array}{l}\text { Depth } \\
\text { (mbsf) }\end{array}$ & Criteria \\
\hline \multirow{3}{*}{ Lavas } & Lava pond & $\begin{array}{l}\text { 206-1256D-2R-1 } \\
(\text { Piece } 1,0)\end{array}$ & $\begin{array}{l}1256 \mathrm{D}-1 \\
(1256 \mathrm{C}-1 \text { through } 18)\end{array}$ & $\sim 250$ & Massive ponded lava including overlying sheet flows. \\
\hline & Inflated flows & $\begin{array}{l}\text { 206-1256D-13R-1 } \\
(\text { Piece } 1,0)\end{array}$ & $1256 \mathrm{D}-2$ & 350.3 & Massive sheet and pillowed flows with rare inflation features. \\
\hline & Sheet and massive flows & $\begin{array}{l}\text { 206-1256D-43R-1 } \\
(\text { Piece } 1,0)\end{array}$ & $1256 \mathrm{D}-16$ & 533.9 & Sheet flows with subordinate massive flows. \\
\hline Transition zone & & $\begin{array}{l}\text { 309-1256D-117R-1 } \\
\text { (Piece 6, 85) }\end{array}$ & $1256 \mathrm{D}-40$ & 1004.1 & Sheet flows with breccias, rare dikes, and alteration at (sub-) greenschist facies conditions. \\
\hline \multirow{2}{*}{$\begin{array}{l}\text { Sheeted dike } \\
\text { complex }\end{array}$} & Upper dikes & $\begin{array}{l}\text { 309-1256D-129R-1 } \\
\text { (Piece } 1,0)\end{array}$ & $1256 \mathrm{D}-44 a$ & 1060.9 & Massive basalts, common subvertical intrusive contacts. Elevated $V_{P}$ and TC. \\
\hline & Granoblastic dikes & $\begin{array}{l}\text { 312-1256D-192R-1 } \\
\text { (Piece } 1,0)\end{array}$ & $1256 \mathrm{D}-78$ & 1348.3 & $\begin{array}{l}\text { Granoblastic texture; equant grains; secondary clinopyroxene, orthopyroxene, plagioclase, hornblende, } \\
\text { magnetite, and illite. }\end{array}$ \\
\hline \multirow[b]{3}{*}{ Plutonic section } & Gabbro 1 & $\begin{array}{l}\text { 312-1256D-213R-1 } \\
\text { (Piece 13, 52) }\end{array}$ & $1256 \mathrm{D}-81$ & 1406.6 & $\begin{array}{l}\text { Medium-grained gabbroic rocks intrude overlying dikes: gabbro, disseminated oxide gabbro, patchy gabbro, } \\
\text { and quartz-rich oxide diorite. }\end{array}$ \\
\hline & Dike screen & $\begin{array}{l}\text { 312-1256D-225R-1 } \\
\text { (Piece } 1,0)\end{array}$ & $1256 \mathrm{D}-90$ & 1458.9 & $\begin{array}{l}\text { Fine-grained to cryptocrystalline basalt dike. Highly altered, granoblastic texture, secondary clinopyroxene, } \\
\text { orthopyroxene, plagioclase, magnetite, ilmenite, and hornblende. }\end{array}$ \\
\hline & Gabbro 2 & $\begin{array}{l}\text { 312-1256D-230R-1 } \\
\text { (Piece } 5,15)\end{array}$ & 1256D-91 & 1483.1 & $\begin{array}{l}\text { Plutonic rock intrudes upper and lower dike screens; medium-grained gabbro, oxide-bearing quartz gabbro, } \\
\text { oxide gabbro, orthopyroxene-bearing gabbro, trondjhemite; leucocratic-gabbro; all highly altered; stoped } \\
\text { basalt. } \\
\text { Gabbronorite of uncertain origin. } \\
\text { Late dike Unit 1256D-95 at } 1502.6 \text { mbsf. }\end{array}$ \\
\hline
\end{tabular}

Note: $\mathrm{TC}=$ thermal conductivity. 
Table T5. Vertical seismic profile experiment in Hole 1256D, Expedition 312.

\begin{tabular}{|c|c|c|c|}
\hline $\begin{array}{l}\text { Station } \\
\text { number }\end{array}$ & $\begin{array}{l}\text { Depth } \\
\text { (mbsf) }\end{array}$ & $\begin{array}{l}\text { Two-way } \\
\text { traveltime } \\
\quad(\mathrm{ms})\end{array}$ & $\begin{array}{c}\text { Interva } \\
\text { velocity } \\
(\mathrm{km} / \mathrm{s})\end{array}$ \\
\hline 60 & 339 & 2594.6 & 4.362 \\
\hline 59 & 380 & 2604 & 3.464 \\
\hline 58 & 404 & 2610.9 & 4.673 \\
\hline 57 & 443 & - & - \\
\hline 56 & 444 & - & - \\
\hline 55 & 474 & 2625.9 & 4.545 \\
\hline 54 & 494 & 2630.3 & 5.128 \\
\hline 53 & 514 & 2634.2 & 4.979 \\
\hline 52 & 538 & 2639 & 5.106 \\
\hline 51 & 562 & 2643.7 & 4.827 \\
\hline 50 & 587 & - & - \\
\hline 49 & 610 & - & - \\
\hline 47 & 629 & 2657.6 & 5.114 \\
\hline 46 & 630 & - & - \\
\hline 45 & 647 & 2661.1 & 5.026 \\
\hline 44 & 666 & 2664.9 & 6.176 \\
\hline 43 & 667 & - & - \\
\hline 42 & 687 & 2668.3 & 4.406 \\
\hline 41 & 701 & 2671.5 & 5.556 \\
\hline 40 & 711 & 2673.3 & 5.116 \\
\hline 39 & 733 & 2677.6 & 5.61 \\
\hline 38 & 756 & 2681.7 & 4.562 \\
\hline 37 & 778 & 2686.5 & 4.719 \\
\hline 36 & 793 & 2689.7 & 5.598 \\
\hline 35 & 811 & - & - \\
\hline 34 & 812 & - & - \\
\hline 33 & 839 & 2697.9 & 5.023 \\
\hline 32 & 861 & 2702.3 & 5.278 \\
\hline 31 & 862 & - & - \\
\hline 30 & 880 & 2705.9 & 6.543 \\
\hline 29 & 881 & - & - \\
\hline 28 & 903 & 2709.4 & 5.244 \\
\hline 27 & 934 & - & - \\
\hline 26 & 946 & 2717.6 & 5.122 \\
\hline 25 & 967 & 2721.7 & 5.808 \\
\hline 24 & 982 & 2724.3 & 5.161 \\
\hline 23 & 987 & - & - \\
\hline 22 & 998 & 2727.4 & 5.814 \\
\hline 21 & 1000 & - & - \\
\hline 20 & 1023 & 2731.7 & 5.128 \\
\hline 19 & 1031 & - & - \\
\hline 18 & 1043 & 2735.6 & 5.333 \\
\hline 17 & 1054 & - & - \\
\hline 16 & 1075 & 2741.6 & 5.909 \\
\hline 15 & 1101 & 2746 & 6.207 \\
\hline 14 & 1119 & 2748.9 & 6.667 \\
\hline 13 & 1141 & 2752.2 & 5.5 \\
\hline 12 & 1163 & 2756.2 & 5.946 \\
\hline 11 & 1185 & 2759.9 & 6.286 \\
\hline 10 & 1207 & 2763.4 & 5.116 \\
\hline 9 & 1229 & 2767.7 & 5.789 \\
\hline 8 & 1251 & 2771.5 & 6.875 \\
\hline 7 & 1273 & 2774.7 & 6.47 \\
\hline 6 & 1295 & 2778.1 & 5.789 \\
\hline 5 & 1317 & 2781.9 & 6.286 \\
\hline 4 & 1339 & 2785.4 & 7.586 \\
\hline 3 & 1361 & 2788.3 & 6.111 \\
\hline 2 & 1383 & 2791.9 & - \\
\hline 1 & 1382 & - & - \\
\hline
\end{tabular}

Notes: Traveltimes are averages of 11 to 25 shots at each clamping depth. $-=$ no value obtained. 
Table T6. Operations conducted in Hole 1256D, Expedition 309. (See table notes. Continued on next page.)

\begin{tabular}{|c|c|c|c|c|c|c|}
\hline \multirow[b]{2}{*}{ Operation in Hole 1256D } & \multirow[b]{2}{*}{$\begin{array}{l}\text { Local time } \\
\text { (h) }\end{array}$} & \multirow[b]{2}{*}{$\begin{array}{l}\text { Date } \\
(2005)\end{array}$} & \multicolumn{3}{|c|}{ Time } & \multirow[b]{2}{*}{ Comments } \\
\hline & & & $\begin{array}{l}\text { On hole } \\
\text { (h) }\end{array}$ & $\begin{array}{l}\text { On site } \\
\text { (h) }\end{array}$ & $\begin{array}{l}\text { On site } \\
\text { (days) }\end{array}$ & \\
\hline Arrive on site, lower all thrusters & 1030 & $16 \mathrm{Jul}$ & & & & \\
\hline Reentry number 1 & 1945 & $16 \mathrm{Jul}$ & 9.25 & 9.25 & 0.39 & \\
\hline Begin WSTP run & 0030 & $17 \mathrm{Jul}$ & 4.75 & 14.00 & 0.58 & \\
\hline End WSTP & 0430 & $17 \mathrm{Jul}$ & 4.00 & 18.00 & 0.75 & \\
\hline Begin APCT run & 0430 & $17 \mathrm{Jul}$ & 0.00 & 18.00 & 0.75 & \\
\hline End APCT run & 0630 & $17 \mathrm{Jul}$ & 2.00 & 20.00 & 0.83 & \\
\hline Begin second WSTP run & 0630 & $17 \mathrm{Jul}$ & 0.00 & 20.00 & 0.83 & \\
\hline End second WSTP run & 0830 & $17 \mathrm{Jul}$ & 2.00 & 22.00 & 0.92 & \\
\hline Rig up logging equipment & 1015 & $17 \mathrm{Jul}$ & 1.75 & 23.75 & 0.99 & \\
\hline End triple combo & 2045 & $17 \mathrm{Jul}$ & 10.50 & 34.25 & 1.43 & \\
\hline End FMS & 0530 & $18 \mathrm{Jul}$ & 8.75 & 43.00 & 1.79 & Clear seafloor at $0615 \mathrm{~h}$ on 18 July \\
\hline Clear cone & 0615 & $18 \mathrm{Jul}$ & 0.75 & 43.75 & 1.82 & \\
\hline Deploy RCB bit number 1 & 1500 & $18 \mathrm{Jul}$ & 8.75 & 52.50 & 2.19 & \\
\hline Reentry number 2 & 2325 & $18 \mathrm{Jul}$ & 8.42 & 60.92 & 2.54 & \\
\hline Begin coring with bit number 1 & 1200 & 19 Jul & 12.58 & 73.50 & 3.06 & \\
\hline End coring with bit number 1 & 0145 & $22 \mathrm{Jul}$ & 61.75 & 135.25 & 5.64 & Clear seafloor at $0410 \mathrm{~h}$ on 22 July \\
\hline Bit number 1 on deck & 1000 & $22 \mathrm{Jul}$ & 8.25 & 143.50 & 5.98 & \\
\hline Deploy bit number 2 & 1200 & $22 \mathrm{Jul}$ & 2.00 & 145.50 & 6.06 & \\
\hline Start-slip and cut drilling line & 1645 & $22 \mathrm{Jul}$ & 4.75 & 150.25 & 6.26 & \\
\hline End-slip and cut drilling line & 1745 & $22 \mathrm{Jul}$ & 1.00 & 151.25 & 6.30 & \\
\hline Reentry number 3 & 1911 & $22 \mathrm{Jul}$ & 1.43 & 152.68 & 6.36 & \\
\hline Begin coring with bit number 2 & 2230 & $22 \mathrm{Jul}$ & 3.32 & 156.00 & 6.50 & \\
\hline End coring with bit number 2 & 0010 & $26 \mathrm{Jul}$ & 73.67 & 229.67 & 9.57 & Clear seafloor at $0300 \mathrm{~h}$ on 26 July \\
\hline Bit number 2 on deck & 0830 & $26 \mathrm{Jul}$ & 8.33 & 238.00 & 9.92 & \\
\hline Deploy bit number 3 & 1000 & $26 \mathrm{Jul}$ & 1.50 & 239.50 & 9.98 & \\
\hline Reentry number 4 & 1610 & $26 \mathrm{Jul}$ & 6.17 & 245.67 & 10.24 & \\
\hline Begin coring with bit number 3 & 2045 & $26 \mathrm{Jul}$ & 4.58 & 250.25 & 10.43 & \\
\hline End coring with bit number 3 & 1530 & 29 Jul & 66.75 & 317.00 & 13.21 & Clear seafloor at $1800 \mathrm{~h}$ on 29 July \\
\hline Bit number 3 on deck & 0000 & $30 \mathrm{Jul}$ & 8.50 & 325.50 & 13.56 & \\
\hline Deploy bit number 4 & 0000 & $30 \mathrm{Jul}$ & 0.00 & 325.50 & 13.56 & \\
\hline WSTP sample & 1000 & $30 \mathrm{Jul}$ & 10.00 & 335.50 & 13.98 & \\
\hline Reentry number 5 & 1015 & $30 \mathrm{jul}$ & 0.25 & 335.75 & 13.99 & \\
\hline Begin coring with bit number 4 & 1445 & $30 \mathrm{Jul}$ & 4.50 & 340.25 & 14.18 & Cracked bit sub \\
\hline End coring with bit number 4 & 1745 & $31 \mathrm{Jul}$ & 27.00 & 367.25 & 15.30 & Clear seafloor at $2215 \mathrm{~h}$ on 31 July \\
\hline Bit number 4 on deck & 0300 & 1 Aug & 9.25 & 376.50 & 15.69 & \\
\hline Deploy bit number 5 & 0630 & 1 Aug & 3.50 & 380.00 & 15.83 & \\
\hline Reentry number 6 & 1415 & 1 Aug & 7.75 & 387.75 & 16.16 & \\
\hline Start-slip and cut drilling line & 1430 & 1 Aug & 0.25 & 388.00 & 16.17 & \\
\hline End-slip and cut drilling line & 1530 & 1 Aug & 1.00 & 389.00 & 16.21 & \\
\hline Begin coring with bit number 5 & 1945 & 1 Aug & 4.25 & 393.25 & 16.39 & \\
\hline End coring with bit number 5 & 1845 & 4 Aug & 71.00 & 464.25 & 19.34 & Clear seafloor at $2115 \mathrm{~h}$ on $4 \mathrm{Aug}$ \\
\hline Bit number 5 on deck & 0200 & 5 Aug & 7.25 & 471.50 & 19.65 & \\
\hline Deploy bit number 6 & 0215 & 5 Aug & 0.25 & 471.75 & 19.66 & \\
\hline Reentry number 7 & 0951 & 5 Aug & 7.60 & 479.35 & 19.97 & \\
\hline Begin coring with bit number 6 & 1430 & 5 Aug & 4.65 & 484.00 & 20.17 & \\
\hline End coring with bit number 6 & 0930 & 8 Aug & 67.00 & 551.00 & 22.96 & Clear seafloor at $0400 \mathrm{~h}$ on $8 \mathrm{Aug}$ \\
\hline Bit number 6 on deck & 1800 & 8 Aug & 8.50 & 559.50 & 23.31 & \\
\hline Deploy bit number 7 & 1815 & 8 Aug & 0.25 & 559.75 & 23.32 & \\
\hline Reentry number 8 & 0145 & 9 Aug & 7.50 & 567.25 & 23.64 & \\
\hline Begin coring with bit number 7 & 0815 & 9 Aug & 6.50 & 573.75 & 23.91 & \\
\hline End coring with bit number 7 & 1415 & 11 Aug & 54.00 & 627.75 & 26.16 & Clear seafloor at $1350 \mathrm{~h}$ on $12 \mathrm{Aug}$ \\
\hline NDT inspect DC & 0405 & 12 Aug & 13.83 & 641.58 & 26.73 & \\
\hline Bit number 7 on deck & 0415 & 12 Aug & 0.17 & 641.75 & 26.74 & \\
\hline Deploy bit number 8 & 0415 & 12 Aug & 0.00 & 641.75 & 26.74 & \\
\hline Check drill string for cracks & 1345 & 12 Aug & 9.50 & 651.25 & 27.14 & \\
\hline Change out 2 stands 5 inch drill pipe & 2030 & 12 Aug & 6.75 & 658.00 & 27.42 & \\
\hline Reentry number 9 & 0230 & 13 Aug & 6.00 & 664.00 & 27.67 & \\
\hline Begin coring with bit number 8 & 0730 & 13 Aug & 5.00 & 669.00 & 27.88 & \\
\hline End coring with bit number 8 & 1045 & 16 Aug & 75.25 & 744.25 & 31.01 & Clear seafloor at $1340 \mathrm{~h}$ on $16 \mathrm{Aug}$ \\
\hline Bit number 8 on deck & 1945 & 16 Aug & 9.00 & 753.25 & 31.39 & \\
\hline Deploy bit number 9 & 2000 & 16 Aug & 0.25 & 753.50 & 31.40 & \\
\hline Reentry number 10 & 0340 & 17 Aug & 7.67 & 761.17 & 31.72 & \\
\hline Begin coring with bit number 9 & 0730 & 17 Aug & 3.83 & 765.00 & 31.88 & \\
\hline End coring with bit number 9 & 1040 & 20 Aug & 75.17 & 840.17 & 35.01 & \\
\hline Begin wiper trip & 1040 & 20 Aug & 0.00 & 840.17 & 35.01 & \\
\hline End wiper trip & 1800 & 20 Aug & 7.33 & 847.50 & 35.31 & Clear seafloor at $1640 \mathrm{~h}$ on $20 \mathrm{Aug}$ \\
\hline Bit number 9 on deck & 0200 & 21 Aug & 8.00 & 855.50 & 35.65 & \\
\hline Make up/Deploy logging BHA & 0200 & 21 Aug & 0.00 & 855.50 & 35.65 & \\
\hline
\end{tabular}


Table T6 (continued).

\begin{tabular}{|c|c|c|c|c|c|c|}
\hline \multirow[b]{2}{*}{ Operation in Hole 1256D } & \multirow[b]{2}{*}{$\begin{array}{l}\text { Local time } \\
\text { (h) }\end{array}$} & \multirow[b]{2}{*}{$\begin{array}{c}\text { Date } \\
(2005)\end{array}$} & \multicolumn{3}{|c|}{ Time } & \multirow[b]{2}{*}{ Comments } \\
\hline & & & $\begin{array}{l}\text { On hole } \\
\text { (h) }\end{array}$ & $\begin{array}{l}\text { On site } \\
\text { (h) }\end{array}$ & $\begin{array}{l}\text { On site } \\
\text { (days) }\end{array}$ & \\
\hline Reentry number 11 & 0800 & 21 Aug & 6.00 & 861.50 & 35.90 & \\
\hline Run in hole to casing shoe & 0830 & 21 Aug & 0.50 & 862.00 & 35.92 & \\
\hline Rig up logging equipment & 1200 & 21 Aug & 3.50 & 865.50 & 36.06 & \\
\hline Triple combo completed & 2315 & 21 Aug & 11.25 & 876.75 & 36.53 & Not able to get WST downhole \\
\hline FMS-sonic completed & 1100 & 22 Aug & 11.75 & 888.50 & 37.02 & \\
\hline UBI experiment completed & 0400 & 23 Aug & 17.00 & 905.50 & 37.73 & Clear seafloor at $0600 \mathrm{~h}$ on $24 \mathrm{Aug}$ \\
\hline WST experiment completed & 1315 & 23 Aug & 9.25 & 914.75 & 38.11 & \\
\hline FMS-sonic completed & 0500 & 24 Aug & 15.75 & 930.50 & 38.77 & \\
\hline Beacon recovered & 1200 & 24 Aug & 7.00 & 937.50 & 39.06 & \\
\hline Rig for departure & 1300 & 24 Aug & 1.00 & 938.50 & 39.10 & Beacon recovered after 39 days \\
\hline Depart location & 1300 & 24 Aug & 0.00 & 938.50 & 39.10 & \\
\hline
\end{tabular}

Notes: WSTP $=$ Water Sampling Temperature Probe, APCT = Advanced Piston Corer Temperature tool, FMS = Formation MicroScanner, $\mathrm{RCB}=$ Rotary Core Barrel, NDT = nondestructive testing, DC = drill collar, BHA = bottom-hole assembly, WST = Well Seismic Tool, UBI = Ultrasonic Borehole Imager.

Table T7. Summary of coring bits used during Expedition 309.

\begin{tabular}{|c|c|c|c|c|c|c|c|c|c|c|}
\hline Bit & Manufacturer & $\begin{array}{c}\text { Serial } \\
\text { number }\end{array}$ & Bit type & Size & $\begin{array}{l}\text { Number } \\
\text { of cores }\end{array}$ & $\begin{array}{l}\text { Cored } \\
\text { interval } \\
(\mathrm{m})\end{array}$ & $\begin{array}{l}\text { Core } \\
\text { recovered } \\
(\mathrm{m})\end{array}$ & $\begin{array}{l}\text { Recovery } \\
\text { (\%) }\end{array}$ & $\begin{array}{l}\text { Coring } \\
\text { time }(\mathrm{h})\end{array}$ & $\begin{array}{l}\text { Rate of } \\
\text { penetration } \\
(\mathrm{m} / \mathrm{h})\end{array}$ \\
\hline Log bit & & & & & Logging & & & & 43.8 & \\
\hline 1256D-1 & RBI & BF-739 & C-9 & $97 / 8$ & 11 & 69.1 & 25.20 & 36.5 & 51.7 & 1.34 \\
\hline 1256D-2 & $\mathrm{RBI}$ & BF-852 & C-9 & $97 / 8$ & 11 & 76.8 & 18.02 & 23.5 & 52.1 & 1.47 \\
\hline $1256 \mathrm{D}-3$ & RBI & BF-854 & C-9 & $97 / 8$ & 11 & 61.1 & 14.85 & 24.3 & 52.8 & 1.16 \\
\hline 1256D-4 & $\mathrm{RBI}$ & BF-856 & C-9 & $97 / 8$ & 4 & 20.4 & 9.52 & 46.7 & 17.8 & 1.14 \\
\hline $1256 \mathrm{D}-5$ & RBI & BF-858 & C-9 & $97 / 8$ & 15 & 72.1 & 20.56 & 28.5 & 50.1 & 1.44 \\
\hline 1256D-6 & RBI & BF-741 & C-9 & $97 / 8$ & 12 & 57.6 & 21.45 & 37.2 & 50.8 & 1.13 \\
\hline 1256D-7 & $\mathrm{RBI}$ & BF-742 & C-9 & $97 / 8$ & 8 & 36.3 & 17.70 & 48.8 & 42.5 & 0.85 \\
\hline 1256D-8 & RBI & BF-853 & C-9 & $97 / 8$ & 12 & 58.6 & 17.74 & 30.3 & 57.8 & 1.01 \\
\hline 1256D-9 & $\mathrm{RBI}$ & CL-540 & C-9 & $97 / 8$ & 12 & 51.3 & 37.57 & 73.2 & 53.1 & 0.97 \\
\hline \multirow[t]{2}{*}{ Log bit } & & & & & Logging & & & & 76.0 & \\
\hline & & & & Totals: & 96 & 503.3 & 182.61 & & & 1.17 \\
\hline
\end{tabular}

Note: $\mathrm{RBI}=$ Rock Bit International. 
Table T8. Operations summary, Expedition 312.

\begin{tabular}{|c|c|c|c|c|c|c|c|c|c|c|}
\hline Hole & Latitude & Longitude & $\begin{array}{l}\text { Number } \\
\text { of cores }\end{array}$ & $\begin{array}{c}\text { Interval } \\
\text { cored (m) }\end{array}$ & $\begin{array}{l}\text { Core } \\
\text { recovered } \\
\text { (m) }\end{array}$ & $\begin{array}{c}\text { Recovery } \\
(\%)\end{array}$ & $\begin{array}{c}\text { Drilled/ } \\
\text { Washed } \\
\text { (m) }\end{array}$ & $\begin{array}{c}\text { Total } \\
\text { penetration } \\
\text { (m) }\end{array}$ & $\begin{array}{l}\text { Time on } \\
\text { hole }(\mathrm{h})\end{array}$ & $\begin{array}{c}\text { Time on } \\
\text { hole } \\
\text { (days) }\end{array}$ \\
\hline $1256 \mathrm{D}-1$ & $6^{\circ} 44.1631^{\prime} \mathrm{N}$ & $91^{\circ} 56.0612^{\prime} \mathrm{W}$ & 0 & 0.00 & 0.00 & 0.0 & 0.00 & 0.00 & 61.50 & 2.6 \\
\hline $1256 \mathrm{D}-\mathrm{T}$ & $6^{\circ} 44.1631^{\prime} \mathrm{N}$ & $91^{\circ} 56.0612^{\prime} \mathrm{W}$ & 0 & \multicolumn{5}{|c|}{ Drill ahead with $97 / 8$ inch tricone bit to bottom } & 63.25 & 2.6 \\
\hline $1256 \mathrm{D}-2$ & $6^{\circ} 44.1631^{\prime} \mathrm{N}$ & $91^{\circ} 56.0612^{\prime} \mathrm{W}$ & 11 & 54.60 & 8.58 & 15.7 & 0.00 & 54.60 & 99.75 & 4.2 \\
\hline $1256 \mathrm{D}-3$ & $6^{\circ} 44.1631^{\prime} \mathrm{N}$ & $91^{\circ} 56.0612^{\prime} \mathrm{W}$ & 8 & 33.80 & 5.54 & 16.4 & 0.00 & 33.80 & 86.00 & 3.6 \\
\hline $1256 \mathrm{D}-4$ & $6^{\circ} 44.1631^{\prime} \mathrm{N}$ & $91^{\circ} 56.0612^{\prime} \mathrm{W}$ & 6 & 24.00 & 1.31 & 5.5 & 0.00 & 24.00 & 78.25 & 3.3 \\
\hline $1256 \mathrm{D}-5$ & $6^{\circ} 44.1631^{\prime} \mathrm{N}$ & $91^{\circ} 56.0612^{\prime} \mathrm{W}$ & 4 & 5.30 & 0.53 & 10.0 & 0.00 & 5.30 & 53.50 & 2.2 \\
\hline 1256D-F1 & $6^{\circ} 44.1631^{\prime} \mathrm{N}$ & $91^{\circ} 56.0612^{\prime} \mathrm{W}$ & \multicolumn{6}{|c|}{ Fishing run 1 (9 inch fishing magnet with 2 junk baskets) } & 23.75 & 1.0 \\
\hline $1256 \mathrm{D}-\mathrm{F} 2$ & $6^{\circ} 44.1631^{\prime} \mathrm{N}$ & $91^{\circ} 56.0612^{\prime} \mathrm{W}$ & \multicolumn{6}{|c|}{ Fishing run 2 ( $91 \frac{1}{2}$ inch fishing mill with 2 junk baskets) } & 28.00 & 1.2 \\
\hline $1256 \mathrm{D}-\mathrm{F} 3$ & $6^{\circ} 44.1631^{\prime} \mathrm{N}$ & $91^{\circ} 56.0612^{\prime} \mathrm{W}$ & \multicolumn{6}{|c|}{ Fishing run 3 (91/2 inch fishing mill with 1 junk basket) } & 28.50 & 1.2 \\
\hline $1256 \mathrm{D}-\mathrm{F} 4$ & $6^{\circ} 44.1631^{\prime} \mathrm{N}$ & $91^{\circ} 56.0612^{\prime} \mathrm{W}$ & \multicolumn{6}{|c|}{ Fishing run 4 (9 inch fishing magnet with 2 junk baskets) } & 22.05 & 0.9 \\
\hline $1256 \mathrm{D}-6$ & $6^{\circ} 44.1631^{\prime} \mathrm{N}$ & $91^{\circ} 56.0612^{\prime} \mathrm{W}$ & 8 & 25.80 & 1.39 & 5.4 & 0.00 & 25.80 & 85.70 & 3.6 \\
\hline $1256 \mathrm{D}-7$ & $6^{\circ} 44.1631^{\prime} \mathrm{N}$ & $91^{\circ} 56.0612^{\prime} \mathrm{W}$ & 12 & 46.00 & 10.68 & 23.2 & 0.00 & 46.00 & 96.00 & 4.0 \\
\hline $1256 \mathrm{D}-8$ & $6^{\circ} 44.1631^{\prime} \mathrm{N}$ & $91^{\circ} 56.0612^{\prime} \mathrm{W}$ & 13 & 62.50 & 18.49 & 29.6 & 0.00 & 62.50 & 99.50 & 4.1 \\
\hline $1256 \mathrm{D}-\mathrm{T}$ & $6^{\circ} 44.1631^{\prime} \mathrm{N}$ & $91^{\circ} 56.0612^{\prime} \mathrm{W}$ & \multicolumn{6}{|c|}{ Logging run 1: triple combo tool string } & 24.25 & 1.0 \\
\hline $1256 \mathrm{D}-\mathrm{V}$ & $6^{\circ} 44.1631^{\prime} \mathrm{N}$ & $91^{\circ} 56.0612^{\prime} \mathrm{W}$ & \multicolumn{6}{|c|}{ Logging run 2: Vertical Seismic Instrument } & 26.00 & 1.1 \\
\hline $1256 \mathrm{D}-\mathrm{F}$ & $6^{\circ} 44.1631^{\prime} \mathrm{N}$ & $91^{\circ} 56.0612^{\prime} \mathrm{W}$ & \multicolumn{6}{|c|}{ Logging run 3: Formation MicroScanner } & 8.00 & 0.3 \\
\hline $1256 \mathrm{D}-\mathrm{U}$ & $6^{\circ} 44.1631^{\prime} \mathrm{N}$ & $91^{\circ} 56.0612^{\prime} \mathrm{W}$ & \multicolumn{6}{|c|}{ Logging run 4: Ultrasonic Borehole Imager } & 12.00 & 0.5 \\
\hline $1256 \mathrm{D}-\mathrm{F}$ & $6^{\circ} 44.1631^{\prime} \mathrm{N}$ & $91^{\circ} 56.0612^{\prime} \mathrm{W}$ & \multicolumn{6}{|c|}{ Logging run 5: Formation MicroScanner } & 12.00 & 0.5 \\
\hline \multirow[t]{3}{*}{$1256 \mathrm{D}-\mathrm{T}$} & $6^{\circ} 44.1631^{\prime} \mathrm{N}$ & $91^{\circ} 56.0612^{\prime} \mathrm{W}$ & \multicolumn{6}{|c|}{ Logging run 6: temperature tools (TAP/DLL/SGT) } & 18.50 & 0.8 \\
\hline & & Site 1256 totals: & 62 & 252.00 & 46.52 & 18.5 & 0.00 & 252.00 & 926.50 & 38.6 \\
\hline & \multicolumn{2}{|c|}{ Expedition 312 totals: } & 62 & 252.00 & 46.52 & 18.5 & 0.00 & 252.00 & 926.50 & 38.6 \\
\hline
\end{tabular}

Notes: Seafloor depth $=8645.4$ mbrf. TAP $=$ Temperature/Acceleration/Pressure tool, DLL = Dual Laterolog, SGT = Scintillation Gamma Ray Tool. 